\author{
UNIVERSIDADE DE SÃO PAULO - USP \\ FACULDADE DE FILOSOFIA, LETRAS E CIÊNCIAS HUMANAS \\ DEPARTAMENTO DE GEOGRAFIA \\ PROGRAMA DE PÓS-GRADUAÇÃO EM GEOGRAFIA HUMANA
}

\title{
Turismo de Segunda Residência em Praia Grande (SP)
}

\author{
Imário Vieira
}

São Paulo

2008 


\title{
UNIVERSIDADE DE SÃO PAULO - USP \\ FACULDADE DE FILOSOFIA, LETRAS E CIÊNCIAS HUMANAS \\ DEPARTAMENTO DE GEOGRAFIA \\ PROGRAMA DE PÓS-GRADUAÇÃO EM GEOGRAFIA HUMANA
}

\section{Turismo de Segunda Residência em Praia Grande (SP)}

\author{
Imário Vieira
}

Dissertação apresentada ao Programa de PósGraduação em Geografia Humana do Departamento de Geografia da Faculdade de Filosofia, Letras e Ciências Humanas da Universidade de São Paulo para obtenção do título de Mestre, sob a orientação do Prof. Dr. Júlio César Suzuki.

São Paulo

2008 
AUTORIZO A REPRODUÇÃO E DIVULGAÇÃO TOTAL OU PARCIAL DESTE TRABALHO, POR QUALQUER MEIO CONVENCIONAL OU ELETRÔNICO, PARA FINS DE ESTUDO E PESQUISA, DESDE QUE CITADA A FONTE.

Serviço de Biblioteca e Documentação da Faculdade de Filosofia, Letras e Ciências Humanas da Universidade de São Paulo

FICHA

CATALOGRÁFICA

V658 Vieira, Imário

Turismo de segunda residência em Praia Grande (SP) / Imário

Vieira; orientador Júlio César Suzuki. - São Paulo, 2008.

221 f. ; il. : maps. : fots.

Dissertação (Mestrado - Programa de Pós-Graduação em Geografia Humana. Área de concentração: Geografia Humana) - Departamento de Geografia da Faculdade de Filosofia, Letras e Ciências Humanas da Universidade de São Paulo.

1. Turismo - Aspectos urbanísticos - Praia Grande (SP).

2. Residências secundárias - Praia Grande (SP). 3. Urbanização - História - Praia Grande - São Paulo (SP). 4. Desenvolvimento turístico - Praia Grande (SP). 5. Turismo litorâneo - Praia Grande (SP). I. Título. 


\section{DEDICATÓRIA}

Em especial, dedico este trabalho de pesquisa à minha querida e tão amada "mãezona", D. Terezinha; mulher forte, de fibra e batalhadora que me deu a vida, amor, carinho e atenção e da qual herdei a garra para buscar os meus ideais de vida.

Também dedico ao meu pai (in memória), que mesmo não estando fisicamente ao meu lado, foi um motivador para que eu não desistisse desse sonho.

Dedico este trabalho às minhas irmãs Íris e Irene, sobrinhas Soraya e Geiris e, finalmente, à minha sobrinha-neta Beatriz Vieira Benevides Brito.

Ainda, ao meu professor, orientador e amigo, Prof. Dr. Júlio César Suzuki, aos meus irmãos e melhores amigos, Dr. Gustavo Raul Silva Martinez, Claudino Mayer, Luiz Carlos Fiorezzi. E a outros três amigos muito especiais, Dra. Luciana Girard, Adriana Raquel Silva Martinez e Alberto Raul Gazzo.

E por fim, dedico este trabalho a Deus, pois sem ele nada disso seria possível e a todos àqueles que, de alguma forma, contribuíram para a realização deste meu trabalho de pesquisa científica. 


\section{AGRADECIMENTOS}

Qualquer trabalho científico exige muito do autor e pesquisador, mas como tal, não estamos sós nessa jornada, pois são muitos aqueles que contribuíram para chegarmos até este ponto. É preciso, portanto, destacar estas importantes participações, as quais sem elas, seria difícil a conclusão de tal trabalho de pesquisa. Agradeço a todas as pessoas com as quais tive o prazer da convivência durante as minhas pesquisas: alunos, colegas de trabalho, amigos, instituições e aos funcionários públicos da prefeitura de Praia Grande, Santos e São Vicente. Contudo, algumas pessoas são e foram de fundamental importância para este meu trabalho de pesquisa, a estas pessoas, o meu agradecimento nominal se faz necessário.

Com muito louvor, os meus sinceros agradecimentos, admiração e respeito ao meu ilustríssimo professor, orientador e amigo Prof. Dr. Júlio César Suzuki pela sua grande atenção, dedicação, orientação e conselhos valorosos, que foram significativos para a realização deste trabalho.

Aos membros da banca de qualificação, Prof ${ }^{a}$ Dra. Claudette Barriguela Junqueira e Prof ${ }^{a}$ Dra. Mônica Arroyo, cujas observações, críticas e sugestões muito enriqueceram este trabalho.

Aos professores das disciplinas cursadas, e pelos conhecimentos imprescindíveis que obtive e que foram de primordial importância na elaboração e na conclusão deste trabalho: as professoras Dra. Lígia F. Ferreira, Dra. Rita de Cássia Arriza da Cruz, Dra. Beatriz P. Siqueira Bueno, Dra. Maria Mônica Arroyo e aos professores Dr. Julio César Suzuki, Dr. Nestor Goulart Reis Filho e Dr. Murillo Marx.

Meu muito obrigado a minha querida mãe, Dona Terezinha, por estar sempre presente em minha vida, por me apoiar e dar tanto suporte, me incentivando e encorajando a andar a segunda milha e aos meus irmãos, irmãs, cunhadas(os), sobrinhas(os) e parentes de um modo geral pelo apoio e incentivo.

Ao meu grande irmão, Dr. Gustavo Raul Silva Martinez, que tem sido para mim mais que um irmão e amigo, tem sido meu braço forte, meu apoio, meu 
grande incentivador, pois, sem ele, eu não poderia ter realizado os meus trabalhos de campo em Praia Grande. E agradeço ainda, aos meus melhores e grandes amigos, o professor e doutorando Claudino Mayer, por sua sabedoria, seus conselhos e diretrizes, pois sua participação foi essencial para minha entrada na USP e o Professor Luiz Carlos Fiorezzi, por sua grande amizade, conselhos e incentivos. E não poderia esquecer de uma amiga super especial, Dra. Luciana Girard, pelo apoio e carinho. Essas quatro pessoas têm sido um presente de Deus e de grande ajuda em minha vida, tanto nos momentos difíceis, como nos de alegria. A eles, os meus sinceros agradecimentos.

Meu muito obrigado a Seção de Patrimônio Histórico de Praia Grande, em especial, às professoras Mônica Solange Rodrigues, Magna Flora Calis, Maria Cristina Roising, Sandra Lúci G. de Azevedo, Roseli Geremello e aos professores Sérgio Luiz C. Dias e César Augusto T. Casasco por sua cordial atenção, profissionalismo, e sobretudo, pelo carinho que tiveram com minha pessoa nas vezes que precisei visitá-los. Também, não poderia deixar de agradecer às Secretarias da Cultura, do Meio Ambiente, de Turismo (Sra. Neusa Maria da Silva Arbia), Obras Públicas e de Planejamento da Estância Balneária de Praia Grande. Ainda, aos funcionários do Outeiro de Santa Catarina na cidade de Santos, Centro Histórico de São Vicente, à Dona Circe Sanchez Toschi e outros.

O meu muito obrigado aos colegas do grupo de colóquio e orientandos do Prof. Dr. Júlio César Suzuki por suas colaborações e sugestões.

A minha amiga Hilda Porto Gambarotto e funcionários do IBGE, EMPLASA, SEADE, SABESP, DERSA, EMBRATUR e Secretaria Municipal do Desenvolvimento Urbano e Meio Ambiente de Santos. E também ao IGC, em especial, a funcionária Helena Takenouchi e ao Geógrafo Rinaldo Pinho pela elaboração de alguns mapas dessa dissertação.

Também agradeço à minha colega e amiga Professora Cristiane Gregorin pela revisão da língua portuguesa e aos meus amados(as) alunos(as) das faculdades e universidades que leciono ou lecionei, pois sempre estiveram ao meu lado, torcendo e incentivando-me nesta jornada de estudos e reflexões. 
Enfim, o meu agradecimento a todos com os quais vivi, convivi, vi, li, ouvi e aprendi e que, de certa forma, me ajudaram direta ou indiretamente para a elaboração e conclusão deste trabalho acadêmico-científico. 
"A Praia Grande tem uma largura de duzentos metros e a água dá pé até bem longe, onde as vagas arrebentam encrespando-se as vezes. A natureza e os hábitos que ela forma são tão dominantes que a grande afluência de excursionistas até hoje não conseguiu perturbar a deliciosa serenidade da pesca, na qual juntas de bois tomam parte puxando as redes. Correm os carros sobre a areia pela Praia Grande a qualquer velocidade e tão despreocupados os automobilistas que, quando sobe a maré, vêem-se em apuros para desatolá-los nos pontos em que e necessário aventurar-se mar adentro, a fim de evitar os barrancos dos riachos maiores. A ingênua inexperiência do homem da cidade proporciona então uma entrada aos praianos, organizados em equipes de socorro".

GUIMARÃES, Mário. São Paulo, quatro séculos de luta. Rio de Janeiro: Vitória, 1954, p 52.

"Se não houver frutos, valeu a beleza das flores; Se não houver flores, valeu as sombras das folhas; Se não houver folhas; valeu a intenção da semente".

(De autor desconhecido) 
VIEIRA, Imário. Turismo de segunda residência em Praia Grande, SP. São Paulo, 2008, 230 f. Dissertação (Mestrado em Geografia Humana) - Faculdade de Filosofia, Letras e Ciências Humanas, Universidade de São Paulo.

\section{RESUMO}

A presente dissertação analisa o fenômeno do turismo de segunda residência sob o prisma da geografia humana e histórica da cidade de Praia Grande e sua inserção no turismo, produção do espaço e segunda residência.

O objetivo desta pesquisa é o de analisar o processo histórico da urbanização de Praia Grande, desde a época em que ainda fazia parte de São Vicente e entender como se deu a produção do espaço amparada pelo turismo de segunda residência.

O procedimento metodológico utilizado procurou entender os fatos, as políticas públicas e as ações que levaram às transformações, crescimento e desenvolvimento de Praia Grande do início do século passado até os dias atuais.

Os resultados desta pesquisa mostram como se deu a descoberta da atividade turística desta estância balneária, pertencente à Região Metropolitana da Baixada Santista (RMBS), que vem despertando o interesse dos mais variados segmentos da sociedade, sejam eles, das áreas da construção civil, planejamento, investimentos, comércio, dentre outros. Por conta disso, constatamos um abrupto crescimento e desenvolvimento desta estância balneária com mudanças paisagísticas e investimentos na sua infra-estrutura, que em seu bojo, trouxeram mais recursos e investimentos para esta cidade média paulista.

PALAVRAS CHAVE: Praia Grande, turismo de segunda residência, turismo litorâneo, produção do espaço, turismo e urbanização em Praia Grande, SP. 
VIEIRA, Imário. Turismo de segunda residência em Praia Grande, SP. São Paulo, 2008, 230 f. Dissertação (Mestrado em Geografia Humana) - Faculdade de Filosofia, Letras e Ciências Humanas, Universidade de São Paulo.

\section{ABSTRACT}

The present dissertation analyses the phenomenon of tourism of second residency under the prism of Human Geography and the history of the city of Praia Grande and its insertation in tourism, production of space and second residency.

The main purpose of this research is to analyze the historic process of Praia Grande's urbanization since the time it was still a neighborhood of São Vicente and understand how the production of space has occurred supported by the second residency.

The methodological procedure used has searched to understand the facts, public politics and actions that led this city to transformation, growing and development since the beginning of last century until today.

The results of this research has shown how tourism activity appears in this city, which is part of the Metropolitan Region of Baixada Santista (RMBS) that nowadays is being the target of many segments of the society such as civil construction, planning, investment, business and other ones. In this way, we have verified an abrupt growing and development of this city with paisagistic' changes and improvements in its infra-structure that all together brought new resources and investments to this paulistan medium sized city.

KEY WORDS: Praia Grande, tourism of second residency, sea shore tourism, paisagistic' changes, production of space, tourism and urbanization in Praia Grande, SP. 
VIEIRA, Imário. Turismo de segunda residencia em Praia Grande, São Paulo, SP, 2008, 230 f. Disertación (Maestria em Geografia Humana) - Facultad de Filosofía y Ciencias Humanas, Universidad de São Paulo.

\section{RESUMEN}

La presente disertación analiza el fenómeno del turismo de segunda residencia bajo el prisma de la geografia humana e histórica de la ciudad de Praia Grande, y su inserción en el turismo, producción del espacio y segunda residencia.

El objetivo de esta investigación es el de analizar el proceso histórico de la urbanización de Praia Grande, desde la época em que aún era parte de São Vicente, y entender como se dió la producción de espacio amparada por el turismo de segunda residencia.

El procedimiento metodológico utilizado buscó entender los hechos, las políticas públicas y las acciones que llevaran a las transformaciones, crecimiento y desarrollo de Praia Grande desde el inicio del siglo pasado hasta los dias actuales.

Los resultados de esta investigación muestran como se dió la descubierta de la actividad turística de esta estancia balneária, perteneciente a la región metropolitana de la Baixada Santista (RMBS), que viene despertando el interés de los mas variados segmentos de la sociedad, sean de las áreas de construcción civil, planeamiento, inversiones, comercio, entre otros. Por esto, constatamos um abrupto crecimiento y desarrollo de esta estancia balneária com cambios paisagísticos e inversiones em su infraestructura, que em su bulto, trajeran más recursos e inversiones para esta mediana ciudad paulista.

PALABRAS CLAVES: Praia Grande, turismo de segunda residencia, turismo litoraleño, producción del espacio, turismo y urbanización en Praia Grande, SP 
SUMÁRIO

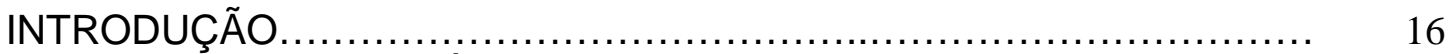

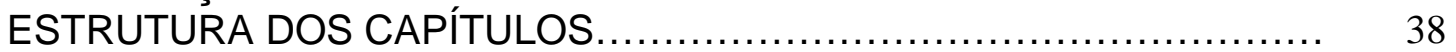

CAPÍTULO I - RESGATE DA HISTÓRIA DA ESTÂNCIA BALNEÁRIA

DE PRAIA GRANDE................................................................... $\quad 40$

1.1 - Ligação do litoral com o planalto paulista......................................... 41

1.2 - Início da ocupação........................................................ 45

1.3 - Ocupação mais recente.............................................. 55

1.4 - O sítio urbano em Praia Grande e as regiões metropolitanas........... $\quad 70$

CAPÍTULO II-TURISMO, SUAS ORIGENS E A EXPLORAÇÃO IMOBILIÁRIA..................................................................................

2.1 - O turismo litorâneo e o banho de mar............................................... 83

2.2 - O início da atividade turística em Praia Grande............................... $\quad 86$

2.3 - A segunda residência no crescimento urbano de Praia Grande......... $\quad 91$

2.4 - O tecido urbano na primeira metade do século passado................... 106

2.5 - A nova forma urbana e o incremento da população.......................... 110

CAPÍTULO III - ESPECIFICIDADES DA URBANIZAÇÃO E DA

SEGUNDA RESIDÊNCIA............................................................. 137

3.1 - Sua emancipação política e a urbanização........................................ 138

3.2 - Uma grande expansão urbana e o aumento da população................ 141

3.3 - A população de Praia Grande e sua parcela mais carente................ 163

3.4 - Os impactos ambientais e a qualidade de Praia Grande como 173

estância balneária.

3.5 - O Novo tecido urbano de Praia Grande.

3.6 - Plano diretor e a lei de ordenamento do uso, da ocupação e do

parcelamento do solo.

3.7- O Turismo de segunda residência e principais atrativos turísticos de

Praia Grande.

CONSIDERAÇÕES FINAIS.................................................................... 209

REFERÊNCIAS ............................................................ 222

FONTES DE IMAGENS DAS PÁGINAS DE ABERTURA DA CAPA,

INTRODUÇÃO, CAPÍTULOS E CONCLUSÃO............................................ 228

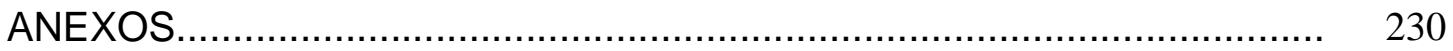




\section{LISTA DE FIGURAS}

Figura 01 - São Paulo de Piratininga em 1600.

Figura 02 - Ligação entre a Ponte Pênsil e a Fortaleza do Itaipu (final da década de 1920).

Figura 03 - Planta do Sítio de Praia Grande.

Figura 04 - Regiões Metropolitanas, aglomerados e microrregiões do estado de São Paulo.

Figura 05 - Propaganda do Hotel dos Alemães (frente).......................... $\quad 90$

Figura 06 - Propaganda do Hotel dos Alemães (verso)........................... $\quad 92$

Figura 07 - Propaganda do Jardim Guilhermina..................................... 101

Figura 08 - Empreendimentos imobiliários de Praia Grande na segunda metade da década de 1920

Figura 09 - Propaganda do Balneário Flórida.

Figura 10 - Propaganda do Jardim Mathilde (frente).....

Figura 11 - Propaganda do Jardim Mathilde (verso)

109

Figura 12 - Anúncio do Prédio Xixová.

Figura 13 - Anúncio do Prédio Shangri-lá.....

Figura 14 - Propaganda do Conjunto Habitacional Cidade Ocian (frente).

Figura 15 - Propaganda do Conjunto Habitacional Cidade Ocian (verso)..

\section{LISTA DE FOTOS}

Foto 01 - Ponta de Jurubatuba, 1a Bateria, inaugurada em 1903............. 33

Foto 02 - Vista aérea de Solemar na década de 70............................... 34

Foto 03 - Vista aérea do antigo Sítio Prainha............................................ 43

Foto 04 - Maria Pacheco Nobre com seus alunos no início do Séc. XX... 56

Foto 05 - Ponte Pênsil em 1914............................................................. 58

Foto 06 - Estradinha que liga a Ponte Pênsil a Praia Grande - maio de 1928.

Foto 07 - Ruínas da primitiva Capela de Santo Antonio do Boqueirão...... 59

Foto 08 - Capela de Santo Antonio do Boqueirão..................................... 60

Foto 09 - Capela de Santo Antonio do Boqueirão em 24/03/2007............... 60

Foto 10 - Pescadores em Praia Grande do início do Século XX .............. 65

Foto 11 - Pescadores em Praia Grande em maio de 1928.......................... 66

Foto 12 - Poço artesiano e reservatório de água do Jardim Guilhermina.. $\quad 67$

Foto 13 - Comemoração da inauguração da energia elétrica em 1926.... 69

Foto 14 - Sítio urbano da Estância Balneária de Praia Grande................. 73

Foto 15 - Inauguração do Hotel dos Alemães construído em 1928.......... 87

Foto 16 - Hotel dos Alemães e suas cabines de banho em 1928............. 88

Foto 17 - Foto aérea do loteamento do Jardim Guilhermina em 1928...... 99 
Foto 18 - Olaria do Jardim Guilhermina............................................... 100

Foto 19 - Foto aérea do loteamento do Jardim Flórida em 1946.............. 104

Foto 20 - Moradia de madeira - Praia Grande na primeira metade do

Sec.XX

111

Foto 21 - Moradia de madeira - Praia Grande na primeira metade do

Sec.XX

111

Foto 22 - Moradia de madeira em Praia Grande nos dias atuais.............. 112

Foto 23 - Moradia de madeira em Praia Grande nos dias atuais.............. 112

Foto 24 - Restaurante Lagosta........................................................... 115

Foto 25 - Loteamento do Jardim Mathilde em fevereiro de 1947.............. 116

Foto 26 - Loteamento do Jardim Mathilde em março de 1947.................. 117

Foto 27 - Avenida Beiramar................................................................. 120

Foto 28 - Via Anchieta logo após a sua inauguração em 1947.................. 129

Foto 29 - Edifício do final da década de 1960....................................... 133

Foto 30 - Região central com poucos prédios acima de 04 andares......... 134

Foto 31 - Vista aérea do Conjunto Habitacional Cidade Ocian em 1955... 144

Foto 32 - Reurbanização da Interligação da Av. Beiramar........................ 153

Foto 33 - Reurbanização da Avenida Costa e Silva................................. 154

Foto 34 - Reurbanização da Avenida Costa e Silva................................. 154

Foto 35 - Reurbanização da Avenida Costa e Silva................................. 155

Foto 36 - Espaço Conviver - Boqueirão................................................. 156

Foto 37 - Centro de Informações (CITM) de Praia Grande, SP............... 156

Foto 38 - Prédios Residencial Copacabana e Pégasus com mais de $20 \quad 158$

andares

Foto 39 - Avenida Presidente Kennedy lotada de ônibus - Década de 1970.

Foto 40 - Lixo na praia - Boqueirão.

Foto 41 - Vista parcial da orla marítima de Praia Grande......................... 194

Foto 42 - Calçadão e ciclovia de Praia Grande........................................ 195

Foto 43 - Quiosques modernizados......................................................... 196

Foto 44 - Aluguel de Carrocelas - Boqueirão............................................ 197

Foto 45 - Vista parcial da Área de Lazer Ézio Dall'Acqua (o Portinho)...... 198

Foto 46 - Estátua de Netuno no Ocian....................................................... 199

Foto 47 - Praça Integração dos Bairros, "Praça das Bolas" no bairro Tupi 199

Foto 48 - Praça da Paz (das cabeças)................................................... 200

Foto 49 - Show de verão em Praia Grande............................................ 203

\section{LISTA DE GRÁFICOS}

Gráfico 01 - Local de trabalho ou onde trabalhou por último..................... 77

Gráfico 02 - Procedência dos turistas em Praia Grande, SP................... 78

Gráfico 03 - O que é pior com os turistas............................................. 160

Gráfico 04 - Local de procedência antes de viver em Praia Grande, SP... 165

Gráfico 05 - Renda familiar - Lado direito/esquerdo da SP-55................. 167

Gráfico 06 - Nível de escolaridade - Lado direito e esquerdo da SP-55... 168 
Gráfico 07 - Qual a sua profissão - Lado direito e esquerdo da SP-55..... 169

Gráfico 08 - O que acha da balneabilidade - Lado dir/esq da SP-55........ 176

Gráfico 09 - O que acha da balneabilidade - Turistas........................... 177

Gráfico 10 - Nota para a sujeira das praias - Lado dir/esq da SP-55........ 181

Gráfico 11 - Nota para a sujeira das praias - Turistas............................. 182

Gráfico 12 - Nível de escolaridade dos turistas....................................... 191

Gráfico 13 - Renda Familiar dos turistas que visitam Praia Grande.......... 192

\section{LISTA DE TABELAS}

Tabela 01 - População Rural e Urbana da Estância Balneária de Praia Grande segundo os Censos do IBGE de 1950-2000.

Tabela 02 - Domicílios Urbanos Recenseados por Espécie e Condição de Ocupação, segundo os Censos do IBGE de 1991-2000...................... 149

Tabela 03 - Local de procedência antes de viver em Praia Grande, SP.... 164

Tabela 04 - Ancestrais caiçaras/pescadores em Praia Grande, SP.......... 172

Tabela 05 - O que deve ser melhorado em Praia Grande - Turistas.......,.. 193

Tabela 06 - Infra-estrutura hoteleira da Praia Grande em 2001/2008....... 204

\section{LISTA DE MAPAS}

Mapa 1 - Localização da Estância Balneária de Praia Grande............. 72

Mapa 2 - A Estância Balneária de Praia Grande e suas ligação

rodoviária com a Metrópole de São Paulo.

Mapa 3 - Sítio urbano de Praia Grande............................................ 76

Mapa 4 - São Vicente antes da emancipação de Praia Grande em 1967.. 140

Mapa 5 - Expansão urbana................................................................... 148

Mapa 6 - Domicílio de uso ocasional.................................................. 152

Mapa 7 - Densidade residencial por setor censitário 2000....................... 162 
INTRODUÇÃO

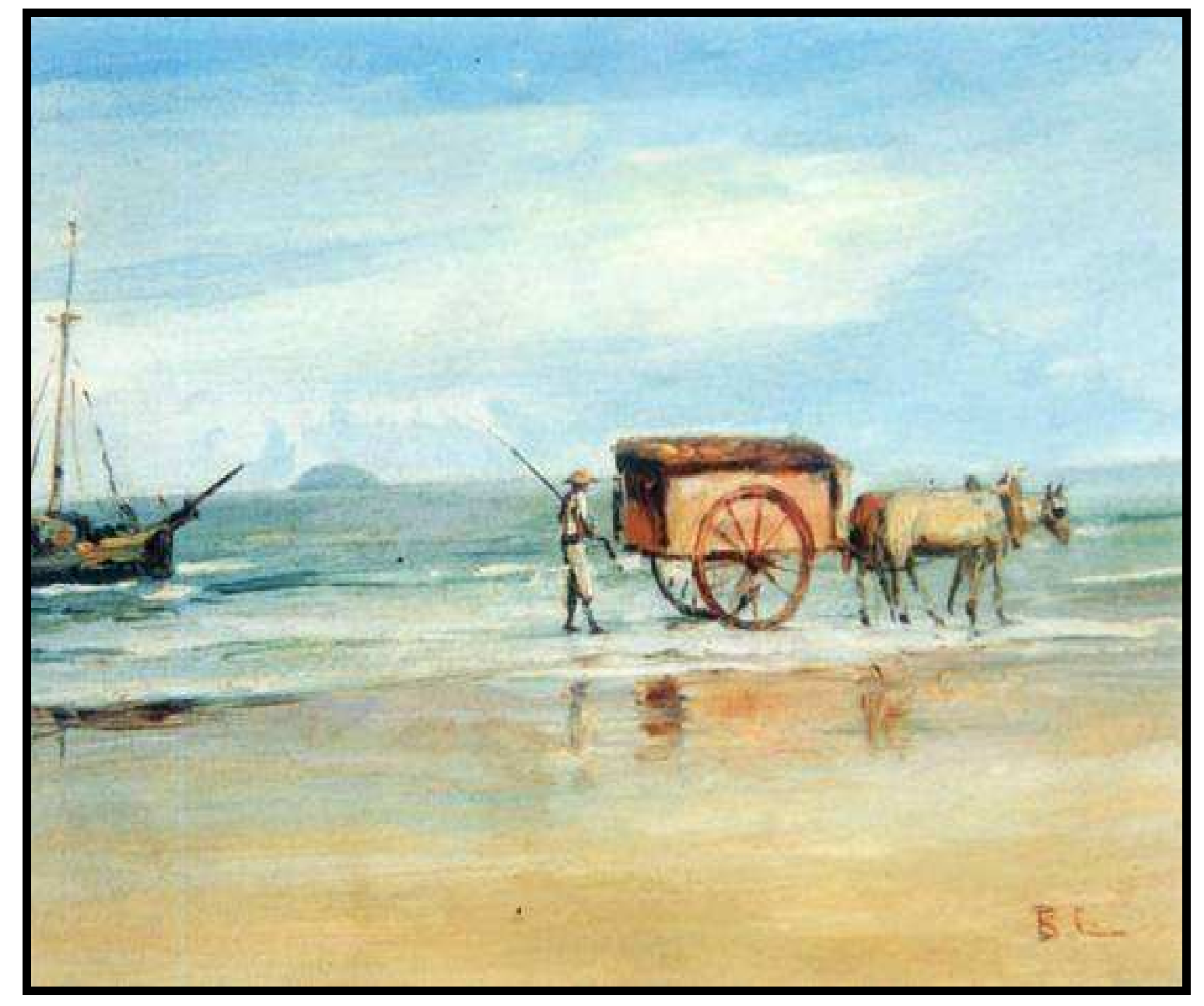


A realização desta pesquisa, demandou uma verdadeira peregrinação à Estância Balneária de Praia Grande e aos vários órgãos públicos municipais, estaduais e federais. $O$ presente trabalho expressa uma pequena parte de um conjunto de reflexões que vêm sendo realizada há algum tempo.

Foi a paixão pela Geografia Humana que fez surgir o interesse em estudar a estância balneária de Praia Grande, sua história e o processo de urbanização ${ }^{1}$, retratando a produção do espaço amparado pelo turismo de segunda residência.

Santos (1996) em uma de suas várias definições do espaço, diz:

"O espaço é formado por um conjunto indissociável, solidário e também contraditório, de sistemas de objetos e sistema de ações, não considerados isoladamente, mas como o quadro único no qual a história se dá" (Santos, 1996, p. 51).

Mais adiante, ele afirma:

"O espaço geográfico deve ser considerado como algo que participa igualmente da condição do social e do físico, um misto, um híbrido" (Santos, 1996, p. 70).

Assim, para compreendermos esse espaço, precisamos entender esse conjunto de ações, esses sistemas de objetos criados pelo homem, aos quais, como um produto social das relações desse homem com o meio físico, vão causando modificações nesse espaço com o passar do tempo.

Para nós, entendermos essa produção do espaço passa a ser fundamental para a compreensão das transformações ocorridas no espaço natural ${ }^{2}$ dessa

\footnotetext{
1 Davis (1977, p. 14) define urbanização como sendo "a proporção da população concentrada em estabelecimentos urbanos ou o crescimento dessa proporção". Ele diz ainda que o processo de urbanização "seria, portanto, a passagem de uma forma menos densa e mais espalhada de distribuição da população no espaço para uma forma concentrada em centros urbanos".

Ao falar do surgimento da urbanização no Brasil, Serra (1987, p. 18) diz que ela inicia-se em nosso país em 1532, com a implantação do regime de capitanias e com a fundação de São Vicente, município ao qual Praia Grande pertenceu até 1967.
} 
cidade-média paulista do princípio do século passado para cá, quando ainda era um distrito de São Vicente. Esse processo de transformação do espaço que foi ocorrendo desde o princípio do Século XX, não só impôs novos modos de apropriação do espaço por meio do estabelecimento de novos usos, como também, permitiu o processo de valorização do solo urbano por meio dos investimentos em infra-estrutura implantada pelos agentes públicos e privados.

Para possibilitar-nos o entendimento sobre a história e o processo de urbanização da Estância Balneária de Praia Grande, torna-se necessária a compreensão sobre a apropriação e a produção do espaço, sua forma e adaptações que foram ocorrendo ao longo dos anos, os agentes da construção civil e seu papel em todo o processo de transformação e urbanização. Para isso, utilizamos Davis (1977), Lee (1998), Marx (1988,1991), Santos (1980, 1996, 2001, 2004, 2005), Serra (1987) e Suzuki (1996).

Ainda, para entendermos como se deu esta produção do espaço em Praia Grande, devemos observá-la dentro de um contexto mais regional, buscando como se dá a relação dessa estância com a metrópole de São Paulo e as regiões metropolitanas de nosso estado desde os primórdios de sua história.

Dentro do contexto da metropolização, buscamos Souza (1984 e 1999), que em seus livros sobre "A identidade da Metrópole" e "Metrópole e Globalização: conhecendo a cidade de São Paulo", aborda esses assuntos. Também buscamos, Carlos e Oliveira (2004), organizadores do livro, "Geografias de São Paulo, a metrópole do século XXI", que nos deram embasamento teórico das pesquisas realizadas sobre a metrópole, contando com uma reunião de inúmeros pesquisadores que dissertam a respeito de São Paulo, abordando

\footnotetext{
${ }^{2}$ Nas suas análise sobre o espaço, Serra (1987, p. 29) define espaço natural ou espaço físico natural como sendo a porção do espaço, quando se refira "a uma parte da superfície da Terra que não tenha ainda sofrido qualquer adaptação pela ação humana. Em oposição, chamar-se-á espaço físico adaptado, ou simplesmente espaço adaptado, uma parte da superfície de terra que já sofreu modificações pela ação humana". Já na visão de Santos (1980, p. 128) ele vê esse espaço adaptado como "produzido pela ação do homem". Assim, segundo Serra (1987, p. 50), essas adaptações que ocorrem no espaço "são, portanto, conscientes e dirigidas para determinada finalidade (...)". Ou ainda, "as adaptações no espaço são formas construídas para atender a certas necessidades sociais, geradas pelas relações sociais, que são, por sua vez, dinâmicas" (Serra, 1987, p. 73). No caso de Praia Grande, para atender a prática social do Turismo.
} 
questões sobre o seu crescimento e urbanização. Dentro desse contexto, foi importante a compreensão do papel e da influência da metrópole de São Paulo, como pólo gerador de riquezas e de atração de capital, pois ela acaba, de certa forma, influenciando o processo de crescimento e urbanização dos seus entornos ou regiões próximas à mesma, em especial, as zonas costeiras paulistas. Em relação a esta influência da metrópole nas zonas costeiras paulistas, Afonso (2006, p. 169) nos relata que "a zona costeira paulista é parte da área de influência da região metropolitana de São Paulo, integrando-se social e economicamente a ela".

Assim, esse estudo sobre a metrópole, possibilitou-nos uma maior compreensão do processo de urbanização das zonas costeiras paulistas, as quais, tem seu crescimento e o processo de urbanização influenciados pelas metrópoles.

Essa proximidade, da Estância Balneária de Praia Grande, com a metrópole de São Paulo tem influenciado o seu processo de urbanização e crescimento devido a sua integração social e econômica com a mesma por meio do fácil acesso com este pólo de concentração econômica. Arroyo (2004, p. 88) nos relata que:

"A metrópole de São Paulo afirma sua primazia concentrando os pólos de poder e direção do capital industrial e financeiro e de uma série de atividades relacionadas ao setor terciário superior fundamentais para a direção do processo de reprodução do capital em geral".

Sendo assim, a metrópole de São Paulo, marcada pela sua importância como pólo de poder e direção do capital, acaba induzindo à transferência de capital para outras regiões permitindo um processo de reprodução de capital, viabilizando a produção de bens e serviços, circulação, distribuição, troca e consumo. No entanto, nessa fase de reprodução do capital, entre os setores ligados à atividade terciária, temos as atividades ligadas ao veraneio, as quais com a flexibilização do sistema de transportes e facilidades de acesso, tornam as regiões litorâneas próximas à metrópole de São Paulo atrativas para receberem 
este capital e dinamizando seu crescimento e economia local. Nesse sentido, Afonso (2006, p. 169) nos informa que:

\begin{abstract}
"o incremento no processo de urbanização costeiro tem ocorrido principalmente nas faixas litorâneas próximas às metrópoles ou grandes cidades costeiras (...) impulsionado pela industrialização e pela expansão das atividades de veraneio (...). Assim, as faixas litorâneas próximas aos grandes centros urbanos costeiros ou que estão sob a influência das metrópoles interiores, como é o caso do litoral paulista em relação a São Paulo, tiveram sua paisagem rapidamente transformada pela expansão das áreas urbanas com a abertura de loteamentos turísticos ou novos loteamentos residenciais, a construção de indústrias e verticalização das áreas centrais ou orlas litorâneas".
\end{abstract}

Assim, a proximidade de regiões litorâneas, com grandes centros urbanos costeiros, ou sob a influência das metrópoles interiores, como a de São Paulo, passam a ter sua paisagem rapidamente transformada. Estas transformações têm ocorrido pela expansão de suas áreas urbanas, devido à facilidade de acesso, aos loteamentos turísticos ou novos loteamentos residenciais, ou até mesmo, com a verticalização de suas áreas centrais, ou de suas orlas litorâneas, como tem sido o caso da Estância Balneária de Praia Grande.

A Estância Balneária de Praia Grande, após os nossos levantamentos, teve sua paisagem transformada por meio da influência de dois agentes de transformação: o da iniciativa privada, representado pela indústria da construção civil, que por sua vez tem criado novos loteamentos, mudado a forma urbana e verticalizado o seu espaço e também por meio de um outro agente transformador, a administração pública desta estância. No entanto, nas últimas duas décadas, Praia Grande tem investido, cada vez mais, em infra-estrutura para atender aos grandes fluxos de turistas que para lá se dirigem aos finais de semana, férias e feriados.

Cabe-se ressaltar que, o fácil acesso, também ajuda a dinamizar estas mudanças, despertando o interesse de seus visitantes em adquirir imóveis na região litorânea e movimentando a economia local. Afonso (2006, p. 203) nos informa que "a proximidade da metrópole de São Paulo e a acessibilidade proporcionada pelas rodovias asfaltadas têm definido a localização dos 
empreendimentos imobiliários voltados ao lazer do paulistano". Desta forma, a proximidade e a mobilidade proporcionada pelas rodovias de acesso entre a metrópole e seus entornos, tem sido um outro fator de valorização dessas áreas para o lazer paulistano. Neste sentido, Praia Grande tem posição privilegiada, pois a nova pista descendente da Rodovia dos Imigrantes desemboca quase que diretamente nesta estância balneária, permitindo um rápido e fácil acesso ao lazer e atraindo empreendimentos imobiliários para a região.

Entre as mais variadas formas de lazer para o paulistano está o turismo litorâneo. Dentre os trabalhos que pesquisamos neste tema, destacamos as contribuições de Lee (1998) e Oliveira (1998) cujos estudos e levantamentos buscaram compreender a organização do espaço no litoral catarinense e paulista, mostrando as especificidades de cada um e analisando as transformações do rural para o urbano ligadas à especulação imobiliária da segunda residência e ao fenômeno do turismo litorâneo. Temos, ainda, as abordagens de Seabra (1979), que centrou sua discussão sobre o fenômeno de segunda residência na cidade de Santos, discutindo o processo de valorização do espaço, que ocorreu com o processo de verticalização destinada à segunda residência e ao lazer litorâneo. Outra autora pesquisada foi Afonso (2006), que buscou entender a paisagem, a urbanização e as transformações que têm ocorrido na baixada santista e que, muitas vezes, se reproduzem em outras áreas litorâneas de nosso estado e país, cujas transformações, em sua grande maioria, influenciadas pelas atividades turísticas e sob a intervenção dos agentes públicos e privados, transformam a paisagem local. Assim, o contato com estes trabalhos nos forneceu subsídios para pensar a produção do espaço na Estância Balneária de Praia Grande.

Portanto, o litoral de algumas estâncias balneárias tem se constituído, cada vez mais, como um atrativo para as atividades do turismo e da construção civil e dentre os seus mais variados usos, dentro da construção civil, estão aqueles destinados à segunda residência. Lee (1998, p. 1) complementa dizendo:

"O litoral brasileiro, se constitui cada vez mais em espaços, que podem se tornar excelentes atrativos para a atuação de atividades como a construção civil e o turismo. O uso destas áreas para tais fins, pressupõe todo um contexto de transformações, cuja principal característica reside na 
incorporação de novos elementos, até então estranhos a estas paisagens. Neste processo o uso do solo e a forma de ocupação também são transformados".

Vemos isso que a autora nos fala, retratado em Praia Grande, pois foram inúmeras as obras de transformação da paisagem e melhoramentos urbanos promovidos pelas sucessivas gestões municipais em sua orla marítima e adjacências. Estas mudanças fizeram de Praia Grande, uma estância balneária cada vez mais atrativa para a atividade turística, para a indústria da construção civil, e o seu uso, para tais fins, pressupõe mudanças na paisagem do lugar. Desta forma, como diz Deus (2002, p. 39), no estudo do espaço, há uma tendência de privilegiar a forma. Ele nos diz:

\begin{abstract}
"No estudo do espaço, há uma tendência de privilegiar a forma, sabendo que além de ser a primeira impressão da paisagem, é ainda sua parte predominante. (...) Para fazermos uma análise do espaço com eficácia, devemos penetrar na paisagem - fenômeno - na busca da sua essência. Os objetos que, no seu conjunto, formam a paisagem têm conteúdo, porém tal conteúdo não se define aparentemente pela essência, mas pelas condições que o permitiram permanecer como forma, dentro de uma determinada função fixada pela sociedade. Como a sociedade não está parada, mas em movimento, o que é estável não é a forma - a paisagem mas a sua essência. Então, a paisagem muda a todo instante em que a sociedade necessitar, ou seja, a paisagem muda conforme a intencionalidade dos grupos sociais".
\end{abstract}

Sendo assim, com bases nas considerações feitas por Lee $(1998$, p. 1) e Deus (2002, p. 39), essas mudanças que vemos materializadas no espaço por meio da paisagem visaram consolidar a cidade de Praia Grande como uma importante e moderna estância balneária e ela muda a todo instante conforme a intenção dos grupos sociais e dos agentes de transformação tanto públicos, quanto privados.

As transformações do uso do solo em mercadoria pelos agentes privados ${ }^{3}$ e também pela infra-estrutura proporcionada pelos agentes públicos nessas regiões litorâneas movidas pela demanda turística, passaram a ser atraentes e

\footnotetext{
${ }^{3}$ Construtoras e Incorporadoras.
} 
cada vez mais valorizadas para a exploração imobiliária por meio da segunda residência.

Segundo Ignarra (1999, p. 20), no litoral, também são freqüentes as moradias de antigos pescadores da região serem adquiridas por pessoas de fora da localidade para serem transformadas em segundas residências ou de uso ocasional, mas, ainda, segundo o autor, "o fenômeno mais recente é o da construção de imóveis especificamente para o uso como residência secundária”. $E$ o que vem a ser a segunda residência ou residência secundária? E a primeira residência, o que é? Seabra (1979, p. 4) define os dois tipos de residência da seguinte forma:

“(...) enquanto a produção de uma habitação, digamos a primeira residência, responde à mais elementar necessidade de habitar, morar, de ter abrigo em que se pese as diferentes formas existentes de satisfazer essas necessidades, a segunda habitação foge a qualquer entendimento dessa natureza. Ela é uma segunda habitação (...)".

Entretanto, Seabra (1979, p. 1) diz ainda, "entendemos por segunda residência a habitação cujo uso é eventual, a qual portanto, não se constitui em suporte da vida cotidiana". Estas definições de Seabra (1979, p. 1-4) explicam, de forma simples e clara, estes dois conceitos de primeira e segunda residência, em que a primeira residência está diretamente ligada à função básica de habitar, de morar e de se ter abrigo, enquanto as outras duas definições de segunda residência ou de uso ocasional, estão ligadas a de uma segunda habitação cujo uso é eventual, portanto, não constituindo em suporte de vida cotidiana.

No caso da Estância Balneária de Praia Grande, as segundas residências estão ligadas à história dessa cidade média do litoral sul do Estado de São Paulo há mais de meio século antes da emancipação de São Vicente, ou seja, desde o início do século $X X$, quando as praias, a partir dessa época, constituem-se em grandes áreas de lazer. Neste contexto, Afonso (2006, p. 147) reconhece que as praias para o uso humano, constituíram "a partir do século XX em grandes áreas de lazer". 
Em relação ao entendimento sobre conceito de turismo, sua história, lazer e tempo-livre, fizemos uso dos mais variados autores e entre eles estão: Boyer (2003), Cruz (2003), Dollfus (1991), Gerodetti (2001), Ignarra (1999), Lee (1998), Macedo e Pellegrino (1996), Nicolas (1996), Oliveira (1998), Pires (2002), Rodrigues (1996 e 1999) e outros, os quais discutiram o fenômeno do turismo e nos deram base para o entendimento do turismo, suas origens e implicações e as transformações do espaço ligadas a essa atividade.

O fenômeno do turismo, desde seu surgimento, se constitui como um fenômeno complexo e com as mais variadas definições provenientes dos mais variados autores. De acordo com Ignarra (1999, p. 15), são várias as definições encontradas para o turismo e variam de acordo com a escola de pensamento de seus autores.

Boyer (2003, p. 16), por exemplo, define o turismo como sendo,

“(...) um produto da evolução sociocultural e pode ser definido assim: Turismo = conjunto dos fenômenos resultantes da viagem e da estadia temporária de pessoas fora de seu domicílio, na medida em que este deslocamento satisfaz, uma necessidade cultural da civilização industrial”.

Será que o turismo satisfaz somente uma necessidade cultural da civilização industrial? Será que todo tipo de viagem é considerado turismo, independente da motivação do deslocamento?

Percebemos que, nessa definição de Marc Boyer, o autor não contempla outras formas do turismo que não envolvam uma necessidade cultural, como por exemplo, o turismo de negócios ou de eventos que, no decorrer de nossas pesquisas sobre a cidade de Praia Grande, verificamos que vem despertando interesse por parte da administração pública do mesmo, como uma forma de diversificação de seu portifólio turístico.

Cruz (2003, p. 4) diz que de acordo com a OMT",

\footnotetext{
${ }^{4}$ OMT - Organização Mundial de Turismo
} 
“(...) todo tipo de viagem é considerado, hoje, turismo, independentemente da motivação do deslocamento. Se isso, por um lado, dá origem à chamada segmentação no turismo (turismo de negócios, turismo de eventos, turismo de saúde etc.), por outro lado suscita questionamentos.

Traduzindo em miúdos, o que a OMT sugere com sua definição de turismo é que viagem e turismo são hoje sinônimos".

Como mencionado pela autora, a descrição da OMT diz que todo tipo de viagem é considerado, hoje, como sendo turismo, embora a autora mais adiante destaque em suas citações que "é preciso deixar claro que o conceito de turismo está longe de suscitar alguma unanimidade" (Cruz, 2003, p. 5).

Ainda sobre essa questão envolvendo o deslocamento no turismo, vale ressaltar o que nos disse Ignarra (1999, p. 10) quando ele aponta que "o conceito de turismo, na atualidade, ultrapassa as definições anteriores que se baseavam nas questões de deslocamento para fora das localidades de residência (...)". Ainda, segundo palavras do próprio autor, essas novas definições baseiam-se numa visão sistêmica ${ }^{5}$, haja vista que esta atividade, "possui um interrelacionamento de fatores sociológicos, econômicos, psicológicos e políticoadministrativos" (Ignarra, 1999, p. 10).

Então, quando surgiu esse fenômeno tão difícil de suscitar uma unanimidade de conceitos? Como ele surgiu?

Boyer (2003, p. 19) nos diz que o turismo foi inventado e que as primeiras antecipações datam do século 16, quando alguns viajantes humanistas tiveram curiosidade pela Itália devido ao seu apetite pela antiguidade. Ele ainda nos informa mais adiante:

\footnotetext{
${ }^{5}$ Ao mencionar esta "visão sistêmica", Ignarra (1999, p. 10) se apóia nos ensinamentos do Prof. Dr. Mário Beni, que em sua obra "Análise Estrutural do Turismo", trata desta especificidade do turismo. Ignarra (1999, p.10) segue afirmando que:

"Tal visão sistêmica se mostra fundamental na atualidade, pois até então o turismo se desenvolveu sem uma preocupação maior quanto aos seus impactos nas destinações turísticas. Atualmente, já se observam alguns cientistas procurando aprofundar este conhecimento teórico, visando subsidiar as ações que controlam a atividade turística".

Infelizmente, para nós, essa visão sistêmica depende da vontade dos mais variados agentes para ser transposta para a ação prática.
} 
"Do século 18 ao século 20, a difusão sociocultural encontrou condições cada vez mais favoráveis. Os meios de transporte, a medicina, a pedagogia e a sensibilidade renovaram-se, são todos vetores da grande transformação social, estudados isoladamente em livros científicos, eles ajudaram, acompanharam a penetração do turismo em camadas sociais cada vez mais amplas" (Boyer, 2003 p. 49).

Assim, as grandes transformações sociais ajudaram a penetração e disseminação do turismo na sociedade. O Turismo que, há tempos, era somente um privilégio das classes sociais mais altas, a partir da Revolução Industrial, principalmente a partir dos direitos trabalhistas adquiridos na Europa e que acabaram se alastrando para as demais nações do planeta, passou por mudanças. Hoje, além da burguesia, ele tem uma maior abrangência que se estende a outras camadas da sociedade. Essas mudanças trouxeram tempo livre e lazer. Cruz (2003, p. 38) registra que,

"Tempo livre e lazer não são, portanto, sinônimos. O lazer corresponde a apenas uma parte possível do uso do tempo livre pelo trabalhador. O que cabe ressaltar, porém, é que, cada vez mais, o tempo de lazer ocupa uma porção maior do tempo livre, fora do trabalho".

Também, cabe-se destacar que há uma diferença entre o turismo e o lazer e Oliveira (1998, p. 20-21) nos dá uma clara distinção entre as duas atividades quando afirma:

"Turismo e Lazer, embora atividades diferentes, acabaram unidas pelo capital como forma de negar o ócio (negócio), esse sim uma forma de dispor do tempo livre nas sociedades agrárias. (...) A idéia de lazer pressupõe uma atividade fora do trabalho, em contraposição ao ócio que encaminha o indivíduo para a preguiça, o não trabalho, a desocupação, levando-o ao estado de indolência. (...) Mais do que isso, as atividades de lazer dos trabalhadores logo se transformam em um grande negócio. (...) Lazer e turismo uniram-se após a Segunda Guerra Mundial, através da prática das viagens nos períodos livres dos trabalhadores". 
Contudo, o autor deixou bem claro que embora o turismo e o lazer sejam atividades diferentes, elas acabaram unidas pelo capital, e seus conceitos uniram-se após a Segunda Guerra Mundial, através de viagens nos períodos livres dos trabalhadores.

Sendo assim, para entendermos o fenômeno do turismo temos que levar em conta esses vetores de grande transformação social, o qual menciona Boyer (2003, p. 16). Para dar um maior embasamento acadêmico-científico a este processo evolutivo do turismo, Nicolas (1996, p. 40) destaca:

"O aparecimento do turismo massivo com o destravamento que surge na época das frentes populares na Europa constitui a possibilidade para as classes trabalhadoras de modificarem as suas práticas espaciais, terrivelmente limitadas pela sua falta de recursos e sua falta de tempo livre, gerando a impossibilidade de exercer o turismo reservado às classes dominantes (...). A ruptura da relação espaço/trabalho/vida do trabalhador, é então o prelúdio de formidáveis transformações sociais que chegaram a cobrir a maior parte do mundo". 6

Assim, esses processos de mudanças sociais trouxeram possibilidades do trabalhador e das classes menos privilegiadas de mudarem suas práticas espaciais, antes limitadas pela falta de tempo e de recursos. O Turismo, a partir da revolução industrial e por meio das frentes populares na Europa, como comentadas pelo autor, passou por mudanças. Hoje, está mais acessível, mas Cruz (2003, p. 6) ressalta que "essa quantidade de pessoas que viaja está muito longe de corresponder ao total da população mundial e muito longe, de corresponder à massa da população do planeta". Cabe-se aqui, destacar,

${ }^{6} \mathrm{O}$ texto original diz:

"La aparición del turismo masivo con el destrabamiento que surge en la época de los frentes populares en Europa, constituye la posibilidad para las clases trabajadoras de modificar sus prácticas espaciales, terriblemente limitadas por su falta de recursos y su falta de tiempo libre, generando la imposibilidad de ejercer el turismo reservado a las clases dominantes (...) La ruptura de la relación espacial/trabajo/vida del trabajador, es entonces el preludio de formidables transformaciones sociales que llegaran a cubrir la mayor parte del mundo". 
conforme bem abordado por $\operatorname{Cruz}$ (2003, p. 6), que "turismo de massa não significa 'turismo das massas', pelo simples fato de que as massas não fazem turismo".

Cabe-se ressaltar que o surgimento do turismo massivo ${ }^{7}$ e com o progresso dos meios de comunicação, os quais encurtaram às distâncias-tempo, aliados à melhoria da condição de vida da população paulista, tiveram papel importante para uma maior acessibilidade pelo trabalhador de nosso estado "aos lugares turísticos".

No entanto, Nicolas (1996, p. 43) complementa dizendo, "o elemento tempo é decisivo, não só em relação à duração da viagem, que foi cortada sensivelmente no último meio século graças aos progressos dos meios de transporte (...)". 8 Como nos disse o autor, o elemento tempo é decisivo e os progressos obtidos nos meios de comunicação diminuíram sensivelmente esse tempo de deslocamento de um lugar para o outro.

Desta forma, para se ter acesso ao turismo, não basta somente ter fácil acesso e diminuição do tempo de deslocamento, precisa-se também ter condições econômico-financeiras para arcar com seus custos. No caso de Praia Grande, essa estância tem vários fatores que a beneficiam, além da proximidade com duas, das três regiões mais ricas do país ${ }^{9}$, tem ainda, o fácil acesso e 0 encurtamento das distâncias-tempo proporcionadas pelos progressos dos meios de comunicação que as ligam entre si. Tem ainda, o fato de Praia Grande estar localizada em uma região de turismo litorâneo.

O turismo é uma atividade consumidora de espaço geográfico e, como tal, demanda toda uma infra-estrutura em que as transformações do espaço são

\footnotetext{
${ }^{7}$ Existe uma grande diferença entre turismo massivo e turismo das massas. $O$ turismo massivo é o turismo feito em larga escala, e o turismo das massas é aquele que atrai um grande número de pessoas das classes menos favorecidas da sociedade.

${ }^{8}$ No texto em espanhol diz que, "'el elemento tiempo es decisivo, no solo en relación a la duración del viaje, que se ha acortado sensiblemente en el último medio siglo gracias a los progresos de los medios de transporte (...)".

${ }^{9}$ Segundo o jornal o Diário Regional de 14 de dezembro de 2006 (capa), o IBGE aponta que a região do $A B C$ está em terceiro lugar entre as maiores riquezas do país e está apenas atrás da metrópole de São Paulo, seguida do Rio de Janeiro.
} 
inevitáveis e o processo de urbanização destas áreas litorâneas vêm recheados de acréscimos técnicos que valorizam ainda mais o uso do solo.

Assim, segundo Nicolas (1996, p. 44), o espaço, neste contexto, não é somente o elemento que permite trocar de lógica, trocar de mundo, mas,

“(...) é também um fator construtivo da experiência do turismo. Existem vários argumentos a favor desta afirmação. Por uma parte o turismo é consumidor de espaços, tanto que o turismo geralmente desfruta da simples visão do espaço, quanto os elementos construtivos de uma paisagem que pode ser reconhecida como turística". ${ }^{10}$

Devido ao fato do espaço, ser também, um fator construtivo da experiência do turismo, é de interesse da Estância Balneária de Praia Grande continuar investindo na melhoria da infra-estrutura local, nessa mudança de paisagem onde, conforme afirma o autor, o turismo é uma atividade consumidora do espaço, em que se exigem facilidades de acesso, melhorias nos serviços básicos de segurança, saneamento, saúde pública e outros. Assim, no que tange ao provimento de infra-estrutura básica e viária necessária para o desenvolvimento de lugares turísticos é importante que haja uma aliança entre os setores públicos e privados criando-se diferenciais, vantagens em relação a outras localidades turísticas.

Em relação à Praia Grande, essa cidade-média, tem uma vantagem em relação a outras opções do turismo: o mar, o sol e seus $22,5 \mathrm{~km}$ de praias.

No entanto, para compreendermos o conceito de cidade-média, recorremos a Deus (2002) que, no capítulo IV de sua tese, "O sudeste goiano: as transformações territoriais da desconcentração industrial brasileira”, nos fornece

${ }^{10} \mathrm{O}$ texto original diz:

“(...) es también un factor constructivo de la experiencia del turismo. Existen varios argumentos a favor de esta afirmación: Por una parte, el turismo es consumidor de espacios, en tanto que el turismo generalmente disfruta tanto la simple visión del espacio, como los elementos constructivos de un paisaje que puede ser reconocido como turístico". 
subsídios para o entendimento desse conceito. Em sua tese, o autor faz uma interpretação geográfica que tem por finalidade principal, a observação de como a descentralização econômica e industrial brasileira possibilitou a concentração populacional em poucos e esparsos núcleos espalhados pelo território goiano, onde algumas cidades, mesmo não atingindo os índices quantitativos, exercem a função de cidade média. O autor aborda alguns conceitos de cidade média aceitos no Brasil e no mundo. Segundo Deus (2002, p. 223), pelos critérios da ONU ${ }^{11}$, as cidades-médias são "aglomerações urbanas com população de 100 mil a um milhão de habitantes". Ele continua dizendo que, em relação ao Brasil, segundo os critérios formulados pelo IBGE ${ }^{12}$, são consideradas cidades médias, "as unidades urbanas com população entre 100 e 500 mil habitantes".

Deus (2002, p. 224) fundado em Soares, ao discutir os critérios das instituições oficiais, ONU e IBGE, argumenta que existe "uma certa concordância em classificá-la segundo os critérios populacionais, tendo em vista as facilidades e a pouca complicação com o tema, não sendo considerados outros aspectos importantes para sua compreensão". Segundo o autor, apesar das vantagens e facilidades das análises quantitativas, existem outras formas de se analisar o conceito de cidade média, dada as "inúmeras distorções em um país de dimensões continentais como o Brasil" (Deus, 2002, p. 224).

Dessa forma, para entendermos o processo de evolução urbana de Praia Grande, buscamos Suzuki (1996) que, ao falar da transição do rural ao urbano em Rondonópolis, em sua dissertação, discute as repercussões da produção do espaço neste município. O autor também contribuiu para um maior conhecimento da parte metodológica utilizada em seu trabalho de pesquisa e que serviu como base na elaboração do nosso trabalho.

À medida que começamos a fazer nossos levantamentos sobre a ocupação desta cidade média paulista, conhecida como Estância Balneária de Praia Grande, percebemos a importância da participação dos acréscimos técnicos, como pontes e viadutos, para a ocupação mais efetiva de Praia Grande.

\footnotetext{
${ }^{11}$ ONU - Organização das Nações Unidas

${ }^{12}$ IBGE - Instituto Brasileiro de Geografia e Estatística
} 
Santos (1996, p. 51) nos diz algo interessante sobre os objetos técnicos:

\begin{abstract}
"Através da presença desses objetos técnicos: hidroelétricas, fábricas, fazendas modernas, portos, estradas de rodagem, estradas de ferro, cidades, o espaço é marcado por esses acréscimos, que lhe dão um conteúdo extremamente técnico".
\end{abstract}

Assim, devido ao fato de o espaço ser marcado por estes acréscimos técnicos, no caso de Praia Grande, estes acréscimos, que passaram a ocorrer do início do século passado para cá, tiveram papel importante no processo de urbanização desta cidade-média.

Com a construção da Fortaleza $^{13}$ e logo depois com a inauguração da Ponte Pênsil em 1914, o acesso à região de Praia Grande foi facilitado, embora, na época, ainda era muito precário. Em relação à Fortaleza, Toschi $(2003$, p. 12) diz:

${ }^{13}$ Localizada na Praia Grande, a Fortaleza de Itaipu ocupa uma área de 2 milhões e 400 mil $\mathrm{m}^{2}$ e faz parte do Parque Xixová Japuí. Sua construção foi iniciada em 1902 e surgiu devido à necessidade de se construir um forte mais moderno para defender a entrada do canal que dá acesso ao Porto de Santos. O complexo do Itaipu foi construído nos terrenos de quatro sítios: o Sítio de Itaipu, o Sítio Prainha, o Sítio Itaquitanduba e o Sítio Suá, os quais pertenceram respectivamente ao Capitão Mor José Gonçalves de Aguiar, a Antonio José da Silva Bastos, Maria Benedita Viana e o último também de propriedade do Capitão Mor José Gonçalves de Aguiar. Foram todos adquiridos pelo governo federal para a construção da Fortaleza.

Secomandi (2005, p. 63) nos informa que a Fortaleza do Itaipu, com obras iniciadas em 1902, foi idealizada para substituir a Fortaleza de Santo Amaro, a qual data de 1584. Todo o complexo que forma a Fortaleza do Itaipu, o qual é composto pelos Fortes Duque de Caxias, Rego Barros e Jurubatuba, ocupa pontos estratégicos elevados em um esporão rochoso coberto pela Mata Atlântica e que se necessário, bloqueia a via de acesso marítimo ao estuário, que abriga o maior Porto da América do Sul, o Porto de Santos.

O almanaque mensal do jornal O Diário de Santos, de dezembro de 1902, traz o seguinte a respeito de sua construção:

"De acordo com os planos do Governo Federal para fortificar o nosso porto, mandando construir vários fortes em pontos estratégicos, existe aqui uma Comissão Militar que prossegue nos trabalhos, para os quais também o Governo do Estado concorre neste exercício com 200 contos de réis. A comissão iniciou seus trabalhos pela construção do Forte de Itaipu (na ponta de igual nome a Sudeste da barra)". 
"(...) Foi a fortaleza que praticamente começou a dar vivência à Praia

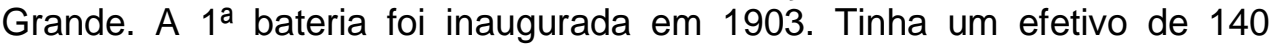
homens sob o comando do capitão Tude Bastos Neiva Lima. No começo do século, o sítio Itaipu, com 100 braças, pertenceu ao capitão-mor Aguiar. A área se chamava sítio Prainha, registrada em 06 de janeiro de 1856".

Segundo a opinião da autora, foi praticamente a Fortaleza (ver foto 01) que deu vivência à Praia Grande. Este complexo militar que começou a ser construído em 1902 foi a primeira construção de importância na Estância Balneária de Praia Grande.

Entretanto, cabe-se ressaltar que Praia Grande sempre esteve ligada ao nosso passado, à nossa infância e hoje em dia à nossa vida adulta. O interesse pelas questões relacionadas à segunda residência e turismo tornou-se mais concreto com o nosso ingresso no curso de Pós-graduação em Geografia Humana da USP. São muitas as memórias e transformações pelas quais passou essa cidade desde a nossa tenra infância. Lembramo-nos de quando criança (próximo dos 5 e 6 anos de idade, na primeira metade da década de 1970) das dunas que existiam em suas praias, e que hoje, já não existem mais; ou ainda, quando dezenas de ônibus lotavam as areias duras das praias, com os famosos turistas de um dia (ver foto 02 ) ou "farofeiros". ${ }^{14}$

\footnotetext{
${ }^{14}$ Esta expressão é utilizada para designar os turistas ocasionais, em geral, turistas de um dia, com poucos recursos e que levam refeições para a praia.
} 
Foto 01 - Ponta de Jurubatuba, destinada à 1aㅡ Bateria, inaugurada em 1903

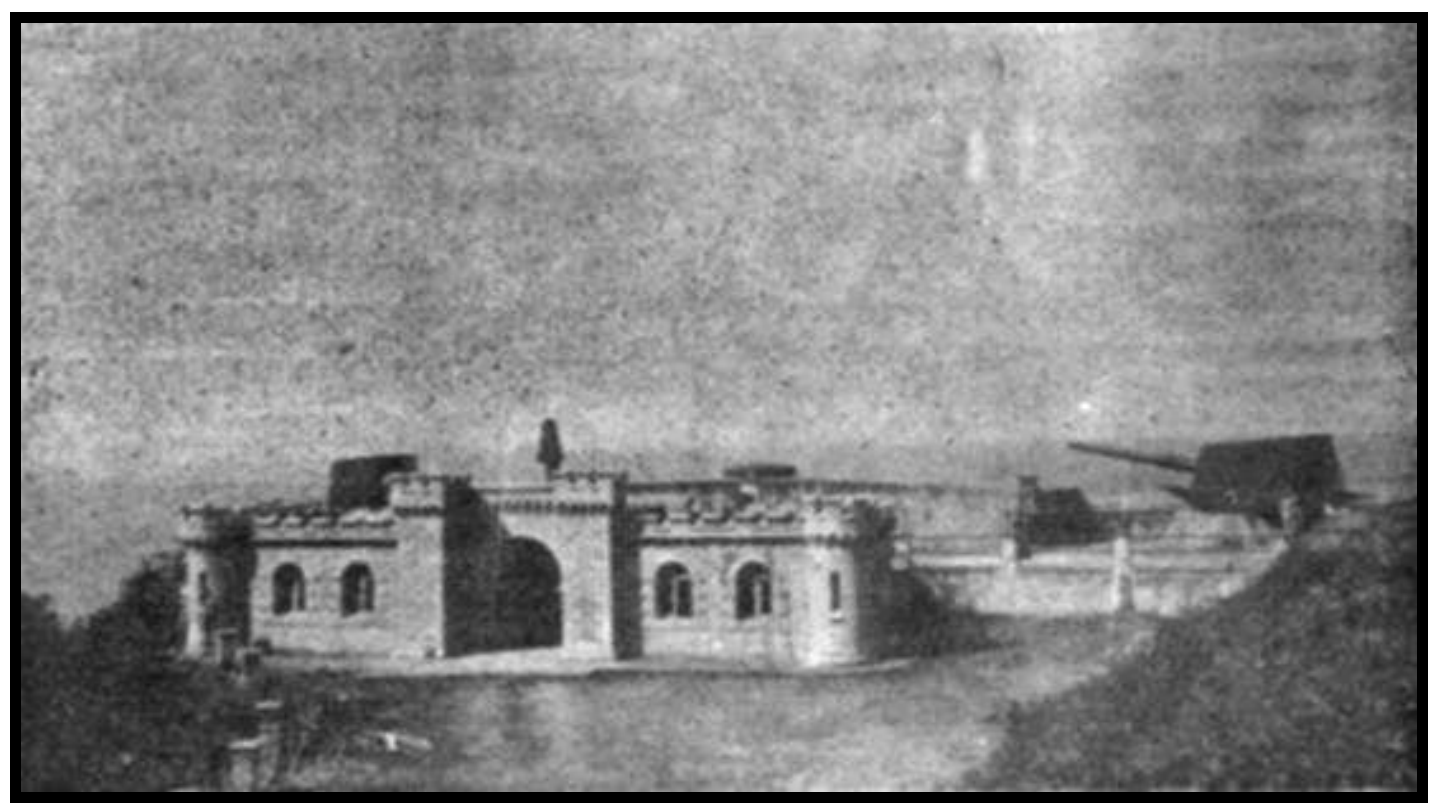

Fonte: Disponível em http://www.novomilenio.inf.br/pg/pgh004g.htm, acesso em 25/12/2006, por Imário Vieira. Autor desconhecido

Nesta foto, vemos o que mais parece um castelo medieval com um canhão Schneider Canet ao lado.

O processo de verticalização de Praia Grande, na década de 70, começava a intensificar-se, mas ainda era muito comum em vários bairros encontrarmos áreas totalmente desprovidas de prédios (ver foto 02) nas regiões próximas à orla marítima. 
Foto 02

Vista aérea de Solemar na década de 1970

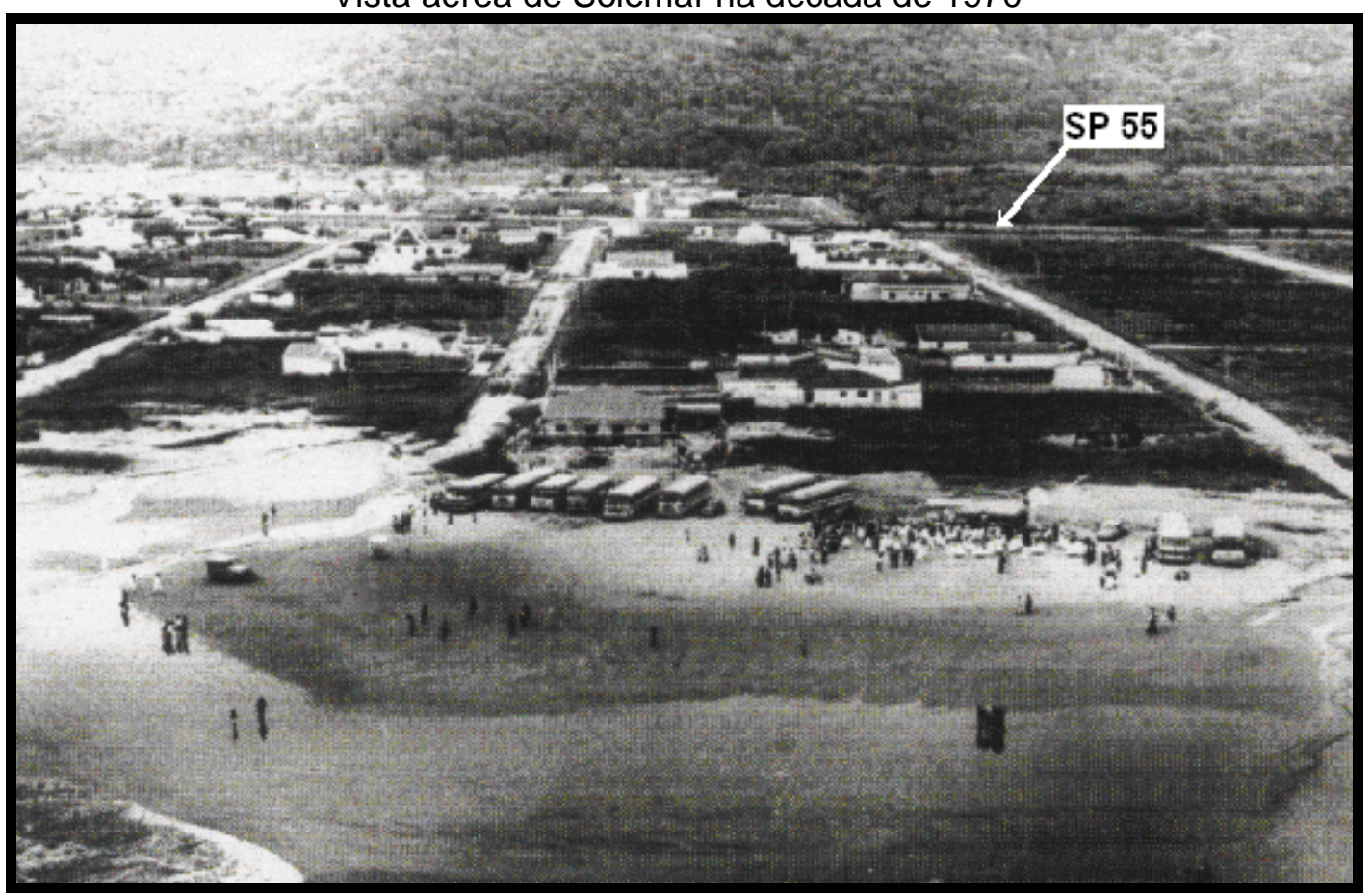

Fonte: SIQUEIRA, Fátima Valéria; SILVA, Mônica Solange Rodrigues;CALIS, Magna Flora. Paisagens da memória: história de Praia Grande. Praia Grande, SP: Prefeitura da Estância Balneária de Praia Grande, 2002, p.102. Adaptação: Imário Vieira. Autor desconhecido.

Bairro de Solemar no princípio da década de 1970, com poucas moradias e desprovido da incipiente verticalização da região central desta cidade-média paulista. Este bairro está localizado no extremo oeste de Praia Grande e faz divisa intermunicipal com Mongaguá. No canto superior esquerdo da foto, temos poucas casas tanto do lado direito quanto do lado esquerdo da SP 55. Já no canto superior direito, há lotes sem habitação alguma e com pouca degradação da Mata Atlântica, ao norte, acima da SP 55. Por fim, no canto inferior, os vários ônibus e alguns carros estacionados na orla da praia com seus respectivos turistas de "um dia". As ruas transversais sem pavimentação e sem a Avenida Beiramar. O acesso a região, nesta época, dava-se pela SP 55 ou Rodovia Padre Manuel da Nóbrega (antiga Pedro Taques) e também pelas areias da Praia.

No entanto, foram muitas as transformações urbanísticas que aconteceram, nessa estância balneária, desde o princípio do século passado até os dias atuais, não só na orla da praia, mas por todos os lados dessa estância, novos loteamentos, casas substituídas por prédios de alto padrão, plantação de coqueiros por toda a orla, construção de ciclovia, praças etc. 
Nesse sentido, realizamos uma análise das transformações ocorridas no espaço e como ocorreu o processo de urbanização da Estância Balneária de Praia Grande. Para tal, recorremos num primeiro instante, à história, para entendermos como foi construída a relação de São Vicente, e conseqüentemente Praia Grande, com a metrópole de São Paulo. Buscamos compreender qual era o papel de Praia Grande neste contexto histórico com a metrópole e como se deu o processo de urbanização de São Vicente, por ter sido o município ao qual Praia Grande pertenceu até 19 de janeiro de 1967.

No entanto, o problema de pesquisa está relacionado à proximidade geográfica da Estância Balneária de Praia Grande, com importantes pólos emissores, como, por exemplo, a região metropolitana de São Paulo, que ao mesmo tempo que dinamiza o crescimento das segundas residências da cidade, também afeta a sua qualidade como estância balneária e a vida de seus moradores.

O objetivo geral desta pesquisa é o de analisar o processo histórico da urbanização de Praia Grande, desde a época em que ainda fazia parte de São Vicente e entender como se deu a produção do espaço amparada pelo turismo de segunda residência.

Os objetivos específicos são:

- compreender suas relações com a metrópole desde os primórdios de sua história, como ocorreu a ocupação da região onde hoje está localizado essa estância balneária e conhecer quais foram os primeiros loteamentos feitos na em Praia Grande;

- entender como ocorreu essa invenção ou até mesmo essa "re-invenção da Estância Balneária de Praia Grande", buscando o que foi feito em termos de melhorias e infra-estruturas ao longo desses últimos anos e o que causou essa invenção ou "descoberta" ou até mesmo, essa "re-descoberta dessa cidademédia" pelos turistas;

- verificar quais as conseqüências que o surgimento e crescimento do número de segundas residências, em razão da proximidade com grandes áreas metropolitanas, tem causado a essa estância e a população local; 
- conhecer o que a população local e os turistas pensam sobre a infraestrutura da cidade, o que o turismo de segunda residência trouxe de bom e de ruim para essa estância.

As hipóteses desse objeto de estudo sobre a ocupação e urbanização na região da Estância Balneária de Praia Grande foram divididas em quatro áreas:

- ocupação: a ocupação na região da Estância Balneária de Praia Grande teve como marco a construção da Fortaleza do Itaipu a partir de 1902;

- urbanização: o processo de urbanização foi influenciado pela sua relação com a metrópole de São Paulo e aquisições de segundas residências na cidade;

- segunda residência: a exploração imobiliária causada pelo turismo de segunda residência trouxe mais benefícios ou malefícios à cidade;

- qualidade como estância: sua qualidade como estância é afetada pelo grande fluxo de turistas de segunda residência que freqüentam suas praias.

Dentro desse contexto, a justificativa para a realização dessa pesquisa deuse pela importância que Praia Grande tem nos destinos turísticos das populações das regiões metropolitanas, já que, segundo o Guia do Profissional de Eventos para Santos e Região (2003, p. 130), a Estância Balneária de Praia Grande "está entre os primeiros destinos do turismo doméstico brasileiro, segundo a Embratur. (...) e dados da Ecovias, de cada cem veículos que passam por hora no Pedágio [da Imigrantes], 43 têm Praia Grande como destino". Segundo informações coletadas nesse guia pela equipe organizadora, percebemos a importância da Praia Grande como destino turístico nos dias atuais, principalmente após a entrega da pista descendente da Rodovia dos Imigrantes em 2002. Portanto, tornou-se importante a execução de um estudo analítico no que tange à sua infraestrutura turística, bem como uma análise para sabermos se a mesma era capaz de um atendimento adequado como uma Estância Balneária, sem comprometer sua qualidade como tal, devido ao grande fluxo de turistas das regiões metropolitanas que tem como destino suas praias.

Ainda, cabe-se ressaltar que não havia muitas referências bibliográficas e científicas sobre a Estância Balneária de Praia Grande e daí o interesse em 
pesquisar o tema. Assim, ao percebermos a carência de informações científicas, aumentou o nosso interesse pela área de estudo.

Sendo assim, ressaltamos que uma outra razão que nos motivou a realizarmos essa pesquisa foi a transformação do espaço, ocorrida desde a sua emancipação e, mais ainda, a partir do início da década de 90, quando percebemos que essas mudanças têm alterado decisivamente a paisagem do lugar, a qual, segundo Dollfus (1991, p. 46), "é a parte visível do espaço". Nesse sentido, foram devido a estas mudanças visíveis na paisagem, tais como a existência de mais de 1200 câmeras de segurança implantadas, plantação de milhares de coqueiros em sua orla, modernização e padronização dos quiosques, construção de ciclovias, novas praças, melhorias de infra-estrutura e tantas outras, que nos despertaram o interesse pela produção do espaço e o turismo de segunda residência em Praia Grande. Dentro desse contexto, basta irmos a essa estância balneária para percebermos empiricamente as transformações e 0 grande fluxo de turistas que para lá se desloca aos finais de semana, férias e feriados, seja de turista de segunda residência ou não.

Santos (1992, p. 49), entre suas várias definições de espaço, conceitua-o como "um produto em constante transformação". Foram essas "transformações" do espaço, que instigou-nos a buscar mais a fundo a história dessa cidade-média e a importância do turismo de segunda residência nessas transformações.

Portanto, nossa metodologia de pesquisa procurou entender os fatos com base em documentação relacionada à Estância Balneária de Praia Grande. Para isso, recorremos às mais variadas fontes históricas tais como: mapas, jornais, registros em cartórios da região, relatos de antigos moradores etc. Utilizamos iconografias, as quais de acordo com Volvelle (1987, p. 45), "podem parecer mais 'inocentes' ou, afinal de contas mais reveladoras que o discurso escrito ou oral, graças às significações que delas podemos extrair". Assim, a pesquisa utilizou como suporte ao referencial bibliográfico: as iconografias, as fotos de arquivos públicos e de antigos moradores da região, bem como legislações e documentos oficiais envolvendo a estância desde o início de sua ocupação para moradia e o lazer litorâneo. 
Percebemos, em nossos levantamentos, que a necessidade do uso de áreas litorâneas para o lazer tem sido objeto de pesquisa muito difundido entre os pesquisadores da Geografia. Oliveira (1998, p. 11) afirma:

"A importância que tem assumido o uso de áreas litorâneas para o lazer balneário, em praticamente todo o litoral brasileiro, têm levado muitos pesquisadores a se debruçarem sobre este fenômeno, destacando seus vários aspectos: econômico, cultural, ambiental, etc. Resultado e condição do uso balneário de áreas litorâneas, a urbanização acelerada apresenta como principal característica a existência de 'ondas' de especulação imobiliária".

Analisando o que o autor nos retrata, notamos a existência dessas tais "ondas" de especulação imobiliária nessa estância balneária, diante de tantos prédios e condomínios em construção nos dias atuais.

Apoiamo-nos também nas contribuições de Goulart (1996, p. 7), que afirma, "não basta saber que o país se urbanizou. (...) o importante é saber como se urbanizou e construir modelos teóricos para descrever e explicar esse processo, para poder atuar sobre ele".

As reflexões de Goulart (1996, p. 7) nos induzem a buscar como a cidade de Praia Grande se urbanizou, como se transformou e construir modelos teóricos para descrever esse processo de urbanização, que se deu desde o princípio do Século XX para cá, especificamente a partir de 1902, com a construção da Fortaleza de Itaipu.

\section{Estrutura dos capítulos}

$\mathrm{Na}$ introdução, faremos uma breve abordagem teórica sobre o turismo e suas origens no Brasil e no mundo, articulando conceitos de turismo, tempo livre e lazer com a produção do espaço urbano e turístico, bem como o surgimento do banho de mar e o início das atividades turísticas em Praia Grande.

No primeiro capítulo, realizaremos um resgate da história da Estância Balneária de Praia Grande e como se deu a sua ligação com o Planalto Paulista desde os primórdios da colonização, em especial, com a atual Região Metropolitana 
da Grande São Paulo (RMSP). Nesse capítulo, faremos uma abordagem histórica de como foi o início da ocupação do seu território e sua ocupação mais recente. Também, falaremos do seu sítio urbano e de sua localização no contexto da Região Metropolitana da Baixada Santista (RMBS).

No segundo capítulo, abordaremos o surgimento do turismo litorâneo, o banho de mar e o início da atividade turística em Praia Grande. Discutiremos a exploração imobiliária e o papel da segunda residência no crescimento urbano dessa estância balneária. Também, abordaremos como era o tecido urbano no final da segunda metade do século passado, sua nova forma urbana e o seu processo de verticalização.

No terceiro e último capítulo, falaremos das especificidades do processo de urbanização de Praia Grande, tais como: sua emancipação da cidade de São Vicente, o aumento de sua população, questionaremos o paradeiro da sua população mais carente, como é o seu novo tecido urbano, como se deu o recente processo de reurbanização da orla e adjacências, seus impactos ambientais, sua qualidade como estância balneária, seu novo tecido urbano e o seu novo Plano Diretor. E, para finalizar, destacaremos os principais atrativos turísticos da Estância Balneária de Praia Grande e sua atual infra-estrutura hoteleira. 


\section{CAPÍTULO I - RESGATE DA HISTÓRIA DA ESTÂNCIA BALNEÁRIA DE PRAIA GRANDE}

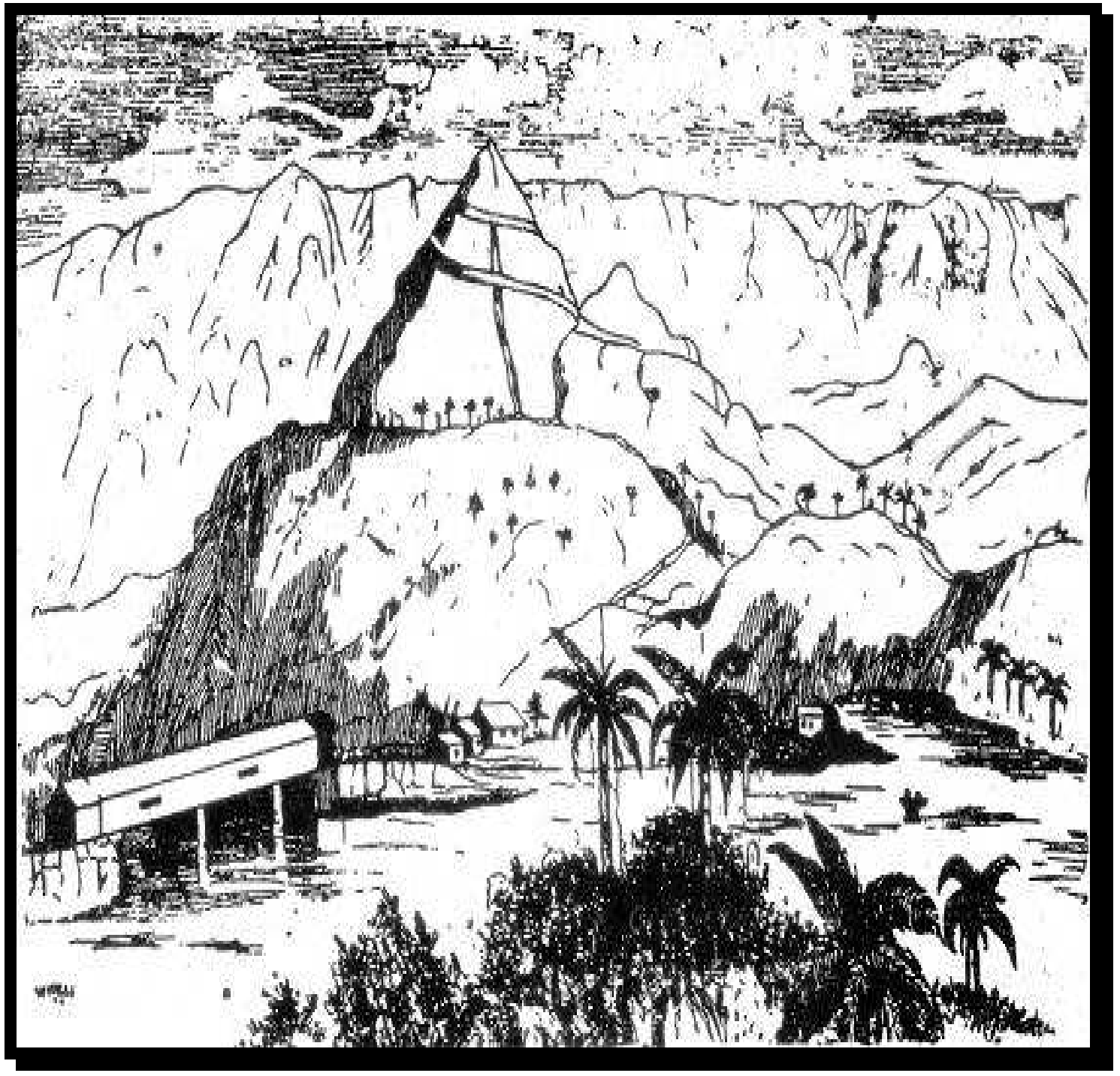


Para termos um maior entendimento das transformações que ocorreram ao longo dos anos no espaço de Praia Grande, precisamos recuar no tempo. Sendo assim, optamos por fazer um breve resgate histórico, buscando a origem da sua ligação com a metrópole de São Paulo e do seu nome, o início da ocupação quando a região ainda era habitada por índios tupis e quando ainda fazia parte da cidade de São Vicente. Buscaremos com isso, um ponto inicial de reconhecimento da região, antes de abordarmos a ocupação mais recente da história dessa estância balneária.

\section{1 - Ligação do litoral com o planalto paulista}

Diferente dos dias atuais, em que a ligação da Região Metropolitana da Baixada Santista com a metrópole de São Paulo e adjacências é feita por meio de estradas modernas e ágeis, logo no início da colonização, transpor essa grande muralha que dificultava a comunicação e a circulação entre a região do litoral e a região do planalto paulista, representou para os habitantes da época, um grande desafio. Em 1560, Mem de Sá encarregou aos jesuítas esta tarefa de abrir um novo caminho além das estreitas picadas indígenas. Desse modo, Barreiros (2002, p. 5-7) atesta que,

"A história da ligação entre a Baixada Santista e o planalto paulista tem início em 1560, quando Mem de Sá encarregou os jesuítas a abrir um novo caminho pela Serra do Mar que, até então, era realizado através de estreitas picadas indígenas que não eram adequadas às tropas de burros que transportavam víveres e demais mercadorias". (Barreiro,2002, p.7)

Continua o autor,

"Desde o início da colonização do Brasil, o sistema de circulação e transporte da Baixada Santista é vital para a economia nacional. Foi graças à ligação do planalto paulista com o mar que se estabeleceu a possibilidade de se alargar as fronteiras (...)". (Barreiros, 2002, p. 5)

Nesse sentido, era de vital importância esse sistema de circulação, ligando o planalto ao mar, por meio da criação de caminhos para o tráfego de pessoas e 
de mercadorias de uma região a outra. Em 1560, Mem de Sá ao perceber o caráter estratégico para o alargamento das fronteiras e colonização do Brasil, encarregou aos jesuítas esta função de abrir um novo caminho garantindo a comunicação com estas regiões da Capitania de São Paulo. Desse modo, os jesuítas tiveram grande importância no alargamento das fronteiras e na circulação entre o planalto paulista com as regiões litorâneas a partir do século XVI.

Sendo assim, em 1600, a comunicação entre São Paulo de Piratininga com Itanhaém era feita por um desses caminhos e passava por Praia Grande (ver figura 01). Ao chegar a São Vicente, fazia-se a travessia por barcos ou canoas até a área do Sítio "Prainha" (ver foto 03), onde hoje está localizado parte do complexo da Fortaleza do Itaipu, e dali por diante, seguia-se por trilhas até encontrar as areias duras de Praia Grande, as quais eram utilizadas como caminho para se chegar a outras regiões do litoral sul do atual estado de São Paulo.

Figura 01 - São Paulo de Piratininga em 1600

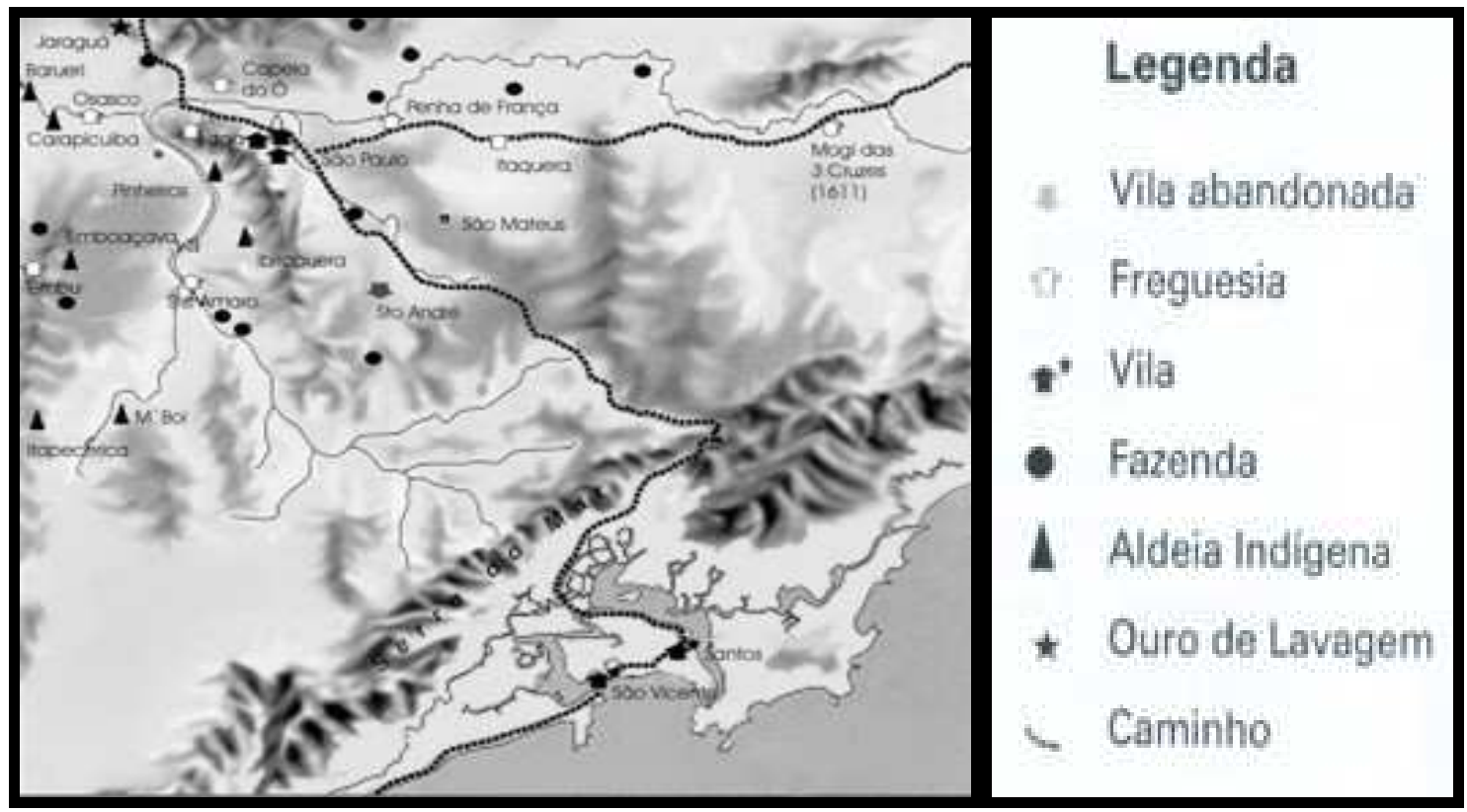

Fonte: Isto é Brasil 500 anos: Atlas histórico. São Paulo: Editora Três, 1988, p.23.

Embora essa figura não tenha boa qualidade, ela mostra o trajeto feito entre a São Paulo de Piratininga de 1600 e algumas regiões do litoral paulista. A figura serve para firmar um aspecto importante, ou seja, o caráter estratégico que a região de Praia Grande tinha como caminho e via de acesso para se chegar às regiões de Itanhaém e adjacências. 
Foto 03 - Vista aérea do antigo Sítio Prainha

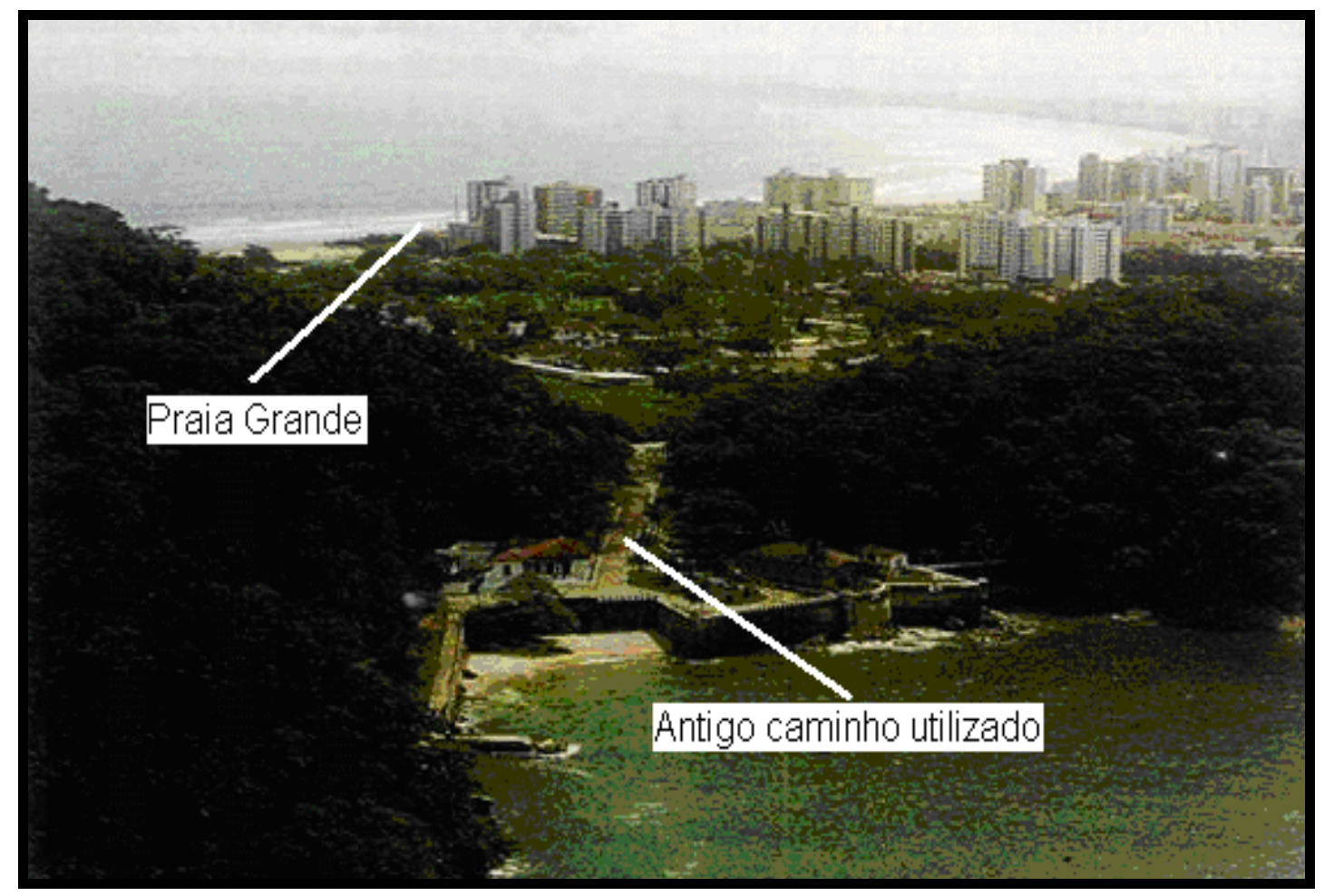

Disponível em: http://www.novomilenio.inf.br/pg/pgh004c.htm, acesso em 06/11/2006, por Imário Vieira - Autor desconhecido

O Sítio Prainha está localizado no canto inferior da foto (ao centro), onde vemos parte da Fortaleza do Itaipu, construída no início do século passado e cercada pela mata do atual Parque Estadual Xixová/Japuí. Esta região, conforme o mapa (ver figura 03) era utilizada nos idos do Século XVI e até princípio do Século XX (antes da aquisição e construção da Fortaleza do Itaipu) e possibilitava um curto acesso às praias que hoje em dia pertencem à Estância Balneária de Praia Grande. Atualmente, não é permitido o acesso à Estância Balneária de Praia Grande por meio do "Sítio Prainha", pois o mesmo pertence ao complexo militar da Fortaleza do Itaipu. No entanto, existiam outros caminhos que eram utilizados e que passavam por Praia Grande, tais como: o do Rio Piaçabuçu, chamado de "Caminho do Porto do Piaçabuçu", o qual saía do Porto do Piaçabuçu e fazia a ligação com a praia, um pouco adiante do supõe-se que seja, nos dias atuais, os bairros da Aviação e Tupi. Deste caminho do Piaçabuçu, saíam duas trilhas: a primeira era a Trilha do Guaramar e a segunda trilha era a Trilha do Coquepucu. Um outro caminho utilizado era conhecido como 'os caminhos do Rei', o qual ligava o Porto do Campo ou antigo Porto do Rei à Praia do Boqueirão. 
Desse modo, a representação de São Paulo de Piratininga em 1600 (ver figura 03) mostra que a relação de Praia Grande com a atual metrópole de São Paulo data do início da colonização do Brasil, pois, nessa época (século XVI), Praia Grande, era passagem obrigatória para quem ia de Itanhaém e adjacências para São Paulo de Piratininga e vice-versa, o que não impedia que caiçaras se fixassem na região.

No entanto, ao falar desses caminhos de ligação com o planalto paulista, Barreiros (2002) enuncia que:

"Com o tempo, e devido às peculiaridades climáticas da Serra, as condições do caminho dos jesuítas foi se deteriorando e, em 1661, o Governo da Capitania de São Vicente mandou construir a Estrada do Mar, com mais de 70 pontes. Essa nova ligação permitia o tráfego de Veículos movidos à tração animal. Em uma terceira etapa, em 1789, Bernardo José de Lorena, governador da Capitania, determinou a Recuperação do Caminho do Mar e a pavimentação com lajes de granito no trecho da Serra, a chamada Calçada de Lorena, que ainda está, em parte, preservada". (Barreiros, 2002, p. 7)

Assim,

"Em 1837, teve início à construção da Estrada da Maioridade (em homenagem à maioridade de Dom Pedro II). O traçado da nova estrada utilizou parte do antigo traçado da Estrada do Mar. A nova estrada foi, em parte, financiada com cobrança da 'Renda de Barreira', lei do Império que autorizava a cobrança de uma espécie de pedágio.(...) Em 1922, o Caminho do Mar recebeu experimentalmente, pavimentação de concreto em seus trechos mais íngrimes.(...) Em 1928, parte da estrada recebeu pavimentação asfáltica. Já se discutia a necessidade da construção de uma nova estrada com maior capacidade e desenho mais adequado ao automóvel. Isso só ocorreu em 1939, quando tiveram início as obras da Via Anchieta". (Barreiros, 2002, p. 7)

Desse modo, o primeiro caminho feito pelos jesuítas, seguido pelo Caminho ou Estrada do Mar, pela da Calçada de Lorena e pela Estrada da Maioridade, e outras que se seguiram, foi de extrema importância para a comunicação entre a região do planalto paulista com as regiões da Baixada Santista. Esse elo de 
ligação entre essas regiões, com o passar do tempo, foi mostrando seu caráter estratégico e de vital importância para o desenvolvimento da colônia.

Sendo assim, essa ligação utilizando esses caminhos e estradas da Serra do Mar, a qual era feita por meio de carroças ou no lombo de animais de tração, quando chegava em São Vicente tinham que utilizar outros meios de transporte, como as canoas, pois não dava para chegar a Itanhaém por caminhos normais, em alguns trechos, somente por caminhos ou estradas fluviais. No entanto, Siqueira (2002, p. 58) nos relata que existiam caminhos utilizados para se chegar a Praia Grande, mas eram por meio de rios: o Piacabuçu, o Guaramar, o das Cruzes e o Idaiatuba. É provável que o mais utilizado tenha sido o caminho do Rio Piacabuçu, por muito tempo utilizado pelos caiçaras/pescadores como uma estrada fluvial para o povoamento da região até chegar à região das Caieiras. Nessa região, havia um pequeno porto de trapiche, chamado de Porto do Piaçabuçu, e como diz a autora, "desse ponto em diante, as pessoas seguiam caminho até a areia dura da praia e depois em direção à Itanhaém" (Siqueira, 2002, p. 58).

Acredita-se que esses caminhos que durante séculos foram utilizados para chegarem a Intanhaém, e que passavam pela capitania de São Vicente, facilitaram o início da ocupação dessa região do litoral paulista.

\section{2 - Início da ocupação}

Muito tempo antes da construção da Fortaleza do Itaipu, se deu a colonização irregular do Japuí e da área situada às margens do Mar Pequeno, a qual pertencia a São Vicente e onde hoje está localizada a cidade de Praia Grande.

A origem de seu nome vem do tupi "peaçabuçu"15. Há muito tempo, nos primórdios do descobrimento, a Praia era conhecida como Peaçabuçu pelos índios tupis da região, tempos depois, passou a denominar-se Praia Grande, em função dela ser realmente grande e de uma extensão invejável e, também, em

\footnotetext{
${ }^{15}$ Peabuçu, Piacabuçu ou Piacabusu é uma palavra de origem Tupi, a qual significa Porto Grande.
} 
decorrência de existir em seu nome indígena, o sufixo uçu, usu ou uasu (que na língua tupi quer dizer "grande"). ${ }^{16}$

O processo de colonização do Brasil e da região de São Vicente, do qual Praia Grande pertenceu até o princípio da segunda metade do século passado, tem suas raízes no sistema de capitanias hereditárias, segundo Thomas (1981, p. 39):

"D. João III transportou ao Brasil o sistema de doações (...). O Brasil foi divido em longas faixas de terras, que mediam de 40 a 100 léguas na costa, e que, no interior, se encontravam delimitadas pela linha de Tordesilhas. Originalmente surgiram quinze capitanias, que foram entregues a doze donatários. Estes exerciam, nos seus domínios, um poder geral, civil e judiciário, e se encontravam na posse de numerosos privilégios. Mas simultaneamente, assumiam obrigações de colonizar e desenvolver as suas capitanias".

Uma dessas capitanias, das quais menciona o autor, foi a de São Vicente que séculos mais tarde, com desmembramentos, daria origem à cidade de Praia Grande. Thomas (1981, p. 39-40) complementa dizendo que "as possibilidades do cultivo de cana-de-açúcar, que alcançou grande importância com o estabelecimento dos donatários no Brasil, constituíram sem dúvida, um motivo de atração para ocupação da colônia".

Sendo assim, o donatário de São Vicente, Martim Afonso de Souza, e os das demais capitanias, ao perceberem a possibilidade do cultivo da cana-deaçúcar no território brasileiro, vislumbraram os grandes ganhos que teriam com a exploração desta colônia constituindo-se, de acordo com Thomas (1981, p. 3940), um motivo para a sua ocupação. O único problema encontrado seria a escassez da mão-de-obra, que foi resolvida, num primeiro momento, por meio da escravidão de povos indígenas e que mais tarde seria substituída pelos povos de origem africana.

\footnotetext{
${ }^{16}$ Navarro, Eduardo de Almeida. Dicionário de Tupi Antigo - A língua indígena clássica do Brasil. São Paulo: Editora Global (no prelo).
} 
No entanto, com relação à mão-de-obra escrava indígena e africana utilizada para o cultivo da cana-de-açúcar e outras culturas na Capitania de São Vicente, Siqueira (2002) comenta:

"Os habitantes de São Vicente, Santos e São Paulo criavam guerras só para aprisionar índios e escravizá-los. Preferiam sempre os tupis e guaranis, que consideravam de mais fácil convívio, apesar deles serem os principais aliados dos portugueses desde o início da colonização" (Siqueira, 2002, p. 41).

Em relação à escravidão de negros africanos, a autora continua:

"Quem fazia o trabalho da roça e os serviços de casa eram os escravos negros, de origem africana. Eram tantos na época, que constituíam mais da metade da população da região. Hoje em dia, nada sobrou dos sítios e dos pequenos engenhos. Permanecem apenas os nomes de alguns deles nos nomes de bairros atuais" (Siqueira, 2002, p. 45).

Assim, vemos que a escravidão tanto indígena como africana se fez presente nos costumes dos antigos habitantes e senhores de engenho da região de São Vicente, onde a mão-de-obra escrava era utilizada na roça e nas atividades domésticas diárias.

Em relação a essa população indígena, Siqueira (2002, p. 30) nos relata que há 500 anos, ainda permaneciam na região, que compreendia a capitania de São Vicente, povos indígenas, principalmente povos de língua tupi, como os Tupinambás, os Tupiniquins e os Carijós, os quais, infelizmente, não existem mais, em decorrência das guerras, escravidão e também pelas doenças trazidas pelos seus colonizadores. Siqueira (2002) fundada em Hans Staden ${ }^{17}$ nos informa que:

\footnotetext{
${ }^{17}$ Segundo Siqueira (2002) nos informa, Hans Staden foi um artilheiro que escapou de um naufrágio em 1551, no litoral sul do Brasil e que ao retornar a Europa, relatou, em seu livro, suas aventuras em nosso país.
} 
“(...) os índios Tupi do litoral preferiam morar em lugares onde encontravam água, lenha para o fogo, caça e pesca, Quando esgotava o alimento do local, mudavam-se para outro. Construíam grandes cabanas arredondadas, cobertas com palha de palmeira, sem divisória interna, onde moravam várias famílias. Cada uma ficava com um canto da cabana, onde acendia o seu fogo. Em uma aldeia havia cerca de sete cabanas" (Siqueira, 2002, p. 34).

No entanto, vemos aqui retratados o nomadismo e a precariedade das habitações desses antigos moradores da região de Praia Grande e adjacências com suas habitações cobertas por palhas onde moravam várias famílias.

Desse modo, nesses primórdios da ocupação, o deslocamento dessa população era feito de forma precária, os meios de transporte mais utilizados, entre as regiões de Praia Grande e as Vilas de São Vicente e Santos, eram as canoas, as quais transportavam seus moradores até um pequeno Porto, chamado de Piacabuçu e que desse ponto em diante, seguiam por terra por meio de caminhos e trilhas.

São Vicente foi a primeira vila oficialmente fundada no Brasil. Em relação a isso, Azevedo (1992, p. 28) aponta:

\begin{abstract}
"A mais antiga, a primeira vila oficialmente instalada no Brasil - bem sabido - foi a de São Vicente, no ano de 1532, no litoral paulista. Coube a Martim Affonso de Souza demarcar-lhe o terreno, arruá-lo, loteá-lo, distribuindo os lotes aos sesmeiros; fez levantar um forte, a casa da Câmara, a cadeia, a igreja, a alfândega; e, dando-lhe uma organização político-administrativa, nomeou os administrativos da justiça e convocou os 'homens bons' para procederem à eleição dos primeiros vereadores".
\end{abstract}

Desse modo, já no século XVI, houve com a demarcação de terrenos, arruamentos e até mesmo loteamentos distribuídos aos sesmeiros pelo seu capitão donatário Martim Afonso de Souza ${ }^{18}$. Também houve, em São Vicente, um

\footnotetext{
${ }^{18}$ Siqueira (2002, p. 10) comenta que o rei de Portugal, após dividir o Brasil em capitanias hereditárias, entregou a Martim Afonso de Souza a capitania de São Vicente. Ele esteve aqui no Brasil entre 1532 e 1533 fundando vilas e explorando a terra, depois disso voltou a Portugal, envolveu-se com as companhias das Índias e nunca mais retornou ao Brasil.
} 
princípio de urbanização que se efetivou com a construção de um forte, com cadeia, igreja, alfândega, dentre outras edificações para administrar tal vila.

Vale ressaltar que as vilas e cidades criadas no Brasil no século XVI, tinham um traço em comum, ou seja, localizavam-se à beira-mar por motivos de segurança, comodidade e barreiras naturais. Assim, como nos diz Holanda (1994, p. 141-146), uma das características das primeiras cidades brasileiras foi a sua localização no litoral, em uma faixa de até $100 \mathrm{~km}$ da costa, ao contrário das cidades e vilas fundadas, como, por exemplo, pelos espanhóis, as quais eram posicionadas geralmente no interior, como uma ratificação de sua intenção de alí se estabelecerem e fincarem suas raízes, demonstrando sua intenção de se construir algo sólido nas terras colonizadas. Além das razões já mencionadas e tantas outras, era mais fácil para os moradores dessas vilas e cidades, localizadas em regiões próximas à orla, manterem contato com as naus procedentes da metrópole e também por estarem mais próximos do mar para quando quisessem voltar a Portugal. Essa ligação da colônia com a metrópole era muito importante e de caráter estratégico para Portugal.

Portanto, esses fatos históricos, novamente, nos remetem ao que disse Holanda (1936, p. 70) sobre o Brasil-colônia. Ele nos lembra que, para os portugueses da época, a colônia era apenas um lugar de passagem. E continua dizendo que, "eles vinham apenas em busca de fortunas impossíveis, sem imaginar criar fortes raízes na terra".

Sobre esses primórdios da colonização de nosso país, Castro (1996, p. 147), ao falar dessa época, complementa dizendo: "não encontrando no Brasil, de imediato, as riquezas minerais que tanto almejavam, os portugueses deram ao território recém-conquistado uma atenção apenas secundária, garantindo sua presença aí, pelo estabelecimento de feitorias (....)". Sendo assim, a autora nos esclarece que a importância dada ao Brasil, nessa época era de caráter apenas secundário e vista como feitorias. Dentro deste contexto, as vilas desempenhavam papel importante entre a corte portuguesa e o Brasil. 
Entretanto, a vila de São Vicente foi, por muito tempo, para as metrópoles portuguesas, o canal de entrada para os primeiros portugueses que para o Brasil se dirigiram com o fim de colonizar e explorar as riquezas de nosso país. Ressaltamos que estavam entre seus primeiros investidores aqueles dispostos a construírem engenhos para produção do açúcar com sua posterior exportação às metrópoles portuguesas e européias.

Sendo assim, após sua elevação a vila, em 22 de janeiro de 1532, a município, em 29 de outubro de 1700 e a Comarca em 23 de setembro de 1961, São Vicente mudou muito. Desde a época de sua elevação a vila, houve muitos desmembramentos que deram origem a novos povoados, freguesias, vilas ${ }^{19}$, e hoje em dia, cidades; entre elas, a de Praia Grande (Machado Junior, 2005, p. 13). Cabe-se lembrar que, aqui, São Vicente inicia-se como uma exceção, ou seja, não foi freguesia como os demais povoados de sua época, pois passou diretamente de povoado a vila.

De acordo com mapas da Cartografia Paulista antiga, ainda nessa época, a Vila de São Vicente tinha uma extensão muito maior do que se pensava. Essa Capitania ia desde a ponta de Guaratuba do Norte, caminho da Vila de São Sebastião, até à Praia de Peruíbe e Caminho de Iguape para o sul. Cabe-se destacar que, a Estância de Praia Grande era conhecida como Praia de Conceição [do Intanhaém], outro nome antigo dado à região de Praia Grande. Nessa época ainda se encontravam na região, muitos indígenas da nação Tupi.

$\mathrm{Na}$ citação que segue, Thomas (1982, p. 14) ao falar dos Tupis das zonas costeiras diz o seguinte:

\footnotetext{
${ }^{19}$ De acordo com o IGC (Manual de Municípios e Distritos do Estado de São Paulo, p.11) traz as seguintes definições para povoado, freguesia e vila:

Povoado - categoria inerente aos aglomerados que se encontram submetidos territorial e administrativamente a outros núcleos, não dispondo, assim, de autonomia e jurisdição própria.

Freguesia (atual distrito) - denominação da sede e da área correspondente a uma circunscrição que contém um núcleo urbano (anterior povoado), porém dependente da administração municipal.

Vila (atual município) - categoria em que o núcleo urbano e respectivo território, originalmente denominado termo, passa a ter autonomia territorial e administrativa, caracterizada pela existência de poder público representado por Prefeitura e Câmara de Vereadores.
} 


\begin{abstract}
"Os Tupi das zonas costeiras viviam no nível econômico das culturas simplesmente plantadoras. Conheciam uma forma primitiva da agricultura, que era realizada mediante as queimadas, das roças. Entre as plantas típicas cultivadas figura a mandioca, que ainda hoje é de grande importância na alimentação da população brasileira, assim como o milho, o feijão e algumas plantas industriais. Também eram coletados frutos das plantas tropicais. Ao lado disso, a caça e a pesca, nos rios e no mar, tinham uma certa importância (...) Não possuíam animais de tração ou carga. Como moradia, utilizavam as casas conhecidas sob o nome de malocas. A maloca abrigava uma linhagem. Uma ou mais linhagens formavam uma aldeia que, em geral, representava a forma organizativa superior dos índios da floresta tropical".
\end{abstract}

Portanto, com o que nos relata o autor, dá para termos uma noção do perfil dos antigos habitantes da região onde hoje se encontra a Estância Balneária de Praia Grande. Seus antigos moradores viviam ao nível econômico das culturas simplesmente plantadoras muito similar a que é praticada hoje pelos sitiantes e fazendeiros de nosso país por meio das queimadas das roças. O autor também nos fala da pesca nos rios e no mar, o qual ainda em nossos dias é um recurso natural abundante em Praia Grande. Essa estância possui nove rios e uma orla marítima, nos dias atuais, de $22,5 \mathrm{~km}$. O autor também fez menção à forma de habitação desses antigos moradores, "as malocas". Ele comenta ainda que uma ou mais linhagens formavam uma aldeia.

Segundo Siqueira (2002, p. 45), na região que é hoje conhecida como Praia Grande, pelos recenseamentos de 1765, também os do início de 1800, já existiam ali, moradores. Essa comunidade caiçara, embora pequena, vivia da pesca e de pequenas culturas, tinha ainda, algumas cabeças de gado, plantava arroz, mandioca, milho, batata doce, pimenta, tomate, cana de açúcar, abacaxi, laranja e café. Esses caiçaras que ali se fixaram nos idos dos séculos XVIII e XIX, podem tê-lo feito, em razão da utilização dos caminhos que ligavam Itanhaém a São Paulo. É provável que, encantados com as belezas de Praia Grande, resolveram fixarem-se na região, marcando assim, uma das primeiras ocupações, da hoje Estância Balneária de Praia Grande.

No entanto, ao observarmos o relato de Siqueira (2002, p. 45), percebemos que houve mudanças de costume nos antigos habitantes da região de Praia 
Grande na época desses dois recenseamentos, de 1765 e 1800, em relação ao que nos tinha comentado Thomas (1982, p. 14) nos primórdios da colonização. Essas mudanças foram a introdução de animais de tração ou carga e a introdução e cultivo de outras culturas, além da mandioca, utilizada pelos indígenas.

Dentro desse contexto, Siqueira (2002, p. 45) continua a descrição desses primeiros habitantes de Praia Grande antes do século XX e diz que eles também faziam chapéus de palha, aguardente e farinha, e vendiam parte de sua produção nas vilas de São Vicente e Santos para comprarem outros gêneros e produtos dos quais necessitavam.

Assim, de acordo com o dados extraídos da Enciclopédia dos Municípios Brasileiros (IBGE. Enciclopédia dos Municípios Brasileiros. Rio de Janeiro: IBGE, 1958. v. XXX, p. 274.), publicada pelo IBGE, em 1958, é de crença generalizada admitir-se que a ocupação dessa parte do litoral brasileiro, onde se encontra hoje a Praia Grande, a qual pertencia na época, a Capitania de São Vicente, se tenha dado a partir da chegada de Martim Afonso, em 1532. Thomas (1981, p. 39) diz que "o sucesso da expedição de Martim Afonso de Souza impulsionou a Coroa portuguesa a uma ocupação definitiva da colônia americana".

De acordo com a matéria do jornal A Tribuna (A TRIBUNA, Santos, 19 jan. 1989. Caderno Baixada \& Litoral, s.p.), diz-se que a história de Praia Grande remonta a 1510 ,

“(...) quando em razão da colonização irregular de São Vicente, vieram para cá os colonizadores, formando os primeiros povoados. Por mais de três séculos, formou-se na área denominada Peaçabuçú (que quer dizer Praia Grande), um núcleo caiçara que povoava desde as encostas do Morro Xixová ate a zona de Itinga (divisa com Mongaguá). Com a agregação entre os caiçaras e os sitiantes do Rio Branco, começou o desenvolvimento da economia vicentina."

Esse grupo de caiçaras que a matéria enuncia vivia do cultivo de pequenas culturas e também tirava seu sustento da pescaria. É provável que essa antiga população de caiçaras e sitiantes de Praia Grande, com a Lei de Terras de 1850, tenha perdido o direito do uso dessa terra, por se tratarem, em sua grande maioria, 
de índios, negros e pescadores analfabetos. Mônica Solange Rodrigues ${ }^{20}$, em um artigo do jornal "A Tribuna" (PRAIA Grande. A Tribuna, Santos, 19 jan. 2008. Especial. 2 p.), nos informa que "após tomarem as terras dos caiçaras e dos negros, intermediários acabaram vendendo esses bens para loteadores, dando início ao processo de criação dos loteamentos (...)".

Sendo assim, a atividade econômica vicentina foi por muito tempo ligada a atividades primárias e também, em tempos mais recentes, a indústria. No jornal $\mathrm{O}$ Monumento (SENRA, Jorge Bierrenbach. O Monumento, São Vicente, Ano III no 23, jul. 1983.), dá-se um relato de como era a atividade econômica da região de São Vicente em 1883:

\begin{abstract}
"Em 1883, afora de alguma pequena lavoura de cana, que se encontrava em um ou outro sítio, da plantação de bananeiras, de horticulturas de abacaxi, ananaes e melancia, da indústria extrativa de madeiras e lenha, e do fabril de cal de casca de marisco, e alguma pescaria, não possuía este município outras lavouras e indústrias.

A decadência da lavoura e indústria neste que foi berço da Província, e fora outrora tão florescente pela abundância de cultura de cana, arroz, mandioca, e mesmo trigo e vinho e indústria que tanto nela medraíam, como atesta sua velha história e confirmam as ruínas de importantes estabelecimentos abandonados.

Eram nos tempos e vão longe, os habitantes deste e do município vizinho ${ }^{21}$, opulentos Senhores de Engenhos e considerados cidadãos entregues aos labores da agricultura e indústria quando na pujança de seus teres e haveres e da benéfica influência de que cercavam, ajudavam e protegiam à pequena lavoura ao redor de seus importantes e ricos domínios: compreendiam assim que da prosperidade geral seus bens também tornavam-se de melhor valor".
\end{abstract}

No entanto, nesta matéria, percebemos que pouco antes do início do século passado ainda persistiam, em São Vicente, pequenas lavouras que eram encontradas em um ou outro sítio que se dedicava ao cultivo de cana, bananas, abacaxis, melancia e também faziam a extração de lenha, o que era bem diferente dos tempos de outrora quando São Vicente e Santos ainda eram lugares de ricos

${ }^{20}$ É historiadora e uma das escritoras do livro "Paisagens e memória: história de Praia Grande" e também responsável pela Seção de Patrimônio Histórico desta estância balneária.

${ }^{21}$ Aqui, o autor deste artigo, o jornalista Jorge Bierrenbach Senra, do jornal $O$ Monumento, refere-se à cidade de Santos. 
Senhores de Engenho e detentores de poder, que se dedicavam à agricultura e à indústria.

O arquiteto Eliseu de Andrade Júnior, referindo-se ao princípio do século passado, um dos conhecedores da história praiagrandense, de acordo com jornal A Tribuna (A TRIBUNA, Santos, 24 abr. 1983. Especial Cidades. Capa.) , diz o seguinte sobre Praia Grande:

"(...) as terras interiores, como se chamavam os terrenos junto aos morros, eram utilizadas para a agricultura, principalmente no cultivo da banana.

Foi a fase áurea da banana, cujo maior consumidor era a Argentina".

Sendo assim, até as primeiras décadas do século $X X$, o distrito de Praia Grande, sobrevivia de uma agricultura de subsistência e da exploração dos seus recursos naturais, traços básicos da economia brasileira da época. Sua economia local dependia principalmente da exploração da lenha, que era vendida aos moradores vicentinos e santistas. Também vendiam sua lenha para a Estrada de Ferro Sorocabana e para o Porto de Santos.

Vale ressaltar que, assim como foi mencionado pelo arquiteto Eliseu de Andrade Júnior, o cultivo da banana esteve entre algumas das culturas utilizadas por seus antigos moradores para produção de capital na região de Praia Grande. A fase áurea da banana e da exploração de seus recursos naturais passou e a partir do início do século $X X$, a economia e o modo de vida da região foi sofrendo mudanças que marcariam profundamente os rumos da história da região praiagrandense e da baixada santista.

Portanto, a dinâmica da economia e acumulação de capital vincentina, até então, era baseada na produção de alguns gêneros agrícolas, no comércio e no incipiente processo de industrialização de alguns setores, mas, a partir do início do século XX, São Vicente passou a ter um amplo crescimento do setor terciário serviços, setor financeiro, comércio aliado à indústria da construção civil como condição de seu desenvolvimento. Esse processo de transformação requeria a 
produção de outros espaços, e Praia Grande, permitiria essa expansão de São Vicente em direção a outras regiões da cidade.

Desse modo, a ocupação e produção desses outros espaços que se realizou em Praia Grande, sob a égide do capitalismo, da propriedade privada do solo e por meio da fragmentação do espaço que foi vendido em pedaços em Praia Grande, faz com que o espaço entre no circuito das trocas e dando ao mesmo um caráter de mercadoria. Dessa forma, essa migração de um setor da economia para o outro, marca uma ocupação mais recente na região de Praia Grande.

\section{3 - Ocupação mais recente}

Marcando esse processo de ocupação mais recente, uma das primeiras mudanças ocorridas em Praia Grande, no princípio do século XX, se deu com a intervenção do Estado, que desapropriou uma extensa área para a construção de uma Fortaleza, e com isso, vieram as primeiras investidas em infra-estrutura para a região. Nessa época, já existiam alguns sítios que pertenciam a prováveis remanescentes dos primeiros moradores da região de Praia Grande, entre eles destacamos os sítios: Momboatuba, Carvalho, J. Gonçalo, Pae Felipe, J. de Azevedo Cunha, Taperinha, Boguaçu, Guaramá, Itaipu, Prainha, Itaquitanduba, Suá e alguns outros.

Nesse contexto, o início da construção da Fortaleza do Itaipu ${ }^{22}$, que ocorreu em 1902, mudou os destinos de quatro destes sítios, pois sua construção levou à aquisição e à mudança de propriedade dos mesmos. Por volta do início do século passado, foram adquiridos pelo governo federal, o Sítio Itaipu de propriedade do Capitão Mor Aguiar, o Sítio Prainha, de propriedade de Antonio José da Silva Bastos, o Sítio Itaquitanduba, de propriedade de Maria Benedita Viana e o Sítio Suá, cuja propriedade também era do Capitão Mor Aguiar.

Nessa época, entre final do século XIX e início do século XX, e ainda com uma carência de infra-estrutura básica, o Distrito de Praia Grande, já contava com uma escola (ver foto 04) que funcionava na casa de uma de suas antigas moradoras, Dona Maria Pacheco Nobre, que atendia pelo apelido carinhoso de

\footnotetext{
${ }^{22}$ A construção da Fortaleza do Itaipu foi dada a partir de uma determinação do Presidente Campos Sales.
} 
Dona Mariquinha Nobre. Em relação a isso, Siqueira (2002, p. 84-85) documenta que Dona Mariquinha lecionava em sua própria casa e as aulas eram dadas para um grupo misto de alunos. Dona Circe Sanchez Toschi também relata que, em 1926, as aulas eram ministradas na casa do capataz do loteamento do Jardim Guilhermina, Sr. Claudino, lugar onde hoje esta localizada a Colônia de Férias da Associação dos Comerciários da Cidade de Praia Grande.

Portanto, a construção da Fortaleza do Itaipu iniciada, em 1902, marcou o princípio de uma ocupação mais recente em Praia Grande, tempos depois, viriam as estradas de rodagem, de ferro, o primeiro hotel e restaurante, os primeiros loteamentos, as primeiras casas de comércio, o telégrafo, a energia elétrica, as pontes ligando sua região à região da sede da cidade de São Vicente, na llha de Santo Amaro, entre outras melhorias.

Foto 04 - Maria Pacheco Nobre com seus alunos no início do Séc XX Acervo particular de Jaime Caldas

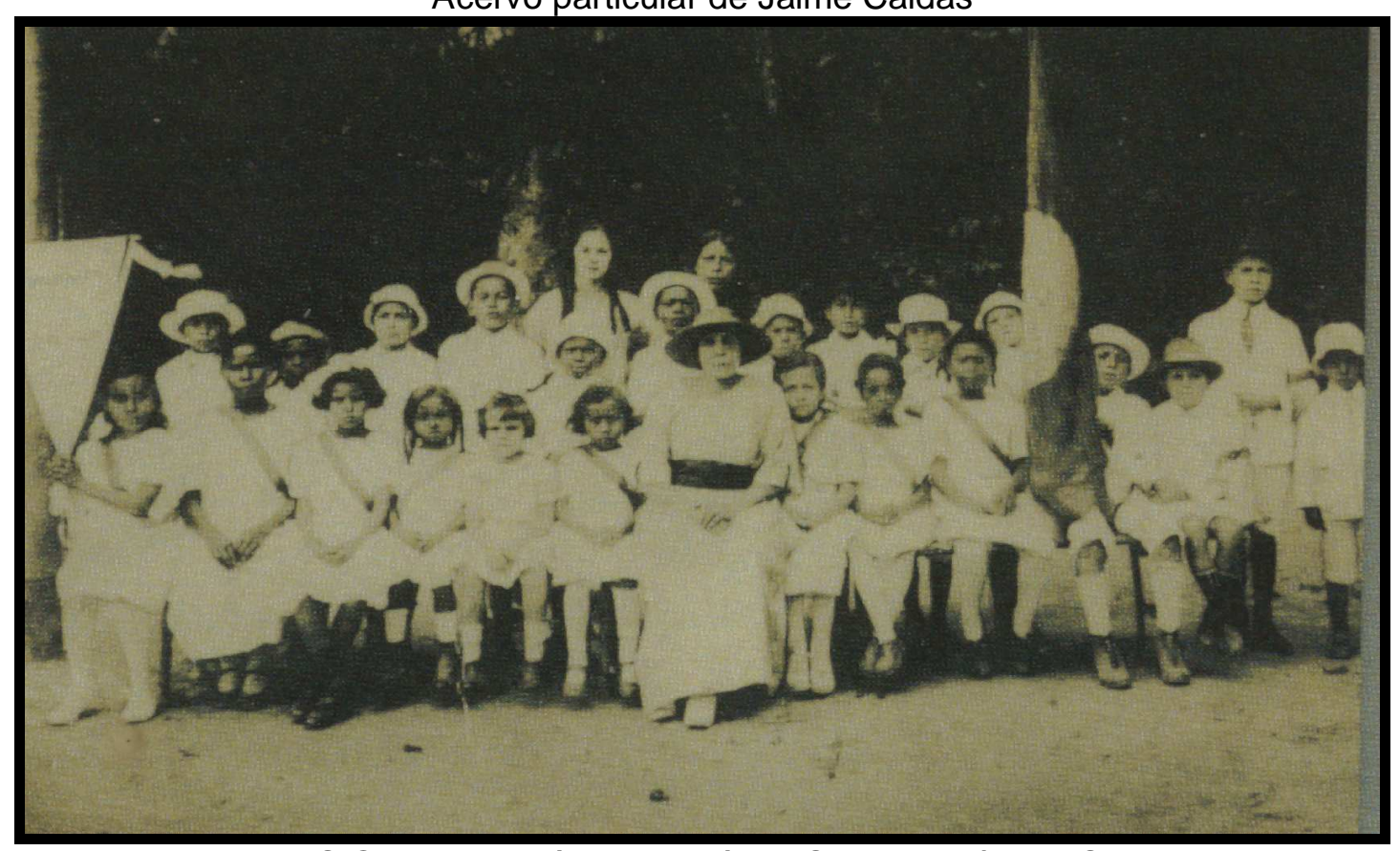

Fonte: SIQUEIRA, Fátima Valéria; SILVA, Mônica Solange Rodrigues;CALIS, Magna Flora. Paisagens da memória: história de Praia Grande. Praia Grande, SP: Prefeitura da Estância Balneária de Praia Grande, 2002, p. 84. Autor desconhecido.

Vemos na foto, Dona Mariquinha Nobre, ao centro, cercada por seus alunos, entre eles, descendentes de prováveis ex-escravos da região. 
Dessa forma, desde o início da construção da Fortaleza do Itaipu, em 1902, e com a entrega da Ponte Pênsil, em 1914 (ver foto 05), junto com a construção de uma estrada (ver foto 06) fazendo a ligação entre São Vicente e a Fortaleza do Itaipu, a intervenção do Estado foi de grande importância para o crescimento e ocupação mais recente desta parte da cidade de São Vicente. Assim, com essas intervenções dos agentes públicos, o acesso à região de Praia Grande foi muito facilitado, e, em conseqüência desses acréscimos técnicos, a circulação das pessoas que iam e vinham de Praia Grande aumentou, impulsionando o seu crescimento e urbanização.

Portanto, no princípio do século XX, a infra-estrutura básica do distrito de Praia Grande, era um prolongamento daquela que possuía a cidade de São Vicente, que na época apoiava-se no setor terciário que dependia das atividades comerciais que mantinha com a cidade de Santos devido às atividades portuárias. Cabe-se ressaltar que a metrópole de São Paulo, por sua vez, desde os primórdios dos tempos, polarizou a economia da região litorânea, devido à sua proximidade com o Porto de Santos, o qual era utilizado como porto de entrada e saída de produtos e mercadorias que iam e vinham do exterior.

No ano de 1909, a população caiçara de Praia Grande resolveu construir sua primeira capela (ver foto 07) para congregar a pequena população de sitiantes da região e do ainda distrito do município de São Vicente.

Sendo assim, a construção desse patrimônio religioso também marcou a história do povoamento praiagrandense. Nesse sentido, Marx (1991, p. 13-14) diz algo em seu livro "Cidade no Brasil terra de quem", que se aplica ao caso Praia Grande, quando nos diz que:

“(...) A constituição do patrimônio duma nova capela exigia algumas condições, implicava certas conseqüências. Aquelas estão na raiz da germinação urbana, estas no tronco do seu florescimento. O patrimônio religioso decidiu o nascimento dum sem-número de povoações no litoral e nos vastos sertões". 
Foto 05 - Ponte Pênsil em 1914

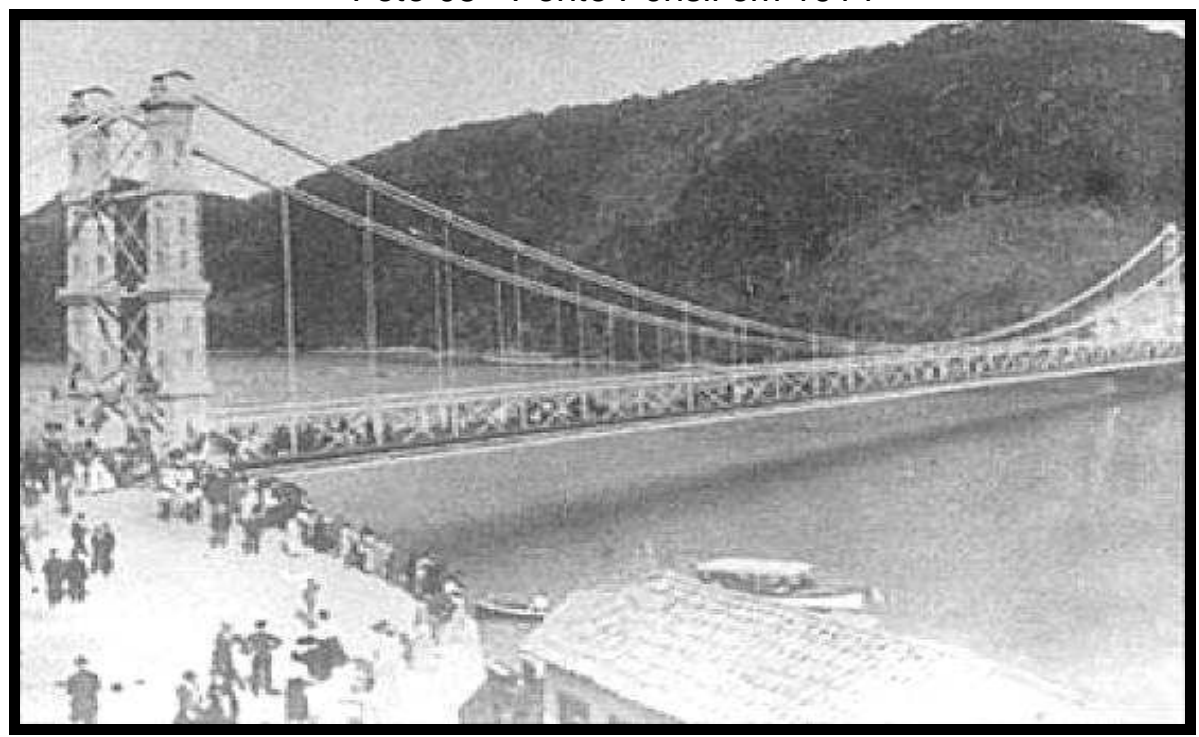

Fonte: Disponível em http://www.novomilenio.inf.br/sv/svf021.htm, acesso em 09/01/2007, por Imário Vieira - Autor desconhecido

Foto da inauguração da Ponte Pênsil, em 1914, onde vemos ao fundo, parte da Mata Atlântica, ainda intocada e sem construção alguma. Eram grandes as filas que se formavam de pessoas e automóveis para visitarem a majestosa ponte e marcarem sua presença neste evento histórico para a região da cidade de São Vicente e adjacências.

Foto 06 - Estradinha que liga a Ponte Pênsil a Praia Grande em maio de 1928

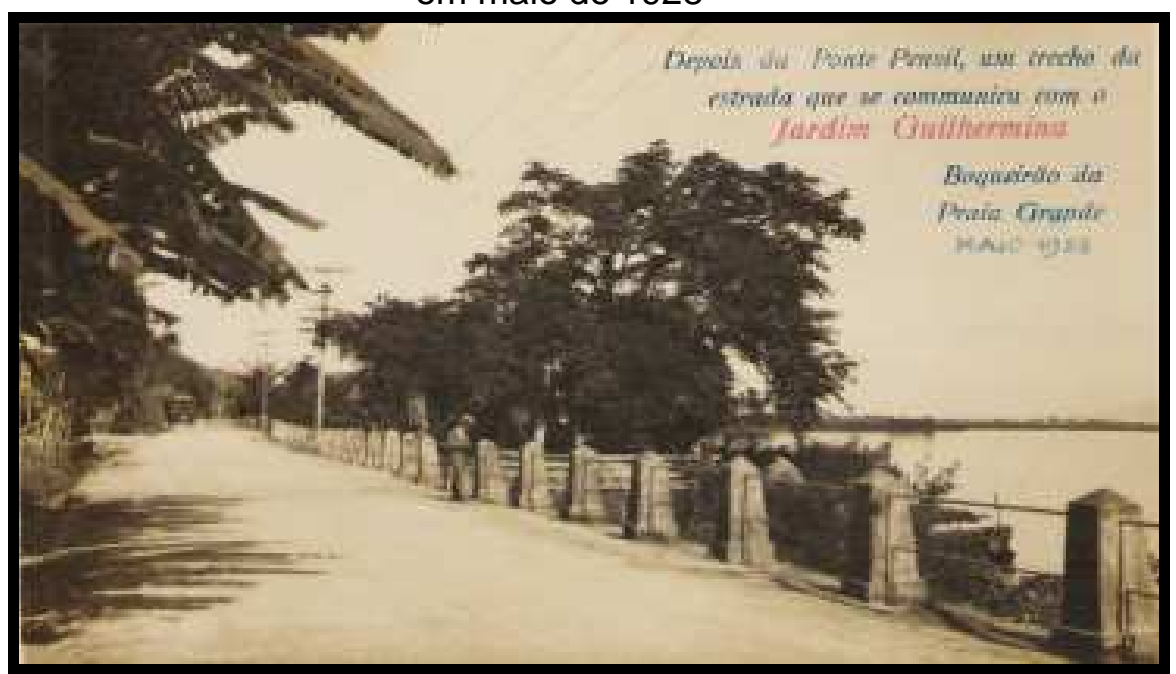

Fonte: Acervo particular de Circe Sanchez Toschi - Autor desconhecido

Logo após a passagem pela Ponte Pênsil, temos esta pequena estradinha construída no princípio do século passado e que ainda está em uso nos dias atuais. Por muito tempo foi a única estrada de ligação entre a região da sede da cidade vicentina na Ilha de Santo Amaro e o Distrito de Praia Grande. Ela foi construída na mesma época da construção da Ponte Pênsil e também era utilizada para o transporte de suprimentos e armamentos para a Fortaleza do Itaipu. 
Foto 07 - Ruínas da primitiva Capela de Santo Antônio do Boqueirão

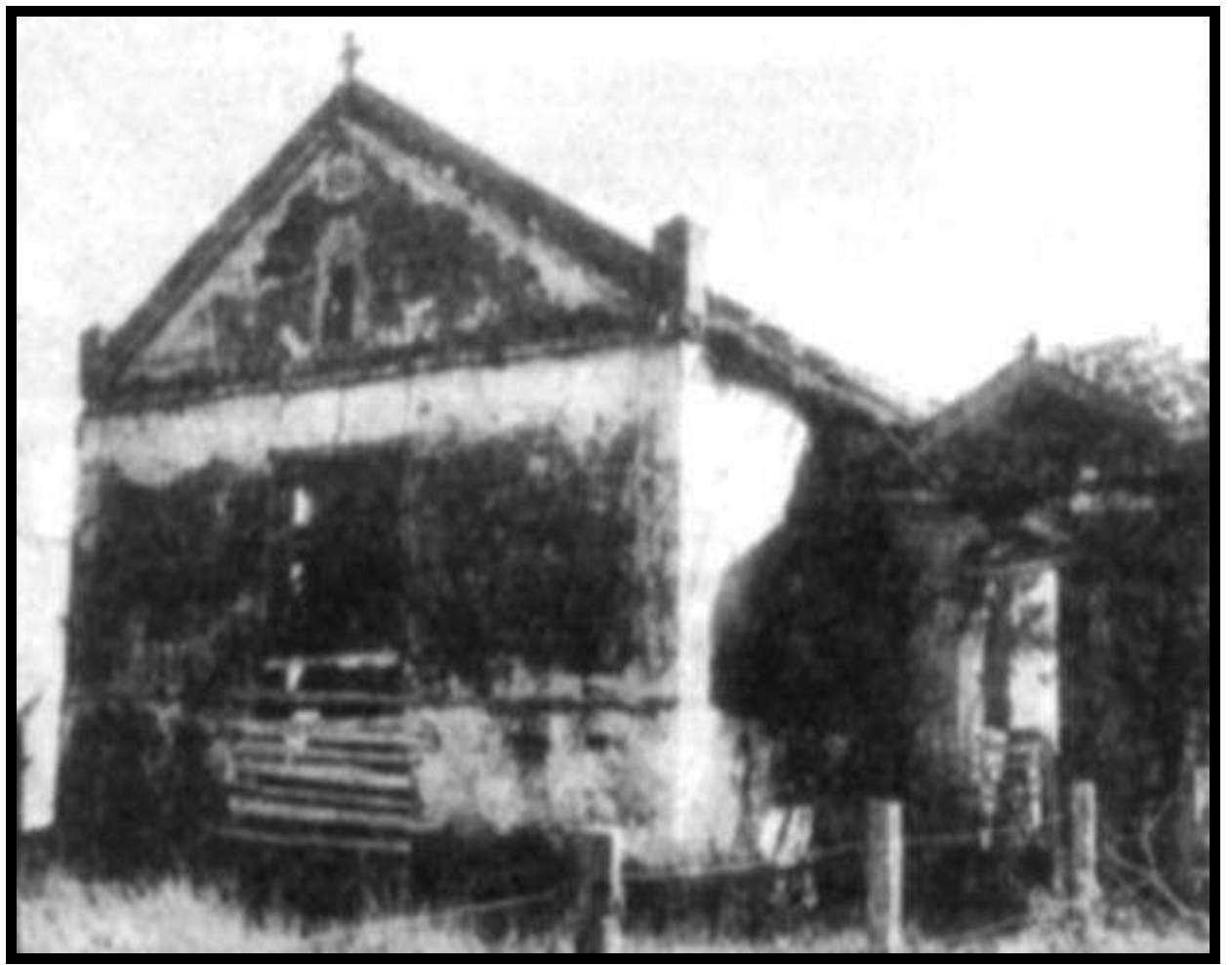

Disponível em: http://www.novomilenio.inf.br/pg/pgh007e.htm, acesso em: 29/12/2006, por Imário Vieira - Autor desconhecido

Estas são as ruínas da antiga capela que foi erigida em 1909, pelos antigos moradores do Boqueirão de Praia Grande. Ela não existe mais, em seu lugar, foi construída outra capela.

Dessa forma, com a construção da primeira capela da região, a população do distrito de Praia Grande tinha um lugar para comungar e se reunir. Acreditamos que o mesmo que aconteceu em outros lugares e povoados "desse Brasil e do mundo", também deve ter acontecido nessa região, ou seja, ao construírem uma capela, há uma tendência de seus habitantes em construírem suas moradias próximas às mesmas e como menciona o autor acima, esse fato, "o patrimônio religioso" decide o nascimento de um povoado e com certeza deve ter ajudado no crescimento do povoado da época. 
Foto 08 - Capela de Santo Antônio do Boqueirão

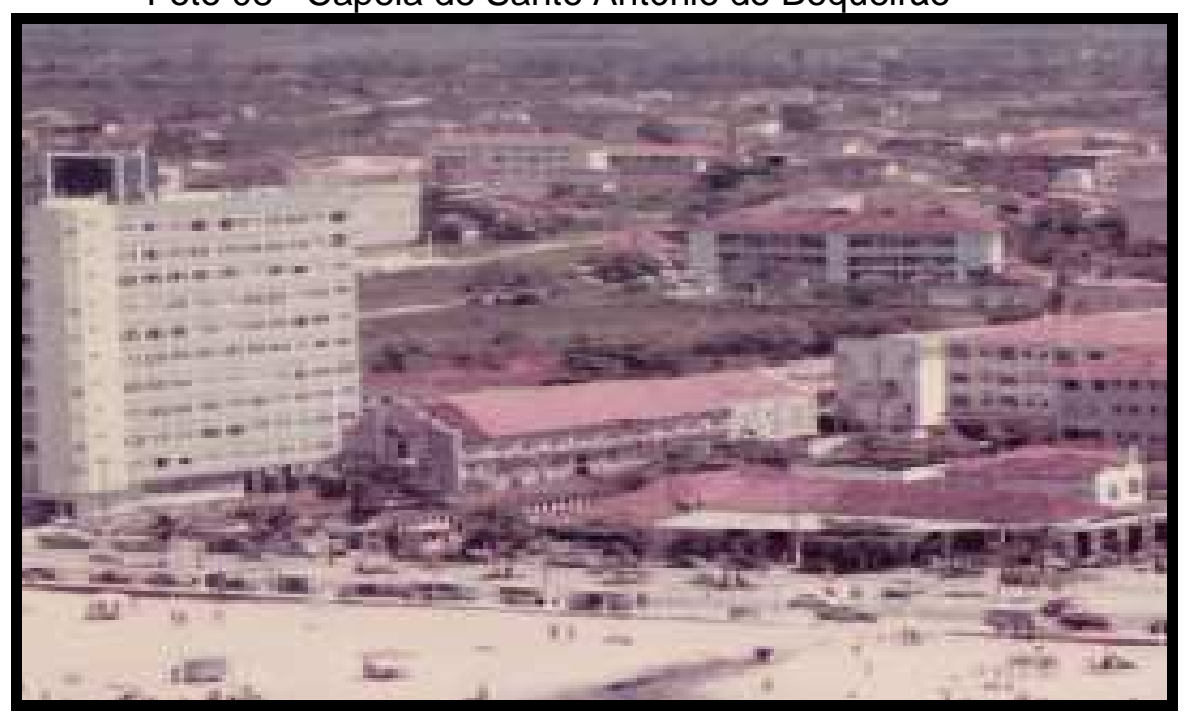

Fonte: Acervo pessoal de Dona Circe Sanchez Toschi.

Manipulada por: Imário Vieira - Autor desconhecido

Esta foto mostra a capela construída em substituição a de 1909 e que pegou fogo em 12 de outubro de 1997. Hoje em dia, no mesmo local, foi construída outra Igreja (também consagrada à Santo Antonio), a atual Igreja Matriz do município de Praia Grande. Também, vemos no canto esquerdo da foto um edifício com dez andares e com alguns edifícios de até 04 andares (ao fundo), construídos na década de 1950 e 1960.

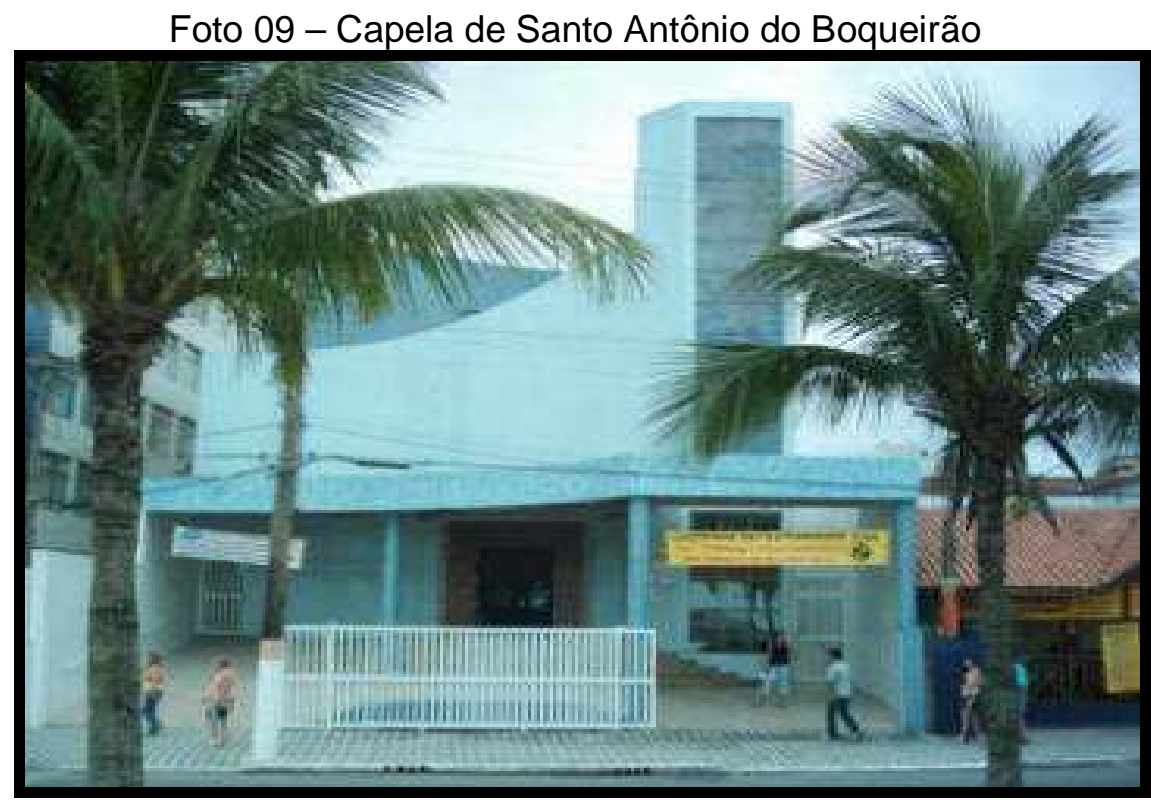

Fonte: Imário Vieira - Data: 24/03/2007 - Autor: Imário Vieira

Nessa foto, temos a atual Matriz de Praia Grande já reconstruída e no mesmo lugar em que se localizava a igreja que pegou fogo em 1997. 
Vale ressaltar que, em 1909, apesar da construção de sua primeira capela, Praia Grande era ainda um elo de ligação a quem se dirigia a Itanhaém. Em uma matéria, extraída do jornal A Tribuna (A TRIBUNA, Santos, 04 abr. 2004. Caderno Cidades, B-3 p.), vemos a confirmação desses fatos:

\begin{abstract}
"Em 1909, Praia Grande ainda era distrito de São Vicente e servia apenas como ponto de passagem para quem se dirigia a Itanhaem. Mesmo assim, a comunidade local decidiu construir uma pequena capela, que levou o nome de Santo Antonio.

A Igreja Matriz foi erguida somente em 1954, quando foi realizada a primeira missa ao ar livre. No dia 06 de julho de 1967, o local passou a ser a única paróquia da Cidade, ainda com o nome de Santo Antonio. Então, no dia 12 de outubro de 1997, um incêndio, durante a festa de Nossa Senhora Aparecida, destruiu o prédio, que agora esta sendo reconstruído de forma completamente diferente, mais moderno do que o projeto original".
\end{abstract}

Sendo assim, seguida da construção de sua primeira capela, em 1909, o Distrito de Praia Grande teve, em 1912, um outro fato importante que facilitou o seu crescimento e a circulação de sua região com as demais regiões litorâneas e do estado. Assim, com a construção da Estrada de Ferro Santos Juquiá, com o início de sua construção em 1912, esse meio de acesso ao Distrito de Praia Grande, também favoreceu o seu crescimento. Em relação a isso, Dona Circe Sanchez Toschi, antiga moradora da região, nos informa:

\begin{abstract}
"Em 1902, com início da construção da Fortaleza de Itaipu, a região registrou um período de crescente desenvolvimento. A construção da Estrada de Ferro Santos - Juquiá (1912) e, tempos depois, da Estrada de Ferro Sorocabana, também contribuíram para a formação do Município".
\end{abstract}

Além de Dona Circe, o arquiteto Eliseu de Andrade Júnior, também confirma a importância da construção da Fortaleza do Itaipu e subseqüente início da construção da estrada de ferro Santos Juquiá ${ }^{23}$, entre os anos de 1912-1915, ${ }^{23}$ Este ramal da Santos-Juquiá foi construído pelos ingleses da Southern São Paulo
Railway, entre 1912 e 1915, partindo de Santos e atingindo Juquiá. Em novembro de 
como fatos importantes para o crescimento de Praia Grande. Cabe se ressaltar que, essa estrada de ferro que, em 1927, passou a ser a Estrada de Ferro Sorocabana, hoje FEPASA, foi desativada em 2003. Em relação a esses fatos, Eliseu de Andrade Junior, como um dos conhecedores da história deste balneário, relata no jornal A Tribuna (A TRIBUNA, Santos de 24 abr. 1983. Especial Cidades. Capa), o seguinte:

\begin{abstract}
"Praia Grande praticamente não existia. Não tinha quase nada antes da inauguração da ponte. Tinha uma estradinha por onde eles traziam lenha de mangue para vender em São Vicente e Santos. Pouca gente morava por alí. (...) O efetivo surgimento do que hoje é Praia Grande começou em 1902, quando foi determinado o início da construção da Fortaleza do Itaipu. Logo depois, em 1912, começou a construção da Estrada de Ferro Santos-Juquiá, depois Estrada de Ferro Sorocabana e hoje absorvida pela Fepasa".
\end{abstract}

Continua a matéria,

“(...) o presidente do Estado de São Paulo ${ }^{24}$ foi até Praia Grande para presidir a solenidade de inauguração da estrada variante de acesso ao Forte, atualmente Avenida Marechal Mallet. A orla da praia, porém, apesar das estradas de ferro e de rodagem e do Forte permanecia intacta".

Assim, como nos relata o depoimento deste arquiteto e conhecedor da história de Praia Grande, pouca gente morava em sua região antes da construção da Fortaleza de Itaipu, da Ponte Pênsil e da Estrada de Ferro Santos-Juquiá. Quando o arquiteto diz que a orla permanecia intacta, acreditamos que estava se referindo à exploração imobiliária, pois no mesmo depoimento, ele menciona que poucas pessoas viviam ali, e mesmo antes da construção, já existiam em Praia Grande alguns sítios. Nessa época, o distrito de Praia Grande dependia

1927, o Governo do Estado de São Paulo comprou a linha e a entregou à Sorocabana, agora já estatal, no mês de dezembro do mesmo ano.

${ }^{24}$ Nesta época, o governador de um estado era chamado de presidente e quando o autor do artigo menciona "o presidente do Estado de São Paulo", está se referindo "ao governador do estado nos dias atuais". 
economicamente de São Vicente e Santos para a venda da lenha e de alguns produtos agrícolas produzidos em sua região. Vale lembrar que era também na região de Santos e São Vicente que os seus moradores compravam tudo aquilo que não podiam produzir em suas terras. Para todos aqueles que queriam chegar a Intanhaém, e demais localidades ao oeste do atual estado de São Paulo, Praia Grande era passagem obrigatória.

Nesse sentido, é provável que esta estradinha (ver foto 06 e figura 02) da qual falou em vida o arquiteto, seja a mesma, que ligava a Ponte Pênsil à Praia Grande, pois o caminho do Sítio Prainha, não era mais utilizado a partir da construção da Ponte Pênsil.

Figura 02 - Ligação entre a Ponte Pênsil e a Fortaleza do Itaipu (final da década de 1920)

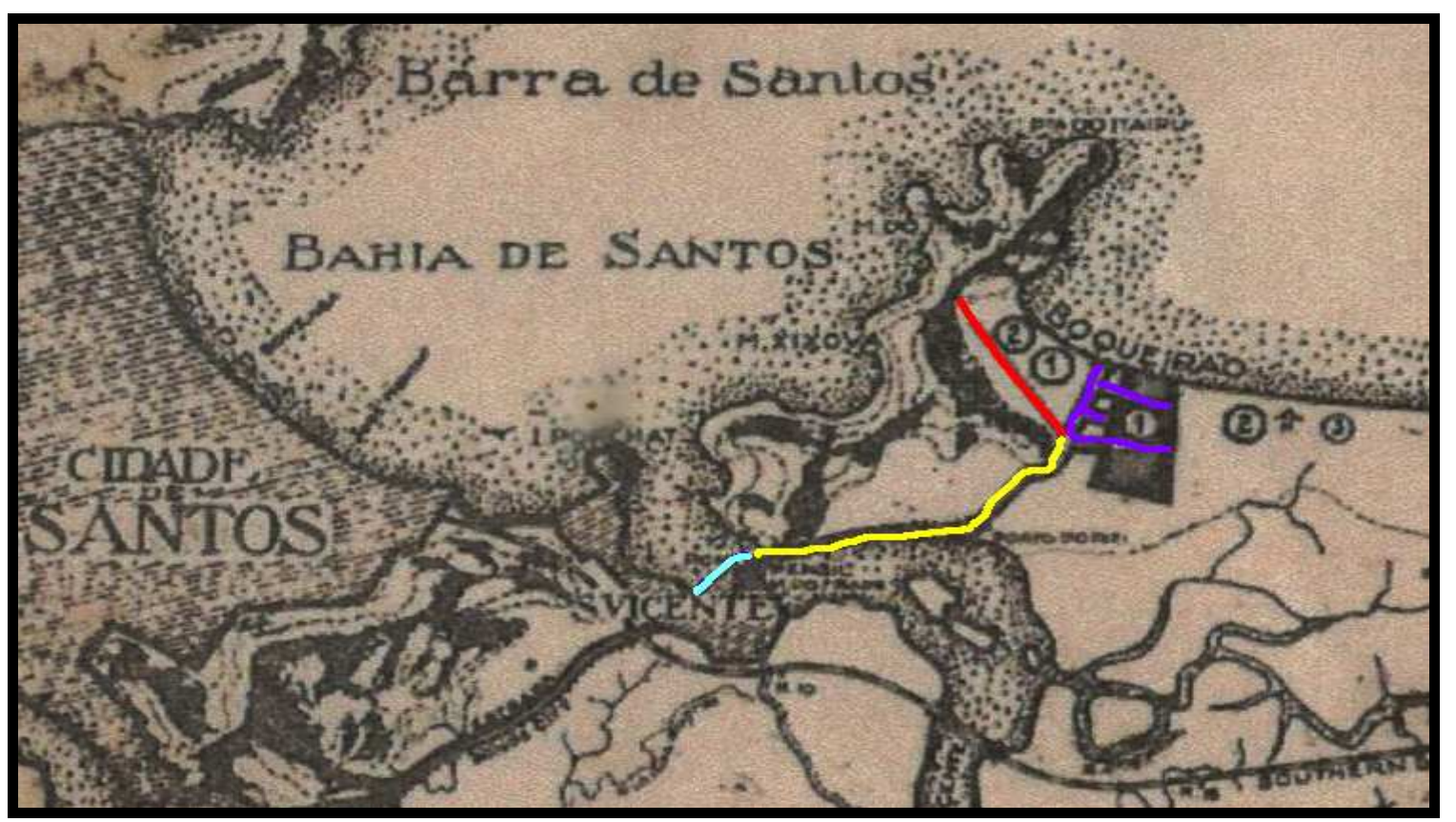

Fonte: Acervo particular de Dona Circe Sanchez Toschi. Adaptação: Imário Vieira

(Azul Claro) - Ponte Pênsil

(Amarelo) - Estradinha
( Vermelho) - Estrada Variante (Mal. Mallet)

(Roxo) - Arruamentos do Guilhermina

Este trecho acima foi extraído de um mapa elaborado pela Cia Territorial Jardim Guilhermina, mostra a Ponte Pênsil, a estradinha que saía da Ponte e que era ligada, em Praia Grande, a estrada variante (a atual Marechal Mallet). Vemos retratado no mesmo, os primeiros arruamentos do Jardim Guilhermina. 
Em 02 de julho de 1919, um viajante português relatou algumas viagens que fez às várias regiões do Brasil, entre elas, Praia Grande e nos conta que, na época (antes de 1914), passou por Praia Grande e que "não havia Ponte Pênsil ligando à essa cidade. A travessia do canal era feita por uma pequena balsa que era utilizada por poucos e servia para o transporte de mercadorias para Forte Itaipus ${ }^{25} \mathrm{e}$ para alguns pescadores da Praia Grande" (Disponível em: http://www.quata.com.br/conde/quarta.htm\#top, acesso em: 25/03/2006, por Imário Vieira).

Desse modo, como nos diz o relato, a travessia antes da Ponte Pênsil, era feita por balsas e utilizadas por poucas pessoas, em geral pelos poucos pescadores que habitavam a região e por aqueles que a utilizavam para chegar a Intanhaém. A partir da entrega da primeira bateria da Fortaleza do Itaipu em 1903, também eram utilizadas pelos militares e pessoas que abasteciam o forte com suprimentos e armamentos. Vale destacar que a atividade comercial realizada neste distrito de São Vicente, durante o princípio do século passado, ainda era muito incipiente, haja vista que, nesta época (1903), viviam poucas pessoas em Praia Grande e os meios de comunicação entre o distrito de São Vicente e demais regiões eram muito precários. Portanto, a necessidade de toda uma gama de "objetos técnicos" tornava-se necessária para o processo de urbanização de Praia Grande.

Exemplificando o fato acima, Dona Maria Blume ${ }^{26}$, que começou a vender doces aos motoristas que passavam pela Ponte Pênsil, a partir de 1916, nos diz em seu relato que, por volta de 1930, costumava contar quantos carros passavam por dia pela ponte, "mais ou menos uns 15 carros e muitas carroças, hoje está tudo diferente, passa tanto carro que não dá para contar".

\footnotetext{
${ }^{25}$ Nome que usou para se referir à Fortaleza do Itaipu.

${ }^{26} \mathrm{Em}$ 1916, dois anos depois de inauguração da ponte pênsil, dona Maria Blume, antiga moradora de São Vicente, catarinense de Joinville, abria à margem do Mar Pequeno, junto à ponte, sua casa de bananadas, doces caseiros e garapa. A casa era de sapé e dona Maria, junto com seu marido que ajudava na fabricação dos doces, vendia seus produtos de fabricação caseira a todos que passavam pela ponte. Sua vida de comerciante terminou em 1952, quando passou o ponto para seu filho (Disponível em: http://www.jangabrasil.com.br/revista/julho80/cp80007b.asp, acesso em 25/01/2006, por Imário Vieira).
} 
A população fixa da região de Praia Grande, até o início do século XX, era composta por caiçaras (ver fotos 10 e 11), que viviam da pesca e de pequenas culturas. Mas, aos poucos, essa realidade passou a ser mudada.

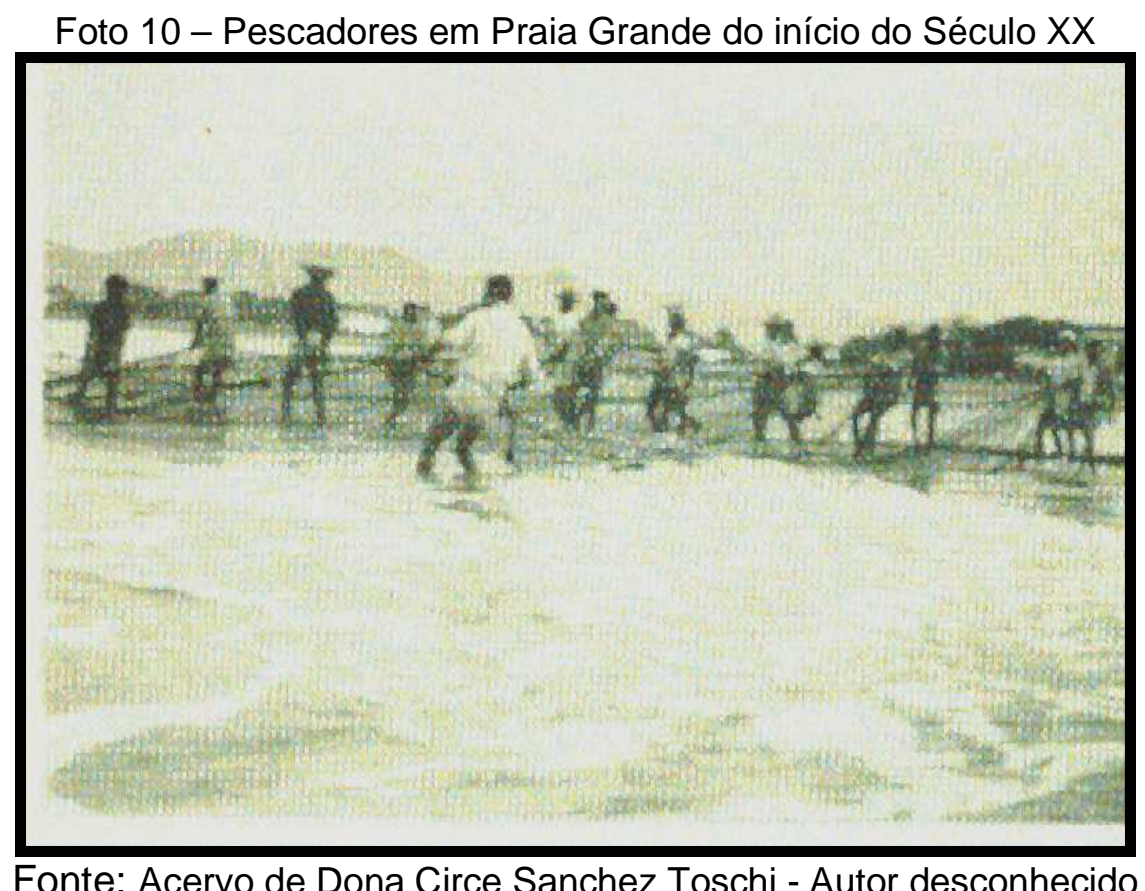

Foto de pescadores puxando a rede no princípio do Século XX. Nessa época, era atração turística ver os pescadores puxando suas longas redes que vinham repletas de peixes.

Cabe-se ressaltar que, foi a partir da construção da Ponte Pênsil e da Estrada Variante (atual Avenida Marechal Mallet), interligando Praia Grande a São Vicente e demais regiões, que o acesso foi facilitado e, aos poucos, a paisagem natural da região de Praia Grande começou a ser mudada. Com o crescimento de São Vicente em direção à Praia Grande, os loteamentos foram aparecendo próximos a esta estrada de acesso (Mal. Mallet) na região de Praia Grande e nas regiões que estão mais próximas a sua sede, São Vicente. 
Foto 11 - Pescadores em Praia Grande em maio de 1928

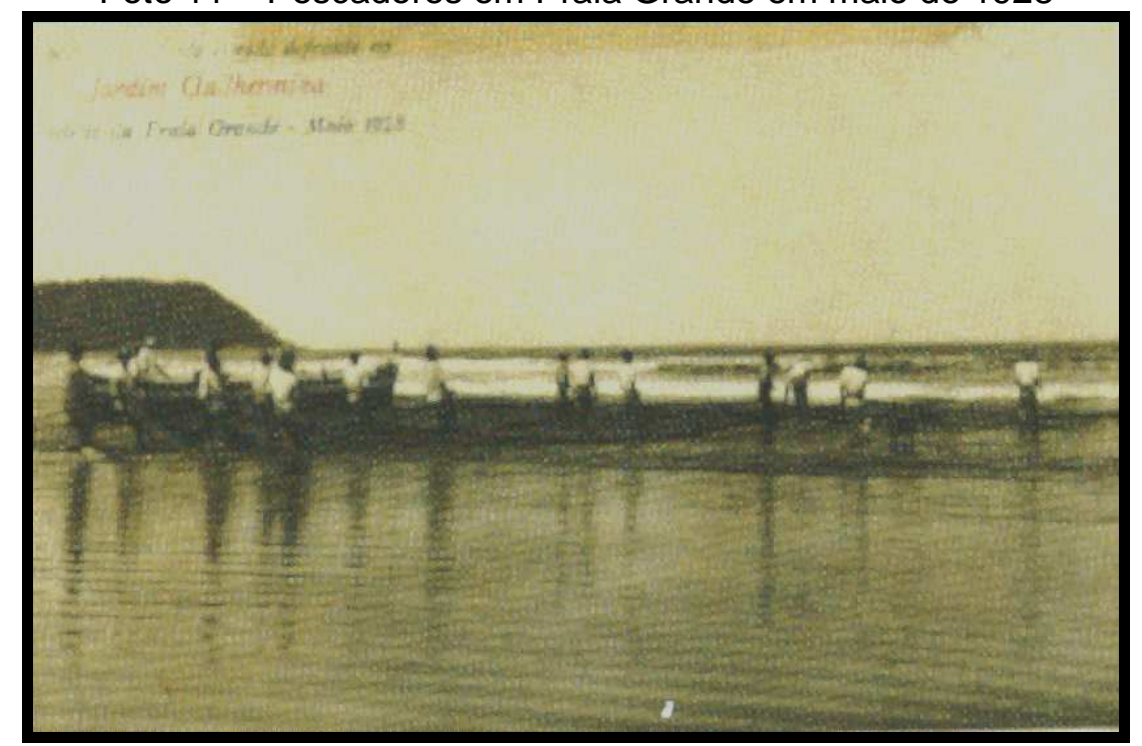

Fonte: Acervo de Dona Circe Sanchez Toschi - Autor desconhecido

Esta foto foi tirada em maio de 1928, a mesma mostra de um ângulo diferente, pescadores puxando suas extensas redes. Essa prática de lançar as redes, bem próxima à orla marítima, era muito comum no principio do século passado. Hoje em dia, a pescaria é feita através de barcos. Ainda nos dias atuais, é possível ver, bem cedo pela manhã, prováveis descendentes destes antigos pescadores da região de Praia Grande, retornando de suas pescarias.

Assim, quanto a infra-estrutura básica, na década de 1920, o Distrito de Praia Grande ainda deixava muito a desejar, em relação ao abastecimento de água, Dona Circe Sanchez Toschi nos relata que, na década de 1920, foi construído o Primeiro Reservatório de Água (ver foto 12) a partir de poço artesiano em Praia Grande. Ele visava o abastecimento do Jardim Guilhermina e foi terminado em 1928. No entanto, ela relata que, nesta década, houve uma crise epidêmica de "maleita" ${ }^{27}$ que atacou a região com a qual, segundo ela, muitos trabalhadores morreram vitimados por tal doença. Seu pai, Heitor Sanchez

\footnotetext{
${ }^{27} \mathrm{De}$ acordo com o Dicionário Wikepédia On-line (Disponível em: http://pt.wikipedia.org/wiki/Maleita, acesso em 23/01/2008, por Imário Vieira), o mesmo define Maleita como: um vocábulo, hoje em dia pouco usado, e que pode significar, qualquer doença em geral, especialmente as de menor gravidade; ou mais especificamente, maleita é o mesmo que malária.
} 
também pegou a tal maleita "e daí para a tuberculose foi um pulo". Heitor Sanchez teve que se ausentar de Praia Grande pelo período de dez anos, buscando a cura em Campos do Jordão e retornando à Praia Grande somente na década de quarenta.

Foto 12 - Poço artesiano e reservatório de água do Jardim Guilhermina

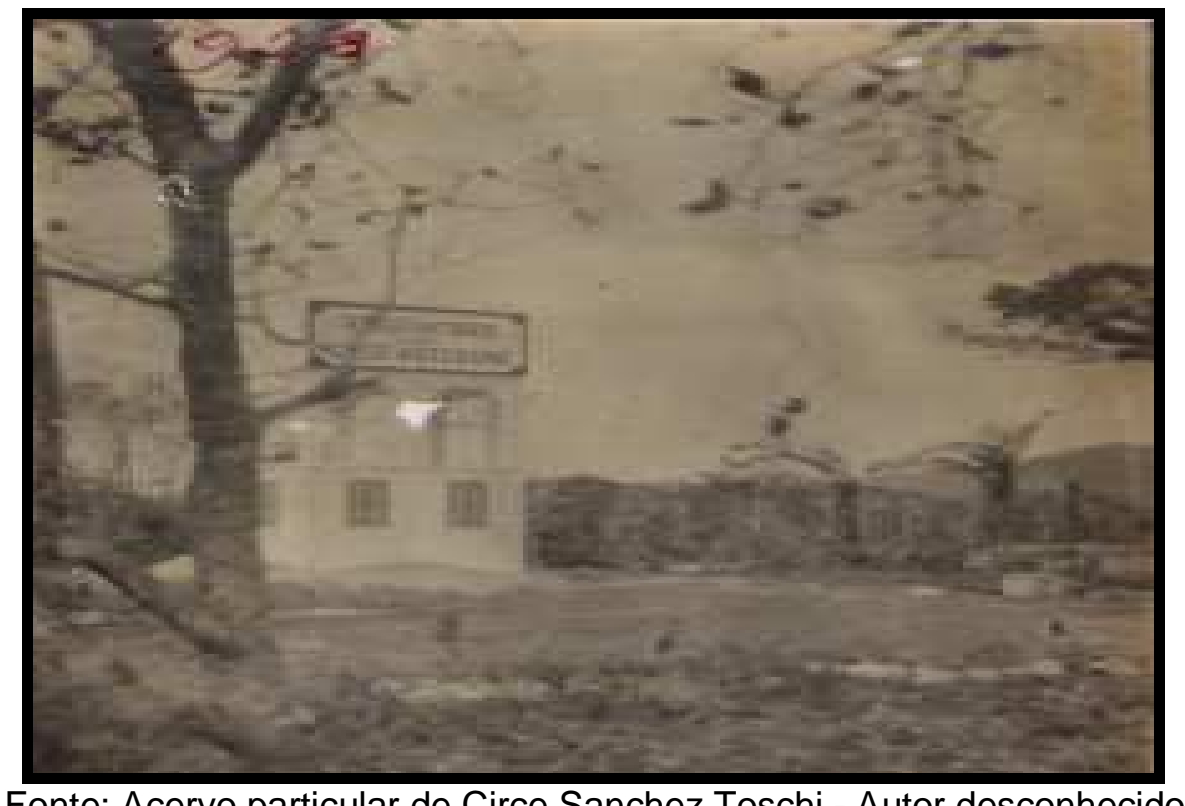

Fonte: Acervo particular de Circe Sanchez Toschi - Autor desconhecido

Este poço artesiano ajudou muito a abastecer o Jardim Guilhermina por um bom tempo, facilitando o abastecimento de água na região deste loteamento em Praia Grande.

Em 02 de maio de 1926, veio também a energia elétrica, fato marcante do início da ocupação mais recente daquele distrito vicentino (Praia Grande). Dona Circe Sanchez Toschi, entre as inúmeras fotos e documentos guardados ao longo de sua vida, também mantinha este registro fotográfico, com algumas famílias reunidas para uma foto que registraria a instalação da luz elétrica em 1926 (ver foto 13).

Desse modo, a partir da década de 1920, por meio dos agentes privados (indústria da construção civil) surgem os primeiros loteamentos e, em associação com os agentes públicos, vêm também, alguns arruamentos, o telefone, água encanada provindas de poços artesianos, cachoeiras e rios da região, bem como a energia elétrica com a iluminação de algumas ruas do Distrito de Praia Grande. 
Assim, a partir dessa década, a incipiente atividade agrária que existia na região praiagrandense tem os seus dias contados, pois o capital empregado nessa atividade primária migra para o do mercado de terras urbanas. Suzuki (1996, p. 164), ao falar da produção do espaço urbano e alterações no modo de vida da população de Rondonópolis, nos diz algo relevante que também se aplica ao caso de Praia Grande.

\begin{abstract}
"Dessa forma, percebe-se que o capital empregado nas atividades agrárias e comerciais migraram para o mercado de terras urbanas, já que, a longo prazo, o mercado de terras e edifícios não dá prejuízo. Esse movimento do capital condiciona, então, uma diversificação dos investimentos".
\end{abstract}

Continua o autor,

"(...) assim, a terra vai revelando, de forma mais contundente, sua faceta mais cruel, a de ser também mercadoria (...)".

Assim, com essa migração do capital de um setor para o outro, o Estado em comunhão com o capital vai modificando o uso e a apropriação do espaço e acaba induzindo à transferência de capital para regiões como a de Praia Grande e permitindo, com isso, um processo de reprodução do capital, viabilizando a produção de bens, de serviços, a circulação, a troca, o consumo e trazendo consigo um processo de mudança nas características de ocupação desta região de São Vicente, na vida social e econômica de seus residentes. Desse modo, aos poucos, com a mercantilização das terras e com novos investimentos chegando à cidade, a economia da região de Praia Grande vai migrando de agrícola para a indústria da construção civil.

Nesse sentido, é a partir da introdução do turismo de segunda residência e com a atuação da indústria de construção civil, junto com a infra-estrutura proporcionada pelos órgãos públicos e municipais de São Vicente, que a paisagem natural de Praia Grande vai sendo gradativamente transformada. Desse modo, o espaço em Praia Grande entra no circuito das trocas, é fragmentado e vendido em pedaços, sendo transformado em mercadoria e desencadeando um 
processo de valorização deste espaço e, com a especulação imobiliária, vai obrigando antigos proprietários a venderem suas pequenas propriedades, criando um aquecimento no mercado imobiliário da região.

Foto 13 - Foto comemorativa da inauguração da energia elétrica em Praia Grande em

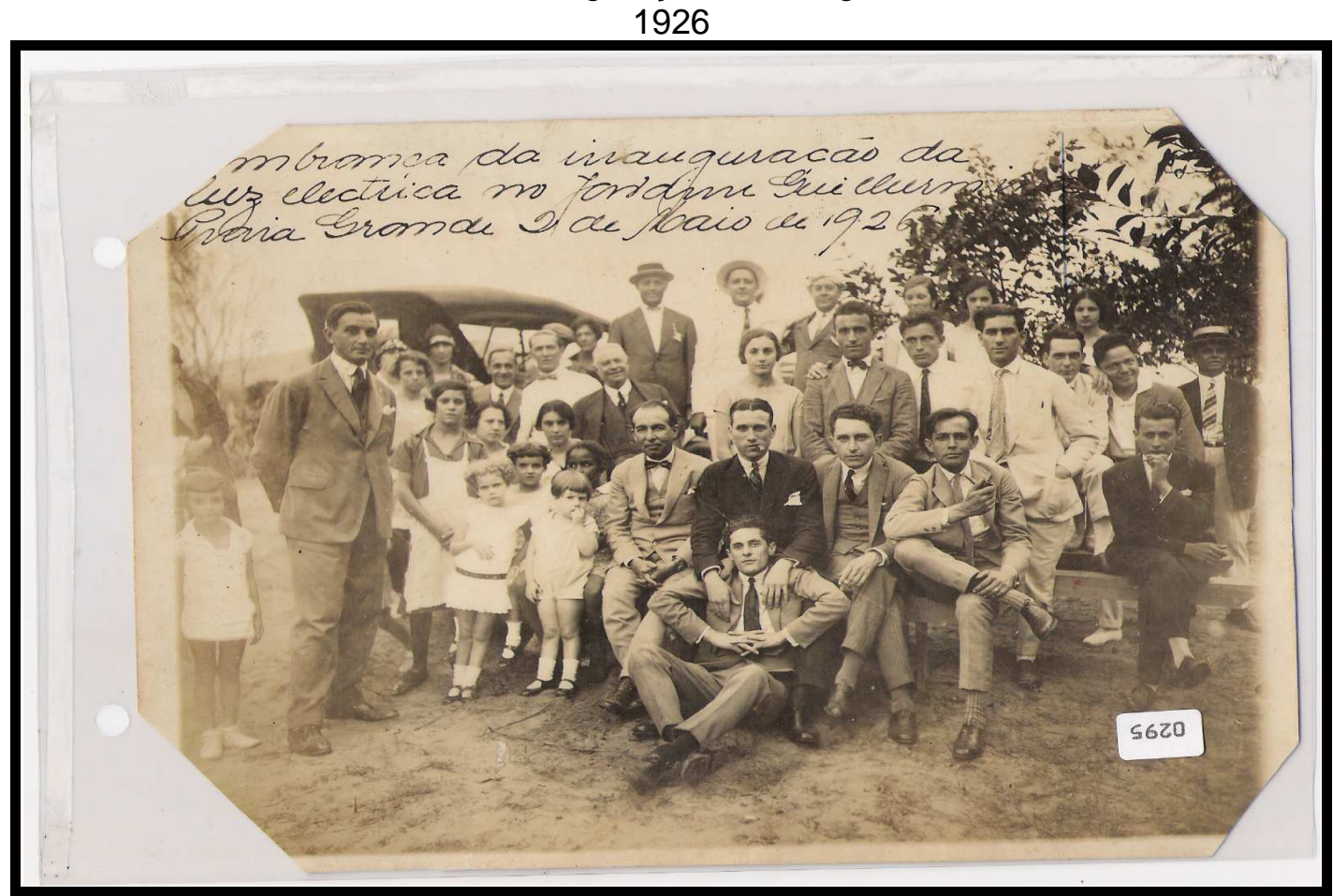

Fonte: Acervo particular de Circe Sanchez Toschi - Autor desconhecido

Nessa foto da inauguração da primeira ligação de energia elétrica em Praia Grande estiverem presentes várias famílias importantes para a história desta estância balneária, entre elas as famílias Toschi e Sanchez.

Assim, aos poucos, com o desenvolvimento da exploração do turismo de segunda residência, a economia local de Praia Grande passa a especializar-se na prestação de serviços, não só pela imposição dos pólos dominantes de sua região naquela época, mas também, pelo fato de não possuir condições favoráveis à expansão de atividades agrícolas e pecuárias, ou tampouco, à expansão de parques industriais. Algumas décadas mais tarde, tanto a região de Praia Grande, quanto uma grande parte da atual Região Metropolitana da Baixada Santista (RMBS), também seriam favorecidas com a criação do parque industrial e pólo petroquímico de Cubatão, e com uma crescente migração de mão-de-obra 
especializada para região. Dessa forma, também seriam favorecidas com um crescimento da demanda por moradias, aquecendo ainda mais o mercado da indústria da construção civil e ainda, promovendo uma absorção da mão-de-obra não especializada (caiçara) da região de Praia Grande e regiões vizinhas para atender a tais setores da indústria.

Cabe-se ressaltar que, foram essas gradativas e contínuas melhorias da infra-estrutura local por meio dos órgãos públicos e privados e, ainda, com o surgimento de uma nova atividade para a região - o turismo de segunda residência, que vão sendo desencadeadas mudanças profundas em Praia Grande.

Portanto, até a metade do século passado, e com um intenso parcelamento do solo, devido a uma acelerada demanda por segundas residências, criação de malha viária, aliados a expansão da rede rodoviária estadual e toda uma infraestrutura criada na região de ocupação mais antiga e mais próxima ao município de São Vicente, é que foi surgindo, o Sítio Urbano de Praia Grande.

\section{4 - O Sítio Urbano em Praia Grande e as regiões metropolitanas}

A Estância Balneária de Praia Grande é banhada pelo Oceano Atlântico e tem 22,5 km de praias. Está localizada no litoral sul do Estado de São Paulo e têm ao norte e ao leste, a cidade de São Vicente, ao sul o Oceano Atlântico e ao oeste, a cidade de Mongaguá (ver Mapa 01). Essa estância balneária conta hoje com doze praias sendo elas: Canto do Forte, Boqueirão, Guilhermina, Aviação, Tupi, Ocian, Mirim, Maracanã, Caiçara, Real, Flórida e Solemar.

Cabe-se ressaltar que, de acordo com dados oficias da prefeitura de Praia Grande (Disponível em:http://www.praiagrande.sp.gov.br/, acesso em: 22/01/2007, por Imário Vieira ), o balneário tem uma área territorial de $145 \mathrm{~km}^{2}$, uma altitude média de $5 \mathrm{~m}$., suas coordenadas são : Latitude: 24웅 $30^{\prime \prime} \mathrm{S}$ e Longitude: 46o 24' 45" W. Quanto ao clima, essa cidade-média, enquadra-se no sistema internacional de Koppen e tem as classificações AF e CFA, os quais são sucessivamente, $\mathrm{AF}=$ Clima tropical úmido, sem estação seca, sendo a temperatura média do mês mais quente superior a $18^{\circ} \mathrm{C}$. e a CFA = Clima mesotérmico úmido sem estiagem, em que a temperatura média do mês mais quente é superior a 22ํㅡ $\mathrm{C}$, apresentando no mês mais seco o clima tropical úmido, 
sem estação seca (Disponível em: http://www.novomilenio.inf.br/pg/index.html, acesso em 21/01/2007, por Imário Vieira. ). A temperatura média do balneário é de $27^{\circ} \mathrm{C}$.

Hoje em dia, é um lugar de fácil acesso, principalmente, por meio da nova pista da Rodovia dos Imigrantes (SP 160), inaugurada em 18 de dezembro de 2002. Outras rodovias de acesso (ver mapa 02) à cidade de Praia Grande são: Via Anchieta (SP 150), Rodovia Padre Manoel da Nóbrega (SP 55 - antiga Pedro Taques) e também Rodovia Régis Bittencourt (BR 116).

O seu sítio urbano está localizado do lado esquerdo das margens da Rodovia Padre Manuel da Nóbrega, a SP - 55 e entre as praias de Boqueirão e Aviação (ver foto 14).

Em relação à formação do sítio urbano em Praia Grande, Cíntia Maria Afonso (2006, p. 84) aponta,

\begin{abstract}
"tanto a ocupação inicial como a expansão urbana tem se dado por glebas, gerando um tecido urbano fragmentado, apesar de contínuo. E indicativa do loteamento por glebas a faixa urbana posterior à rodovia [Padre Manuel da Nóbrega], onde as áreas de ocupação esparsas mais recentes entremeiam áreas urbanas mais antigas e densas".
\end{abstract}

Essa ocupação inicial de expansão urbana, da qual nos fala a autora, é onde se encontra uma das regiões de loteamentos mais antiga dessa cidademédia paulista e, por coincidência, também é a área mais valorizada e de mais fácil acesso.

Dessa forma, a localização do seu sítio urbano está assentada em uma região muito favorável sob o ponto de vista topográfico para a expansão urbana devido ao fato do mesmo estar localizado em regiões planas e sem possuir acidentes desfavoráveis. Outro importante fato mencionado pela autora, é o de que sua ocupação, no princípio do século passado, deu-se por glebas, o que foi muito facilitado devido a essas condições topográfica favoráveis à expansão urbana. 
Mapa 01 - Localização da Estância Balneária de Praia Grande

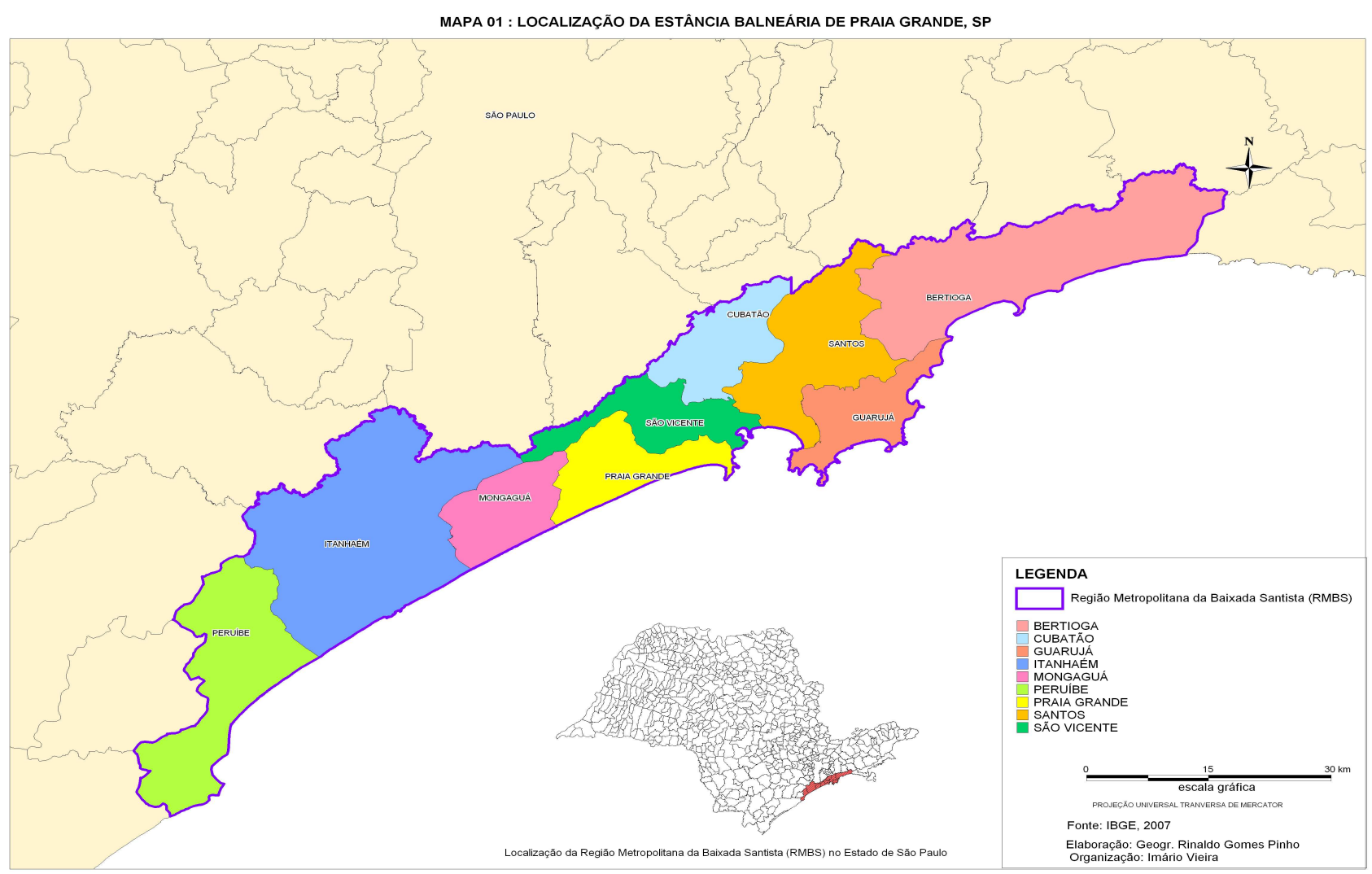

Fonte: IBGE, 2007 - Elaboração Geogr. Rinaldo Gomes Pinho 
Nesse sentido, Afonso (2006, p. 82), ao falar da região praiagrandense, nos informa que, "os terrenos planos junto às praias têm sido ocupados extensiva-

mente, gerando uma mancha urbana linear e contínua na faixa litorânea (...)".

Seu sítio urbano (ver foto 14) localiza-se em uma área que está mais próxima às cidades de Santos e São Vicente, a qual, no início da ocupação da região de Praia Grande, era muito carente de infra-estrutura viária.

Essa região do sítio urbano de Praia Grande possui diferentes traçados e tipos de malhas viárias com predominância do traçado ortogonal, do misto/ortogonal, do misto ortogonal/orgânico e de outros . Os variados formatos e malhas viárias mostram um parcelamento de solo, gleba a gleba, composta por um parcelamento concebido isoladamente, por isso, encontramos essa heterogeneidade de traçados viários (ver mapa 03).

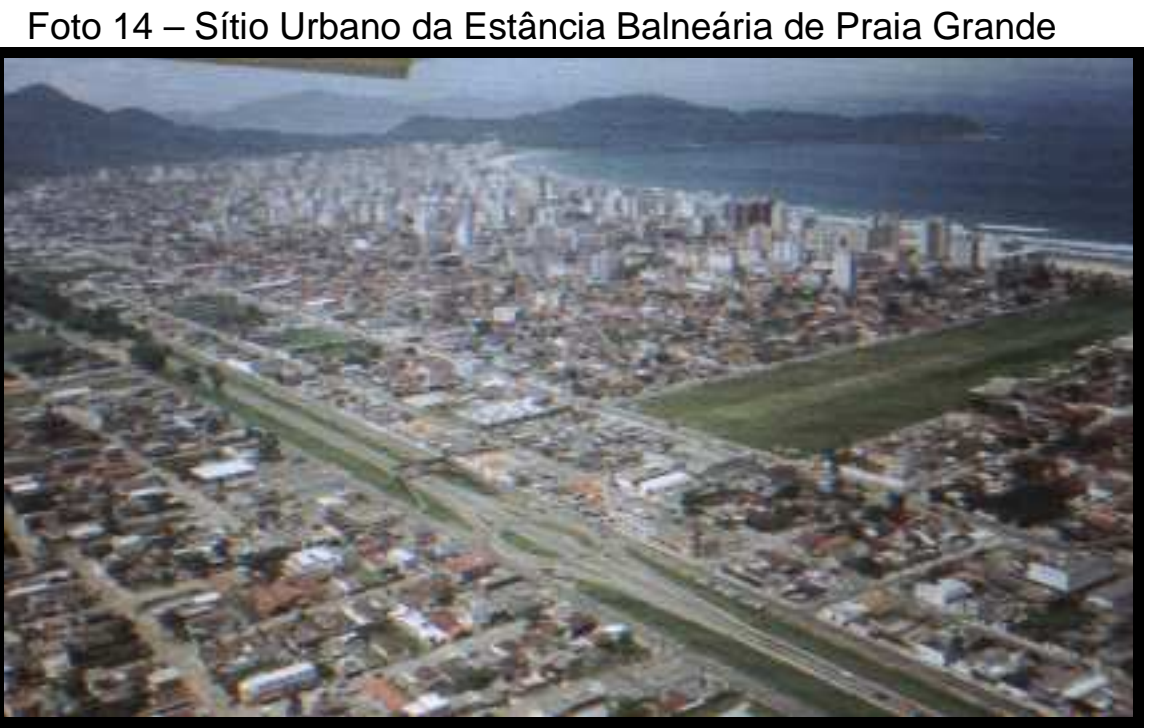

Fonte: AFONSO, Cíntia Maria. A paisagem da baixada santista: urbanização, transformação e conservação. São Paulo: Edusp, 2006, p. 84. Autor desconhecido

Essa fração do território, onde está localizado o Sítio Urbano de Praia Grande, localiza-se entre o lado esquerdo das margens da Rodovia Padre Manuel da Nóbrega, a SP - 55 (sentido Mongaguá) e o mar (compreende a região localizada entre as praias de Boqueirão e Aviação). Nessa área, há a predominância de verticalização, principalmente nas regiões mais próximas à orla marítima. 
Mapa 02 - A cidade de Praia Grande e sua ligação rodoviária com a Metrópole de São Paulo

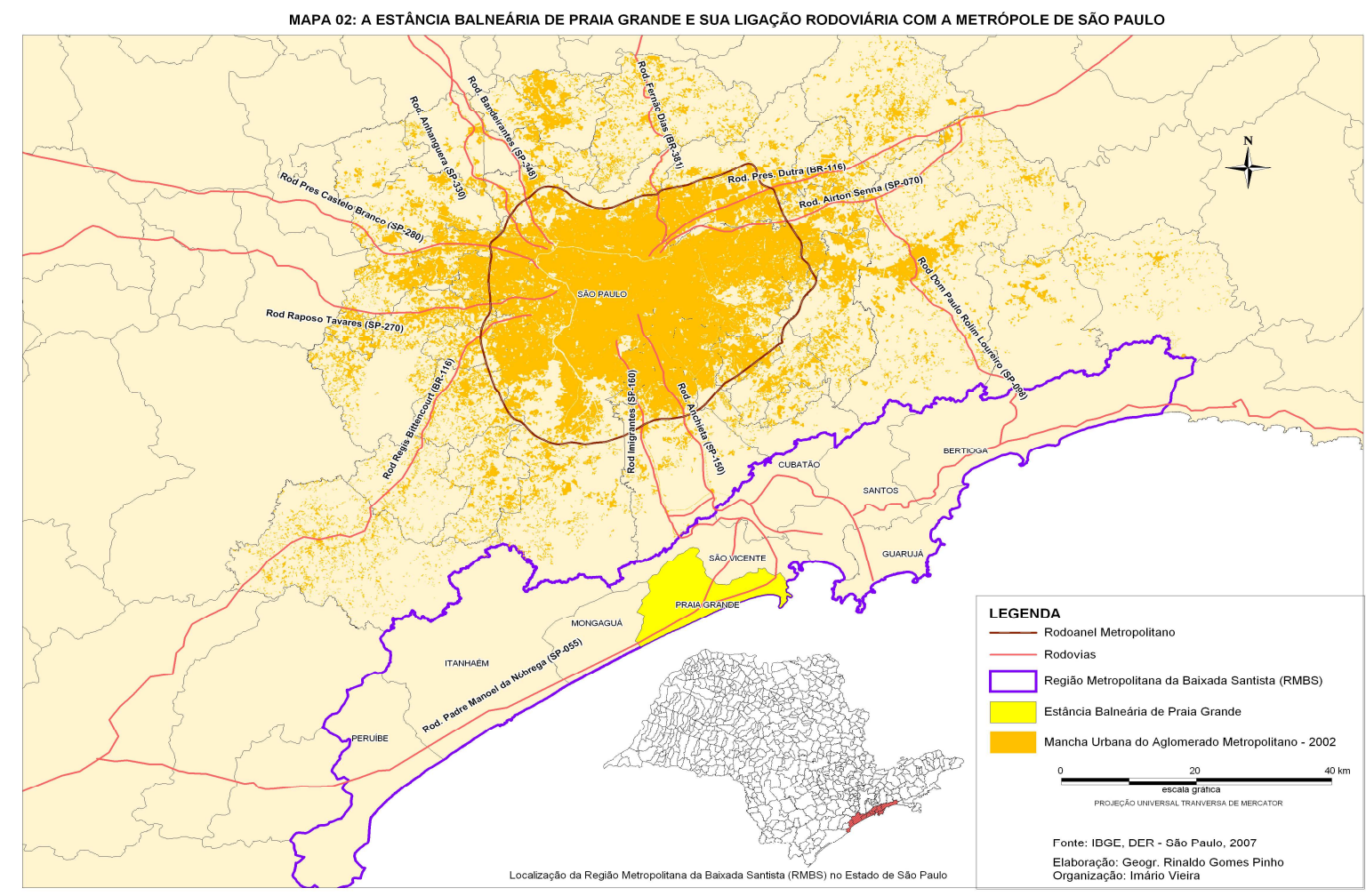

Fonte: IBGE,DER, São Paulo, 2007 - Elaboração Geogr. Rinaldo Gomes Pinho 
No entanto, a urbanização linear e seu processo de verticalização ocorre de forma contínua junto às praias e é, também, onde ocorre um adensamento mais intenso, que se estende por todo os seus $22,5 \mathrm{~km}$ de orla. Isso se deve ao turismo de segunda residência que privilegia a vista para o mar. Desse modo, como informa Afonso (2006, p. 204) "o mar e a praia assumem a função de parque urbano, e a via beira-mar é um pólo aglutinador da população e da urbanização."

Ressaltamos que a região mais carente e de baixa renda, em geral, encontra-se nas áreas residenciais ao lado direito (seguindo em direção a Mongaguá) da Rodovia SP 55, ou Padre Manoel da Nóbrega, e estende-se desde a região do Terminal Rodoviário Tude Bastos até o limite com a cidade de Mongaguá.

A Estância Balneária de Praia Grande está próxima a um dos maiores e mais importantes núcleos emissores do turismo do estado, o núcleo da Região Metropolitana da Grande São Paulo (RMSP). Hoje em dia, Praia Grande, faz parte da Região Metropolitana da Baixada Santista $(\mathrm{RMBS})^{28}$, a qual é composta por nove municípios da região e são elas: Bertioga, Cubatão, Guarujá, Itanhaém, Mongaguá, Peruíbe, Praia Grande, Santos e São Vicente.

Percebe-se, portanto que, a ligação da Estância Balneária de Praia Grande com as regiões metropolitanas é de suma importância para o seu crescimento e desenvolvimento, não só por meio do turismo e seus benefícios para a economia deste balneário, mas também pelos empregos que geram para os seus cidadãos na própria cidade e fora dela.

Nesse contexto, nosso levantamento, junto a uma parcela de 800 pessoas da população fixa e/ou permanente deste balneário (ver gráficos 01 e 02), apontou essa forte ligação nos níveis de empregos com as regiões metropolitanas mais próximas, a de Santos (RMBS) e de São Paulo (RMSP).

\footnotetext{
${ }^{28}$ A Região Metropolitana da Baixada Santista (RMBS) foi criada pela Lei Complementar no 815 , de 30/07/96, que estabelecia a região metropolitana e seu sistema de gestão, autorizando a instalação do Conselho de Desenvolvimento e a criação do Fundo Metropolitano e da Agência de Desenvolvimento Metropolitano para sua região. A região conta com 2.373 de quilômetros quadrados.
} 
Mapa 03 - Planta do Sítio Urbano da Estância Balnearia de Praia Grande, SP MAPA 3 : SÍTIO URBANO DA ESTÂNCIA BALNEÁRIA DE PRAIA GRANDE

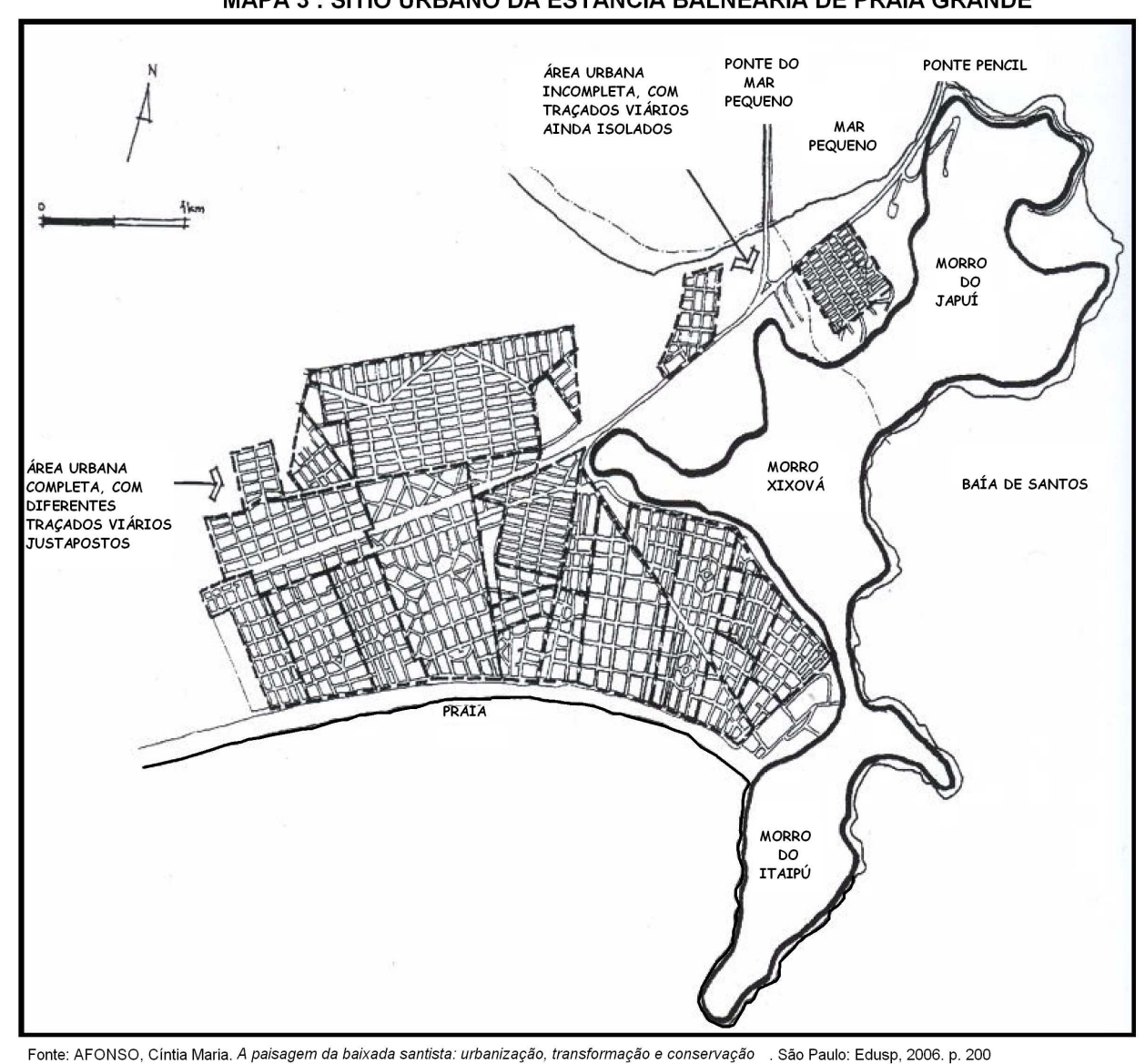

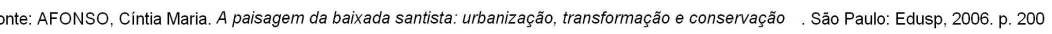


Desse modo, constatamos que quase a metade da amostra pesquisada $(45 \%)$ trabalha fora da cidade de Praia Grande, nas regiões metropolitanas da RMBS e RMSP. Somente 55\% dessa amostra trabalha na própria cidade (ver gráfico 01). No entanto, estes indicadores ganham maiores dimensões quando analisamos os resultados das pesquisas que fizemos junto a 1650 turistas (mais detalhes no Anexo A desta dissertação), ao longo das 12 praias desse balneário.

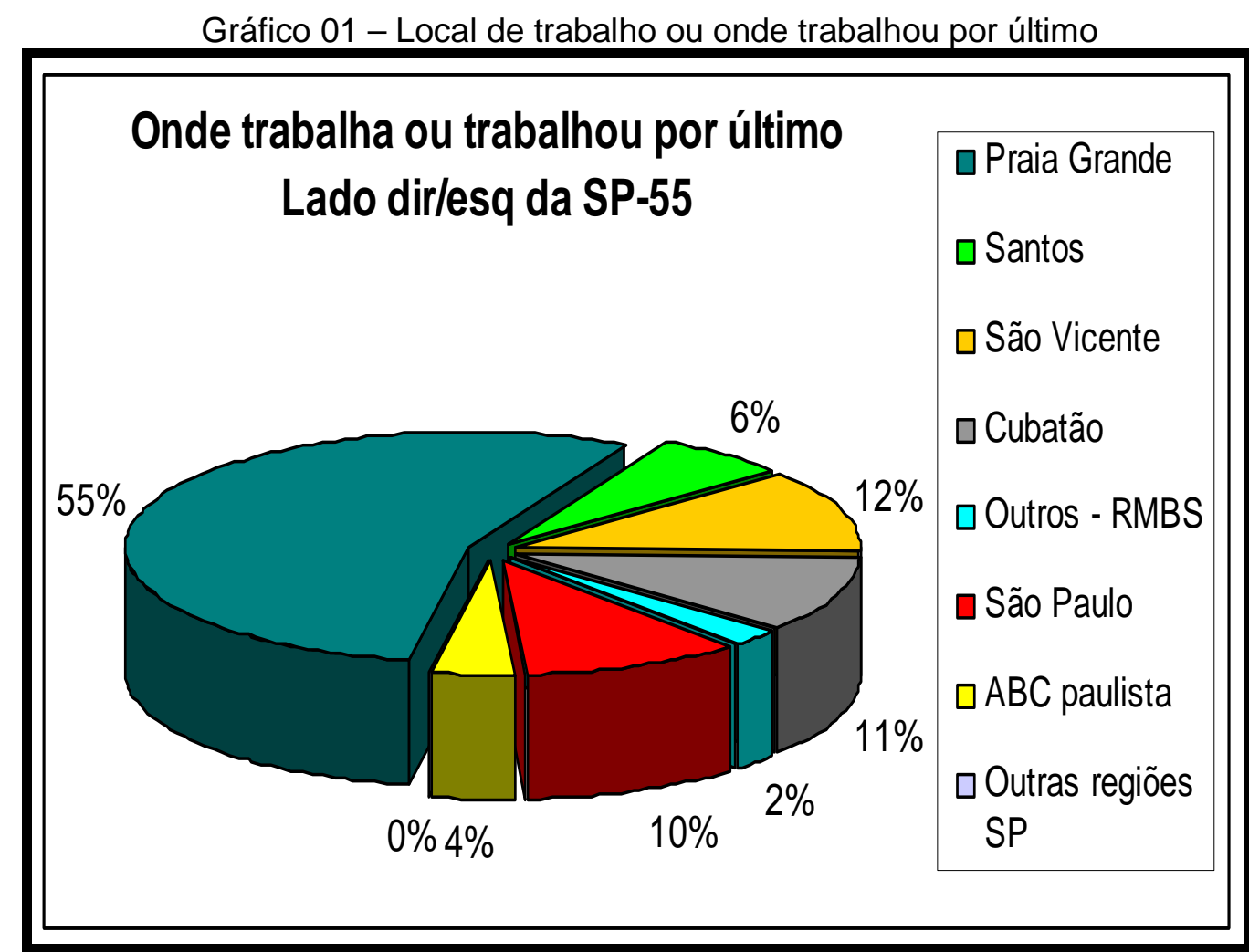

Fonte: Conforme trabalho de campo, realizado por Imário Vieira, entre os meses de maio e dezembro de 2007, especificamente nos dias 19/20/26/27 de maio, 30/Jun, 01/Jul, 04 e 05/Ago, 29 e 30/Set, 27 e 28/Out, 03 e 04/Nov, 01 e 02/Dez do ano de 2007. Elaborado por: Imário Vieira

Quando analisamos os dados referentes à procedência dos turistas que visitam o balneário de Praia Grande, vemos que 81\% são provenientes da RMSP, 4\% da RMBS, 7\% da RMC (Região Metropolitana de Campinas), 6\% são de 
outras regiões de nosso estado e $2 \%$ são turistas que são provenientes de outros estados (ver gráfico 02). Assim, estes dados mostram por si só, a importância da ligação que existe entre a Estância Balneária de Praia Grande e as diversas regiões metropolitanas e aglomerados urbanos do estado de São Paulo e de outros estados da federação.

Gráfico 02 - Procedência dos turistas em Praia Grande, SP

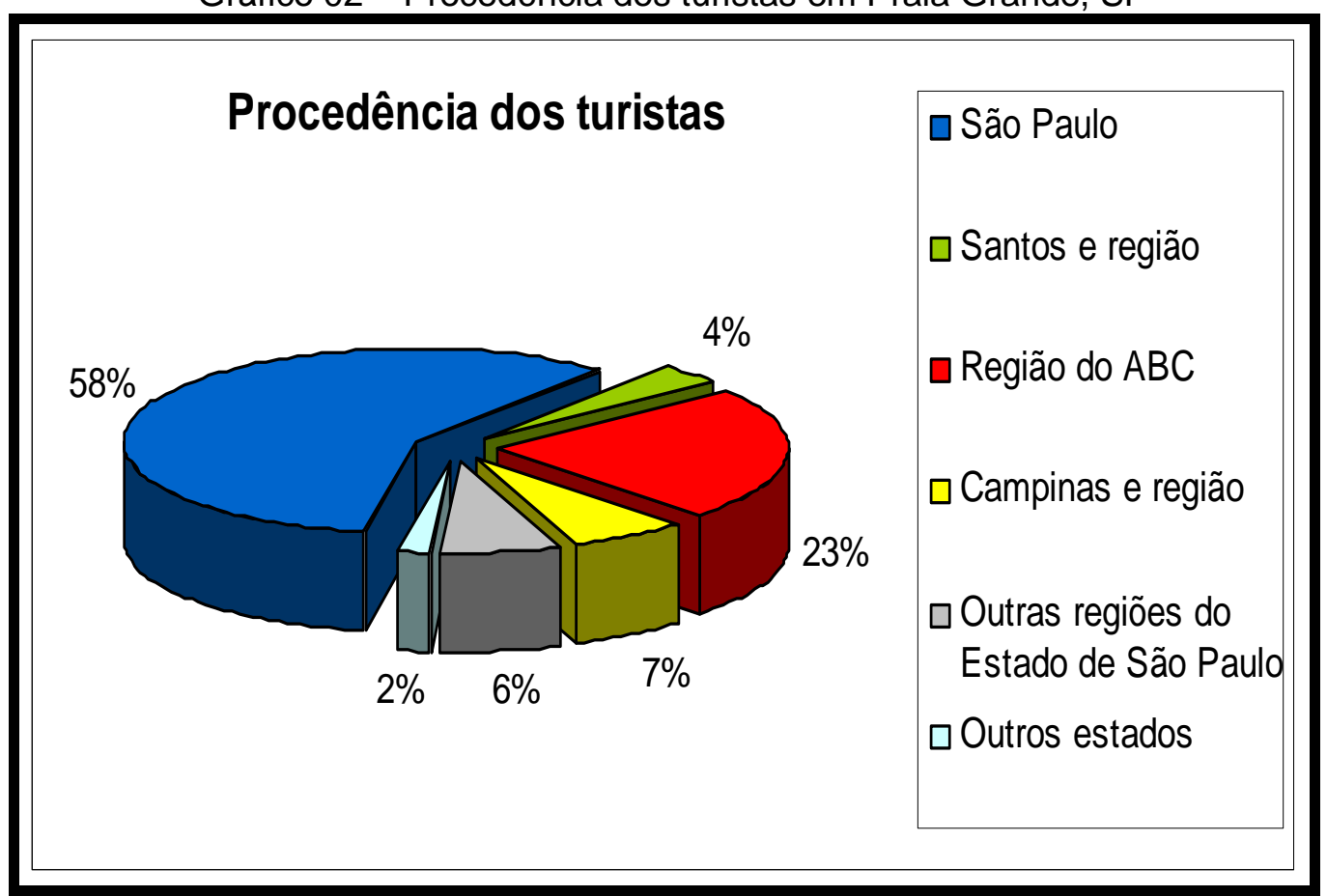

Fonte: Conforme trabalho de campo, realizado por Imário Vieira, entre os meses de junho de 2007 e janeiro de 2008, nos dias 07/08/09/10 de junho, dias 26/27/28/29 de julho, dias 18/19/20 de agosto, dias 07/08/09 de setembro, dias 12/13/14 de outubro, dias 02/24/25 de novembro, dias 01/02/21/22/23 de dezembro de 2007 e dias 04/05/06/17/18/19/20 de janeiro de 2008. Elaborado por: Imário Vieira 
Vale destacar que, de acordo com a EMPLASA ${ }^{29}$, a Região Metropolitana é apenas uma parte das várias regiões que temos no estado de São Paulo, e que tem como destino turístico, as regiões litorâneas.

A primeira região metropolitana a ser criada no estado foi a de São Paulo $(\mathrm{RMSP})^{30}$ em 1973. Essa região transformou-se nos dias atuais no pólo de maior rede urbana do estado e uma das mais importantes do país, cuja população, nos dias atuais, chega próxima dos 22 milhões de habitantes. Também é um grande centro de gestão de capitais.

A segunda região do estado a ser criada foi a Região Metropolitana da Baixada Santista (RMBS) em 1996, e hoje, conta com uma população que chega próxima dos 2 milhões de habitantes.

Dessa forma, verifica-se que a região da atual RMBS sempre esteve inserida no contexto do turismo do estado e do país, graças a grande diversidade de atrativos naturais, ecológicos, históricos, culturais, culinários, de esportes náuticos e outros. Sendo assim, entre tantos atrativos que temos no balneário de Praia Grande, podemos citar: as belezas naturais da Serra do Mar (que inclui os encantos da Mata Atlântica com sua fauna, flora, rios e cachoeiras), suas praias, extensos jardins e ciclovias junto à orla marítima, monumentos históricos, o circuito turístico dos fortes ${ }^{31}$, shows e eventos ao ar livre, uma diversidade de

${ }^{29}$ EMPLASA - Empresa Paulista de Planejamento Metropolitano S.A. É uma empresa que está vinculada à Secretaria de Estado dos Transportes Metropolitanos, constitui a entidade articuladora das políticas estaduais nas Regiões Metropolitanas do Estado de São Paulo.

${ }^{30}$ A Região Metropolitana de São Paulo, também conhecida como "Grande São Paulo", foi criada pela Lei Complementar Federal ํㅜ 14, de 8/6/73, e Lei Complementar Estadual no 94, de 29/5/74. A Região Metropolitana de São Paulo (RMSP), também conhecida como Grande São Paulo, reúne 39 municípios e são eles: Arujá, Barueri, Biritiba - Mirim, Cajamar, Caieiras, Carapicuíba, Cotia, Diadema, Embu, Embu-Guaçu, Ferraz de Vasconcelos, Francisco Morato, Franco da Rocha, Guararema, Itapeví, Itaquaquecetuba, Itapecerica da Serra, Jandira, Juquitiba, Mairiporã, Mauá, Mogi das Cruzes, Osasco, Pirapora do Bom Jesus, Poá, Ribeirão Pires, Rio Grande da Serra, Salesópolis, Santa Isabel, Santana de Parnaíba, Santo André, São Bernardo do Campo, São Caetano do Sul, São Lourenço da Serra, São Paulo, Suzano, Taboão da Serra e Vargem Grande Paulista. Estes municípios estão em intenso processo de conurbação, onde de acordo com IBGE (dados de 2005) vivem cerca de 20,5 milhões de habitantes com 8.501 quilômetros quadrados.

${ }^{31} \mathrm{O}$ Circuito Turístico dos Fortes foi elaborado em 2004 por meio de uma oficina de trabalho conduzida pelo SEBRAE - SP, com a participação de agentes públicos e 
esportes náuticos e radicais e tantos outros. Temos, ainda, sua proximidade com os maiores centros emissores do turismo do nosso estado.

Vale ressaltar que, com a criação da $\mathrm{AGEM}^{32}$ através da Lei Complementar Estadual № 853, de 23 de dezembro de 1998, a RMBS busca catalisar seus esforços rumo ao desenvolvimento conjunto de seus integrantes e, assim, conseguir uma maior competitividade na atração de turistas para região, aumentando suas chances na disputa com outros lugares turísticos do estado e do país.

E por fim, a terceira região a ser criada, foi a Região Metropolitana de Campinas $(\mathrm{RMC})^{33}$ em 2000 e conta com uma população em torno de 2,5 milhões de pessoas.

Assim, com o desenvolvimento das regiões metropolitanas e aglomerados urbanos do estado de São Paulo e no Brasil e, ainda, com a melhoria das condições econômicas e de vida das populações dessas regiões, principalmente a partir da segunda metade do século $X X$, cresce consideravelmente o número de turistas de segunda residência em busca de lazer litorâneo e de outras formas de lazer.

privados da região. O circuito conta com a visita a sete fortes/fortalezas e a casa do Trem Bélico e são eles: a Fortaleza do Itaipu (do século XX) em Praia Grande, a Casa do Trem Bélico (século XVIII) e Forte Augusto (século XVIII) em Santos, a Fortaleza de Santo Amaro da Barra Grande (século XVI), a Fortaleza do Itapema (século XVIII), Forte São Luiz (século XVIII) e o Forte dos Andradas (século XX) em Guarujá, e por fim, o Forte São João (século XVI) em Bertioga (vide mapa nos anexos desta dissertação).

32 AGEM - Agencia Metropolitana de Desenvolvimento da Baixada Santista.

${ }^{33}$ A Região Metropolitana de Campinas (RMC) foi criada pela Lei Complementar 870 de 19/06/00. É constituída por 19 municípios nas quais vivem perto de 2,5 milhões de pessoas com 3.673 quilômetros quadrados. Os municípios que fazem parte desta região metropolitana são: Americana, Arthur Nogueira, Campinas, Cosmópolis, Engenheiro Coelho, Holambra, Hortolândia, Indaiatuba, Itatiba, Jaguariúna, Monte Mor, Nova Odessa, Paulínia, Pedreira, Santa Bárbara d'Oeste, Santo Antônio de Posse, Sumaré, Valinhos e Vinhedo. 
Figura 04-Regiões metropolitanas, aglomerados e microrregiões do estado de São Paulo

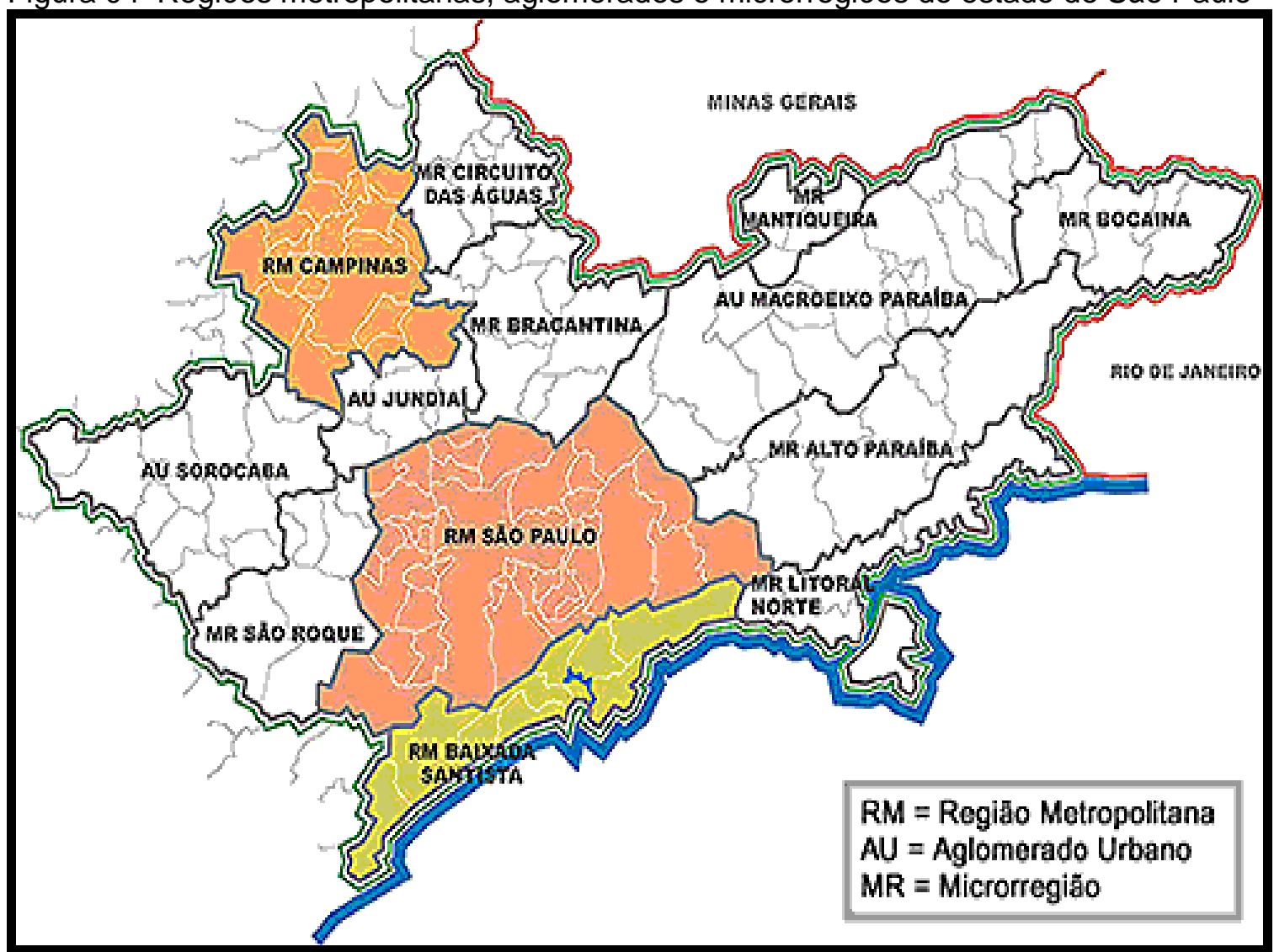

Fonte: IBGE, IGC, Secretaria de Estado e da Fazenda e Estimativa Emplasa - DIF/CIE Elaboração: Emplasa - CIE / CMC - 2002

Portanto, para falarmos sobre o turismo de segunda residência em Praia Grande e algumas especificidades da urbanização nessa cidade é necessário que compreendamos um pouco sobre o fenômeno do turismo, como ele surgiu no Mundo, no Brasil e nessa estância. 


\section{CAPÍTULO II - TURISMO, SUAS ORIGENS E A EXPLORAÇÃO IMOBILIÁRIA}

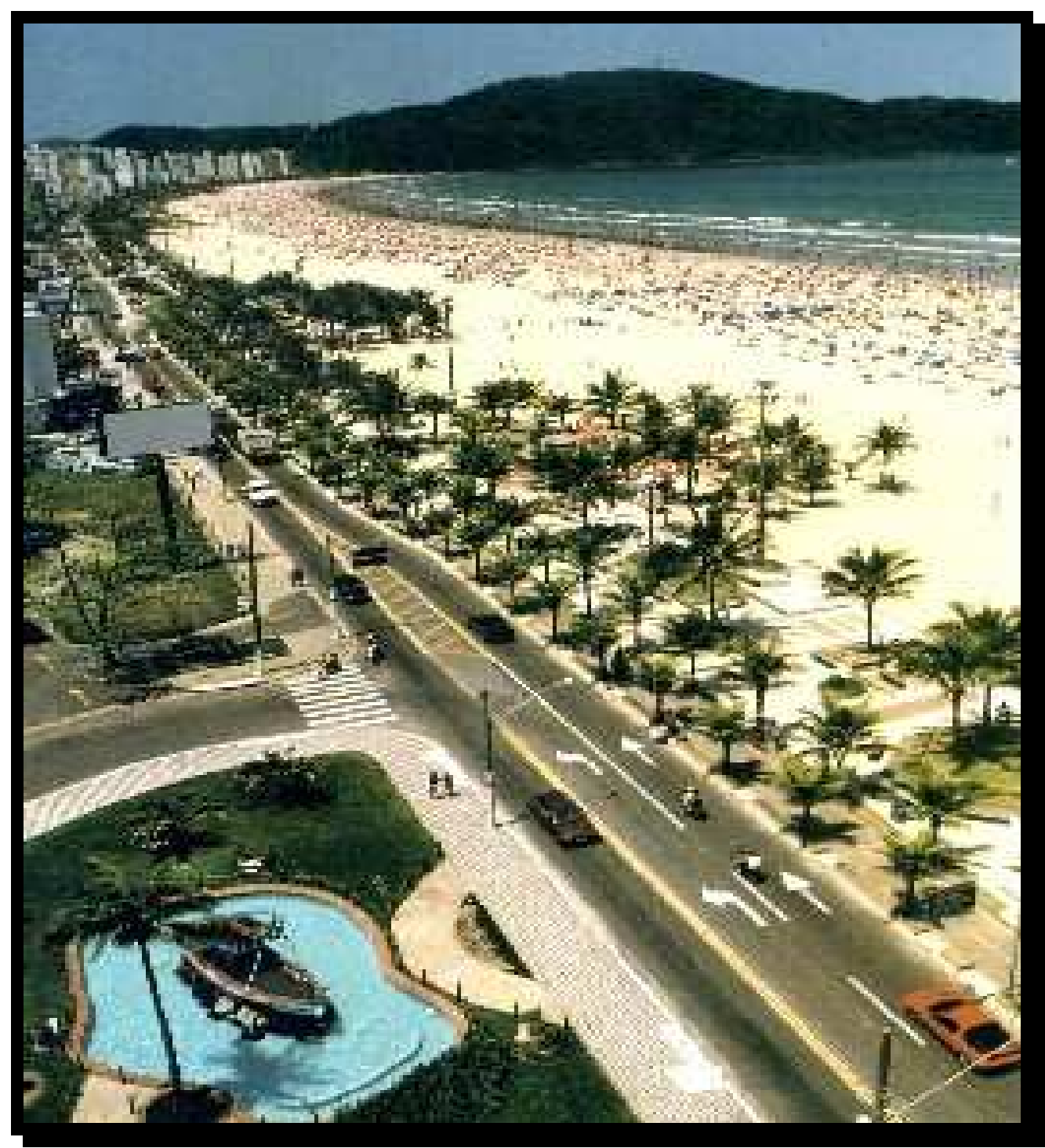


O interesse da geografia pelo turismo e seus efeitos na produção do espaço tem despertado nos geógrafos o desejo de estudar este fenômeno. Segundo Cruz (2003, p. v), este interesse da Geografia pelo turismo "já não é tão recente, assim como não são mais escassos como há poucos anos atrás os estudos realizados em torno do fenômeno do turismo". Complementando, Gómez (1988, p 46) diz que, já em 1905, Joseph Stradner introduziu na cidade de Graz, na Áustria, a expressão "Geografia do Turismo".

Para compreendermos como surgiu o fenômeno do turismo de segunda residência em Praia Grande, precisamos discorrer sobre alguns pontos importantes da história do turismo no Brasil e no mundo para um melhor entendimento de sua história, para então abordarmos o turismo de segunda residência na Estância Balneária de Praia Grande.

Nesse capítulo, também trataremos sobre a exploração imobiliária que começou em Praia Grande a partir da década de vinte com o surgimento do turismo de segunda residência em sua região. Com a descoberta de seus $22,5 \mathrm{~km}$ de belas praias pelas pessoas que visitavam a região no início do século passado, cria-se um valor em torno desse espaço e conseqüente interesse de investidores da área de exploração imobiliária devido ao fato desse lugar ter sido inventado como espaço turístico. Em relação a isso, Cruz (2003, p. 8) fundada em Knafou diz que "os lugares turísticos são inventados culturalmente e que, da mesma forma, são os atrativos turísticos e as paisagens turísticas". Sendo assim, com essa valorização para o turismo devido ao espaço turístico ter sido inventado culturalmente e com tantos fluxos de turistas que para lá se dirigiam, e ainda, aliado às vias de acesso facilitando o deslocamento para o balneário de Praia Grande, a exploração imobiliária, por meio do turismo de segunda residência, torna-se mais efetiva, surgindo a partir do início da década de 1920, os primeiros loteamentos. Sendo assim, iniciaremos com o turismo litorâneo e o banho de mar.

\section{1 - O turismo litorâneo e o banho de mar}

Dentre as várias opções do turismo, temos o turismo litorâneo. Segundo Lee (1998, p. 1), o litoral brasileiro, "se constituí cada vez mais em espaços, que 
podem se tornar atrativos para a atuação de atividades como a indústria da construção civil e o turismo". Mas o turismo litorâneo teve que passar por mudanças até alcançar os parâmetros dos dias atuais, pois o mar não era muito bem visto pela população de vários países antes do século XIX e XX.

Ao analisar o turismo, Dolffus (1991, p. 49) nos informa que o mar, até pouco tempo atrás, não era visto com bons olhos pelas populações do mundo afora como um lugar turístico. Foi somente a partir dos séculos XIX e XX, com o discurso terapêutico, que ele veio a ser inserido nos destinos turísticos das camadas sociais mais diversas. Ele continua em sua fala:

"O turismo causou mutações profundas, ele mudou nosso olhar sobre o mar, as montanhas, as paisagens, sobre os valores; os valores do ócio transmitiram-se através de gerações privilegiadas e foram transmitidas as 'estrelas' de todo tipo" (Dolffus, 1991, p. 46).

O turismo trouxe esse "admirável mundo novo", essa multiplicidade de mutações sobre valores dados a um determinado assunto ou lugar, mudando o nosso olhar sobre o mundo e os objetos nele contidos.

Dolffus (1991, p. 52) diz que o discurso médico ou higienista cobriu as grandes epidemias com a sua fé nas virtudes das águas e no seu valor terapêutico e estas afirmações, sendo repetidas constantemente, deram a essas práticas a difusão das estações balneárias, termais e também às montanhas, que até então, não tinham a busca desses lugares com estes novos fins que agora se propunham. Assim, ainda segundo o próprio autor (Dolffus, 1991, p. 55), "os turistas de massa eram percebidos então como consumidores da natureza, devoradores de paisagens", dando-nos um diferente enfoque do que vem a ser o turismo.

No entanto, esses modismos europeus acabaram por chegar ao Brasil, e aqui, também tiveram o mesmo "glamour". A procura por esses lugares onde pudessem ir e obter benefícios terapêuticos, ou ainda visitarem locais turísticos com suas belas paisagens naturais, transformou os turistas, como menciona Dolffus (1991, p. 55) em consumidores de natureza ou mesmo devoradores de paisagem. 
Dentro desse contexto, a introdução dos banhos de mar no Brasil tem sua história ligada a personagens famosos como o imperador D. João, que costumava tomar seus banhos de mar, dentro de um caixote especial, que ficava semimergulhado nas águas; assim também faziam D. Carlota e as filhas, tornando-se precursores do banho de mar no Brasil. Em relação à introdução dos banhos de mar no Brasil, Pires (2002, p. 56) nos relata:

"O início do prestígio das águas para a saúde e dos banhos de mar começou com a própria vinda da Família Real e, ao que parece, foram seus membros os maiores propagandistas, na proporção em que, por exemplo, outros integrantes do Palácio e a população em geral, se dispuseram a tomar águas minerais e banhos salgados. D. João, de hábitos caseiros e comodistas em Portugal - dizem que passou um ano sem sair do Palácio de Mafra - aqui se tornou um andante, vivendo de um lado para o outro a pretexto de tomar banhos de mar, ou indo ao Jardim Botânico, de que gostava muito. Quando se achava em São Cristóvão, tomava seus banhos no Caju”.

Mais adiante, em seu livro, Pires (2002, p. 57-58) registra:

"A grande voga de banhos de mar só começou, porém, por volta dos meados do século XIX, conseguindo atrair com bastante freqüência às praias centrais, como a do Boqueirão, em Santa Luzia. Consta que, por essa época, uma empresa explorou duas barcas especiais, forradas de cobre, divididas em camarotes, que dispunham de banheiro suspenso por correntes de ferro (...). A ligação entre os banhos salgados ou minerais com propriedades medicinais e, por isso, indicados para a cura de diversos males era, a bem verdade, um fenômeno mundial (...). Ao que parece, ainda no final da década de 1850, o banho de mar já havia se tornado um comércio bastante explorado".

Já os pesquisadores Macedo e Pellegrino (1996), ao contrário do que diz Pires (2002) afirmam que o banho de mar no Brasil é típico do século XX, apontando que em alguns lugares na Europa remontam ao século XV.

"O hábito dos banhos de mar é no Brasil típico do século XX, apesar de em alguns países europeus, como Inglaterra e França, remontar ao final do século XV. Tal hábito, à medida que se torna uma prática urbana, (...) se espalha pelos principais centros urbanos costeiros brasileiros e, a partir da segunda metade do século, por toda a costa do país" ( Macedo e Pellegrino, 1996, p.157). 
Sendo assim, quando Cruz (2003, p. 5) diz que "o conceito de turismo está longe de suscitar alguma unanimidade", vemos que o mesmo princípio se aplica à data do surgimento do turismo no Brasil. Estes dois autores, Macedo e Pellegrino (1996, p. 157), dizem que o banho de mar como uma prática urbana vai se enquadrando aos poucos, a partir da segunda metade do século $X X$, no cotidiano dos brasileiros de costa a costa.

Dessa forma, essa descoberta do banho de mar foi despertando, por toda costa do país, o interesse pelo turismo litorâneo e, para muitas cidades praianas brasileiras, representou o início de suas atividades turísticas e a Estância Balneária de Praia Grande, não foi uma exceção.

\section{2 - O início da atividade turística em Praia Grande}

Em Praia Grande, o interesse por suas belas praias e pelo banho de mar, num primeiro instante, mais acessível à população da região da baixada santista, tornou-se mais efetiva somente a partir da inauguração da Ponte Pênsil em 1914.

No entanto, o único problema que se fazia presente em Praia Grande, na primeira metade da década de vinte, era a falta de alojamentos que propiciassem uma maior estada em suas praias durante os finais de semana e feriados. A inauguração do seu primeiro hotel (veja foto 15) ocorreu somente em 1928.

Dona Circe Sanchez Toschi nos relata:

"Este hotel foi construído pelos proprietários do terreno, e também com investimentos com a Agencia da Cia Antártica de Bebidas em Santos. Assim foi possível levar a bom termo as conversações prévias, para ter um inquilino fixo, que pagaria como aluguel, ao juro de $8 \%$ ao ano, sobre 0 capital empregado na construção de um Hotel e Restaurante, que montava a 'cento e poucos contos de reis'.

A solenidade da inauguração teve lugar em julho de 1928. Até essa época, São Vicente não tinha nenhum hotel, somente pensões. Cinco residências, já haviam sido construídas para serem vendidas ao preço de dez contos de reis à longo prazo.

O Hotel custou 120.000.000, cento e vinte contos de reis, em julho de 1928". 
Percebendo essa demanda, Heitor Sanchez (pai de Dona Circe Sanchez Toschi) junto com membros da família Guinle e a Cia Antártica de Bebidas S.A., associaram-se e mandaram construir o primeiro hotel da região que chamaram de Hotel dos Alemães. Esse hotel foi inaugurado em 14 de julho de 1928 para atender a demanda de veranistas que para lá se dirigiam.

Foto 15 - Inauguração do Hotel dos Alemães construído em 1928

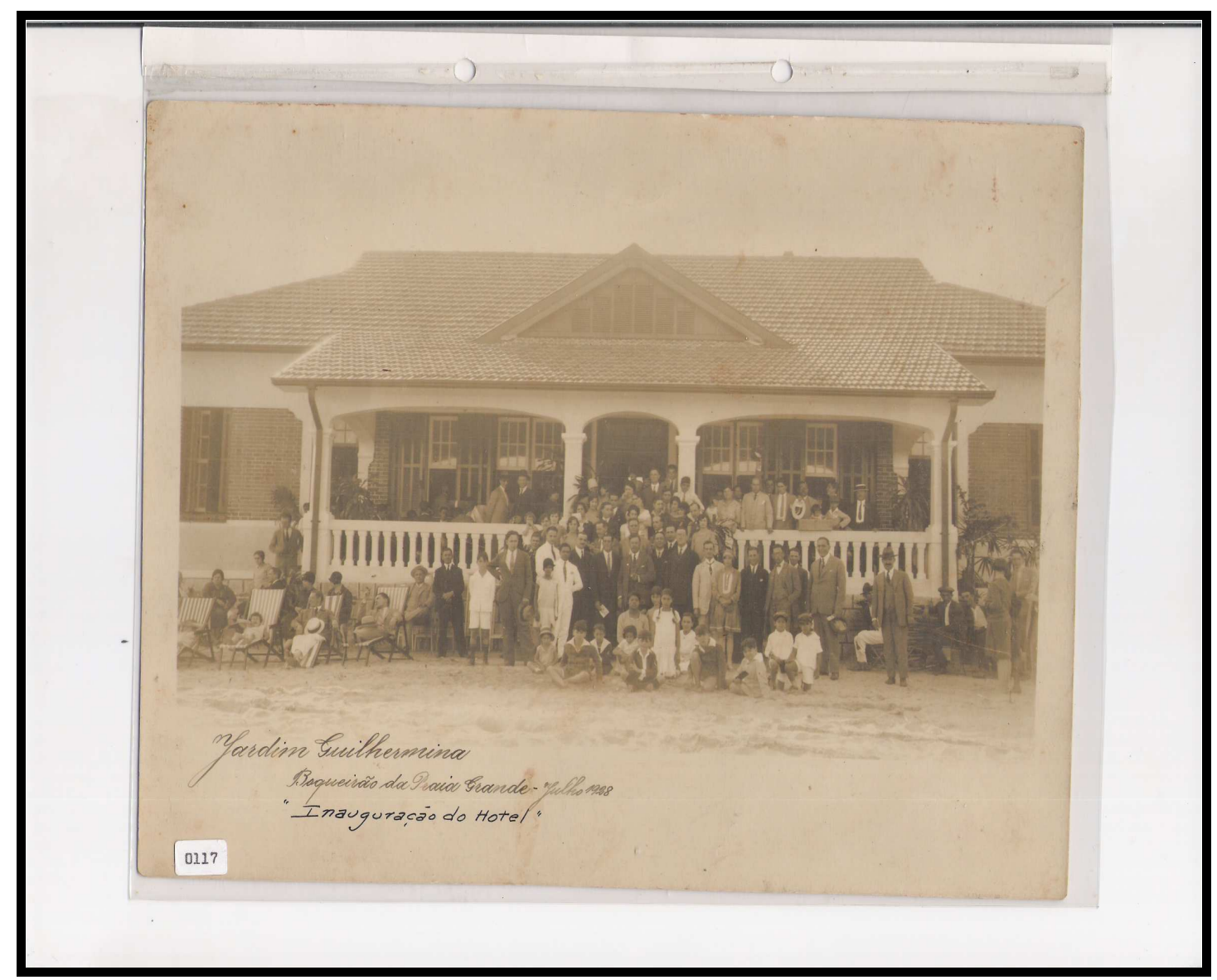

Fonte: Acervo particular de dona Circe Sanchez Toschi - Autor desconhecido

Esta cerimônia reuniu um bom contingente de pessoas influentes na história de Praia Grande, entre elas, alguns membros das famílias Sanchez e Toschi.

Nessa época, mesmo carente de infra-estrutura básica, o turismo, amparado pelas segundas residências, começa na região, com o loteamento dos terrenos. Esse hotel dispunha de várias cabines de banhos para utilização pelos turistas que se hospedavam e visitavam suas dependências (ver foto 16). 
Foto 16 - Hotel dos Alemães e suas cabines de banho em 1928.

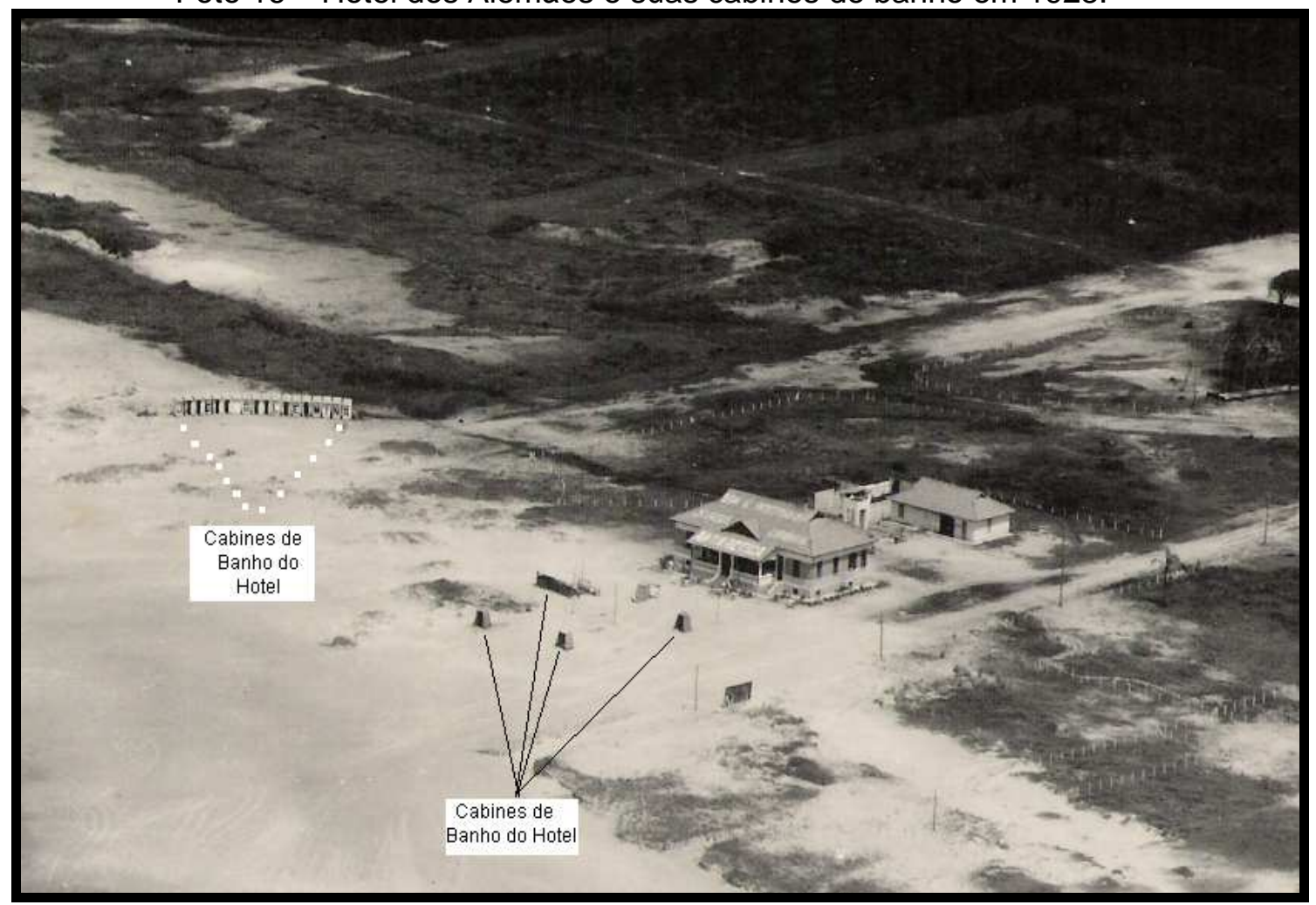

Fonte: Acervo particular da Dona Circe Sanchez Toschi - Adaptação: Imário Vieira Autor desconhecido

Esse hotel, chamado de Hotel dos Alemães, era dotado de várias cabines de banho do lado de fora de seu estabelecimento. No princípio do século passado, ele foi o primeiro hotel na região de Praia Grande, sendo um marco para o turismo na região. Tinha sua localização, dentro de um dos primeiros loteamentos destinados à segunda residência de Praia Grande, o "Jardim Guilhermina", e possibilitava a hospedagem aos turistas que vinham visitar suas praias, os quais acabavam por visitar os lotes que estavam à venda.

Assim, foi nessa época que Praia Grande teve a propaganda (ver figura 05 e 06) desse seu primeiro hotel - conhecido, até então, como pensão familiar - , por meio da distribuição de panfletos para toda a região da Baixada Santista e adjacências; tempos depois, seria mais conhecido como "Hotel dos Alemães".

Essa propaganda foi contratada pelo o Sr. Roberto Kock, arrendatário do Hotel $^{34}$ e, a título de curiosidade, vale informar que em seus panfletos, o Sr. Kock

\footnotetext{
${ }^{34} \mathrm{O}$ termo usado na propaganda era o de "pensão" e não de Hotel dos Alemães como ficou mais tarde conhecido e reconhecido pelos turistas que o visitavam.
} 
fez até propaganda de bebidas de um dos sócios proprietários desse hotel ( a Cia Antártica de Bebidas S.A.).

Figura 05 - Propaganda do Hotel dos Alemães (frente)

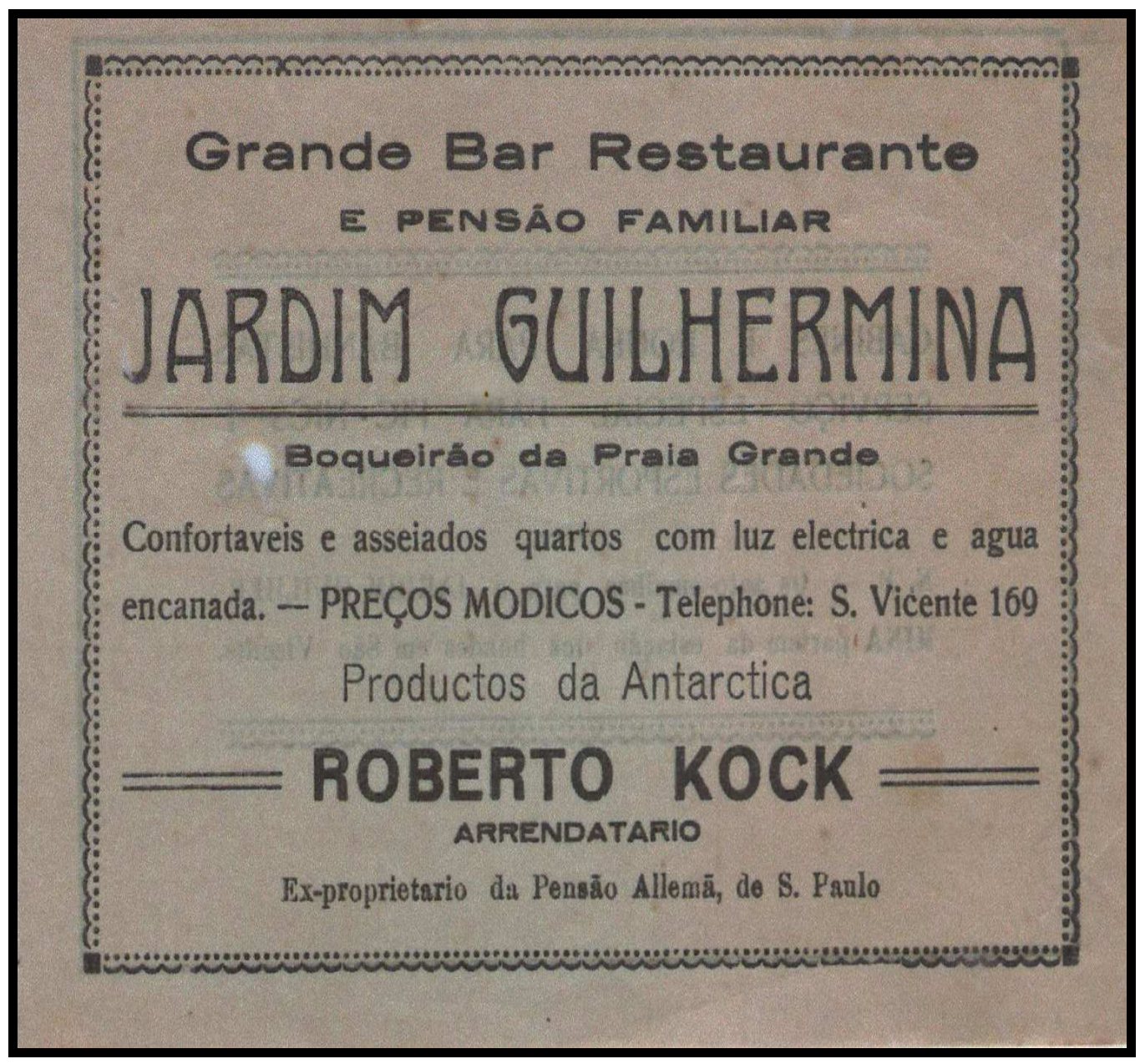

Fonte: Acervo particular de Dona Circe Sanchez Toschi

O panfleto acima descrevia o Hotel dos Alemães, como "Grande Bar e Restaurante e Pensão Familiar". Essa pensão estava localizada no Jardim Guilhermina e a mesma passou a ser conhecida como Hotel dos Alemães. Isso aconteceu devido ao fato de seu arrendatário, Roberto Kock, ter sido ex-proprietário da Pensão Alemã, na cidade de São Paulo. Essa primeira pensão na região de Praia Grande era descrita como tendo confortáveis e asseados quartos com luz elétrica, telefone, água encanada e ainda produtos da Cia Antárctica de Bebidas (um dos sócios na construção da mesma). 
Figura 06 - Propaganda do Hotel dos Alemães (Verso)

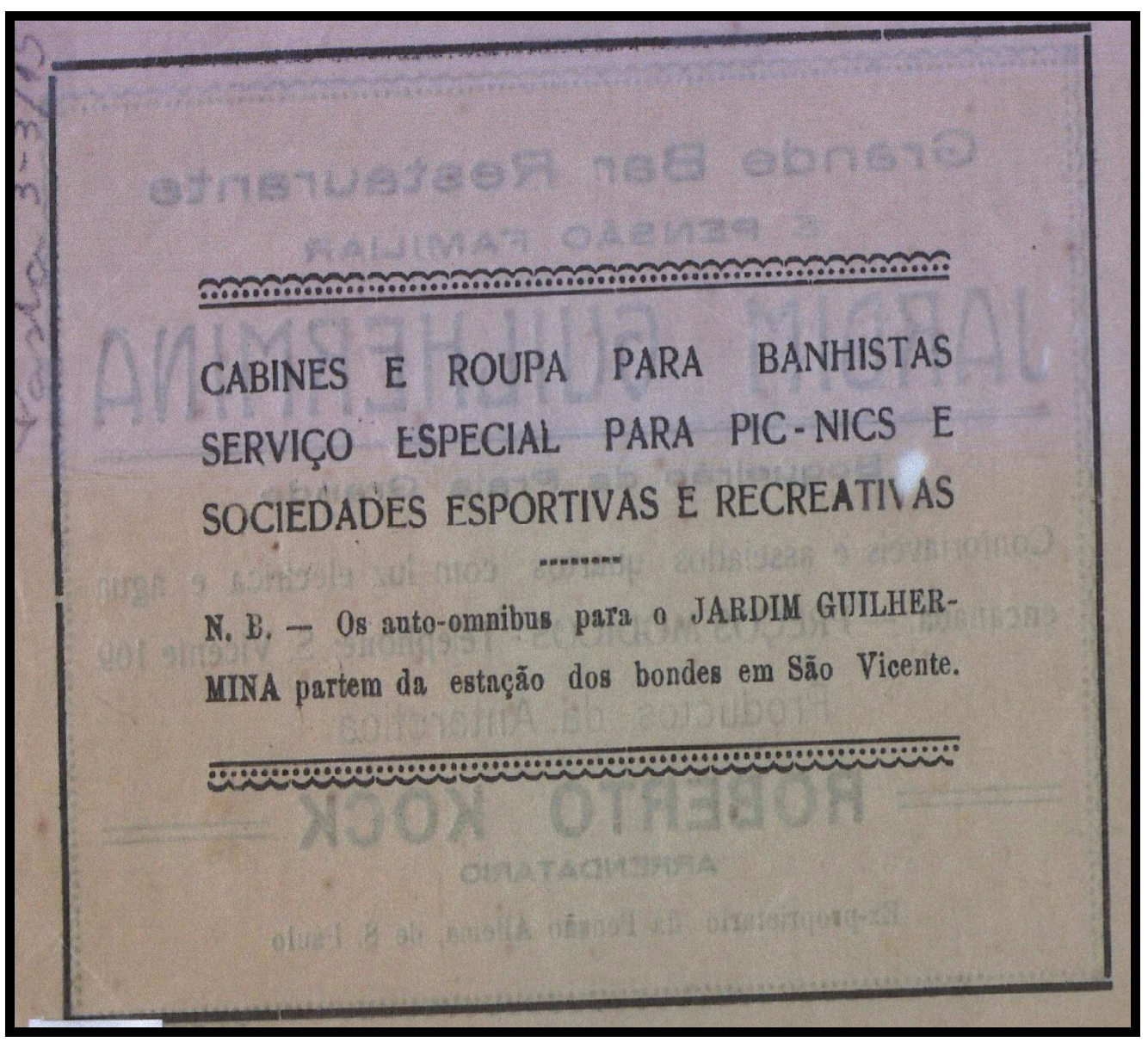

Fonte: Acervo particular de Dona Circe Sanchez Toschi

Essa pensão dispunha de várias cabines de banho de frente para o seu estabelecimento. Também tinha roupas para banhistas, serviços especiais para picnics, para sociedades esportivas e recreativas. Contava ainda com o serviço de transportes, conhecido na época como "auto-omnibus", que partia da estação dos bondes da sede da cidade, na llha de Santo Amaro.

Dessa forma, a região onde hoje se encontra o Balneário da Estância de Praia Grande, com a inauguração desse hotel (Hotel dos Alemães em 1928) e os diversos loteamentos que se sucederam a partir de então, começa a passar por um processo de valorização para o turismo, em especial o turismo de segunda residência. Em conseqüência disso, e do Marketing boca-a-boca, surge a necessidade de se oferecer uma infra-estrutura melhor, de modo a se obter retornos financeiros maiores. 
O Hotel dos Alemães, ao nosso ver, foi uma grande jogada estratégica de seus proprietários, pois localizava-se dentro de um dos empreendimentos imobiliários da região dos quais, estes loteadores detinham a propriedade (o loteamento do Jardim Guilhermina). A sua localização dentro desse loteamento facilitava a visita aos seus lotes pelos turistas que se hospedavam nesse hotel.

Ainda na década de 1920, precisamente em 1927, uma grande área de Praia Grande foi aterrada para o início da construção do Aero Club de Santos, inaugurado apenas em 1936. Este aeroclube ficou conhecido como Campo da Aviação e, a partir de então, o turismo foi crescendo na região.

O turismo, como as demais atividades sejam elas políticas, econômicas, culturais, de lazer e de outros tipos, provoca transformações no espaço, criando novos objetos para atender a essas novas demandas, desenhando ou até mesmo redesenhando a paisagem. Assim, o espaço em Praia Grande, por meio da paisagem, tem passado por constantes transformações desde o princípio do século vinte, alterando "a cara" desta estância balneária.

Portanto, no espaço turístico, esses agentes de transformação (políticos, econômicos, culturais e outros) interagem com o meio ambiente transformando sua dinâmica, seus processos e transformando a paisagem. A partir de sua invenção como lugar turístico, Praia Grande, passa a ter uma valorização social e econômica e, com isso, vem a exploração imobiliária por meio do turismo de segunda residência, trazendo um emaranhado de novos sujeitos antes inexistentes no cenário praiagrandense, além do seu crescimento urbano.

\section{3 - A segunda residência no crescimento urbano de Praia Grande}

Foi no início do século XX, como apontado por Siqueira (2002, p. 69), que se iniciou o turismo em Praia Grande. A partir daí, se deu a construção de vários estabelecimentos destinados a esse segmento de mercado; o turismo. A autora diz que, na época, eram poucos os atrativos e a infra-estrutura não era como as oferecidas nos dias atuais.

Sendo assim, tomando como base o que nos relatou a autora, para atender a esse fluxo de turistas que para lá se dirigiam em busca de lazer, e ainda com a construção desses estabelecimentos para atender ao turismo, como o Hotel dos 
Alemães, que marcou a história desta estância, o espaço começou a mudar e a passar por um processo de transformação. Contudo, um dos primeiros sinais da mudança do espaço, nesse ainda distrito de São Vicente, foi o loteamento da região na década de vinte, com a introdução das moradias de segunda residência.

Ao analisar este conceito de segunda residência, Boyer (2003, p. 56) enuncia:

"Todas as formas de residências secundárias são a maneira como a burguesia e também certas camadas intermediárias apropriam-se do prazer aristocrático do lazer na Natureza, no campo, afirmando seu sucesso social".

No entanto, hoje em dia, a nossa realidade em relação à aquisição de uma residência secundária, não é mais somente um sinal de "status" ou de afirmação do sucesso social das classes burguesas, como comenta o autor. O processo de industrialização, leis trabalhistas mais justas, melhoria das condições de vida da população do estado de São Paulo, fortalecimento da indústria automobilística na região da Grande São Paulo e interior, trazendo grandes investimentos de capitais estrangeiros, ajudaram e muito na conquista deste sonho, "a segunda residência". Além disso, com a ampliação do setor de serviços, inserção da mulher no mercado de trabalho, que passou a ajudar no orçamento doméstico, o fácil acesso aos diversos tipos de financiamento e tantas outras razões, também tornaram o sonho da residência secundária para as classes intermediárias, como mencionado pelo autor, em uma forma de afirmação de seu sucesso social.

Dessa forma, complementando os conceitos de segunda residência ou residências secundárias já enunciadas na introdução deste trabalho de pesquisa, no Censo Demográfico de 1991, identifica-se a segunda residência como sendo aquela de uso ocasional, um domicílio particular que serve de moradia, podendo ser um casa ou apartamento e a mesma é utilizada para descanso nos finais de semana, férias ou para outros fins. Mas será que a busca destes domicílios ocasionais se dão em qualquer lugar? O que buscam os consumidores deste tipo de imóvel? Para respondermos a essas perguntas, recorreremos a Ignarra (1999, p. 20) que relata o seguinte: 
"A procura por segunda residência se dá naquelas localidades onde 0 patrimônio natural e cultural diferem daqueles observados nas cidades de residência dos turistas. Assim, o consumidor deste tipo de imóvel procura paisagens naturais diferentes, climas diferenciados, grandes massas de águas representadas pelos rios, lagos, represas e, principalmente, o mar". (Ignarra, 1999, p. 20)

Desse modo,

"O fato é que o consumidor procura um ambiente que seja diferente de seu cotidiano e assim busca chácaras e sítios nas áreas rurais, e casas ou apartamentos o mais próximo possível da praia". (Ignarra, 1999, p. 20)

No entanto,

"A localização das residências secundárias tanto pode ser rural quanto urbana”.(Ignarra, 1999, p. 20)

Assim, como foi bem destacado pelo pesquisador, os turistas buscam algo diferente do que é praticado no seu dia a dia, ou seja, buscam lugares em que tanto a cultura quanto a natureza diferem de seus locais de residência.

No caso de Praia Grande, por estar próxima ao mar e de grandes centros urbanos, a introdução da segunda residência tem sido uma forte influência na produção do espaço e na transformação dos ecossistemas desta estância balneária do início do século passado para cá.

Casella (2004, p. 106), ao analisar o caso do balneário de Bertioga, no estado de São Paulo, afirma que:

"Este fenômeno, amplamente difundido no estado de São Paulo [segunda residência], tem forte influência na produção e/ou reorganização dos espaços eleitos para abrigá-los (...)".

Desse modo, para ela, o turismo litorâneo: 
“(...) é o principal segmento, não apenas em São Paulo, mas em todos os estados brasileiros com litoral, e acabam favorecendo o surgimento das chamadas segundas residências, fortalecendo uma característica do litoral brasileiro: forte ocupação e transformação de ecossistemas litorâneos, naturais e frágeis, em áreas urbanizadas" (Casella, 2004, p. 106).

Nesse sentido, é neste contexto apontado pela autora, que o fenômeno do turismo de segunda residência acaba levando Praia Grande a transformações de seus ecossistemas naturais, influenciando a produção do espaço e transformando este espaço em áreas urbanizadas por meio de seus loteamentos e construções de segundas residências a partir do princípio do século $X X$.

Assim, com esses loteamentos, o turismo de segunda residência se instaura em Praia Grande e o espaço passa a ser uma mercadoria e com interesses econômicos, em que o turismo torna-se uma atividade consumidora de espaço.

Ao se referir ao consumo do espaço, $\operatorname{Cruz}(1999$, p. 3) aponta que:

\begin{abstract}
"o consumo do espaço pelo turismo é intermediado por inúmeras formas de consumo, entre as quais pode-se listar os meios de transportes, de hospedagem e de restauração, o setor de agenciamento da atividade, os serviços bancários, o comércio de bens de consumo de modo geral etc. Quando se consome espaço, em turismo, está-se consumindo um conjunto, indissociável, de bens e serviços que compõem o 'fazer turístico".
\end{abstract}

Portanto, para que um lugar possa "fazer-se turístico", ele vai precisar de toda uma infra-estrutura para atender ao turismo e a organização deste espaço tem que refletir esse conjunto indissociável de bens e serviços para o acolhimento dessa clientela, os turistas. Assim, a preocupação com o atendimento adequado dessas inúmeras formas de consumo, não pode ser deixada para segundo plano; quanto mais sofisticados os turistas, mais sofisticados tem que ser esse conjunto de bens e serviços oferecidos. Daí, a importância dos agentes privados trabalharem em associação com os agentes públicos no suprimento destas necessidades a serem supridas pelo turismo local. Dessa forma, ao materializar as expectativas dos turistas, criando a infra-estrutura necessária ao atendimento 
desta atividade, o espaço, produzido como mercadoria, vai se valorizando e a utilização desse espaço de lazer passa a implicar em uma atividade econômica.

Nesse sentido, Sanchez (1991, p. 217) enuncia que:

\begin{abstract}
"A utilização do espaço de ócio implica uma atividade econômica que o transforma em mercadoria capaz de ser usada. Desde esta perspectiva o turismo é visto como um setor de produção econômica (...) Neste sentido adquire singular importância a demanda de espaço de ócio e, entre ela, de forma significativa, de espaço de ócio litoral." ${ }^{35}$
\end{abstract}

Nesse sentido, na visão de Sanchez (1991), a utilização do espaço para o lazer implica em uma atividade econômica que demanda por uma série de produtos e serviços que se estabelece como um setor de produção econômica. Contudo, Rodrigues (1999, p. 56) nos diz que o turismo é uma mercadoria cuja marca é o consumo de espaço. Sendo assim, esse espaço, por sua vez, é transformado em infra-estrutura passível de permitir a acomodação de pessoas, a sua circulação, e também, a de mercadorias e de serviços. Nesta perspectiva, o turismo se coloca, como elucidado por Sanchez (1991, p.217), como um setor de produção econômica que demanda por espaço de lazer. Dessa forma, o espaço passa por uma valorização de caráter econômico.

Sanchez (1991, p. 218) fala de um outro tipo de valorização, a valorização social a qual deve ser acompanhada da possibilidade de uso deste espaço, e quando esta ocorre, acaba levando a transformações no espaço. Ainda na mesma página, ele continua:

${ }^{35} \mathrm{O}$ texto original, na língua espanhola, diz:

"La utilización del espacio de ocio implica una actividad económica que lo transforma en mercancia capaz de ser usada. Desde esta perspectiva, el turismo se plantea como un sector de producción económica (...) En este sentido adquire singular importancia la demanda de espacio de ocio y, entre ella, de forma significativa, de espacio de ocio litoral". 
"A valorização social destes espaços, deve ser acompanhada da possibilidade de serem usados. Quando passa a ser massivo, será o momento no qual as transformações do espaço também serão massivas, mediante a uma atuação intensiva sobre o território". ${ }^{36}$

Assim, conforme comentou o autor, com essa valorização social, o espaço começa a ser transformado para atender as demandas do turismo massivo ${ }^{37}$, ou seja, novos objetos técnicos são criados de modo a favorecer o turismo na Estância Balneária de Praia Grande.

Magalhães (1965, p. 65) nos diz que aproximadamente entre o final da década de 1920 e início da década de 1930, a região onde hoje está a Praia Grande, não era habitada, senão por pequenos núcleos de praianos que se dedicavam a pequenas culturas e a pesca. Ele continua:

\begin{abstract}
"A partir da década de 1930, o número de veranistas, que antes se podiam contar nos dedos, aumentou progressivamente e principalmente após a última guerra, eliminando de vez o caiçara da paisagem. Tal se deve mais a intensa propaganda desenvolvida pelas campanhas loteadoras e as facilidades oferecidas na compra de terrenos do que as melhorias efetuadas, como fortemente de energia elétrica e abertura de vias de acesso".
\end{abstract}

Dessa forma, ainda no início da década de trinta, a infra-estrutura da região de Praia grande era muito precária, mas era compensada com a beleza da paisagem natural e agradável de seus $22,5 \mathrm{~km}$ com a função balneária quase inexplorada, a tranqüilidade, o clima quente e a proximidade com o mar. Todas essas características próprias criaram diferenciais únicos em relação às demais regiões próximas à Praia Grande, como, por exemplo, em relação à cidade de Santos, que já estava urbanizada e com função balneária bem explorada nesta época. Assim, Seabra (1979, p. 14-15) nos relata que "ao se iniciar a década de

36 Conforme texto original em espanhol:

"A la valoración social de estos espacios, debe acompanarle la posibilidad de ser usados. Cuando pasa a ser masivo, será el momento en el cual las transformaciones del espacio también serán masivas, mediante una actuación intensiva sobre el territorio".

${ }^{37}$ Cruz (2003, p. 6) define turismo de massa ou massivo como sendo "uma modalidade de turismo que mobiliza grandes contingentes". 
20, a função balneária da cidade [Santos] era altamente explorada. (...) As ruas sempre cheias de gente, as praias concorridíssimas, os clubes de regatas com suas sedes sempre repletas, em toda parte enfim, a cidade entoava de vida". Diante do que foi exposto por Seabra (1979, p. 14-15), Praia Grande por estar tão próxima a cidade de Santos e de outras regiões, como as regiões do planalto paulista, passa ser um atrativo, devido a ter sua função balneária quase inexplorada em relação à sua sede em São Vicente e a cidade de Santos.

Podemos então dizer que somavam-se a estes diferenciais, em relação aos seus vizinhos, a facilidade de acesso que começara a desfrutar e a exposição que passava a ter devido à quantidade de turistas que para lá se dirigiam em busca de suas belas praias. O Hotel dos Alemães teve papel importante nos primeiros momentos da introdução da segunda residência, pois o mesmo, além de atender a demanda de veranistas que para lá se dirigiam, também ajudou a despertar o interesse em se adquirir um lote para a segunda residência naquele distrito de São Vicente, uma vez que esse hotel localizava-se dentro de um dos primeiros loteamentos da época, o do Jardim Guilhermina.

Dentro desse contexto, no que concerne à freqüência das visitas às suas praias, pouco tempo depois da inauguração da Ponte Pênsil, em 1914, o número de carros alugados que levavam turistas para a região de Praia Grande advindos de Santos e São Vicente aumentava. É por volta de meados do final da década de 1920 que começa a demanda por terras nessa região, mas os loteamentos começaram ainda no início de 1920. Cabe-se ressaltar que, Heitor Sanches estava, segundo matéria do jornal A Tribuna (A TRIBUNA, Santos, s.d., s.p.), entre os primeiros loteadores de Praia Grande:

“(...) entre aqueles que desde de cedo, acreditaram em Praia Grande, quando isso era considerado uma loucura. Já possuía terras, quando no início da década de 20, indicou aos Irmãos Guinle, maiores acionistas da Cia Docas de Santos, a compra da gleba que originaria o Jardim Guilhermina (nome da progenitora dos irmãos Guinle). A gleba custou 250 contos de reis, uma fortuna para época e o loteamento foi iniciado em 22. Dona Circe, filha de Heitor Sanches, guarda consigo preciosa documentação, que comprova a participação de seu pai e de seu marido, Oswaldo Toschi, no desenvolvimento de Praia Grande. Entre os documentos, há a relação de compradores de terrenos da Cia Territorial Jardim Guilhermina, cujo gerente era Sanches até 29". 
Assim, a Cia Territorial Jardim Guilhermina, com grandes investimentos no início da década de vinte, marca a sua presença na história desse distrito de São Vicente, como a primeira empresa no ramo da exploração imobiliária para atender ao turismo de segunda residência nessa estância balneária e, dessa forma, adquire grandes glebas de terras dos antigos pescadores e moradores da região. É a partir dessa época que surge o turismo de segunda residência em Praia Grande.

Vale destacar que, de acordo com Dona Circe Sanchez Toschi, antiga moradora da região, e filha de um dos proprietários (Heitor Sanchez) do Jardim Guilhermina (ver foto 17), e de outros empreendimentos em Praia Grande, "em 1928, [no Jardim Guilhermina] já haviam sido construídas cinco moradias [destinadas a segunda residência] para serem vendidas ao preço de dez contos de reis cada uma e a longo prazo". Nesse sentido, as pessoas interessadas em investir em Praia Grande também tinham a opção de comprar seus lotes e mandar construir sua segunda residência ou como chamadas na época, "vivendas de fim de semana e férias". 38

\footnotetext{
${ }^{38}$ Nas iconografias do Jardim Mathilde, Balneário Florida e outros que serão mostradas mais adiante, este termo "vivendas de fim de semana e férias" é muito usado nas propagandas destes primeiros loteamentos da época. Esta expressão está para a época, como a de segunda residência ou de uso ocasional, está para os dias atuais.
} 
Foto 17 - Foto aérea do loteamento do Jardim Guilhermina em 1928

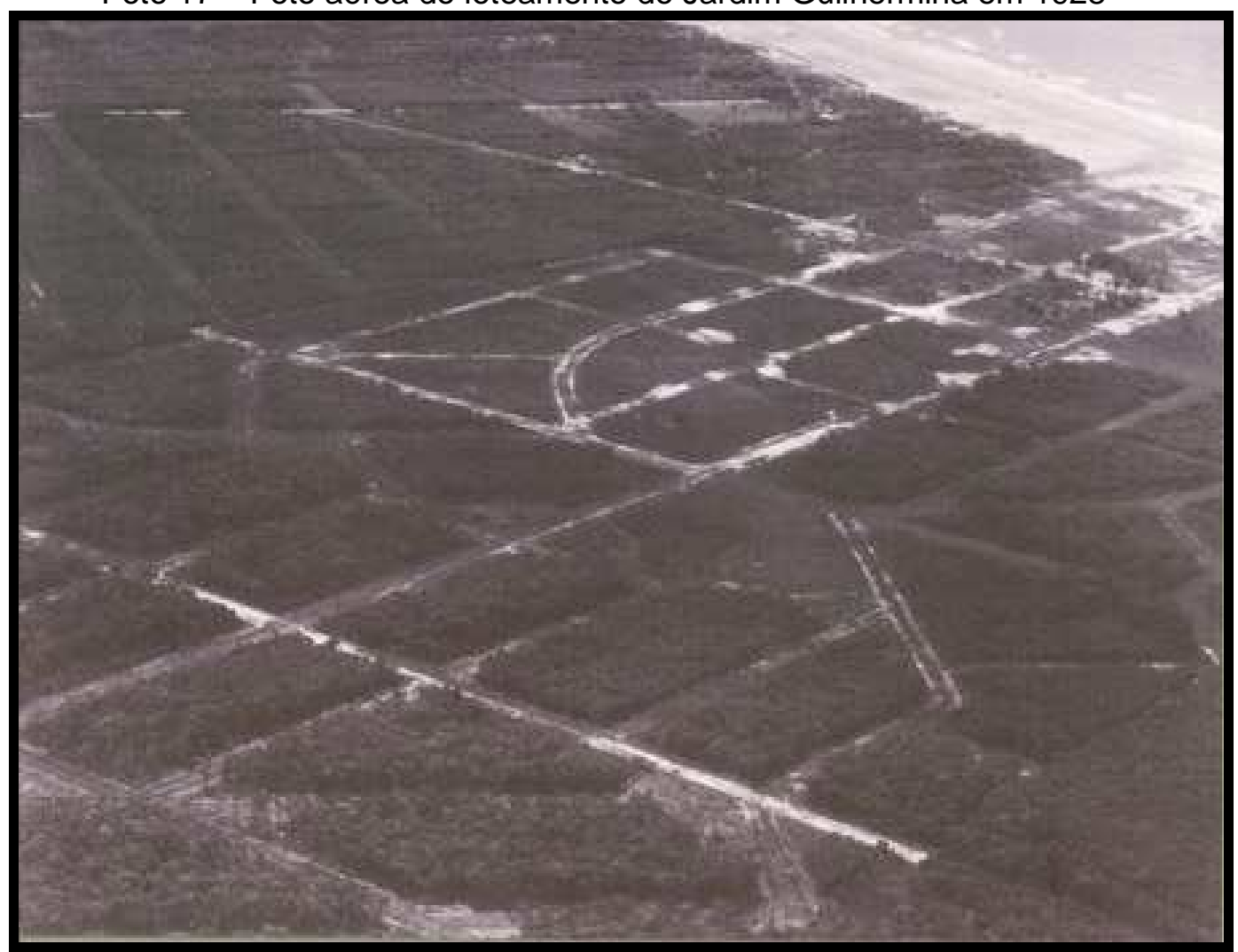

Fonte: Acervo particular de Circe Sanchez Toschi - Autor desconhecido

Entre os primeiros grandes loteamentos destinados às segundas residências que se tem registro em Praia Grande está o do Jardim Guilhermina, no final da década de 1920. Podemos perceber pela foto acima, as divisões dos lotes e seus arruamentos. Nesta época, o Jardim Guilhermina ainda tinha boa parte da Mata Atlântica a mostra, porém foi sendo retirada aos poucos e sua lenha vendida para as cidades de Santos e São Vicente. Era dentro desse loteamento que estava localizada a primeira Pensão e o primeiro Restaurante da região, que mais tarde, seria mais conhecido como Hotel dos Alemães.

Portanto, esse loteamento, no final da década de 1920 e início da de 1930, já contava com água encanada por meio de poço artesiano, luz elétrica, empório e materiais para construção que vinha de uma olaria (ver foto 18) da própria Praia Grande. Era muito comum encontrar panfletos falando deste empreendimento (ver figura 07). 
Foto 18 - Olaria do Jardim Guilhermina

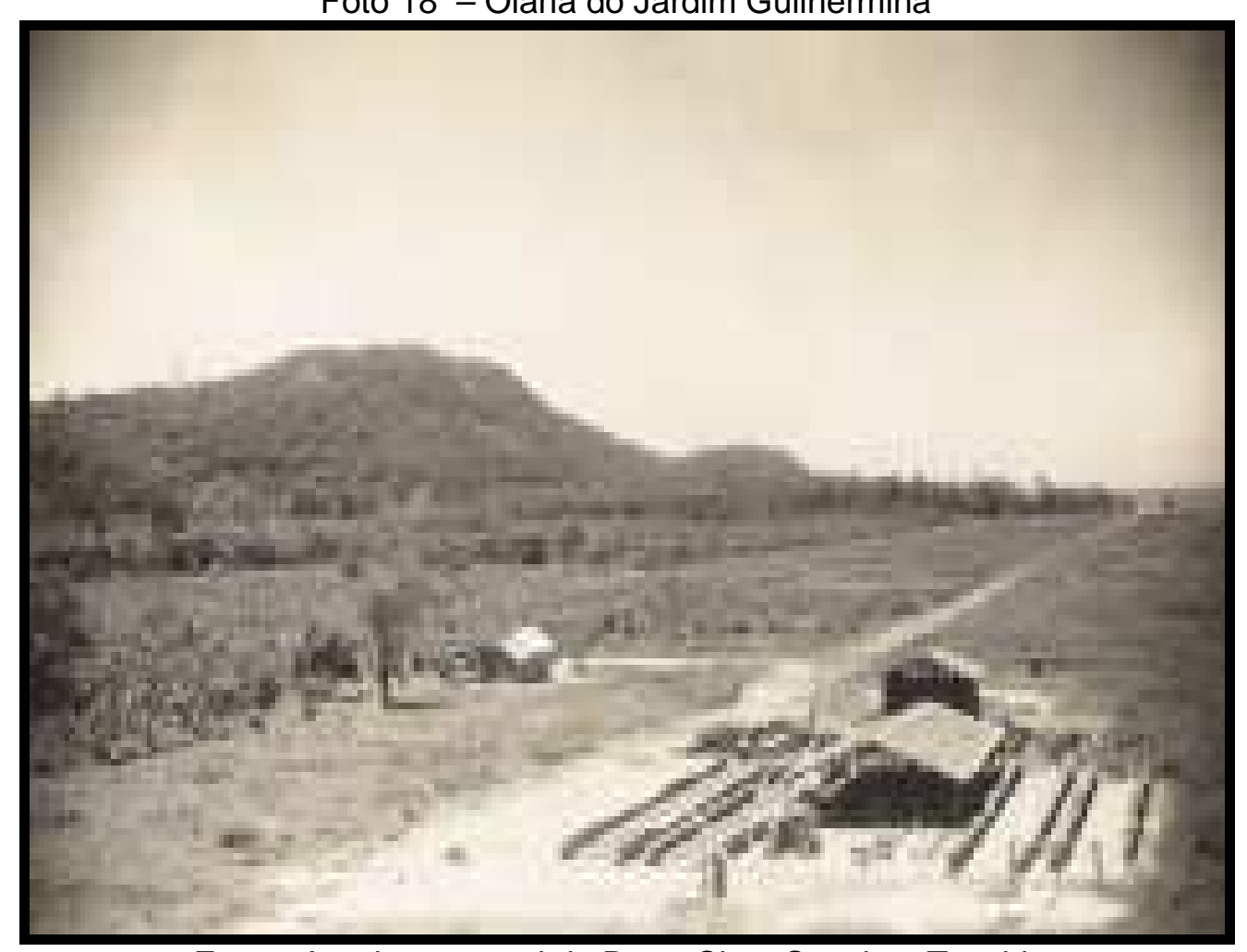

Fonte: Arquivo pessoal de Dona Circe Sanchez Toschi

Autor Desconhecido

Essa olaria durante muitos anos forneceu os tijolos para uma boa quantidade de loteamentos da região de Praia Grande.

Desse modo, o uso de ferramentas de Marketing, como folhetos que promoviam seus empreendimentos imobiliários já eram bem utilizados pela Companhia Territorial Jardim Guilhermina (ver figura 08), na segunda metade da década de 1920. Esse folheto, distribuído na região da Baixada Santista e São Paulo, trazia consigo um mapa (na escala 1:100.000) e informações importantes sobre a infra-estrutura oferecida, bem como, as condições de pagamento. 
Figura 07 - Propaganda do Jardim Guilhermina

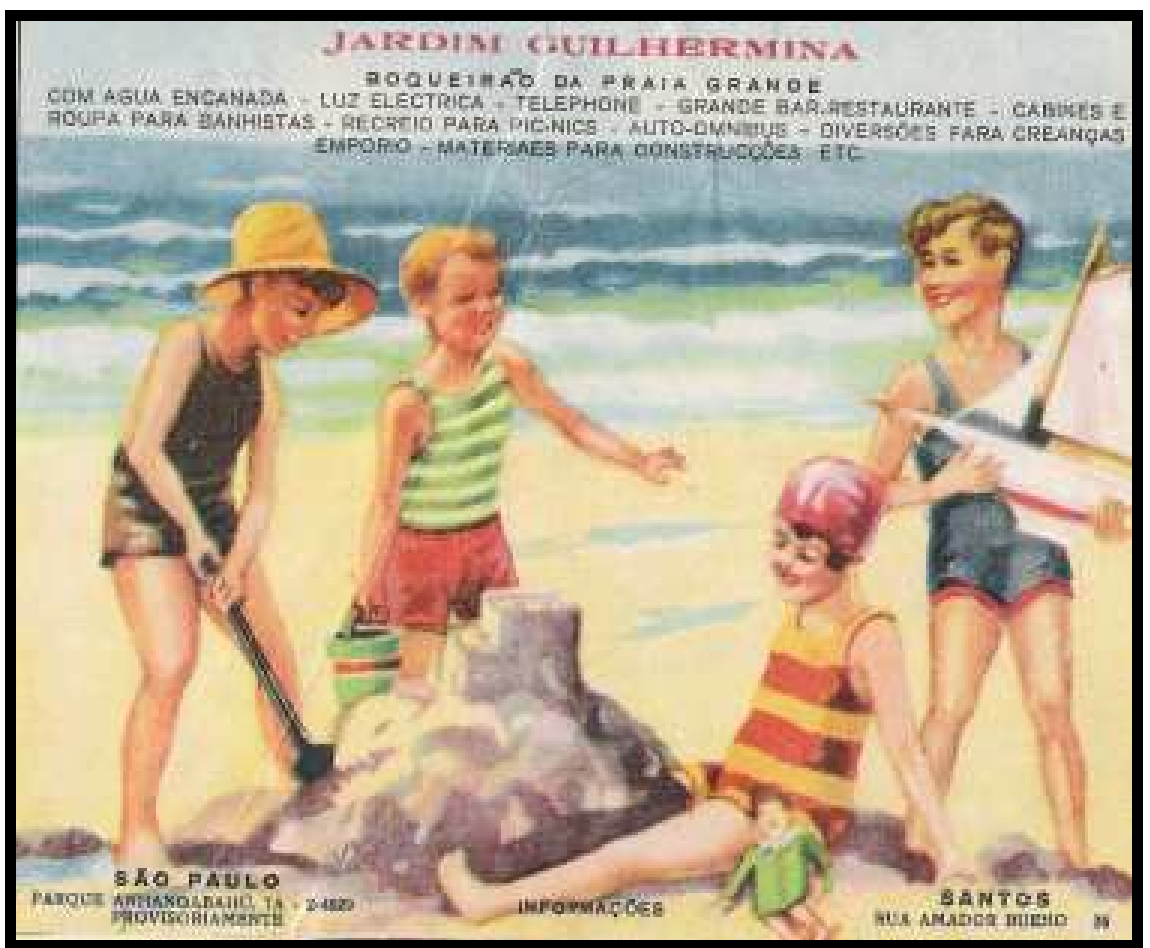

Fonte: Arquivo pessoal de Dona Circe Sanchez Toschi

Como nos mostra a iconografia acima, a Cia Territorial Jardim Guilhermina tinha escritório em São Paulo capital e em Santos.

No final da segunda metade da década de 1920, já existiam, no Distrito de Praia Grande, o qual na época ainda era um distrito de São Vicente, 14 empreendimentos imobiliários destinados à segunda residência, chamados de "vilas", por seus loteadores. Dois na região que denominavam "Itaipu Boqueirão", compreendiam o Parque Paris, a Vila Mathilde e doze outros empreendimentos na região denominada "Boqueirão - Mongaguá", que compreendiam: O Jardim Guilhermina, Vila Sarita, Vila Oceânica, Vila Tupy, Oceânica Amábile, Vila Santa Thereza, Vila Beiramar, Parque Copacabana, Nova Ostende, Vilas Balneária I e II e Vila Bopeva, com suas respectivas localizações no mapa por eles fornecido (ver figura 08).

No entanto, em relação ao crescimento de loteamentos e exploração imobiliária da região, Praia Grande pedia por mais providências, no que tange à infra-estrutura para essa população que estava investindo em lotes nesse distrito de São Vicente. Nesse sentido, novos arruamentos e infra-estrutura básica se 
faziam necessários com o crescimento urbano. Assim, influenciado pelas lindas e extensas praias da região, o processo de ocupação do espaço e de urbanização vai ocorrendo aos poucos na região praiagrandense, enquanto a exploração imobiliária neste balneário cresce explorando as segundas residências como forma de ganhos fáceis.

Cabe-se lembrar que um momento de destaque junto com o da exploração imobiliária que marcou a ocupação na região da orla marítima de Praia Grande foi a construção do Aeroclube da cidade, em 1936, empreendimento que foi mais um atrativo para trazer turistas para a região. Esse Aeroclube recebeu muitas visitas ilustres e vale lembrar que, no novo Plano Diretor de Praia Grande, está escrito que um desses visitantes ilustres foi o ex-presidente Getúlio Vargas, além de respeitados aviadores nacionais e internacionais (BRASIL, São Paulo. Lei Complementar nำ 473, de 27 de dezembro de 2006).

Nas décadas seguintes, intensifica-se a utilização e aprimoramento do sistema viário e de transportes coletivos em substituição ao lombo de mulas, carroças e canoas, que foram por muito tempo, os únicos meios de transporte para o trajeto entre São Vicente e Itanhaém. A partir de então, com a melhoria nos meios de transportes, a Praia Grande do princípio do século passa de uma área de pequenos sitiantes para um lugar de empreendimentos imobiliários com loteamentos e comércio para atender à demanda cada vez mais crescente de turistas que se dirigem à sua região.

Na década de 1940, temos um outro grande loteamento em Praia Grande, o do Balneário Flórida (ver foto 19). Heitor Sanchez, nessa época, após ter ficado ausente de Praia Grande por uma década, volta ao ramo da exploração imobiliária, desta vez, com a Cia Territorial Praia Grande S.A, participando, inclusive desse empreendimento.

Vale ressaltar que, nessa época, de acordo com Ferrara (1999, p. 46), a metrópole de São Paulo, de 1938 a 1945, "já se apresentava como o maior centro industrial da América Latina". Portanto, já era um pólo dominante e que influenciava no crescimento das regiões litorâneas da atual Baixada Santista. 
Figura 08 - Empreendimentos imobiliários de Praia Grande na segunda metade da década de 1920 - Jardim Guilhermina Figura 8 - Empreendimentos imobiliários de Praia Grande na segunda metade da década de 1920 - Jardim Guilhermina

○

s terrenos da Companhia Territorial "JARDIM GUILHERMINA" - Boqueirão da Praia Grande - com agua, luz $\theta$ telephone sã - os mais proximos de Santos como está demonstrando claramente nesta planta. Distam apenas 300 metros do Boqueiráo.

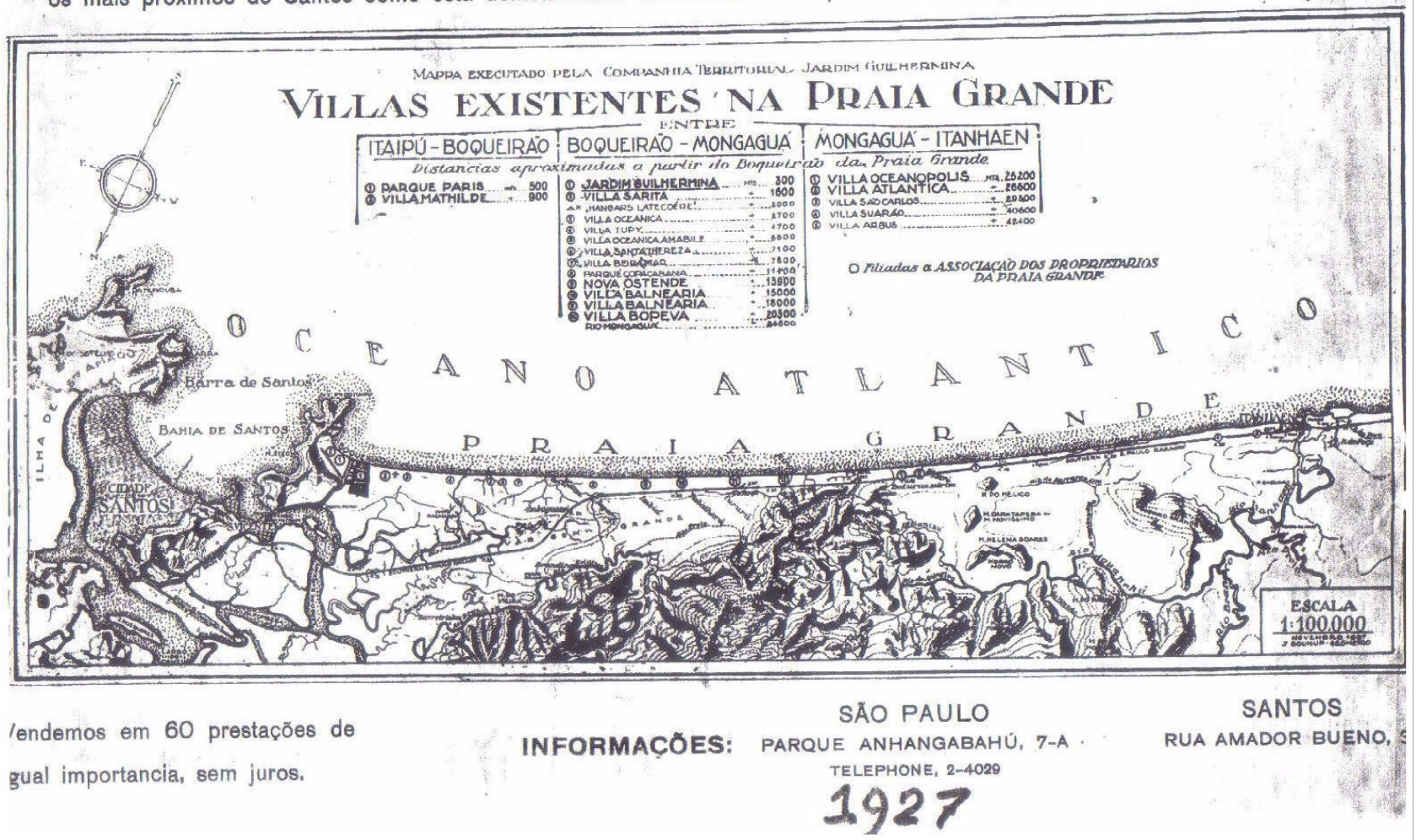

Fonte: Acervo particular de Circe Sanchez Toschi - Autor desconhecido

Fonte: Acervo particular de Circe Sanches Toshi - Autor desconhecido 
No entanto, conforme essa fonte iconográfica (veja figura 09), no final da década de 1940, o único acesso a essa região localizada no extremo oeste do distrito de Praia Grande era por trem, pela Estrada de Ferro Sorocabana, que tinha como ponto de partida, a cidade de Mairinque, utilizava-se o ramal SantosJuquiá, que tinha uma parada dentro da propriedade do loteamento do Jardim Flórida, conhecida como "Parada Dias". Assim, a ligação de São Paulo a Santos pela Estrada de Ferro Sorocabana estava, na época desta campanha promocional do loteamento, a um ano de sua conclusão.

Foto 19 - Foto aérea do loteamento do Jardim Flórida em 1946.

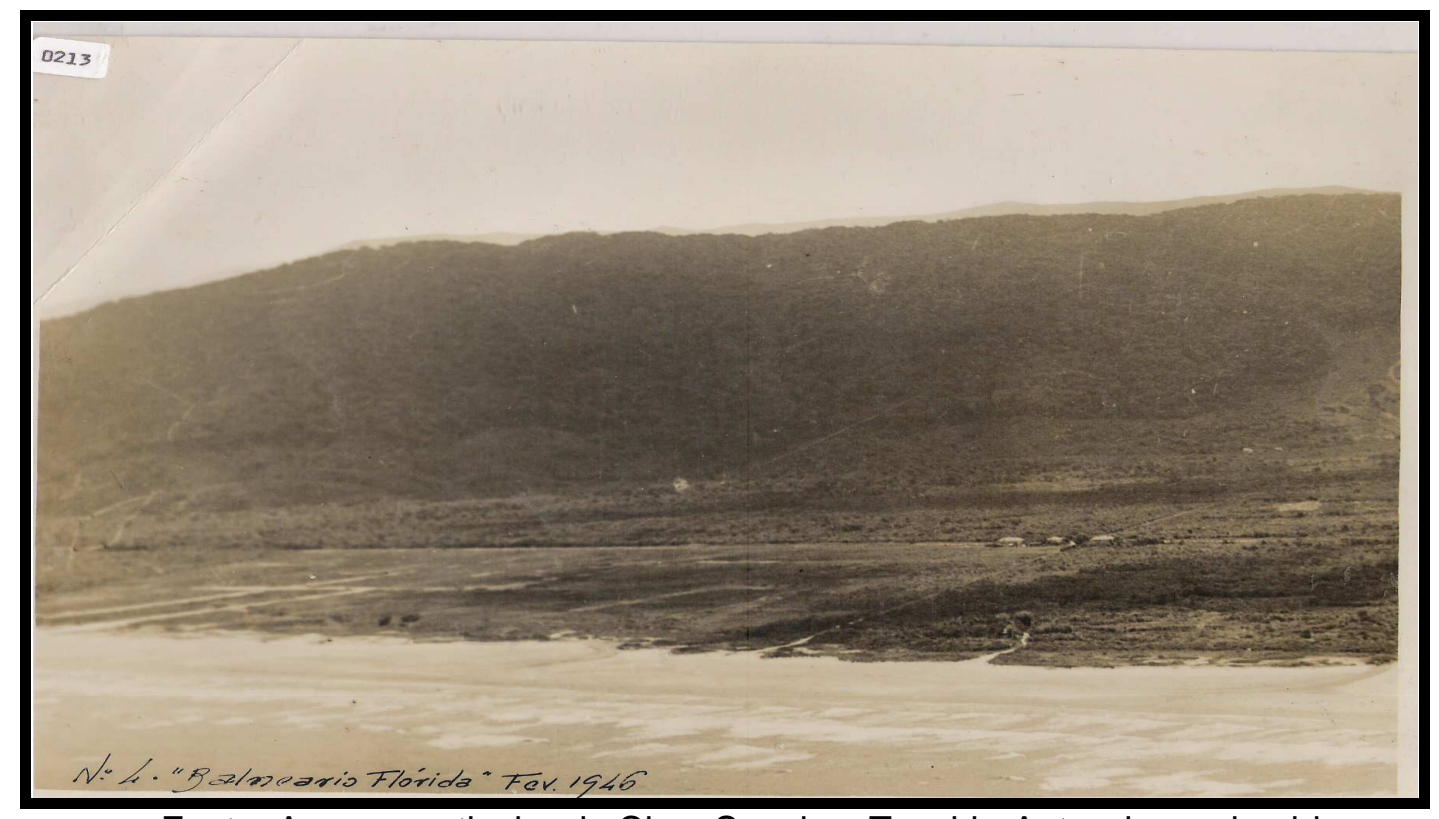

Fonte: Acervo particular de Circe Sanchez Toschi - Autor desconhecido

Na foto acima, tirada em fevereiro de 1946, vemos no canto inferior esquerdo, o principio de arruamentos para a efetiva divisão em lotes, com grande parte da antiga Mata Atlântica já removida. Já no canto inferior direito, de posse da foto original e com o auxílio de uma lupa, identificamos quatro moradias.

A outra forma de acesso ao loteamento era pelas areias da praia, cuja distância não chegava a 18 quilômetros do Boqueirão. Vale ressaltar que, em seu apelo promocional para despertar o interesse pela compra de lotes na região, já se falava da existência de um projeto do governo, ligando o Balneário Flórida ao Boqueirão por meio de uma estrada de rodagem. 
Figura 09 - Propaganda do Balneário Flórida

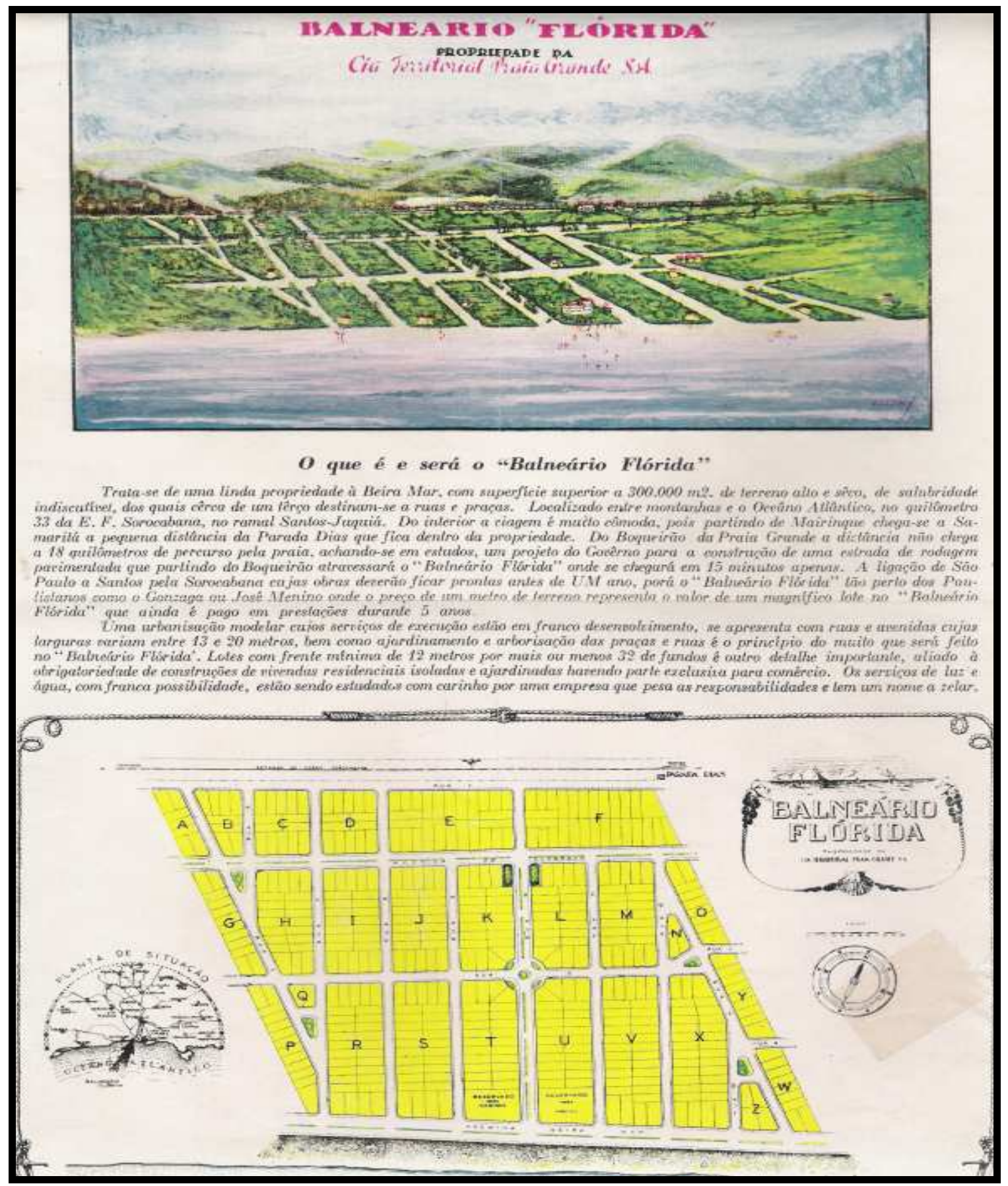

Fonte: Arquivo pessoal de Dona Circe Sanchez Toschi

$\mathrm{Na}$ iconografia da página anterior, em seu projeto paisagístico, já se previa que cerca de um terço da propriedade seria destinado a ruas e praças, e ainda, no projeto constava uma futura avenida beira-mar que já estava em estudo, mas ainda sem previsão de data, a instalação de energia elétrica e água encanada. 
Assim, com esses novos loteamentos mais pessoas se instam no distrito de São Vicente, promovendo com isto, o crescimento espacial das vilas e fazendo com que o tecido urbano avançasse sobre novos espaços.

\section{4- O Tecido urbano na primeira metade do século passado}

Em nossos levantamentos, descobrimos documentos antigos como o Edital № 344 (BRASIL, São Vicente. Edital no 344, de 28 de abril de 1944.) ${ }^{39}$ da Prefeitura Municipal de São Vicente, em que se menciona a existência, em 1944, de 19 vilas na região de Praia Grande, conforme nos diz este edital:

"De acordo com o Edital № 344 da Prefeitura Municipal de São Vicente, o prefeito municipal de São Vicente, usando de suas atribuições, tendo em vista o preceito da Lei 194 de 10/11/1926, que regula o arruamento neste município, concede o prazo de 45 dias contados da data deste edital, para que proprietários das vilas abaixo relacionadas colocarem marco de pedra, de acordo com o tipo adotado pela prefeitura, nos vértices de respectivas quadras, afim de facilitar a ligação das mesmas na planta cadastral da cidade, cuja confecção se acha em vias de conclusão.

Findo o prazo acima citado, esta prefeitura não atendera aos requerimentos de construção, ligação de água, etc. relativos aos terrenos de tais vilas, cujos proprietários deixarem de atender a esta intimação.

Relação das vilas situadas em Praia Grande: Alzira, Augusta, Balneária, Beira Mar, Camargo, Condomínio Boqueirão, Elida, Empresa Praia Grande de Terrenos, Itaipus, Itália, Jardim Guilhermina, Matilde, Jardim Nomar, Nova Ostende, Oceânica, Oceânica Amábile, Parque Jahu, Santista e Tupininquins".

Assim, desde 1944, quando ainda existiam vilas e pedia-se pelos seus arruamentos, muitas foram às mudanças no tecido urbano dessa estância balneária.

Complementando, a matéria do jornal A Tribuna (A TRIBUNA, Santos, s.d., s.p.) registra:

${ }^{39}$ A Prefeitura de São Vicente, usando de suas atribuições de jurisprudência sobre o Distrito de Praia Grande, faz uma publicação em nome do seu prefeito municipal, Sr. Polidoro O. Bittencourt, citando a Lei 194 de 10/11/1926 o qual regula o arruamento das cidades e municípios e concede um prazo de 45 dias para que os proprietários das vilas coloquem marco de pedra para o arruamento de tais vilas. 
"Com carroças e burros, o Jardim Mathilde começou a ser loteado em 1940 (...) Dona Circe diz que Heitor Sanches sonhava por um loteamento ideal, inspirado nos que vira em Washington (conhecia 52 países) com casas amplas, jardins espaçosos e muretas baixas. E assim fez no Mathilde e no Flórida, onde chegava a organizar concursos dos mais belos jardins. Até hoje se mantém restrições no Código de Obras para evitar a descaracterização desses dois bairros. Mas os muros baixos, pela violência dos tempos modernos, tiveram de ser substituídos por verdadeiras muralhas ou por grades".

Dessa forma, percebemos que o projeto destes dois loteamentos, o Flórida e o de Vila Mathilde, previa casas amplas, com jardins espaçosos e com muretas baixas, ambos inspirados no que seu loteador vira nos Estados Unidos, especificamente no estado de Washington. A planta foi idealizada pelo seu proprietário (ver figura 10 e 11), que (após o seu afastamento pelo período de 10 anos do balneário de Praia Grande) utilizou, para esse novo empreendimento, a Companhia Territorial Praia Grande S.A. Todavia, essa companhia tinha como presidente, o Sr. Nestor Ferreira da Rocha, como gerente, o próprio Heitor Sanchez, secretário, Dr. José Ferreira Rocha Fo e o conselho fiscal era composto pelos senhores Herculano de Almeida Pires, Oddone F. Aleide e Orivaldo Lima Cardoso com sede provisória em São Paulo.

No entanto, ainda nessa década, ocorre o aparecimento de uma nova forma urbana que marcaria a história da ocupação e urbanização em Praia Grande e que substituiria as casas de veraneio ou "vivendas de fim de semana ou férias". Essa nova forma urbana seria o surgimento dos prédios, uma nova opção de moradias verticalizadas, abrigando várias moradias em um só terreno e com isso caracterizando uma nova forma de uso e ocupação do solo neste distrito de São Vicente. 
Figura 10 - Propaganda do Jardim Mathilde (frente)

\section{Q Jardin Malilide}

Situado no más lindo e tranquilo recanto do Boqueiräo da Pruia Grande abrizado pelos, magestosos morros Xixová e Itaipú apresenta-se com as seguintes carateristicas e methoramentos em franco desenvolvimento.

Praia limpa, mar aberto e abroluta seguranna para banhistas * Lugar preferido para pescarrias * Arruamento modelar * Bairro exclusivamente residencial näo sendo pernitida a construçâo de Edifícios em Condominio * Obrigatoriedade de jardim $\mathrm{na}$ frente das vivendas coma afastamentos lateraes $* 5$ lotes para casss comerciaes * Lotes com frentes mínimas de 12 metros e fundos de 28 metros $*$ Caprichad decoraçäo nos jardins e arborisaģăo das ruas $\star$ Colocagáa de guvis de granito e sargetas de paralelepipedos com as juntas betuminadas * Conservą̧äo aprimorada das ruas e jardins e turna de zeladores para as vivendas $\star$ Area reservada para construggäo de Igreja na Praça Claudino L Luz elérica e linha de força $\star$ Telefone * Locomoģa fácil e diréta näo dependendo de barcas ou ferriboats $*$ Estrada asfaltada atravessando a Ar.J. Tavora * Linha de onibus com partidas de Säo Vicense de ora em ora e que passann na frente da propriedade e finalmente para maior conforto dos proppietários será oportunamente construido junto ao Xisoví um

\section{CLUBE DE CAMPO}

que ocupará uma área de cerca de 23.000.00 metros quadrados e terá as seguintes carateristicasiSéde tipo Campestre com amplo Saläo para Danngas, Bar, Bilhares, Snooguers, Ping.Pong, etc.

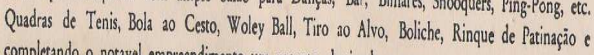
completando o notavel empreendimento um recanto destinado a um

RECREIO PARA CREANÇAS com Balangos, Gangorara, the.

Dispomos de algumas áreas destinadas a

CASAS DE DESCANÇO COM PARQUE ANEXO

Olaria e pedereira propprias, em franca produção, facilitarão as construycoecs.

\section{AVENIDA BEIRA MAR}

A Préétura de Såo Vicente ja claborou o projecto dessa Avenida que terá a lareura de 24 metros e será brevemente construida no trecho entre o Boqueirào e 0 Itaipú

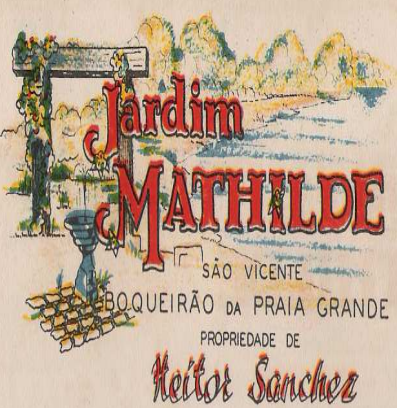

Um recanto ideal e encantador a BEIRA MAR, junto a montanhas, para a construção de vivendas e Férias

- Vendedores Exclusivos -

Companhia Territorial Praia Grande S/A.

\section{CAPITAL REALISADO Cr.S Mavomo \\ - Aumento auterisado 1000,00000}

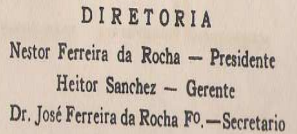

CONSELHO FISCAL

Herculano de Almeida Pires Oddone r. Alcide Orivaldo Lima Cardoso

-

Inlormaçöes na sóde provisoria

R. José Bonilácio, 110 - 2., s/loja - sola 3 - Tolefono 3.5835 - Säo Paulo

Fonte: Acervo particular de Circe Sanchez Toshi

O loteamento de Vila Mathilde previa área para construção de Igreja e cinco estabelecimentos comerciais, área de recreação para crianças, clube de campo e já com estrada asfaltada com acesso pela Av. Joaquim Távora (antiga Estrada Variante e atual Avenida Marechal Mallet). Tal panfleto menciona o projeto de uma futura avenida Beira Mar. 
Figura 11 - Propaganda do Jardim Mathilde (verso)

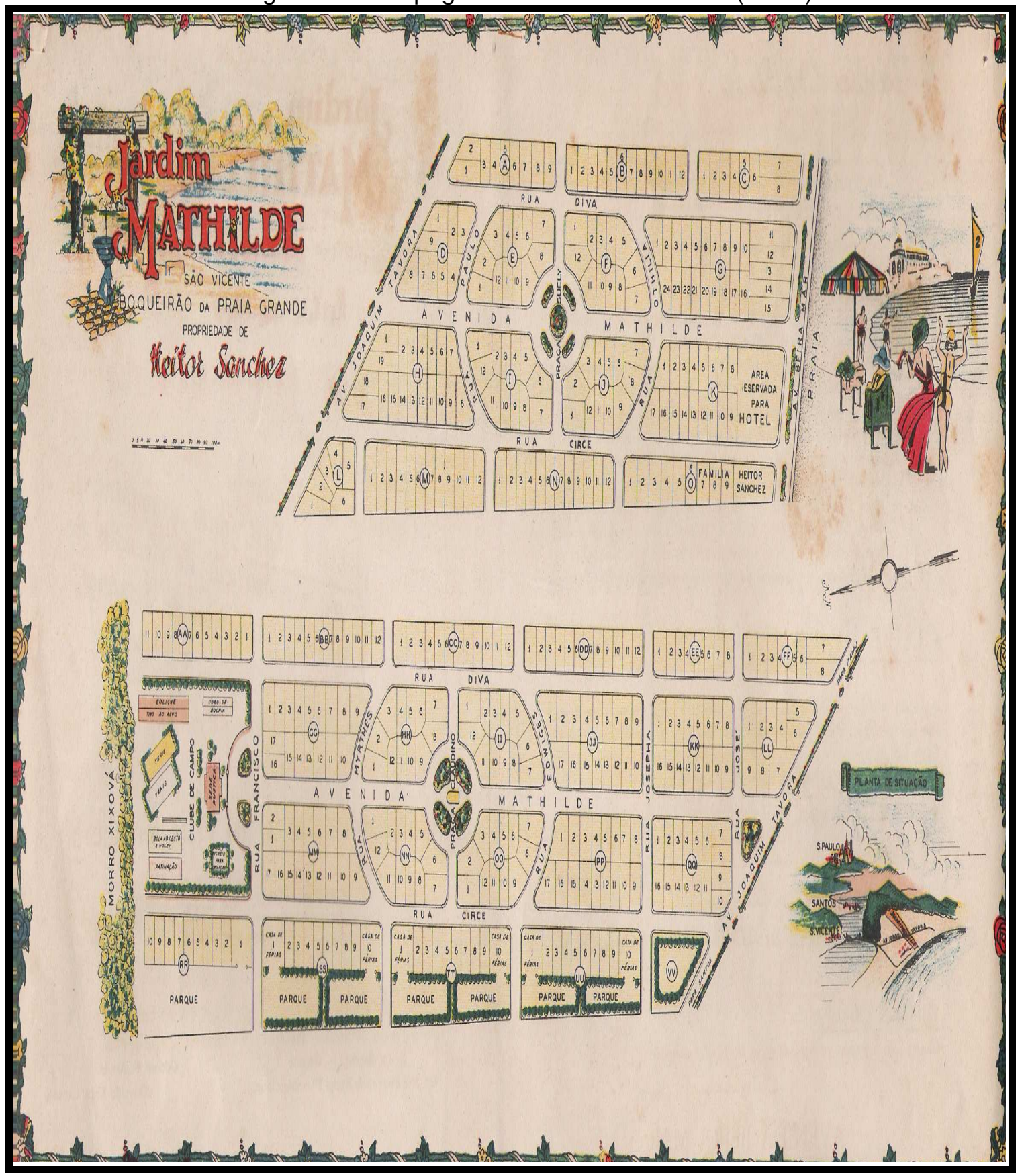

Fonte: Acervo particular de Circe Sanchez Toshi - Autor desconhecido

Esse empreendimento de Vila Mathilde tinha em sua concepção a proibição da construção de edifícios em condomínios, previa arruamentos modelares, dava diretrizes que deveriam ser seguidas à risca pelos futuros proprietários dos lotes na construção de suas segundas residências. Nesse panfleto, as segundas residências ou de uso ocasional são chamadas de "vivendas de fim de semana e férias". 
Contudo, em relação a essa nova forma de construir, Lee $(1998$, p. 78$)$ nos aponta:

\begin{abstract}
"Percebemos então que dentro desta nova maneira de construir, a valorização imobiliária também se modificou uma vez que dentro deste contexto, a indústria da construção redefiniu a forma de apropriação do espaço. Os terrenos passaram a ser utilizados e comercializados no seu potencial máximo, abrigando várias unidades habitacionais num só terreno, através da construção em altura".
\end{abstract}

Portanto, essa nova maneira de construir, a verticalização, além de introduzir uma nova forma urbana à paisagem de Praia Grande, também causaria um incremento na população nesse distrito de São Vicente.

\title{
2.5 - A nova forma urbana e o incremento da população
}

A nova forma urbana foi introduzida nessa estância antes da segunda metade do século passado e com as grandes transformações e melhorias que foram introduzidas nesse balneário, também vieram um grande contingente de pessoas, atraídas por suas belezas naturais, melhor qualidade de vida e acessibilidade.

Nesse sentido, com tantas melhorias na acessibilidade, um número cada vez maior de loteamentos e melhorias das infra-estruturas da região de Praia Grande, vão sendo introduzidos serviços tais como: inauguração do Aero Club de Santos, mais conhecido como Campo da Aviação (1936), linha aérea da VASP (São Vicente - Rio de Janeiro) que saía do Campo da Aviação em Praia Grande (1948), correios (1952), rádio patrulha (1959), postos de saúde e fórum (1960), faculdade (1963), posto telegráfico (1964), entre outros. Esses acréscimos, introduzidos aos poucos em Praia Grande, vão causando uma contínua transformação da paisagem natural e quase intacta que tinha antes dos loteamentos, em uma paisagem mais urbana com uma mudança no uso e ocupação do solo nesta região de São Vicente.

Essa nova fase da exploração imobiliária em Praia Grande, por meio do turismo de segunda residência, assume novas formas, agora com o início da verticalização de suas residências, surgindo inicialmente edifícios, em média com 
04 pavimentos. Assim, desencadeia-se um processo ainda maior de valorização do solo urbano em decorrência dos investimentos em infra-estrutura e um aumento do potencial construtivo em sua região.

Sendo assim, aos poucos, não somente a forma urbana vai sendo alterada, mas também, os materiais utilizados nas construções, ou seja, até mesmo as moradias de madeira (ver foto 20 e 21) são substituídas por casas de tijolos.

Foto 20 e 21 - Moradia de madeira em Praia Grande na primeira metade do século XX
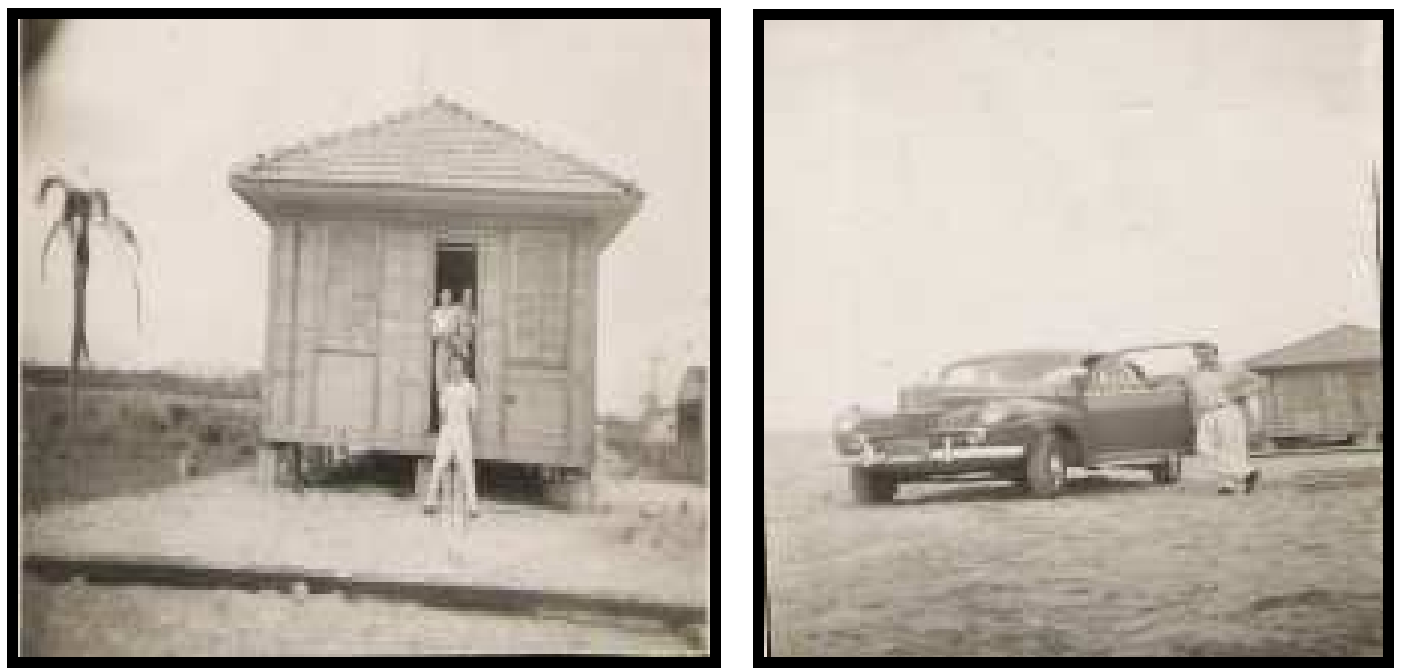

Fonte: Acervo particular de Circe Sanchez Toschi - Autor desconhecido

Esse tipo de moradia destinada à segunda residência, data da metade do século passado e era apenas um dos mais variados tipos de residências encontradas em Praia Grande. Essa moradia, em específico, era uma construção em madeira suspensa sobre alicerces de alvenaria. Em uma das fotos, temos até um morador de uso ocasional pousando para uma foto de recordação com seu carrão de frente a sua residência secundária.

Nos dias atuais, moradias de madeira nas regiões próximas a orla são muito raras, mas não impossíveis de serem encontradas (ver fotos 22 e 23). 
Foto 22 e 23 - Moradia de madeira em Praia Grande nos dias atuais
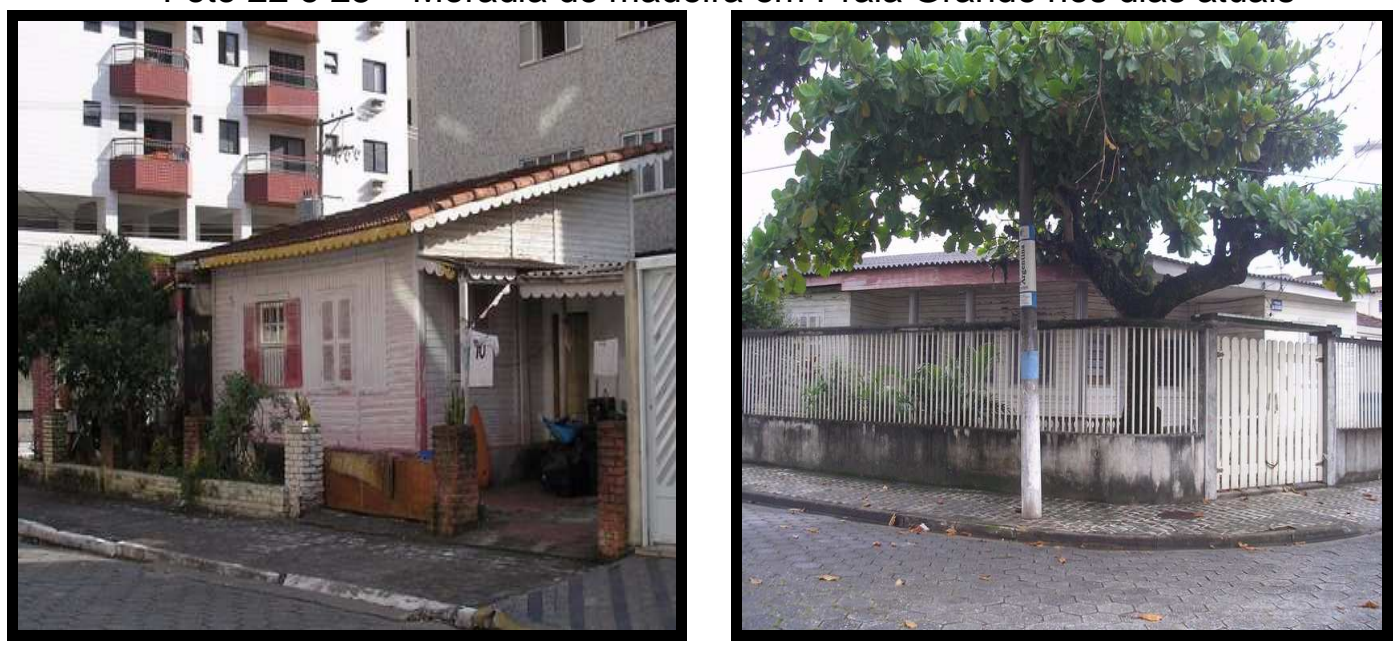

Fonte: Imário Vieira - Data: 19/01/2008 - Autor: Imário Vieira

Essas casas de madeira ainda são encontradas em alguns bairros dessa estância balneária. A moradia da foto do lado esquerdo encontra-se no Bairro do Boqueirão e a do lado direito no Jardim Guilhermina. Cabe-se ressaltar que, ainda nos dias atuais, encontramos algumas dessas casas no Jardim Guilhermina.

Ainda na década de 1950, o processo de urbanização em Praia Grande limitava-se às áreas mais próxima à orla marítima, na região que fica, nos dias atuais, entre a Rodovia Pedro Taques (SP-55) e a Estrada de Ferro com a região das praias. Dessa forma, o seu sítio urbano passava a consolidar-se nas vizinhanças e arredores da Igreja de Santo Antonio. Nesse sentido, as regiões e os terrenos mais próximos ao seu sítio urbano acabava sendo objeto de valorização. Nesse contexto, em sua tese sobre a Baixada Santista, Cíntia Maria Afonso (2006, p. 83) aponta algo interessante:

"Na década de 1950, a rodovia e a ferrovia que ligavam a Baixada Santista ao Litoral Sul serviram de obstáculo à expansão urbana, e a área urbana limitava-se à faixa contida entre elas e a praia. Somente num segundo momento esse obstáculo foi ultrapassado pela urbanização. A comparação entre a área urbana no Boqueirão e em Solemar é indicativa desse processo: na faixa litorânea mais distante de São Vicente e Santos (onde se situa o bairro conhecido como Solemar), a mancha linear contínua ocupa apenas os terrenos localizados entre a rodovia e a praia, com ocupação apenas pontual na faixa posterior à rodovia, enquanto que no Boqueirão (faixa litorânea mais próxima à llha de São Vicente) essa faixa posterior é continuamente ocupada por expansão urbana". 
Todavia, segundo a autora, as ocupações das regiões mais próximas a orla da praia e a São Vicente e Santos se deram de forma mais contínua, enquanto que nas regiões mais distantes destas duas cidades, sua ocupação se deu de forma mais descontínua. No entanto, Afonso (2006, p. 83) continua, "a urbanização também tem se estendido para as bordas urbanas junto aos morros, na área de ocupação mais antiga, mais próxima a São Vicente".

Dessa forma, as condições para especulação imobiliária vão expandindo para outras regiões mais distantes do seu sítio urbano e, com isso, ainda nos dias atuais, encontramos grandes vazios urbanos a espera de valorização. Verificamos que alguns desses terrenos estão na dependência de resolução da justiça devido a serem casos de disputas de heranças de familiares próximos.

Cabe-se ressaltar que, na década de 1950, outro fato que não beneficiava uma urbanização mais intensa para a região, era a distância de Praia Grande, com as duas únicas rodovias de acesso à região do planalto paulista. Em relação a isso, Tulik (2002, p. 53) relata que:

"O progresso de Santos, alicerçado no binômio porto-planalto, não beneficiou São Vicente, localizada à distancia das duas únicas vias de comunicação da época, existentes até meados de 1970: Caminho do Mar, Via Anchieta e estrada de ferro Santos-Jundiaí.

São Vicente permanecia, portanto, dependente de Santos para alcançar as vias que demandavam ao planalto".

A autora continua,

"Um exemplo dessa dependência é o oferecido com o caso da Via Anchieta. Inaugurada em 1947, esta via comunica, ainda hoje, São Paulo ao porto de Santos. Para acessá-la, os moradores de São Vicente, antes da implantação da Rodovia dos Imigrantes, precisavam passar por Santos". (Tulik, 2002, p. 53)

Dessa forma, embora existisse um meio de comunicação entre a região de Praia Grande e a metrópole de São Paulo e adjacências, sua ligação com a sede (São Vicente) e a cidade de Santos, ainda era muito forte, pois o paulistano que 
quisesse chegar a Praia Grande precisava passar pela área urbana de Santos e São Vicente, atravessar a Ponte Pênsil para, só então, chegar a Praia Grande. Por isso, o processo de ocupação de certas regiões de Praia Grande ainda era incipiente nesta época.

Um importante fato na história da cidade e para o turismo local foi a inauguração do Restaurante Lagosta ${ }^{40}$ (ver foto 24) em 01 de julho de 1952. Este restaurante ficou famoso por atrair turistas para Praia Grande, por suas instalações luxuosas e por receber ilustres personagens nacionais e internacionais da época. Segundo Dona Circe Sanchez Toschi, filha do proprietário, Heitor Sanchez, ele foi "um marco de elegância e bom gosto, o Lagosta recepcionava importantes celebridades ${ }^{41}$ de nosso estado e país, e ainda, delegações estrangeiras que desembarcavam no porto de Santos".

Magalhães (1965, p 73) nos relata alguns dos aspectos gerais da Praia Grande, no final da década de 1950 e início da década de 1960, como segue:

“(..) nota-se perfeitamente que não há continuidade das edificações. Estas se juntam em grupos isolados entre si, e, a três ou quatro quadras da orla litorânea, normalmente, não mais se encontram residências, salvo nos núcleos já referidos.

As construções, em sua quase totalidade térreas, são de tijolos de cimento, sem dúvida alguma por ser material mais acessível no preço e de mais fácil manuseio, que permite menor dispêndio na mão-de-obra, cara no local, pois os pedreiros, procedendo geralmente de Santos e mesmo São Paulo, devem ter um salário maior que o normal da região.

As moradias não merecem melhor tratamento ou cuidado por parte dos proprietários, oferecendo aspecto pouco favorável no conjunto.

É junto à Avenida Beira-Mar e jamais para o interior, a não ser próximo ao Boqueirão, que se acham os poucos edifícios de apartamentos construídos ou por construir".

\footnotetext{
${ }^{40}$ Cabe-se lembrar que, o projeto desse restaurante foi criação dos engenheiros Tinoco e Pivatelli, e foi para os padrões da época, uma revolução de projeto arquitetônico pelo design arrojado, tanto interno e quanto externo.

${ }^{41}$ Segundo Dona Circe Sanchez Toschi, entre as celebridades que visitavam Praia Grande, nesta época, estavam Mazzaropi e sua mãe, Dona Clara, que tinham uma casa na Av. Mathilde. Além destes, também freqüentavam o Lagosta: Izaurinha Garcia, Hebe Camargo, Adhemar de Barros, Ulisses Guimarães, Lucas Nogueira Garcez, Jânio Quadros, Laudo Natel, cônsules de várias nacionalidades e tantos outros.
} 
Foto 24 - Restaurante Lagosta na década de 50

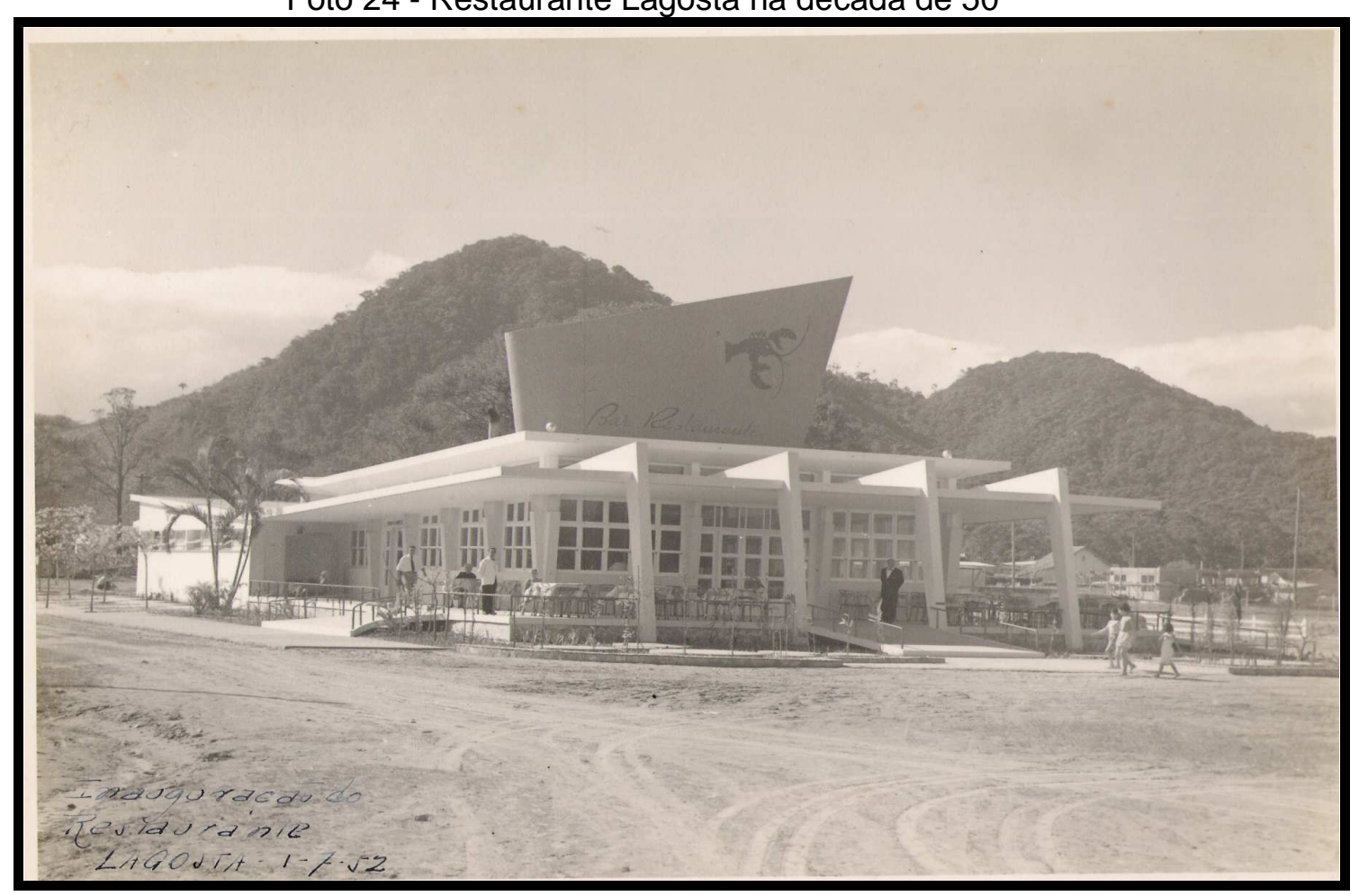

Fonte: Acervo particular da Dona Circe Sanchez Toschi. Autor desconhecido

Este restaurante foi um projeto que, na época, surpreendeu por seus traços modernistas. Na década de 1950, ele foi, em muitas ocasióes, um ponto de encontros de grandes personalidades do cenário social e político, tanto regional quanto nacional.

Sendo assim, foi justamente nesta época, entre 1950-1960, que Magalhães (1965, p. 73) menciona que o processo de verticalização, iniciado na metade da década de 1940, passa a tomar força em alguns bairros mais próximos ao centro, nas regiões mais próximas a Santos e São Vicente, que começam a ter sua paisagem mudada com a introdução de prédios de, no máximo, 4 andares. Contudo, quando o autor cita que não mais se encontram residências, salvo nos núcleos já citados, estava se referindo que em algumas áreas, ainda mantinha-se parte da vegetação nativa da Mata Atlântica. Até os dias atuais, seguindo para o oeste do balneário de Praia Grande em direção a Mongaguá, percebemos que, do lado direito da SP 55, há muitas áreas, onde a exploração imobiliária ainda não 
chegou. Nessa época, havia bairros nos quais ainda não existiam prédios e havia apenas poucas casas, o Jardim Mathilde era um deles (ver foto 25 e 26).

Foto 25 - Loteamento do Jardim Mathilde em fevereiro de 1947

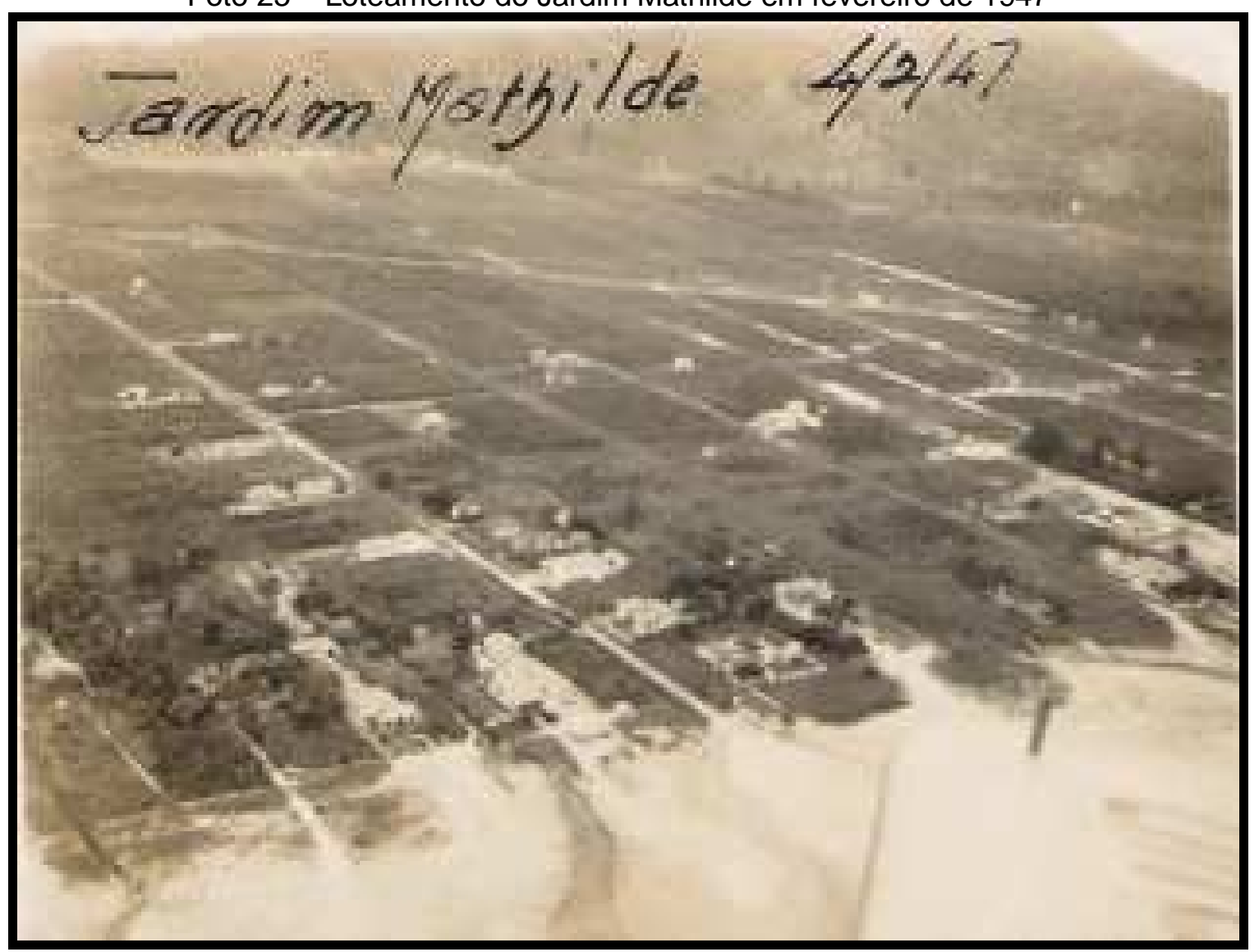

Fonte: Acervo particular de Circe Sanchez Toschi - Autor desconhecido

Embora essa foto não seja de boa qualidade, dá para termos uma idéia de como era esse bairro do Distrito de Praia Grande na segunda metade do século passado. O Jardim Mathilde foi um bairro idealizado para a construção de casas de veraneio. Dessa forma, como podemos verificar por meio dessa foto, tirada em 1947, este bairro ainda não contava com a presença de prédios ou construções verticalizadas e possuía muitas áreas para serem loteadas e construídas. Cabe-se ressaltar que, no fundo desse loteamento, quase junto ao Morro Xixová, ficava uma olaria que foi utilizada para a aquisição de tijolos que foram usados nas diversas construções de residências fixas e ocasionais dessa região vicentina. 
Foto 26 - Loteamento do Jardim Mathilde em março de 1947

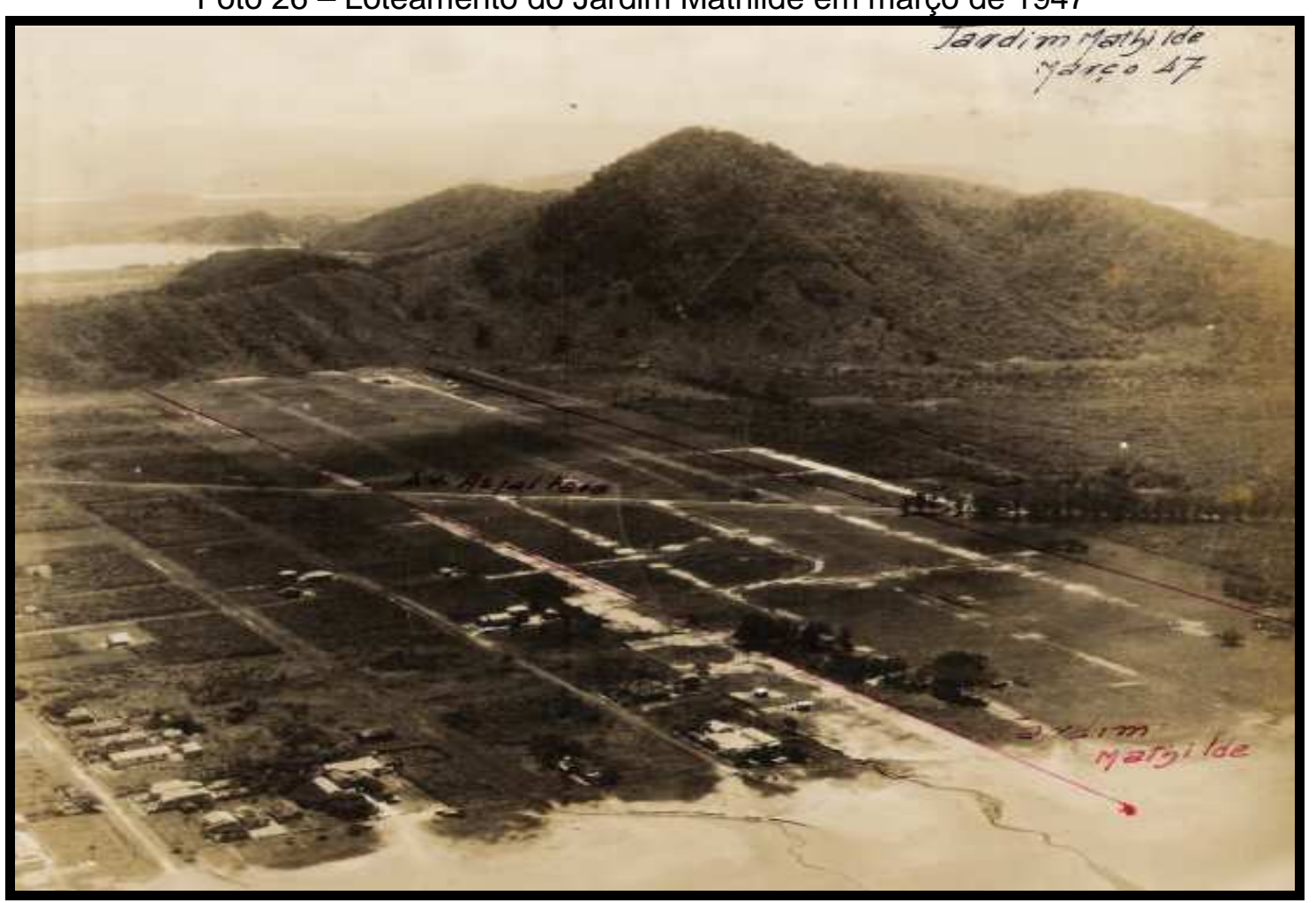

Fonte: Acervo particular de Circe Sanchez Toschi. Autor desconhecido

Nesta foto vemos que quase não há continuidade de habitações e a completa inexistência de prédios nas imediações do Jardim Mathilde.

Além do mais, dando início a essa nova forma urbana, dois dos primeiros prédios da região de Praia Grande, foram o Xixová e o Shangri-lá. Esses dois edifícios foram construídos na metade da década de 1940, iniciando o processo de verticalização praiagrandense. Assim, o primeiro prédio a ser erigido no Jardim Guilhermina foi o Xixová (ver figura 12) com doze apartamentos e com o lançamento de sua pedra fundamental em 16 de janeiro de 1944. Foi seguido pelo segundo prédio a ser construído de nome Shangri-lá (ver figura 13) e com 18 apartamentos. Em uma matéria do jornal O Correio da Manhã (O CORREIO DA MANHÃ, São Vicente, 27 fev. 1944. Capa.) anuncia apartamentos em condomínio no Jardim Guilhermina com o lançamento da pedra fundamental anunciada em 27 de fevereiro do mesmo ano. Ele foi construído na Avenida Ipanema, no Jardim Guilhermina. 
Figura 12 - Anuncio do Prédio Xixová

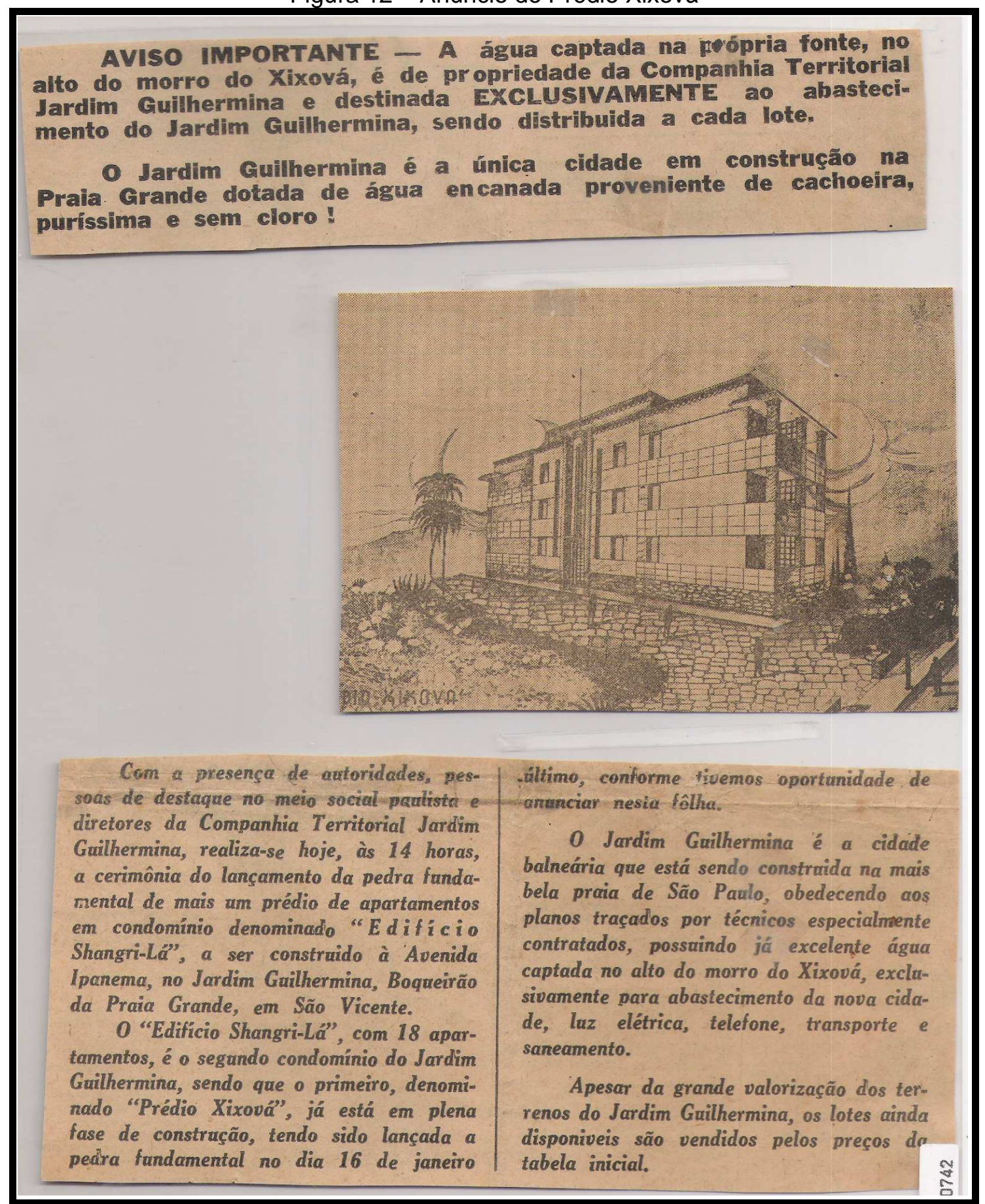

Fonte: Arquivo pessoal de Dona Circe Sanchez Toschi

Nessa matéria, vemos algo interessante, ou seja, o Jardim Guilhermina sendo tratado como uma cidade balneária em construção, e não como um conjunto habitacional do ainda distrito de São Vicente. Essa construção contava com água encanada vindo de fonte própria do Morro Xixová e destinada exclusivamente ao uso dos proprietários de lotes dentro do Jardim Guilhermina. 
No entanto, foi junto com as construções e verticalizações que se seguiam que vieram outras obras de importância para a produção do espaço urbano em Praia Grande. Nesse contexto, de acordo com um documento do arquivo pessoal da Dona Circe Sanchez Toschi, em 1954, junto com a colocação da pedra fundamental da Avenida Beiramar (ver foto 27) que também foi dado início à instalação dos primeiros 700 metros de água potável da cidade de Praia Grande, com a conclusão prevista para o mês de junho de 1954. A obra foi financiada em cooperação com o governo e os proprietários de terras da região por meio da Associação dos Amigos de Praia Grande.

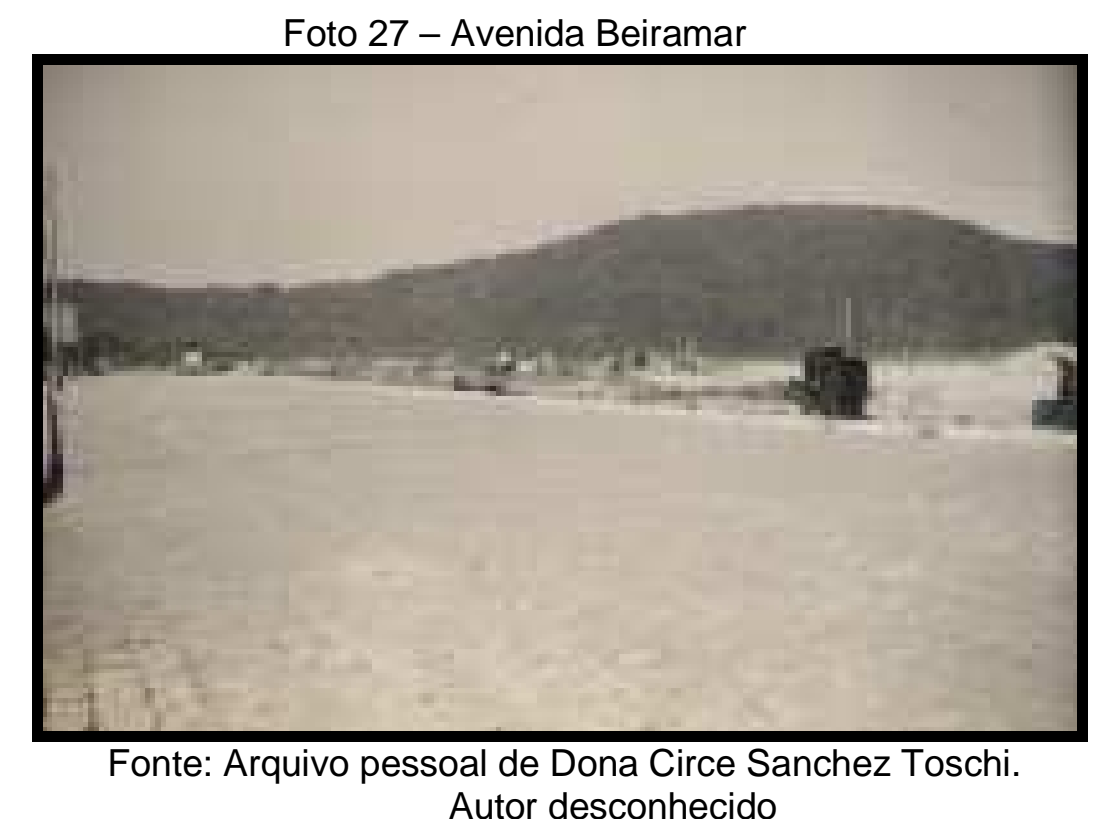

A construção do primeiro trecho da Avenida Beiramar foi a realização de um antigo sonho dos primeiros pioneiros que acreditaram em Praia Grande, ou seja, a construção de uma estrada ligando toda a orla marítima, de um canto ao outro.

Vale lembrar que o crescimento industrial e urbano da atual região metropolitana de São Paulo na metade do século passado favoreceu, de forma significativa, o crescimento do turismo de segunda residência em Praia Grande e Baixada Santista. Camargo (2003, p.57), em sua dissertação sobre "A Geografia 
das lutas metalúrgicas no ABC Paulista na virada dos anos 70 do Século XX", informa:

"Numa nova fase de crescimento industrial e urbano seria observada na região [do $A B C$ ] em meados dos anos 50 , no contexto de um redirecionamento da industrialização no país, um dos pontos de honra do chamado Plano de Metas sob o governo de Juscelino Kubitschek".

Portanto, esse crescimento industrial e urbano do $A B C$ e também da metrópole de São Paulo foi acompanhado por um crescimento do poder econômico, financeiro e também da sua população e isso muito beneficiaria o aquecimento da demanda por segundas residências em áreas litorâneas como as de Praia Grande.

Ainda, aliado à construção da Avenida Beiramar e dando mais força a todo este conjunto de transformações que indiretamente beneficiariam a exploração imobiliária, tínhamos também a construção da Rodovia Padre Manoel da Nóbrega, entregue em 1961. Dentro desse contexto, com o início de sua construção, este distrito de São Vicente, passou a receber um grande número de trabalhadores que se deslocava todos os dias para esse balneário para trabalhar nessa construção e em outras obras de grande importância, o que não impossibilitava a fixação de residência desses trabalhadores em Praia Grande. Desse modo, um incremento na população por meio da migração de trabalhadores que vinham prestar serviços na área da construção civil nessa estância balneária.

Vale ressaltar que, com tantas melhorias que iam se fazendo presentes nos meios de comunicação dentro de sua região, Praia Grande ia se expandindo para outras regiões mais distantes da região do Jardim Guilhermina. E assim, devido à terra ter sido transformada em mercadoria, a exploração imobiliária, por meio da segunda residência, ia se intensificando nesse distrito de São Vicente.

No entanto, Tulik (2002, p. 58) fundada em Seabra, nos diz que "o processo de ocupação pelas segundas residências acentuou-se nos anos 60 em toda a Baixada Santista". Assim, Praia Grande não foi uma exceção a esse processo que Tulik (2002, p. 58) menciona e todo esse contexto de verticalização que estava sendo introduzido por meio da acentuação das segundas residências na Baixada 
Santista foi acompanhado de outras transformações no ramo da construção e exploração imobiliária, como por exemplo, com os materiais que vão sendo substituídos. Magda Starke Lee, em sua dissertação "Balneário de Camboriú: desenvolvimento de uma cidade litorânea", menciona algo interessante que se aplica à realidade de Praia Grande nessa época; ao indicar fundada em Campos, que "ocorreu também grande mudança na forma de construir. O material utilizado para as construções passou a ser de concreto armado" (Lee,1998, p. 77). Lee (1998, p. 78), ainda, afirma que:

\begin{abstract}
"Neste sentido, a nova prática de construir tomou a forma de construção por incorporação, a qual passou a incorporar outras atividades com a aquisição de terrenos e a divulgação e comercialização dos imóveis, além de realizar a construção em sí".
\end{abstract}

A autora faz menção a uma nova prática de construir, a construção por incorporação que também teve sua presença e atuação no distrito de Praia Grande. Desse modo, com a introdução de novos personagens no ramo da construção civil, o processo de verticalização deu um grande salto na segunda metade da década de 1950 e isto se deu devido à construção do Conjunto Habitacional Cidade Ocian $^{42}$ pela Organização Construtora e Incorporadora Andraus Ltda.

Assim, Suzuki (1996, p. 165), quando fala da introdução dos conjuntos habitacionais na cidade de Rondonópolis, também nos informa sobre o surgimento de novos sujeitos no ramo da construção civil:

“(...) quando os conjuntos habitacionais começam a ser construídos, não são mais poucas pessoas ou instituições que se envolvem, mas um complexo emaranhado, para o qual é necessária uma especialização cada

\footnotetext{
${ }^{42}$ A palavra Ocian é uma sigla: Organização Construtora e Incorporadora Andraus. Como diz no site http://www.apraiagrande.com.br/historiapraiagrande/index.asp de Praia Grande, "Na época, a Praia Grande era um bairro de São Vicente, com poucos serviços urbanos. A construção dos prédios trouxe para cá uma infra-estrutura que não havia na região. Foram instalados geradores de energia elétrica, que funcionavam com óleo diesel, sistema de coleta e tratamento de esgotos e água encanada. Lojas, padarias e um próspero comércio passaram a ser estimulados por moradores e turistas".
} 
vez maior, já que a escala de produção passa a ser outra. Dessa forma, surge um amplo espectro de promotores imobiliários: incorporadores, investidores, construtores, corretores e estudiosos".

Portanto, a partir dessa década, a prática de construção vai se transformando com a introdução destes "novos personagens do mercado da exploração imobiliária" ${ }^{\prime 3}$, e com eles, a paisagem natural vai sendo cada vez mais transformada.

Assim, em seu trabalho sobre o Balneário de Camboriú, Lee (1998, p. 76) nos dá um relato sobre a introdução destes novos personagens no ramo da construção civil e que tiveram sua atuação também em Praia Grande. Ela nos relata:

"Com a instalação das empresas de construção civil, a antiga prática de construção de casas de veraneio foi substituída pela nova maneira de construir. Já não se construía mais uma casa isolada, mas sim prédios de apartamentos para vários proprietários. Transformaram-se também as relações entre construtor e o proprietário, uma vez que o novo caráter empresarial assumido pela construção civil criou novos personagens até então inexistentes. É o caso do engenheiro de obra e do projeto, do arquiteto, do incorporador e do agente imobiliário. Estes personagens fazem parte de um contexto de mudanças, em que as relações e a apropriação do espaço também se modificam".

Em Praia Grande, o primeiro conjunto habitacional utilizando estes "novos personagens" da construção civil foi o conjunto habitacional Cidade Ocian. Esse conjunto foi um grande empreendimento da cidade que, em 1954, com grandes tapumes de madeira que davam de frente para o mar, a Organização Construtora e Incorporadora Andraus Ltda (cuja sigla era OCIAN, nome do empreendimento) anunciava a venda de apartamentos a partir de $\mathrm{Cr} \$ 2.000,00$ (dois mil cruzeiros) de entrada e Cr\$990,00 (novecentos e noventa cruzeiros) mensais. Esse empreendimento tem um conjunto de 22 prédios com um total de 1350 apartamentos.

${ }^{43}$ Engenheiro de obra e do projeto, arquiteto, o incorporador e o agente imobiliário. 
Dessa forma, a Construtora e Incorporadora Andraus mandou imprimir panfletos e divulgou seu lançamento em jornais, rádios e principais mídias da Baixada Santista e São Paulo. Várias pessoas de nossa própria família foram compradores desses apartamentos do Conjunto Habitacional Cidade Ocian, que era para época, uma revolução em segunda residência, oferecendo tudo que havia de mais moderno em um só lugar.

Desse modo, como estava escrito em seus panfletos (ver figura 14 e 15), a Organização Construtora e Incorporadora Andraus Ltda vendia a idéia de que "a CIDADE OCIAN era auto-suficiente" e que reunia, sozinha, o que muitas cidades levariam anos e anos para conseguir, tais como: água, luz, esgoto, sistema próprio de tratamento de esgoto, telefone, igreja, escola, mirante, núcleo comercial, agência do Banco Brasileiro de Descontos S.A. (BRADESCO), jardins, isenção de imposto territorial, estacionamentos, valorização garantida, ônibus da Viação Cometa direto de São Paulo à Cidade Ocian, bomba de gasolina, táxi, dentre outros serviços. Enfim, era como seus idealizadores queriam, "uma verdadeira cidade", com toda a infra-estrutura para proporcionar conforto aos seus investidores.

Por tudo isso, em 1956, o Conjunto Habitacional Cidade Ocian foi considerado "a cidade mais bem planejada e moderna do Brasil, só perdendo esse título no dia 21 de abril de 1960, com a inauguração de Brasília"44. Percebemos, pela matéria, que até este bairro, era cognominado de "cidade", algo muito incomum.

Vale enfatizar que, de acordo com o novo Plano Diretor com vigência de 2007 a 2016 (PRAIA GRANDE, Prefeitura Municipal. Lei Complementar nํ 473, de 27 de dezembro de 2006), o conjunto habitacional Cidade Ocian foi um importante marco para a história desta cidade-média paulista:

"A construção do conjunto de prédios está intimamente ligada à história da cidade, por terem sido os primeiros edifícios residenciais erigidos. Inaugurados em 1956, tiveram caráter pioneiro, pois conjuntamente à construção dos prédios, foram implantados todos os equipamentos de infra-

\footnotetext{
44 Informação disponível em: http://www.novomilenio.inf.br/pg/pgh020.htm. Acesso em 10/11/2007, por Imário Vieira
} 
estrutura necessários, desde as redes de abastecimento de água, passando pelo posteamento e rede de iluminação elétrica, até a criação de um sistema de tratamento de esgoto próprio".

Assim, para essa época, o Conjunto Habitacional Cidade Ocian representava o que havia de mais moderno no ramo da construção civil e da exploração imobiliária trazendo em sua concepção e idealização toda a infra-estrutura necessária para seus investidores.

Portanto, devido às dimensões que a oferta e demanda por imóveis de segunda residência assumiram nesta região de São Vicente, é nessa década que Praia Grande apresenta a mais significativa mudança no padrão do uso do solo e apropriação do espaço em sua região. No princípio do século XX, o uso dos terrenos destinava-se apenas à construção de casas e pequenas chácaras para uso ocasional destinados ao lazer de suas famílias. Nessa época, os proprietários de residências em Praia Grande apropriavam-se do espaço para seu próprio uso, não para alugarem o mesmo em temporadas de verão e férias para pessoas estranhas por meio de anúncios em jornais, ou como é feita nos dias atuais, ou seja, por meio da Internet. Assim, aos poucos, outra transformação passa a ocorrer em Praia Grande: a passagem do espaço produzido como valor de uso, para um espaço que se reproduz visando a realização do valor de troca. Tal processo, também assemelha-se ao que ocorreu em Santos, São Vicente e outras estâncias balneárias de nosso estado e país.

Desse modo, com tantas mudanças e melhorias que iam sendo implantadas, Praia Grande preparava-se para um surto de crescimento urbano e um boom de novas moradias verticalizadas que, a partir da construção da Via Anchieta e com a acumulação de capital que a população de nosso estado passava a ter, aumentou a busca por tais empreendimentos, principalmente, pela população da metrópole de São Paulo e adjacências. Cabe-se ressaltar que um importante fato para todo esse crescimento do incentivo ao turismo litorâneo de segunda residência foi a melhoria dos meios de circulação. 
Figura 14 - Propaganda do Conjunto Habitacional Cidade Ocian (frente)

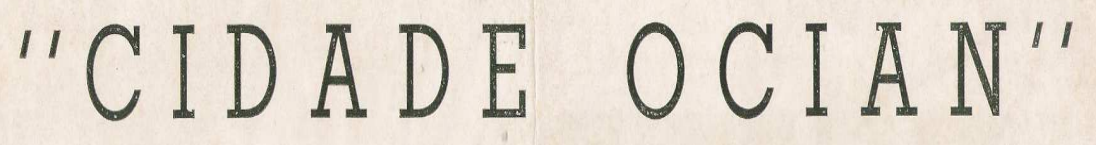

$P R A \mid A \quad G R A N D E$

Seu sonho realizado na maior e mais linda praia do mundo!!!

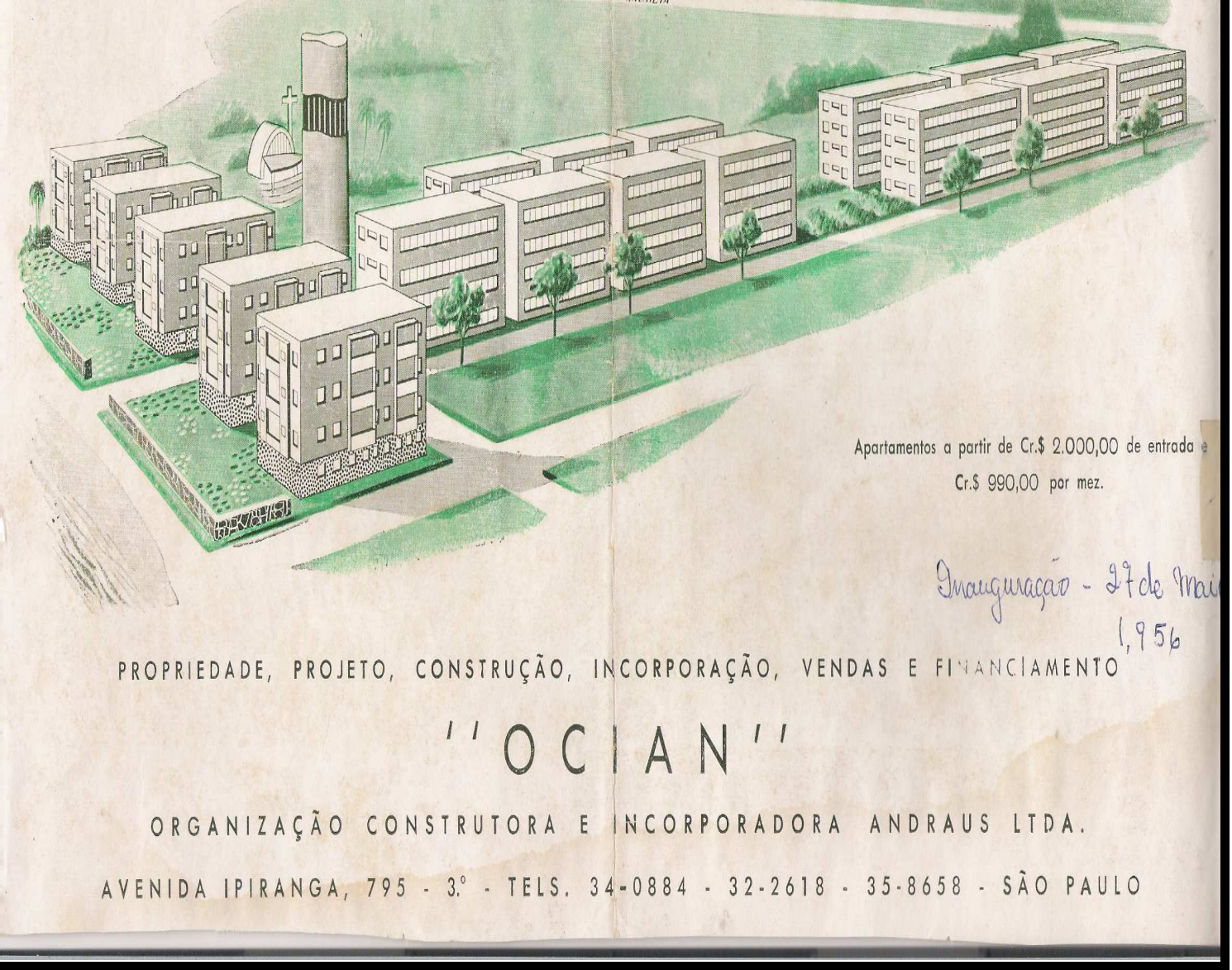

Fonte: Arquivo pessoal de Dona Circe Sanchez Toschi

Essa fonte iconográfica nos mostra a propaganda do que seria para época, um conjunto cidade densa verticalizada, com áreas para uso coletivo, com espaçamento entre os blocos para ventilação e iluminação. Esse conjunto, na década de 50, representou uma verdadeira revolução na arte de construir e por sua modernidade. 
Figura 15 - Propaganda do Conjunto Habitacional Cidade Ocian (verso)

Pela nova estrc is saindo de Cubatão, V. S. chegará antes á Cidade Ocian do que em Santos ou São Vicente.

PLANTA DE LOCALIZAÇÃO

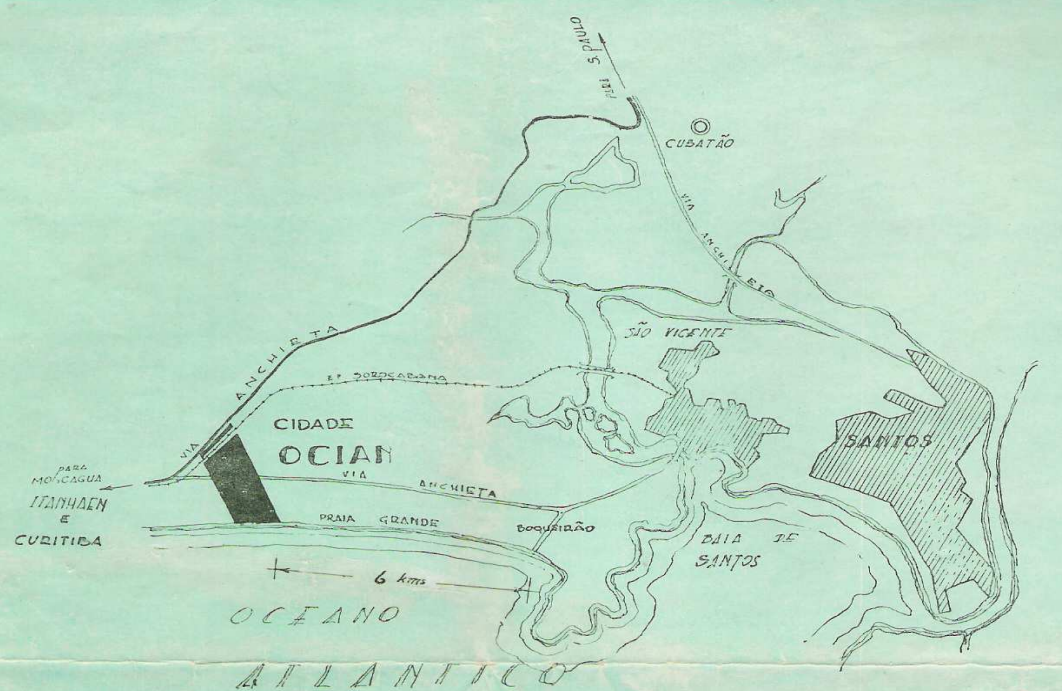

\section{A CIDADE «OCIAN»}

é auto-suficiente e reune, sozinha o que muitas cidades levaram anos e anos para obter.

1) Agua - 2) Luz - 3) Esgoto - 4) Telefone - 5) Igreja

6) Escola - 7) Mirante - 8) Nucleo Comercial

9) Agencia do Banco Brasileiro de Descontos S. A

10) 150 metros de Jardim de frente para o mar.

11) Zeladorias evitando roubos comuns em casas sem caseiro.

12) Isenção de Imposto territorial

13) Provavel isenção de imposto predial

14) Prestações inferiores á de muitos terrenos, em inferior localização.
15) Despezas minímas de Condomínio garantidas pela Ocian que já administra mais de 1.000 apariamentos.

16) Varias arecs para estacionamento de automoveis.

17) Valorização garantida.

18) Onibús da Viação Cometa direto de São Paulo à Cidade Ocian.

19) Apartamentos de frente para o mar e com vista para o mar.

Preço fixo sem recjuste.

21) Prazo maximo de entrega 24 mezes aproximadamente.

22) Bomba de Gazolina - 23) Ponto de Taxi.

Futuras Linhas Aéreas Ligando a Ciciade Ocian a todo o Interior

Qualquer dos itens acima garantem um extraordinário emprego de capital para si e sua família.

Esse Conjunto habitacional reunia tudo que muitas cidades não tinham nessa época, ia desde o saneamento básico a toda infra-estrutura e até benefícios de isenção do IPTU. 
Todavia, Barreiros (2002, p. 9) atenta ao fato de que, a partir da década de 1950, com o desenvolvimento econômico do pós segunda guerra mundial e com a industrialização crescente do estado, impulsionada pelo desenvolvimento da indústria automobilística, a Via Anchieta, inaugurada em 1947 (ver foto 28) começa a apresentar sinais de saturação, demandando por outros objetos técnicos para desafogar a mesma. É a partir desse desenvolvimento pelo qual passa nosso estado que novas vias de acesso vão sendo construídas e que vão favorecendo, não somente à Praia Grande, mas toda a Baixada Santista.

Na década de 1960, foi a vez da Rodovia Padre Manoel da Nóbrega (cognominada de Estrada da Banana) ${ }^{45}$ entregue em 1961, reduzindo as distâncias com os pólos emissores de turismo da região do Planalto Paulista e da Baixada Santista.

É nesse mesmo cenário de desenvolvimento dos meios de circulação que surge, para a classe media paulista, a chance de comprar seu imóvel de uso ocasional ou até mesmo permanente, só que agora em prédios e com condições facilitadas pelos financiamentos a longo prazo (ver figura 16 e 17).

Assim, também surge, nessa época, com a verticalização e com um maior fluxo de pessoas para a região praiagrandense, o transporte coletivo intermunicipal, com o sucesso das linhas intermunicipais da Empresa Expresso Brasileiro Viação Ltda e da Viação Cometa. Nessa época, a importância do ônibus aumentava, principalmente, por alcançar destinos estranhos ao transporte ferroviário e permitir a mobilidade para lugares de lazer, possibilitando às pessoas de classe média o acesso a lugares turísticos litorâneos.

45 Disponível em: http://www.pedrodetoledo.sp.gov.br/historico.htm - Acesso em 23/12/2006. Por Imário Vieira. Este site menciona que a Rodovia Padre Manoel da Nóbrega era cognominada de Estrada da Banana. 
Foto 28 - Via Anchieta logo após a sua inauguração em 1947

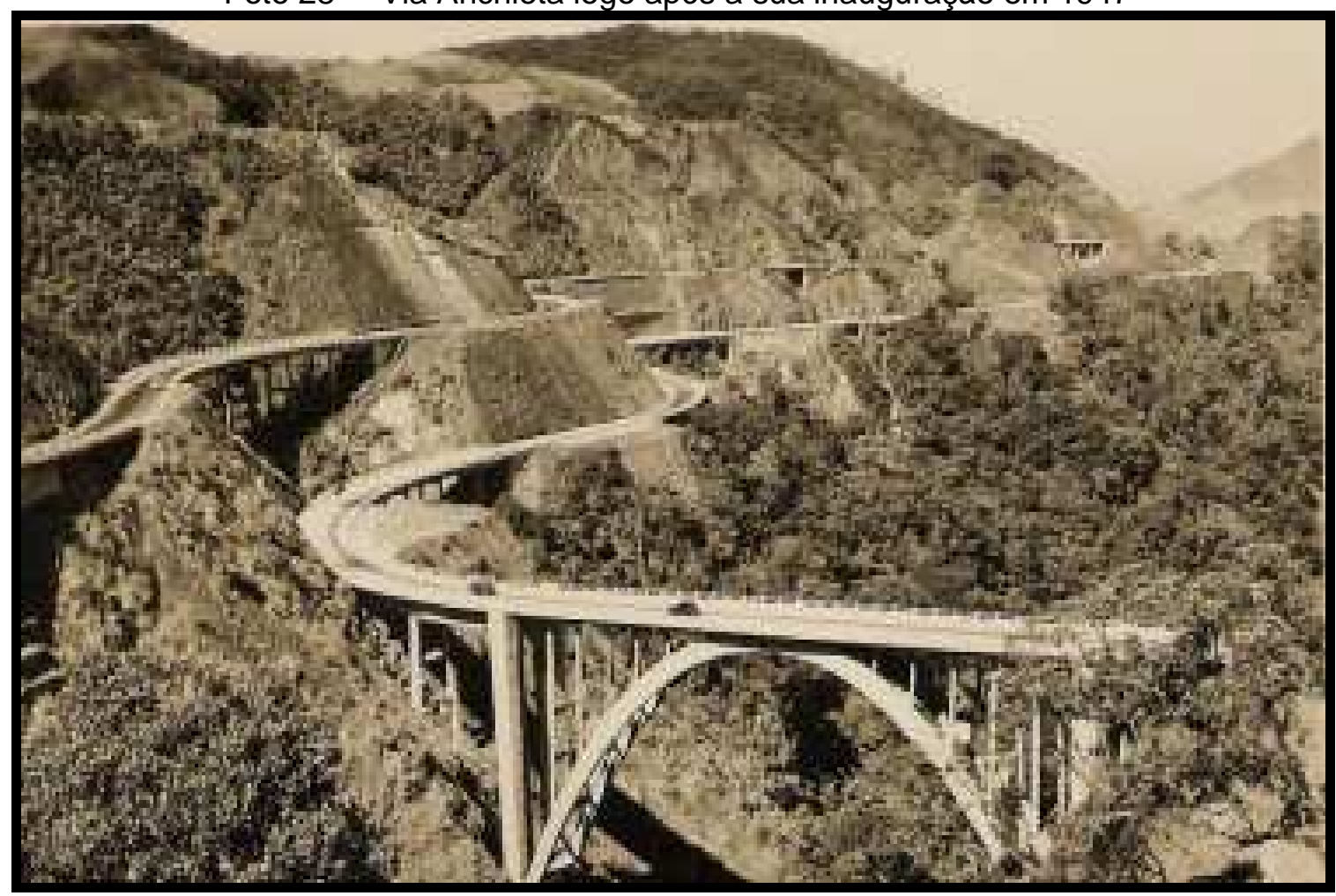

Fonte: Arquivo pessoal de Dona Circe Sanchez Toschi

Nessa foto, vemos a Via Anchieta logo após sua inauguração em 1947, com suas pontes modernas. Sua construção foi um projeto inovador e audacioso para a época.

Ainda no princípio da década de 1950, os moradores do distrito de Praia Grande se ressentiam com a sua sede em São Vicente e pelo descaso que tinham com suas necessidades de infra-estrutura, por isso começava entre os habitantes de Praia Grande um movimento para sua emancipação, o qual trataremos com mais detalhe no próximo capítulo.

Entre o final da década de 1950 e início de 1960, Guimarães (1965, p. 70) nos diz que o balneário de Praia Grande "é ligado à sede por meio de ônibus e trens, que demandam Mongaguá e Itanhaém, e pelo ônibus que fazem o percurso Cidade Ocian-São Vicente e Boqueirão-São Vicente". Apesar das melhorias no sistema de transporte, todo o resto ainda tinha situação muito precária e carente de infra-estrutura básica. 
Figura 16 - Propaganda do Condomínio Santa Tereza (frente)

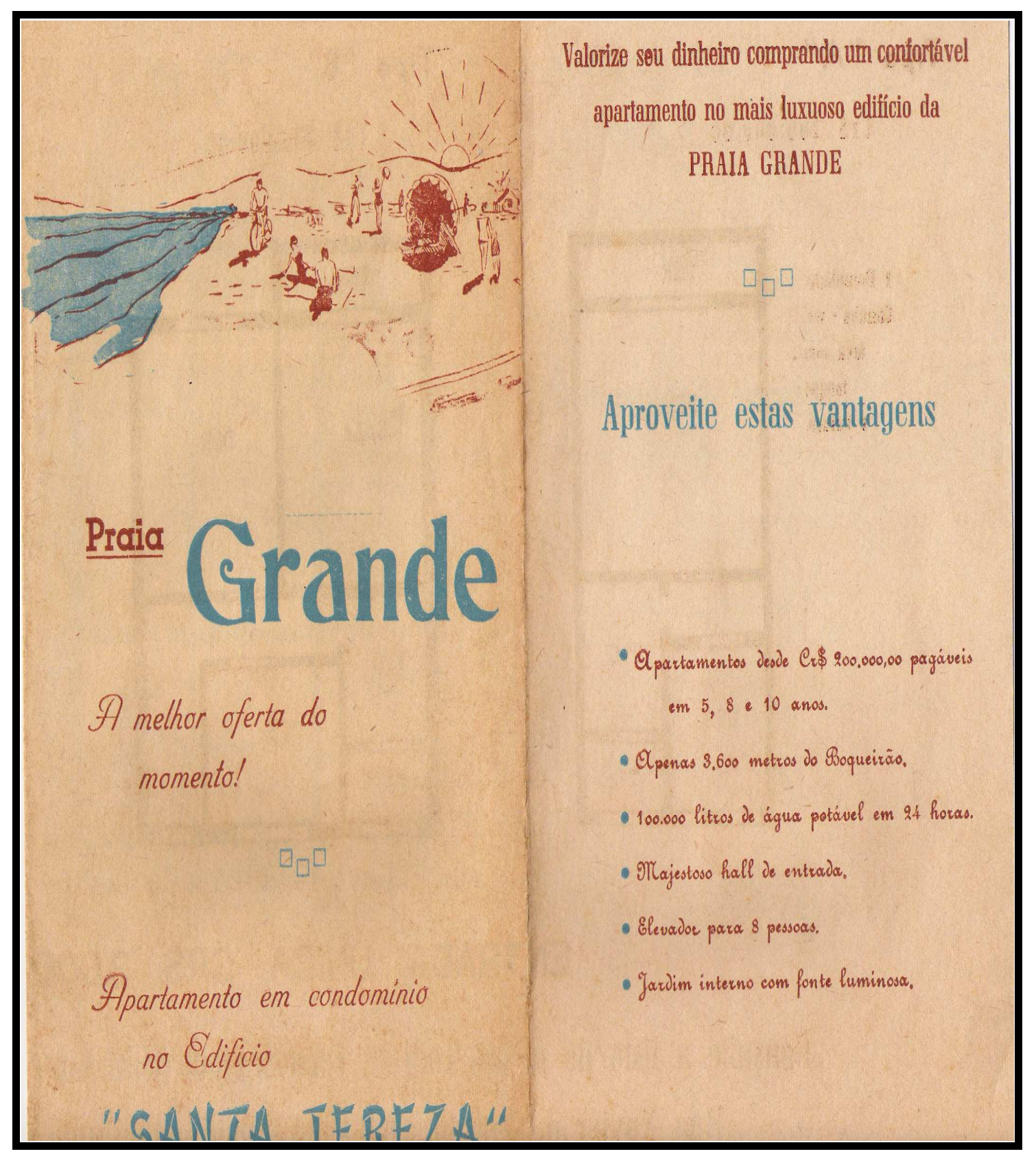

Fonte: Arquivo pessoal de Dona Circe Sanchez Toschi

Vemos nessa propaganda do Edifício Santa Tereza que as condições de financiamento eram feitas em 5, 8 ou até 10 anos. 
Figura 17 - Propaganda do Condomínio Santa Tereza (verso)

$$
\text { Tipo "A" }
$$

Crs $200.000,00$
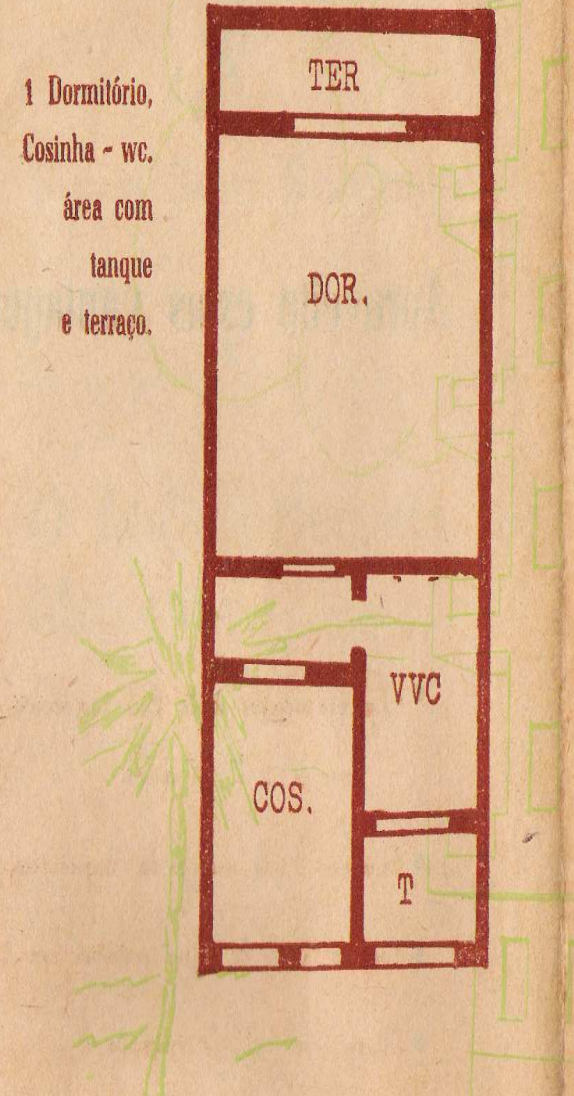

Tipo "B"

Crs $330.000,00$

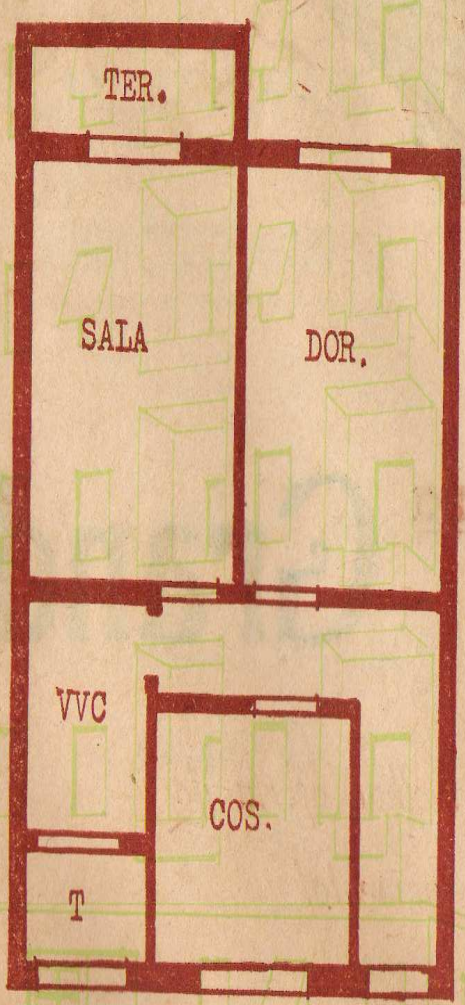

1 Dormitório - sala - wc. - cosinhla - área com tanque e terrą̧o

\section{ENTRADA UNICA CR\$ 3.000,}

Consulte a lista de preços com os corretores no local ou n Rua Xavier de Toledo, 264 = 8.0 andar - Coniunto

Fonte: Arquivo pessoal de Dona Circe Sanchez Toschi

Esse edifício tinha dois modelos de apartamentos que apresentavam variações nos tamanhos dos cômodos e sacadas e ainda com ou sem sala-de-estar. 
Desse modo, o crescimento vertical que, até então, era pouco expressivo em Praia Grande, aos poucos vai aumentando, novos loteamentos vão aparecendo e mudanças importantes vão ocorrendo na região vicentina. Entre essas várias mudanças, o comércio vai se desenvolvendo, a região urbana vai se expandindo e se urbanizando, melhoram os serviços básicos de fornecimento de energia elétrica, redes de esgoto, de fornecimento de água potável, rede de transportes e calçamento de ruas. Nessa época, também, se intensificam os serviços com o aparecimento de um número maior de lojas, açougues, escolas, farmácias, padarias, postos de gasolina etc, e, em conseqüência disso, aumenta consideravelmente o número de habitantes.

Sendo assim, dando seguimento à presença marcante dessa nova forma urbana em Praia Grande, a partir do final da década de 1960 e princípio da década de 1970, a verticalização vai se intensificando em sua região, mesmo que ainda de forma incipiente e com poucos prédios acima de quatro andares. Assim, os prédios e condomínios de apartamentos vão, aos poucos, se espalhando pela paisagem do ainda distrito de São Vicente (ver foto 30).

No entanto, Magda Starke Lee (1998, p. 73), em sua dissertação sobre o Balneário de Camboriú, diz algo interessante sobre a segunda moradia e que se aplica no caso de Praia Grande. Ela nos dá a sua contribuição dizendo que "a segunda residência tipo apartamento, emergiu como uma nova opção para a casa de veraneio (...)". Em Praia Grande, essa nova opção teve grande aceitação e foi um grande incentivo à construção civil.

Na década de 1970, o desenvolvimento do ramo da construção civil em Praia Grande e em todo território nacional tem um grande incentivo com a Lei 5741/ 71 do governo de Emílio Garrastazu Médici, que instituiu o Sistema Financeiro de Habitação. 
Foto 29 - Edifício do final da década de 1960

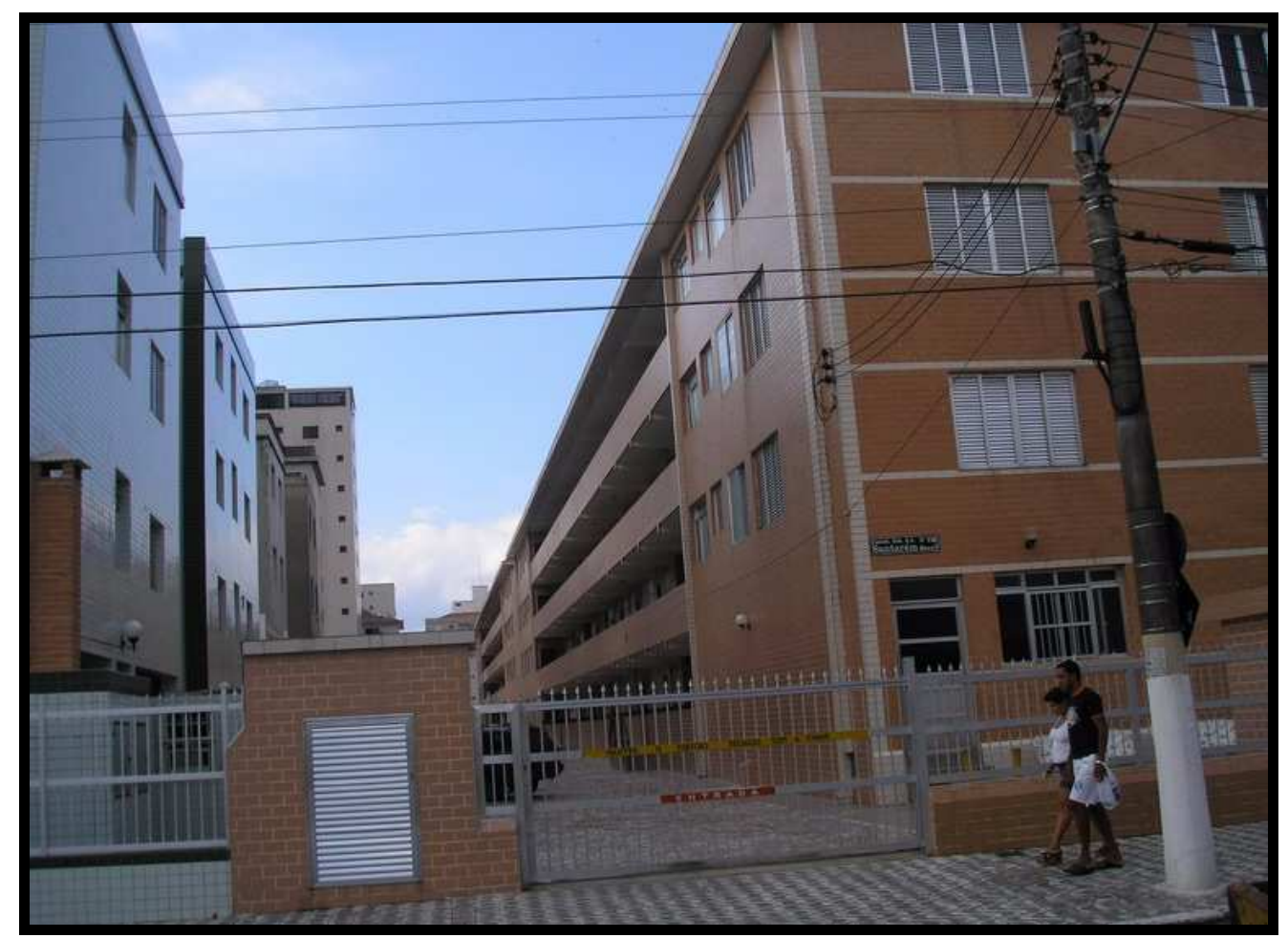

Fonte: Imário Vieira - Data: 20/06/2007 - Autor: Imário Vieira

Nessa foto, vemos um dos vários modelos de edifícios que eram típicos da década de 60. Eles caracterizavam-se como edifícios retangulares, de no máximo 04 andares e com corredores laterais para proporcionar uma maior ventilação e iluminação dos apartamentos. Eram prédios de vasta extensão e, em geral, poucos deles tinham vagas para estacionamento e quando tinham, não eram subterrâneas.

Conforme já falamos, vale lembrar que, um fator que favoreceu o turismo de segunda residência e o ramo da construção civil em Praia Grande foi a melhoria dos meios de circulação. Dentro desse contexto de melhoria dos meios de circulação, em 28 de junho de 1976, com a conclusão da primeira pista da Rodovia dos Imigrantes, a ligação entre a Grande São Paulo e a Baixada Santista tornou-se mais fácil. 
Foto 30 - Região central com poucos prédios acima de 04 andares

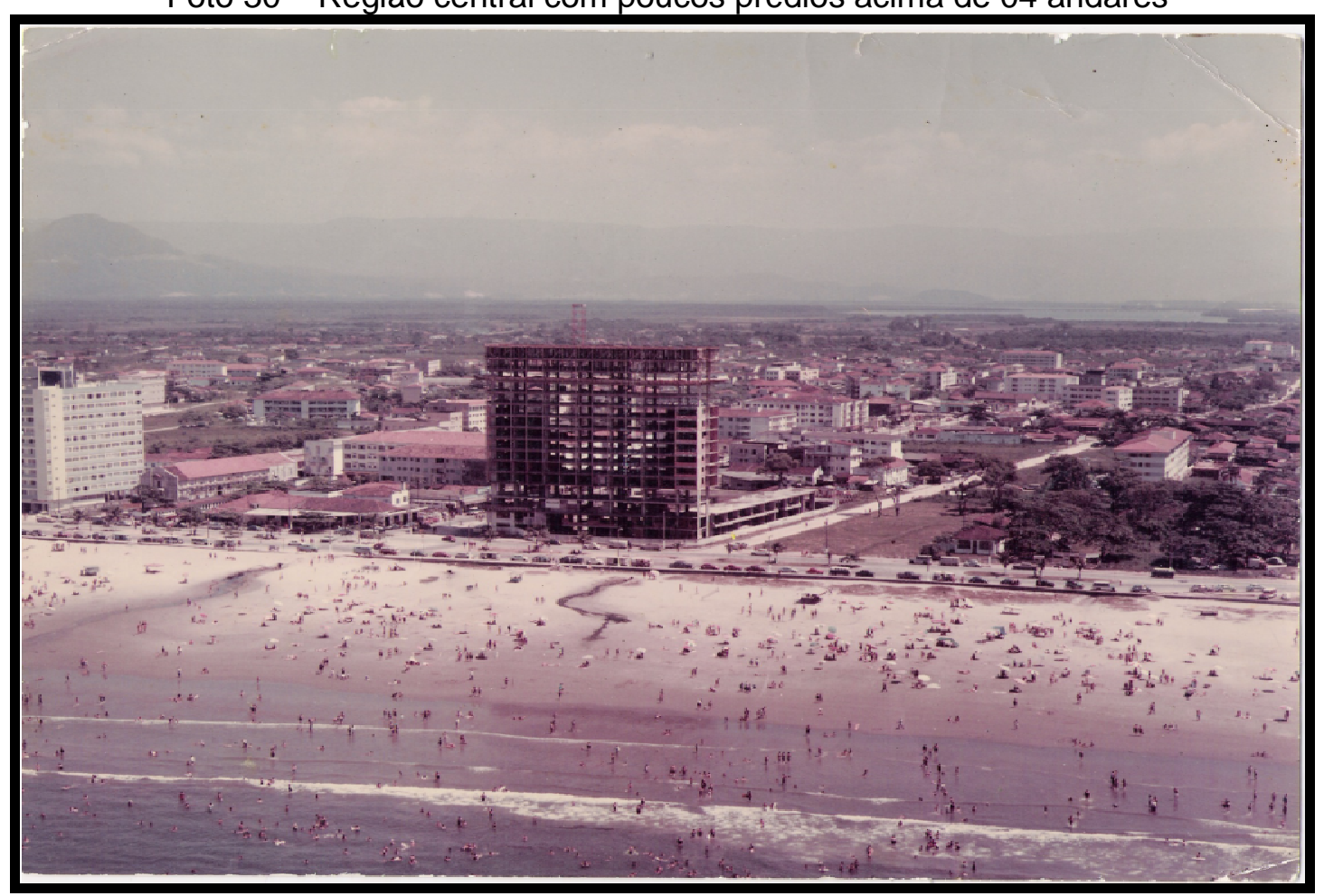

Fonte: Acervo particular de Circe Sanchez Toshi - Autor desconhecido

Nessa foto, vemos o Edifício Maschietto sendo construído e com exceção de um edifício branco de dez andares (no canto esquerdo), vemos que, ao fundo, os prédios ainda seguem o padrão estabelecido pela Lei de Uso e Ordenamento do Solo de décadas passadas, que limitava a altura dos edifícios a quatro andares.

Na década de 1980, temos ainda a entrega das duas pistas da Ponte do Mar Pequeno em dezembro de 1981 e março de 1982, a qual Barreiros (2002, p. 11) informa que:

“(..) o seu desenvolvimento [o de Praia Grande] (...) apresentou uma grande aceleração a partir da construção da Ponte do Mar Pequeno. De uma forma geral toda a baixada será beneficiada, interligando-se mais fortemente com a Região Metropolitana de São Paulo" (Barreiros, 2002, p. 11).

Em relação à Rodovia dos Imigrantes, ele diz, ainda, que:

"A conclusão das obras da Rodovia dos Imigrantes permitirá uma significativa melhoria da acessibilidade da Região Metropolitana da 
Baixada Santista e isso se refletirá em vários aspectos. Umas das conseqüências advindas será o menor tempo de viagem. Hoje medimos distâncias muito mais pelo tempo despreendido no deslocamento do que pela distância espacial, de forma que a baixada ficará 'mais perto' do Planalto" (Barreiros, 2002, p. 11).

Dessa forma, quando Barreiros (2002) faz menção à melhoria da acessibilidade do Planalto com à Região Metropolitanda da Baixada Santista (RMBS), devido à entrega da nova pista da Imigrantes, Praia Grande, nos dias atuais, sai como grande beneficiária. Nesse sentido, esta nova pista, a Rodovia dos Imigrantes, desemboca quase que diretamente na região central da cidade de Praia Grande. Assim, esse novo objeto técnico traz consigo uma diminuição do tempo de viagem, encurtando, não só a distância, mas também, o tempo que separa essas regiões. Portanto, as melhorias nos meios de circulação foram decisivas para a retirada de Praia Grande do parcial isolamento que sofreu por tanto tempo. Esses novos meios de comunicação proporcionaram um encurtamento das "distâncias-tempo" permitindo a aglomeração humana da qual menciona Sanchez (1991, p. 230).

Vale ressaltar que o próprio Raffestin (1993, p. 215) nos diz que "passo a passo com a evolução, as distâncias-tempo se encontram, ou seja, as técnicas de circulação melhoram". Assim, esses acréscimos técnicos vão incrementando o fenômeno do turismo de segunda residência na Estância Balneária de Praia Grande, com viagens de curta distância, apoiado fortemente por essa melhoria das técnicas de circulação, pela qualidade das estradas e acessibilidade que encurtam distâncias e nos fazem chegar mais rápidos aos destinos turísticos que queremos chegar.

No entanto, a acessibilidade é algo que merece especial atenção pela administração pública, agentes imobiliários e demais envolvidos no desenvolvimento de um município, em especial, aqueles que são lugares turísticos $^{46}$. Sendo assim, as condições de acessibilidade podem restringir ou

\footnotetext{
${ }^{46}$ Cruz (2003, p. 7) define lugar turístico como sendo "uma expressão utilizada para se referir a lugares que já foram apropriados pela prática social do turismo como também a lugares considerados potencialmente turísticos.
} 
facilitar o consumo massivo do turismo, ou ainda, facilitar ou restringir o desenvolvimento do ramo da construção civil. Ainda, em relação ao deslocamento, Sanchez (1991, p. 240) aponta:

\begin{abstract}
"Um aspecto primordial para o uso do espaço turístico se centra no deslocamento. Neste sentido cabe distinguir entre a procedência da demanda e os meios e canais de transporte e deslocamento. Assim, então, a acessibilidade e o tipo de meio de transporte que possibilita merece uma especial atenção (...). A acessibilidade ao espaço turístico por um, outro ou ambos os meios de transporte, será de grande importância tanto para possibilitar ou restringir um consumo massivo, como para condicionar a funcionalidade de cada área" ${ }^{47}$
\end{abstract}

Desse modo, o deslocamento desempenha um papel importante para o desenvolvimento do turismo e para o ramo da construção civil. Portanto, ele merece uma especial atenção por parte de todos os envolvidos, tanto para os agentes públicos, quanto para os privados.

Por fim, não foram somente a introdução do turismo de segunda residência, a atuação do ramo da construção civil, as melhorias na circulação ou, ainda, a nova forma urbana que trouxeram mudanças decisivas no espaço e no cotidiano dos habitantes e turistas que freqüentam esta estância balneária, e sim, um conjunto de fatores. Portanto, abordaremos no próximo capítulo, algumas especificidades da urbanização e que também devem ser levadas em conta de modo a nos possibilitar um maior entendimento do processo de uso e ocupação do solo, da urbanização e das transformações físicas, econômicas, sociais e políticas dessa cidade-média, localizada no litoral sul do estado de São Paulo.

${ }^{47} \mathrm{O}$ texto em espanhol diz:

"Un aspecto primordial para el uso del espacio turístico se centra en el desplazamiento. En este sentido cabe distinguir entre la procedência de la demanda, y los medios y canales de transporte y desplazamiento. Así, pues, la accessibilidad y el tipo de medio de transporte que possibilita merece una especial atención (...). La accessibidad al espacio turístico por uno, otro, o ambos medios de transporte, será de gran importancia tanto para posibilitar o restringir un consumo masivo, como para condicionar la funcionalidad de cada área". 
CAPÍTULO III - ESPECIFICIDADES DA URBANIZAÇÃO

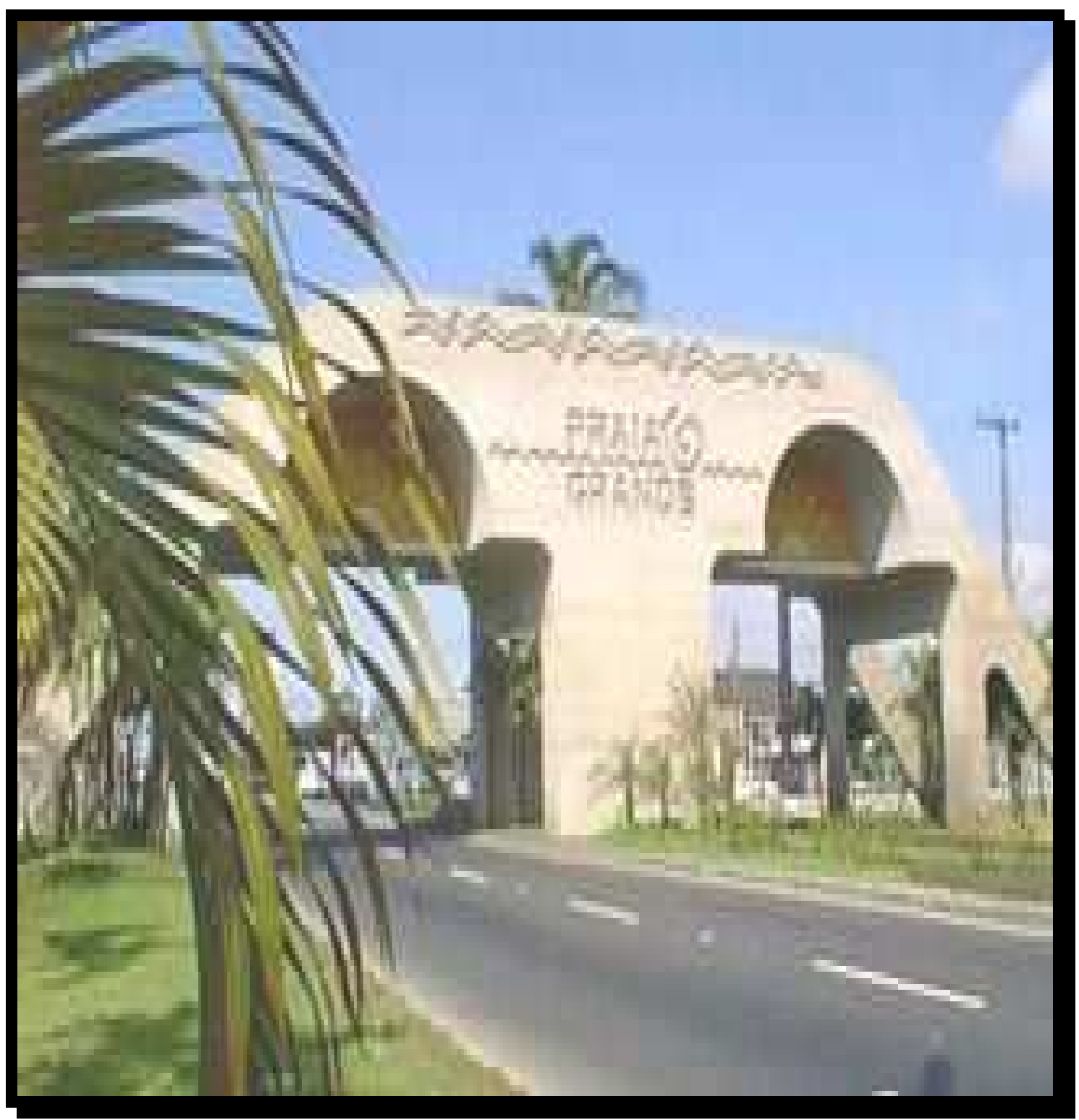


Nesse último capítulo, trataremos de algumas especificidades da urbanização e da segunda residência em Praia Grande. De acordo com o que nos diz Santos (2006, p. 46), "para se entender a urbanização não se pode pensá-la de forma isolada, mas considerando outros aspectos que envolvem a dinâmica econômica e social”. Assim, alguns pontos importantes envolvendo algumas especificidades da Estância Balneária de Praia Grande, tais como: emancipação, expansão urbana, aumento da população, população carente, impactos ambientais, novo tecido urbano, plano diretor, turismo de segunda residência e principais atrativos se fazem necessários para uma maior compreensão do uso e ocupação do solo e do seu processo de urbanização.

\section{1 - Sua emancipação política e a urbanização}

A emancipação política de Praia Grande não aconteceu de repente, comenta Siqueira (2002, p. 11). Os moradores desta região vicentina se viram insatisfeitos com tantos problemas de infra-estrutura, serviços de saneamento básico, abastecimento de água, luz, vias de acesso, problemas na área da saúde e muitos outros. Com esse descontentamento, os moradores do bairro de Solemar viram a possibilidade de se desmembrarem de São Vicente e, assim, conforme registros históricos, em 1953, houve uma primeira tentativa de emancipação, sem sucesso - iniciada por Júlio Secco de Carvalho. Anos depois foi formado um outro grupo em prol da emancipação, mas também sem conseguir o sucesso almejado, conforme relato extraído de uma matéria do jornal A Tribuna (A TRIBUNA, Santos, 19 jan. 1989. Caderno Baixada \& Litoral, s.p.), se afirma:

“(...) A luta resultou da insatisfação popular contra a administração de São Vicente, formando-se uma comissão em prol da emancipação, liderada por Secco de Carvalho e integrada por Nestor Ferreira da Rocha, Heitor Sanches e Israel Grimaldi Milani. Essa comissão, porém, não obteve o êxito esperado.

Mais tarde surge então um outro grupo liderado por Oswaldo Toschi, que também vê seu sonho fracassar. Em 1962, o movimento pela emancipação renasce e desta vez conta com nomes como Paschoalino Borelli, João Bispo dos Santos, Dorivaldo Loria Junior, atual prefeito do Município, Paulo Fefin, Oswaldo Ramacciotti, Israel Grimaldi e Israel Barreto. Essa nova comissão conta com o apoio do deputado estadual Hilário Torloni". 
De acordo com a matéria, esses movimentos em prol da emancipação, se deram devido ao fato de haver grande insatisfação dos moradores da região de Praia Grande em relação à administração de São Vicente. Anos depois, em 1963, foi feito um plebiscito, mas ainda sem conseguir o que a população esperava. A Lei 8.092 de 28/02/1964 é que cria, então, o distrito e a cidade com o nome de Praia Grande, com sede no bairro do Boqueirão. Segundo matéria do jornal $A$ Tribuna (A TRIBUNA, Santos, 19 jan. 1989. Caderno Baixada \& Litoral, s.p.), a emancipação se deu somente em 1967, quando foi nomeado o primeiro interventor para região, o engenheiro Nicolau Paal, conforme o relato abaixo:

“(...) A grande conquista concretizou-se mesmo em 1967, quando no dia 09 de janeiro, o então presidente Castelo Branco nomeou o engenheiro Nicolau Paal, interventor federal de Praia Grande, que assim consagrou-se como Município, instalado oficialmente em 19 de janeiro. Garantida a emancipação, veio a luta pela autonomia. Mas o pleito acabou não ocorrendo, devido ao Ato Complementar no 37, do governo da ditadura militar. Dessa forma, assumiu novo interventor - Paulo Sandoval, em fevereiro de 68".

No entanto, até 28 de fevereiro de 1964, administrativamente, as terras de Praia Grande, ainda pertencia a São Vicente (ver mapa 04). Sendo assim, somente três anos depois, ou seja, em 1967, foi que este balneário veio a se emancipar definitivamente de São Vicente.

A primeira eleição para prefeito de Praia Grande ocorreu somente em 15 de novembro de 1968, com Dorivaldo Loria Junior como seu primeiro prefeito. Desde sua emancipação em 1967, até a data da posse do seu primeiro prefeito, essa estância balneária teve somente interventores. O então eleito chefe do Executivo de Praia Grande, Dorivaldo Loria Junior, também conhecido pelo apelido de "Dozinho", teve em 1ํ de janeiro de 1969, a honra de ser o primeiro prefeito eleito de Praia Grande. Em 1968, também, foi organizada a Câmara Municipal de Praia Grande (A TRIBUNA, Santos, 19 jan. 1989. Caderno Baixada \& Litoral, s.p.). Assim, a partir da década de 1970, já emancipada de São Vicente, registra-se uma grande expansão urbana e um grande aumento da população praiagrandense. 
Mapa 04 - São Vicente antes da emancipação de Praia Grande em 1967

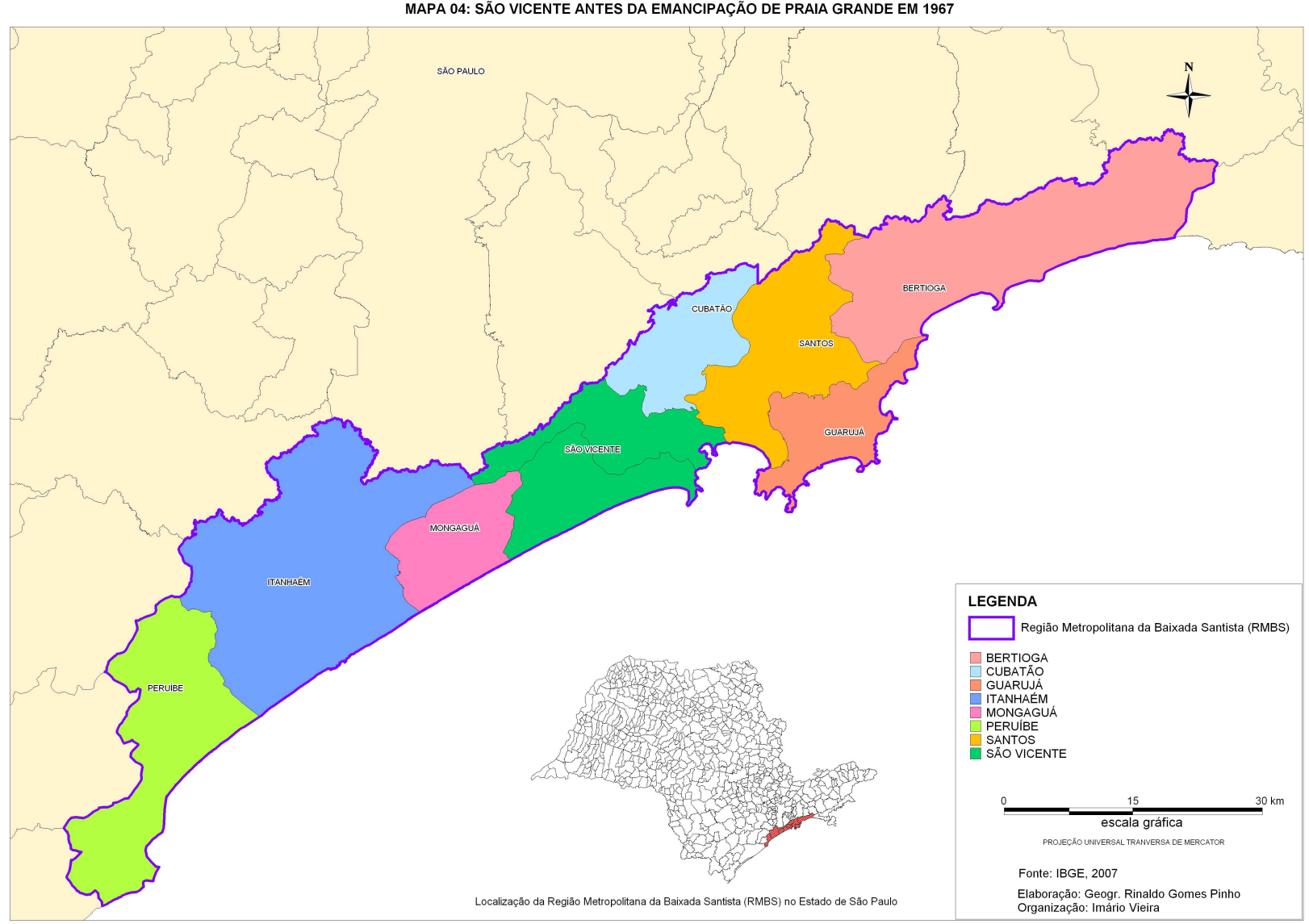

Fonte: IBGE, 2007 - Elaboração Geogr. Rinaldo Gomes Pinho 


\section{2 - Uma grande expansão urbana e o aumento da população}

As transformações ambientais, políticas, econômicas e sociais pelas quais passou o distrito de Praia Grande até sua emancipação e que vem se estendendo até os dias atuais, não afetaram somente o uso e ocupação do solo, mas também a dinâmica de suas relações com as cidades vizinhas e com as regiões metropolitanas do planalto paulista devido ao desenvolvimento de suas economias e dos meios de circulação com essa estância.

Duas décadas antes da emancipação da cidade de São Vicente, ocorre uma grande expansão urbana em Praia Grande. Essa grande expansão urbana, ocorrida a partir da década de 1950, foi facilitada pelo grande incremento ocorrido na economia brasileira a partir "do processo de industrialização" do início do século passado, principalmente na região do $\mathrm{ABCDM}^{48}$. Esse processo de acúmulo de capital levou a população com melhor renda a buscar por lugares de lazer e à aquisição de uma segunda residência provocando um boom no mercado imobiliário. Em relação a isso, em uma matéria do jornal A Tribuna (A TRIBUNA, Santos, 19 jan. 2005. Especial Municípios. 2 p.) encontramos:

\footnotetext{
"Essa ocupação pioneira [da região da Baixada Santista] iria ganhar maiores contornos alguns anos depois com a construção da Via Anchieta e a expansão da indústria automobilística que aceleraram o processo de êxodo semanal do Planalto para a região, provocando a valorização dos terrenos localizados na área da orla marítima. Os primeiros loteamentos criados [em Praia Grande] foram o Jardim Guilhermina e Cidade Ocian".
}

Esta expansão urbana foi grandemente favorecida pela construção da Via Anchieta, pela expansão da indústria automobilística e, sem esquecer, da entrega da Rodovia Padre Manuel da Nóbrega (SP 55 na década de 1960). Nos próximos 30 anos, a partir de 1950, a urbanização teria um enorme crescimento, a sua população urbana aumentaria consideravelmente e, ainda, a sua forma de uso e ocupação do solo também sofreria grandes alterações.

\footnotetext{
${ }^{48}$ Termo usado para definir os municípios de Santo André, São Bernardo do Campo, São Caetano, Diadema e Mauá.
} 
Segundo dados do IBGE, a população de Praia Grande, era representada pelo distrito de Solemar ${ }^{49}$ nos censos de 1950 e 1960 e a partir do censo de 1970, os dados coletados já foram da própria cidade de Praia Grande.

Percebemos pelo tabela abaixo (ver tabela 01), que a população rural reduziu-se ao ponto de não ser mais quantificável pelos órgãos de levantamento, entre as décadas de 1960 e 1970 e houve um grande aumento da população urbana a partir da década de 1960. Entre os anos de 1950 e 1960, a população urbana aumenta de 68 pessoas para 2.867 em 1960 e 19.704 em 1970. De acordo com os dados oficiais do censo do IBGE de 2000, Praia Grande, contava com uma população fixa de 193.582 habitantes e segundo estimativas do SEADE/IBGE, a população aproximada em 2007 é de 248.000 habitantes (Disponível em http://www.seade.gov.br/produtos/perfil/perfil.php, acesso em 21/01/2008, por Imário Vieira).

Tabela 1 - População Rural e Urbana da Estância Balneária de Praia Grande Segundo os Censos do IBGE de 1950-2000

\begin{tabular}{|l|l|l|l|l|l|l|l|}
\hline Censos & 1950 & 1960 & 1970 & 1980 & 1991 & 1996 & 2000 \\
\hline $\begin{array}{l}\text { População Urbana } \\
\text { e suburbana }\end{array}$ & 68 & 2.867 & 19.704 & 66.011 & 123.492 & 150.388 & 193.582 \\
\hline & & & & & & & \\
\hline
\end{tabular}

Fonte: IBGE, Censos Demográficos de 1950, 1960, 1970, 1980, 1991, 1996 e 2000. Elaborado por: Imário Vieira

Como podemos notar, Praia Grande, entre as décadas de 1960 e 1970, tem de acordo com censo do IBGE, um aumento de 16.837 pessoas na sua população urbana.

Assim, também na década de 1950, Praia Grande sofre grande influência devido ao crescimento econômico e industrial dos pólos emissores do turismo de segunda residência para esta estância. Uma dessas regiões de influência é a do $A B C D M$ que, nesta mesma época, passava por um grande surto de crescimentos

\footnotetext{
${ }^{49} \mathrm{O}$ Distrito de Solemar, pertencente a cidade de São Vicente, foi criado para representar a população de São Vicente que habitava a região de Praia Grande.
} 
industrial devido ao Plano de Metas do governo Kubitschek. Em relação a esse crescimento, Camargo (2003, p. 57) assinala que:

\begin{abstract}
"uma nova fase de crescimento industrial e urbano seria observada na região [do $A B C D M]$ em meados dos anos 50, no contexto de redirecionamento da industrialização no país, um dos pontos de honra do chamado Plano de Metas sob o governo de Juscelino Kubitschek".
\end{abstract}

Nesse contexto, Souza (1984, p. 12) comenta que, após a Segunda Guerra Mundial, a região do grande $A B C$ tornou-se o principal celeiro industrial do país. Ainda na mesma página, ela segue dizendo que "capitais estrangeiros fixaram-se em seu território, constituindo grandes unidades industriais". Souza (1984, p. 12) continua assinalando que "enquanto o país de 1940 a 1980 apresentou um crescimento populacional de $289 \%$, a região [ABC] ultrapassou largamente a média nacional, atingindo um crescimento de 1838\%". Esse crescimento econômico pode ter sido um forte propulsor do turismo de segunda residência para a região da Baixada Santista devido ao grande desenvolvimento na região da metrópole de São Paulo e na região do Grande $A B C$ e pela demanda por áreas de lazer aos finais de semana, férias e feriados. Assim, a praia era um grande atrativo para esta população.

Como já mencionado, lembramos que alguns dos motivos que colaboraram para esse incremento da população urbana em Praia Grande, entre a década de 1950 e 1960, pode ter sido a inauguração do Conjunto Habitacional Cidade Ocian (ver foto 31), em maio de 1956, pela Organização Construtora e Incorporadora Andraus Ltda. Esse conjunto habitacional oferecia uma grande quantidade de moradias, o que de certa forma, pode ter beneficiado a fixação de inúmeros trabalhadores da construção civil em Praia Grande. Nessa mesma época, eram muitos os empreendimentos imobiliários que estavam em construção e, além desses, tínhamos ainda, as obras da construção da Rodovia Padre Manuel da Nóbrega (SP-55). Mesmo que esses empreendimentos imobiliários fossem destinados ao turismo de massa, isso não impossibilitava a fixação desses trabalhadores e de outros interessados em fixar residência permanente na região. 
Foto 31 - Vista aérea do Conjunto Habitacional Cidade Ocian em 1955

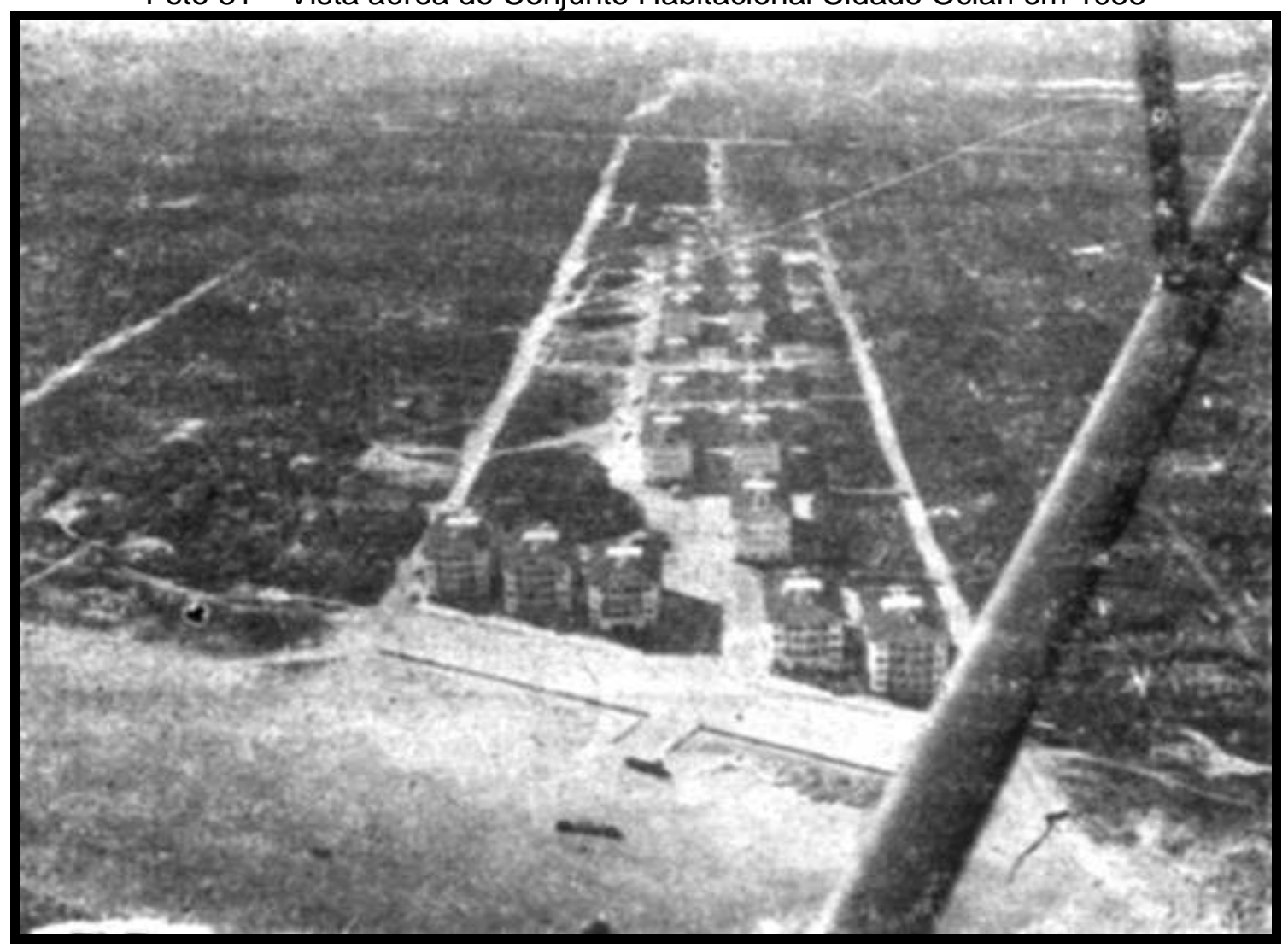

Fonte: Disponível em http: //www.novomilenio.inf.br/pg/pgh020.htm, acesso em 11/01/2007, por Imário Vieira. Autor desconhecido

Essa foto, embora não seja de boa qualidade, mostra o Conjunto Habitacional Cidade Ocian ainda em construção. Como já informado, suas obras foram entregues em 1956 e contavam com a construção de 22 prédios com um total de 1350 apartamentos. No entanto, vemos que ainda na metade do século passado, era possível ver este conjunto habitacional circundado por áreas inabitadas.

Contudo, conforme a "Tabela 1" acima, percebemos, na década de 60, uma grande diminuição da população rural e um aumento da população urbana, já mostrando a passagem da atividade econômica deste distrito de São Vicente, do setor primário para o setor terciário ou de serviços e com um grande surto de loteamentos e construções que agora passavam a ser verticalizadas. Magalhães (1965, p. 71) registra que era grande o surto de loteamentos e do comércio nessa época: 
"Sua própria fisionomia atesta a importância da função comercial. Ali se encontram vários postos de serviços para autos; farmácias; casas de artigos para praia, estas em número reduzido (três no máximo); muitos restaurantes, mercearias, bares e considerável número de depósitos de materiais para construção e agências imobiliárias. Estes dois últimos vêm demonstrar como é grande o surto de construções e loteamentos".

Dessa forma, devido a esse grande surto de loteamentos e construções, do qual nos menciona o autor, a indústria da construção civil consolida sua presença no crescimento urbano da região dessa estância balneária. Assim, o espaço passa a reproduzir-se cada vez mais em função das estratégias imobiliárias.

Outros fatores importantes para o incremento da população de Praia Grande devem ser levados em conta, tais como: após a Segunda Guerra Mundial, houve um grande fluxo de imigrantes para a região da Baixada Santista, a entrega da Via Anchieta em $1947^{50}$ (pista ascendente em março de 1947 e pista descendente em julho de 1953) e a consolidação de Cubatão como Pólo Industrial (petroquímico e siderúrgico) a partir da segunda metade da década de 50 . Nessa época, a Baixada Santista, passou a receber um grande contingente populacional. Sobre o impacto da construção da Via Anchieta, em uma matéria do jornal $A$ Tribuna (A TRIBUNA, Santos, 19 jan. 2005. Especial Municípios. 2 p.), encontramos:

"Com a construção da Via Anchieta, porém, deu-se a abertura do mercado turístico já que a expansão da indústria automobilística possibilitou o êxodo semanal do Planalto à região, valorizando as terras da orla da praia em toda a Baixada Santista".

Desta forma, acreditamos que o desenvolvimento dos meios de circulação, como a construção da Via Anchieta, aliado à expansão da indústria

\footnotetext{
${ }^{50}$ De acordo com Barreiros (2002, p. 8), a Via Anchieta teve várias interrupções em sua construção desde quando se deu início a mesma em 1929. A primeira interrupção foi com a crise capitalista de 1929, interrompendo as tentativas de financiamento, cancelando os contratos de sua construção na época. A retomada das obras ocorre somente em 1939, mas, após o início da Segunda Guerra Mundial, o andamento das obras é novamente prejudicado. Só em 1947 que a primeira pista é finalmente entregue, ou seja, 18 anos após o início das primeiras obras.
} 
automobilística, favoreceu grandemente o turismo da região da Baixada Santista, além de ter valorizado consideravelmente as terras nas regiões próximas à orla das praias. A própria Via Anchieta também deve ter favorecido a fixação de moradores na região devido à melhoria nos meios de circulação entre o litoral e o planalto.

Nesse sentido, Barreiros (2002, p. 8) também nos dá sua contribuição sobre a importância do eixo de ligação da Via Anchieta, e que segundo o autor:

\begin{abstract}
“(..) transformou o planalto paulista em um grande pólo industrial, o ABCD - Santo André, São Bernardo, São Caetano, Diadema, além da própria cidade de São Paulo. A acessibilidade promovida pela Via Anchieta faz com que haja uma grande integração entre os pólos industriais do planalto com o pólo petroquímico e siderúrgico de Cubatão e com o maior porto do Brasil. Essa sinergia potencializa o desenvolvimento econômico destas localidades".
\end{abstract}

Notamos, assim, a participação da Via Anchieta na metade do século passado para o crescimento não só populacional, mas também econômico da hoje Região Metropolitana da Baixada Santista (RMBS), trazendo o desenvolvimento e capital para as regiões litorâneas.

No entanto, conforme "Tabela 1" elaborada com base no censo do IBGE, nas décadas de 1970 e 1980, houve ainda um grande salto da população existente, provavelmente devido a um maior número de empreendimentos imobiliários que se deu nessa cidade-média paulista e que foi favorecido pela lei que instaurou o sistema brasileiro de habitação, dinamizando a construção civil e a exploração imobiliária.

Verificamos que, até 1972, a maior parte da expansão urbana, registrada em Praia Grande, concentrou-se na região de ocupação mais antiga e mais próxima ao seu sítio urbano. Foi a partir do Censo do IBGE de 1996 que foi constatada uma grande expansão urbana, principalmente, no lado direito da SP55 , onde se concentra a população mais carente da cidade. Nesse mesmo ano, a expansão urbana configurou-se da seguinte forma: no lado esquerdo da SP-55 (nas áreas mais próximas à sua orla) teve sua maior concentração nas regiões localizadas entre os bairros Mirim e Flórida, porém, nas regiões que ficam ao lado 
direito da SP-55 (nas áreas mais distante da orla), essa expansão urbana localizou-se nas regiões que vão desde o terminal Tude Bastos até o bairro Melvi. Após os levantamentos realizados no ano de 2002 pela prefeitura de Praia Grande, verificamos que, do lado esquerdo da SP-55, só foram registrados dois pontos de expansão urbana: um no limite da cidade de Praia Grande com Mongaguá (próximo à sua orla marítima) no bairro Solemar, e outro ponto no Sítio do Campo, fora estas duas regiões, todas as demais áreas de expansão urbana registradas em 2002, localizaram-se do lado direito da SP-55, ou seja, nas regiões mais distantes da sua orla (ver Mapa 05).

Assim, a partir da década de 1990, as obras de embelezamento, melhoramentos da infra-estrutura urbana e medidas promovidas pelas sucessivas gestões municipais, em que, o atual prefeito Alberto Pereira Mourão, fez parte, visaram consolidar a cidade como um importante centro balneário. A partir de então, a Estância Balneária de Praia Grande passou por um grande processo de reurbanização de sua orla e adjacências, com a padronização de quiosques, construção de praças, implantação de ciclovias, plantação de milhares de coqueiros ao longo de seus $22,5 \mathrm{~km}$ de orla entre outras. Desse modo, a partir destas melhorias urbanas e com o processo de verticalização ampliando a oferta de imóveis e, conseqüentemente, aumentando a demanda por segundas residências por parte dos moradores das regiões metropolitanas do estado de São Paulo, a cidade registra um segundo boom de crescimento entre a década de 1980 e 1990. Esse boom, não se dá somente pelo aumento da população (ver tabela 1), mas também pelo aumento das segundas residências, representando mais que o dobro das residências permanentes de Praia Grande (ver tabela 2).

Acreditamos que o crescimento do número de residentes permanentes e ocasionais se deu devido a sua proximidade e a um rápido e eficiente sistema de comunicação com a metrópole de São Paulo e adjacências, firmando a viabilidade e retornos financeiros do processo de exploração imobiliária. Tivemos também, a valorização desses imóveis como forma de investimento motivado pelo turismo de segunda residência, impostos por uma necessidade cada vez mais crescente de circulação e de lazer por parte dos moradores da Região Metropolitana de São Paulo (RMSP), aglomerados e micro-regiões de nosso estado. 
Mapa 05 - Expansão Urbana

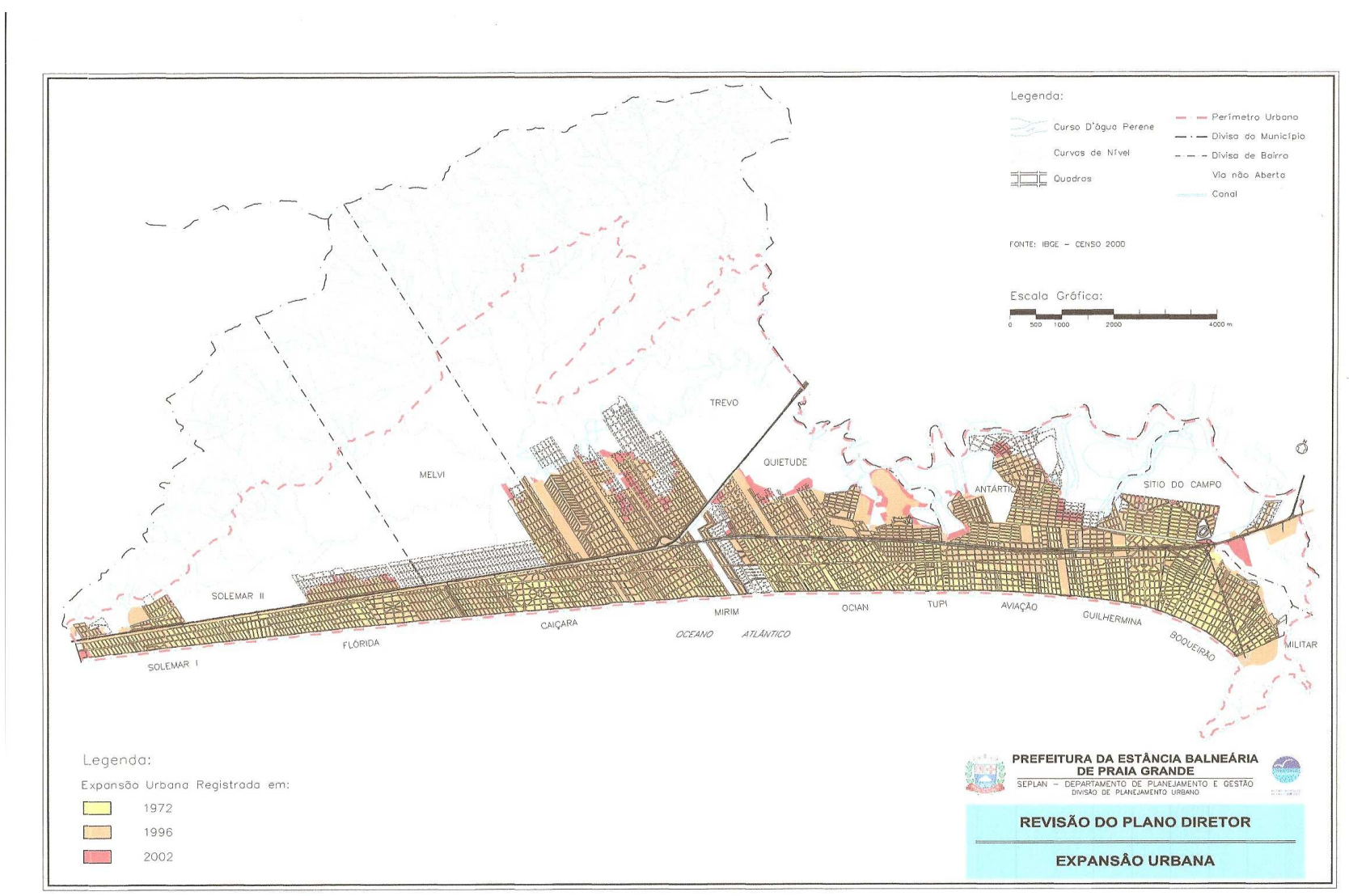

Fonte: Prefeitura da Estância de Praia Grande , SP 
Retomando o que estava na Tabela 1, mencionada anteriormente, vemos que residiam em Praia Grande no ano de 1991, 123.492 habitantes. No entanto, de acordo com a Tabela 2 (Domicílios Urbanos Recenseados por Espécie e Condição de Ocupação) logo acima, Praia Grande, neste mesmo ano de 1991, contava com um total de domicílios permanentes e de usos ocasionais de 102.154 residências, o que significa dizer que, deste total, 32.805 eram domicílios de uso permanente $^{51}$ e 69.354 eram de uso ocasional ${ }^{52}$ ou temporários. Já no último censo feito pelo IBGE em 2000, a Estância Balneária de Praia Grande contava com uma população de 193.582 habitantes e um total de domicílios de 148.305 residências, sendo, 55.030 de uso permanente e 93.275 de uso ocasional. O quadro abaixo nos mostra o número de moradias de uso ocasional ou segunda residência em Praia Grande nos Censos de 1991 e 2000.

Tabela 2 - Estância Balneária de Praia Grande - Domicílios Urbanos Recenseados por Espécie e Condição de Ocupação, Segundo os Censos do IBGE de 1991 e 2000

\begin{tabular}{|c|c|c|c|c|c|}
\hline \multicolumn{5}{|c|}{ Domicílios Particulares de Praia Grande em números absolutos } \\
\hline Censo & Permanente & Ocasional & Fechados & Vagos & Coletivos \\
\hline $\mathbf{1 9 9 1}$ & 32.805 & 69.354 & 17 & 7.423 & 117 \\
\hline $\mathbf{2 0 0 0}$ & 55.030 & 93.275 & 207 & 11.728 & 156 \\
\hline
\end{tabular}

Fonte: IBGE, dados finais dos Censos Demográficos de 1991 e 2000. Elaborado por: Imário Vieira

De acordo com estudos realizados pela SEPLAN - Secretaria de planejamento urbano da cidade de Praia Grande e com base no Censo do IBGE do ano 2000, a maior concentração de residências de uso ocasional ou secundário nessa estância balneária está localizada nas áreas do lado esquerdo da SP-55

\footnotetext{
${ }^{51}$ Conforme conceituado pelo IBGE no Manual do Recenseador do Censo de 2000, domicilio de uso permanente é aquele que foi construído para servir exclusivamente à habitação e, na data de referência, tinha a finalidade de servir de moradia a uma ou mais pessoas.

52 Para o IBGE (Manual do Recenseador do Censo de 2000), domicílio de uso ocasional tem a seguinte definição: é definido quando, na data da referência, o domicílio particular permanente servia ocasionalmente de moradia, ou seja, era domicílio usado para de fins de semana, férias ou outros fins, mesmo que, na data de referência, seus ocupantes ocasionais estivessem presentes.
} 
(sentido Mongaguá), onde 61 a $80 \%$ das residências de uso ocasional registradas estão aí localizadas. Já do lado direito da SP-55, com exceção dos bairros de Solemar I e Florida onde tem um percentual de 41 a $60 \%$, todas as demais áreas, tem representatividade abaixo de 40\% (ver mapa 06).

Nos dias atuais, segundo dados obtidos na prefeitura da cidade, na alta estação, a população dessa estância balneária pode variar de 300.000 até aproximadamente 1.500 .000 de pessoas durante feriados, temporada de férias e finais de semana. Sua densidade demográfica é de $1.335 \mathrm{hab} / \mathrm{Km}^{2}$. No entanto, de acordo com dados pesquisados pelo SEADE/IBGE, no ano de 2005, a densidade demográfica era de $1.601 \mathrm{hab} / \mathrm{Km}^{2}$. Nesta mesma pesquisa do SEADE/IBGE, a participação dos vínculos empregatícios em Praia Grande tinha a seguinte participação em relação à população economicamente ativa: na agropecuária era de 0,07\%; na indústria, 5,38\%; na construção civil, 7,60\%; no comércio, 28,92\%; e serviços, 58,03\%.

Como se pode verificar, a expansão urbana vai se desenvolvendo em Praia Grande com um número cada vez maior de residências secundárias e um conseqüente aumento dos vínculos empregatícios no comércio e serviços de modo a acomodar o grande número de turistas que se dirigem às suas praias em busca do lazer balneário. Outro ponto que nos chamou atenção nesse estudo elaborado pelo SEADE/IBGE foi o fato de que eles conseguiram quantificar, mesmo que ainda de forma insignificante, uma população rural.

Segundo a última pesquisa feita pela EMPLASA, em 2001, a Praia grande contava com 1.460 leitos distribuídos entre os hotéis, flats, pensões e pousadas da cidade, excluindo, desse total, o número de leitos dos motéis e colônias de férias da região. Ainda, de acordo com "Santos e Região Convention \& Visitors Bureau" 53 , Praia grande possui o maior complexo de Colônias de Férias da América Latina. São mais de dez mil leitos com infra-estrutura hoteleira contando com piscinas, auditórios, quadras poliesportivas, restaurantes e salões de jogos.

Portanto, por meio dos números mostrados acima, conclui-se que a prática social do turismo, no Balneário de Praia Grande, está apoiada fortemente nas

53 Disponível em: http://www.santoscidade.com.br/praiagrande.php?pg=tur. Acesso em 21/01/2008, por Imário Vieira. 
moradias de segunda residência, dinamizando seu crescimento urbano e econômico, principalmente após a despoluição das praias e mudanças paisagísticas ocorridas a partir do início da década de 1990.

Na verdade, os projetos surgidos nessa época (a partir da década de 1990), além da recuperação de ruas, valetas de drenagem, recuperação de áreas alagadiças, construção de praças, monumentos turísticos, centros de convivências e tantas outras melhorias de infra-estrutura, visaram dar um tratamento paisagístico à Praia Grande. Nessa mesma época, também buscou-se solucionar problemas viários, de mobilidade e problemas de saneamento básico nas regiões mais ao oeste desta estância e nas regiões centrais.

Praia Grande, nos dias atuais, não somente atrai turistas pelas suas belas praias repletas de coqueiros, ciclovias, Avenida Beiramar totalmente pavimentada e que liga seus $22,5 \mathrm{~km}$ de litoral de costa a costa, mas também conta com muitos outros benefícios que são oferecidos aos seus turistas. Verifica-se que entre os novos atrativos, temos a reurbanização do principal centro comercial da cidade que foi transformado e melhorado nessa última urbanização da Avenida Costa e Silva e imediações. Essa avenida é uma das principais do centro da cidade e a partir da segunda metade do ano de 2006, recebeu cobertura sobre os calçadões em grande parte de sua extensão e transformou-se em um importante centro comercial e gastronômico, com ruas adaptadas para deficientes, repleto de lojas de comércio dos mais variados gêneros e barzinhos que atraem um público jovem cada vez mais numeroso.

Cabe-se ressaltar que, contemplamos pelo registro fotográfico, este processo de reurbanização recente pelo qual passou o centro comercial da cidade, especificamente a Avenida Costa e Silva (ver fotos 32, 33, 34 e 35). Estas fotos mostram algumas mudanças na paisagem por conta da colocação de cobertura em grande parte do calçadão dessa avenida, a qual favorece o comércio e a transforma em um grande Shopping ao ar livre. Tiramos fotos que mostram a colocação de lajotas e alargamento das calcadas, substituição do pavimento asfáltico por tijolinhos vermelhos, troca de coqueiros por palmeiras imperiais em alguns trechos, construção de fonte e algumas mudanças nas adjacências dessa avenida junto à orla. 
Mapa 06 - Domicílio de Uso Ocasional

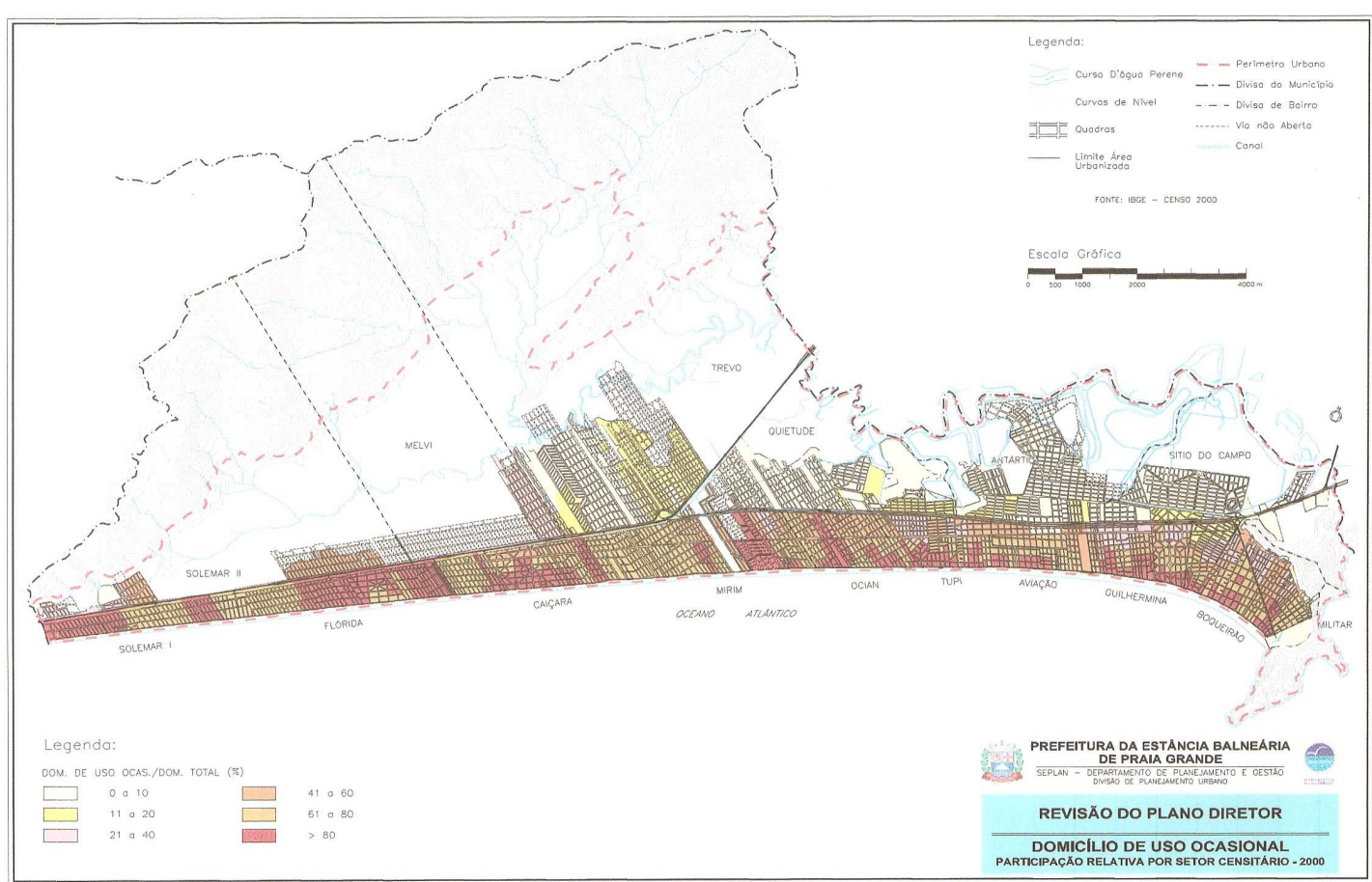

Fonte: Prefeitura da Estância de Praia Grande , SP 
Ressaltamos que estas obras de reurbanização dessa importante avenida de Praia Grande foram concluídas em fevereiro de 2007. Dessa forma, para a população fixa das quadras próximas a essas obras, inclui-se como reflexo direto, a valorização de seus imóveis pela modernização instaurada neste importante

centro comercial da cidade.

Foto 32 - Reurbanização da Interligação da Avenida Beiramar (Avenida Presidente Castelo Branco) com a Avenida Costa e Silva

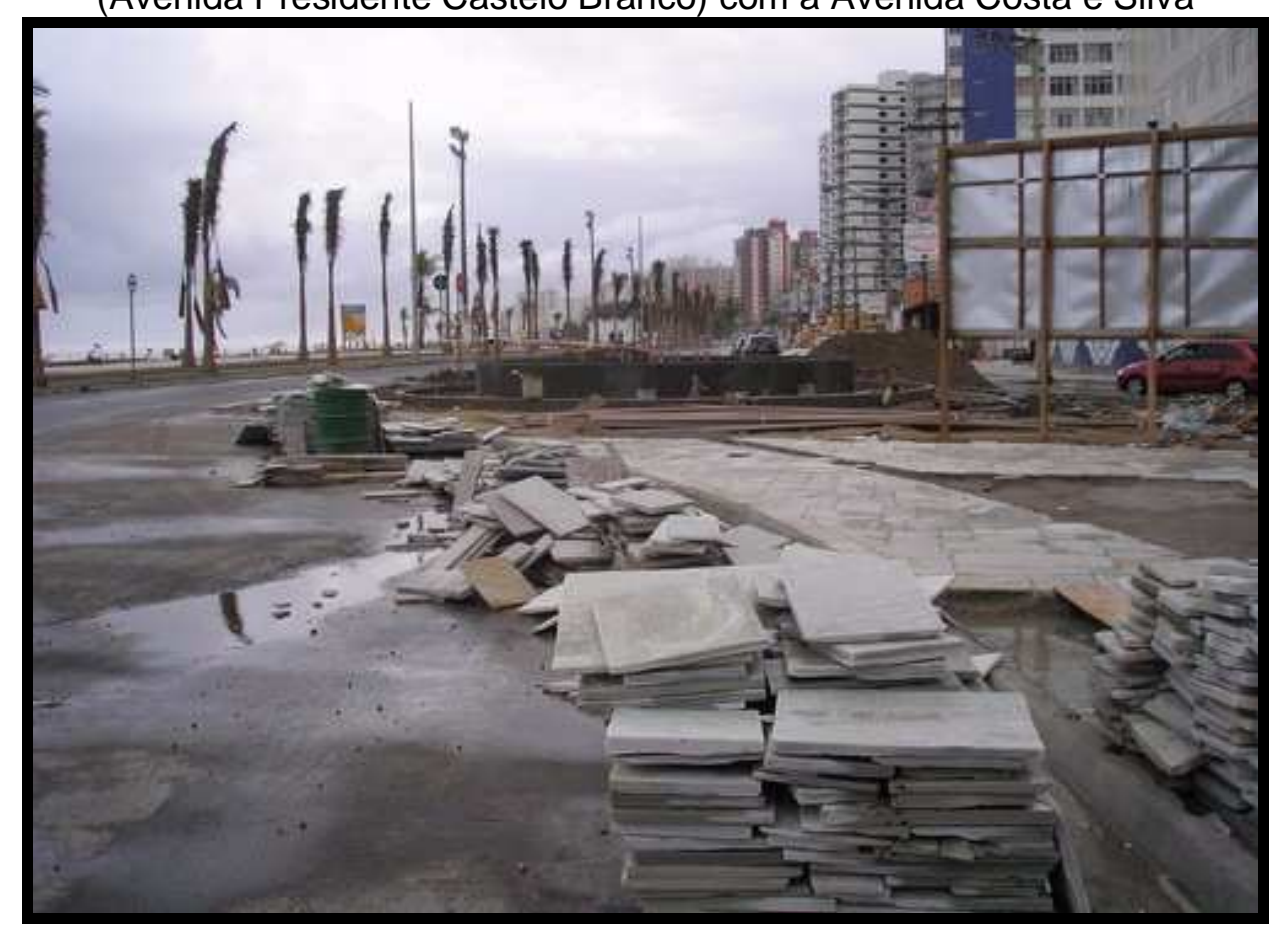

Fonte: Imário Vieira - Data:12/11/2006 - Autor: Imário Vieira

No canto superior esquerdo temos as palmeiras imperiais que substituíram em uma parte da orla os antigos coqueiros plantados na década de 1990. Ao centro, a construção de uma fonte (que dá de frente para a entrada da Avenida Costa e Silva) e no canto inferior direito, o calçadão foi prolongado indo ao encontro da fonte e com a colocação de lajotas. 
Foto 33 - Reurbanização da Avenida Costa e Silva

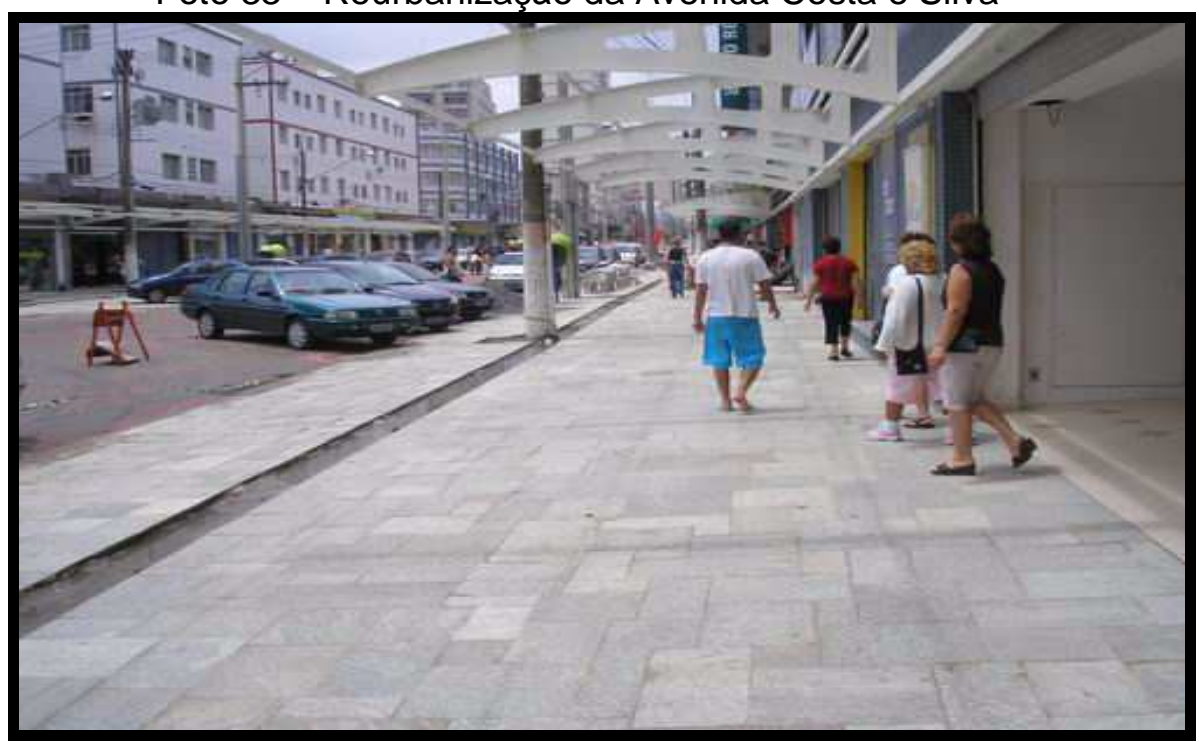

Fonte: Imário Vieira - Data:12/11/2006 - Autor: Imário Vieira

O calçadão da Avenida Costa e Silva foi alargado e colocaram lajotas para dar um aspecto mais bonito e moderno a região central de modo a acomodar o grande fluxo de turistas que lotam a mesma durante os finais de semana e feriados em busca dos restaurantes e comércio ali estabelecidos. Foi colocada, em quase toda a extensão da Costa e Silva, uma cobertura dos dois lados desta avenida que a transformará em um Grande Shopping ao ar livre.

Foto 34 - Reurbanização da Avenida Costa e Silva

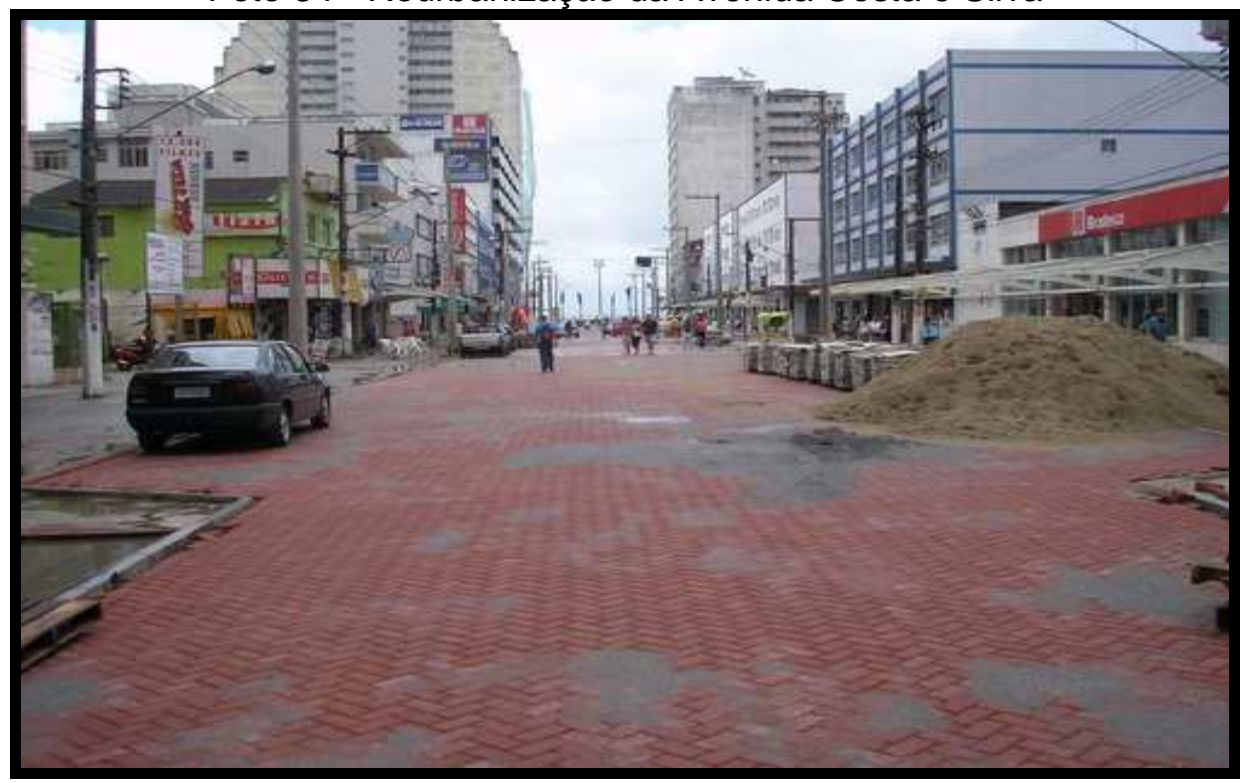

Fonte: Imário Vieira - Data:12/11/2006 - Autor: Imário Vieira 
Nessa época, estava sendo trocada a cobertura asfáltica por estes tijolinhos vermelhos como parte da modernização dessa importante área comercial da Estância Balneária de Praia Grande.

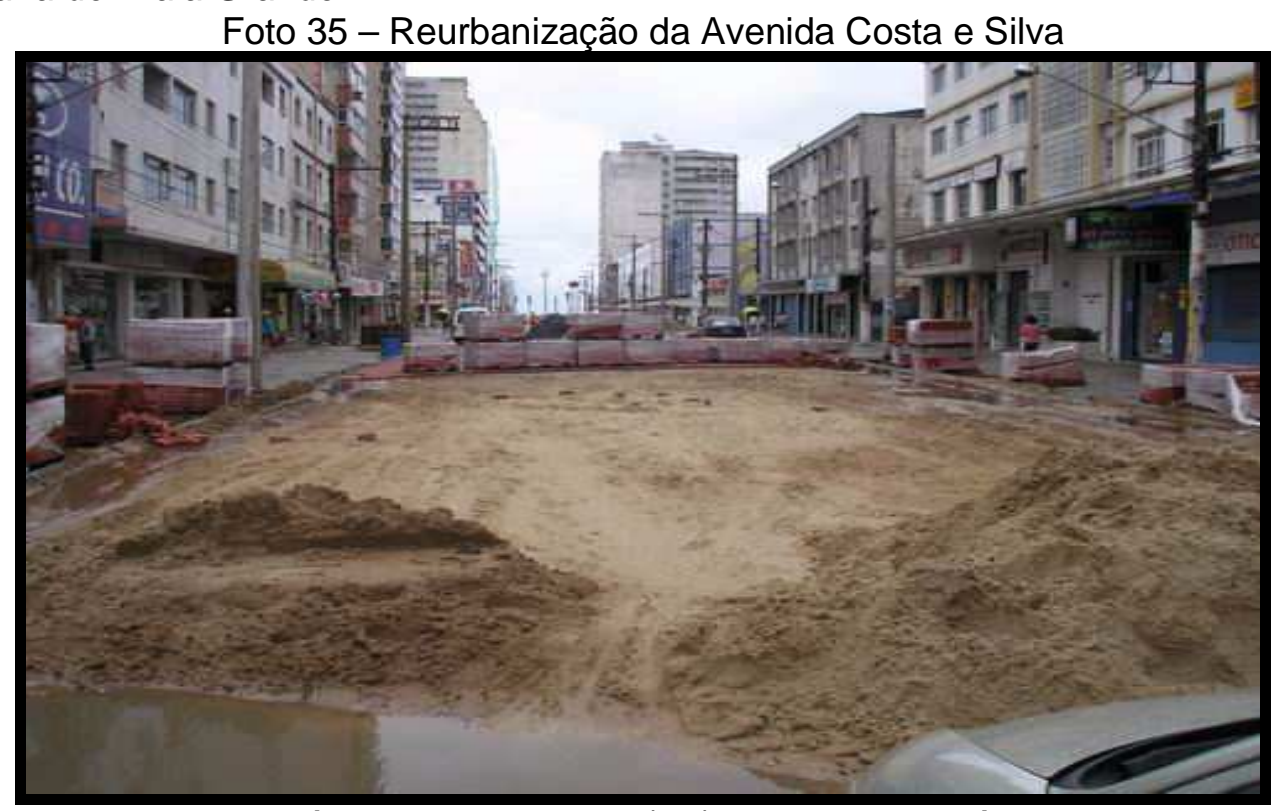

Fonte: Imário Vieira - Data:12/11/2006 - Autor: Imário Vieira

Nessa foto, temos um trecho da Avenida Costa e Silva onde as obras de modernização ainda estavam em um estágio inicial.

Praia Grande segue investindo em melhorais de sua infra-estrutura. Em Janeiro de 2008, foi inaugurado o Espaço Conviver - Boqueirão (ver foto 36) e está previsto, para o primeiro semestre de 2008, a inauguração e o funcionamento do Centro de Informações Turísticas Metropolitanas (CITM) de Praia Grande ${ }^{54}$ (ver foto 37). Estes dois empreendimentos estão localizados na Avenida Presidente Castelo Branco, próximos à Avenida Costa e Silva, onde antes, localizava-se uma unidade do Corpo de Bombeiros. Essa unidade contava com um heliporto, o qual abrigava um helicóptero que fazia o patrulhamento das praias e, diferente do Posto de Informação Turística (PIT) do Bairro Vila Mirim, que presta informações

${ }^{54}$ Este Centro de Informações Turísticas Metropolitanas (CITM) contará com materiais sobre os atrativos turísticos de todos os nove municípios da RMBS, contará com a exposição de produtos regionais, além de mapas de localização e materiais sobre o comércio da região. Este projeto (o CITM) visa incrementar o turismo na região praiagrandense. Trata-se de uma parceira entre Santos e Região, Convention \& Visitors Bureau, Agência Metropolitana da Baixada Santista (AGEM) e os nove integrantes da RMBS. É um projeto inovador no país e necessário para o desenvolvimento do turismo na região, pois o turista não ficará preso a um só lugar. 
sobre o turismo em Praia Grande, esse centro de informações turísticas prestará informações dos nove integrantes da RMBS.

Foto 36 - Espaço Conviver - Boqueirão

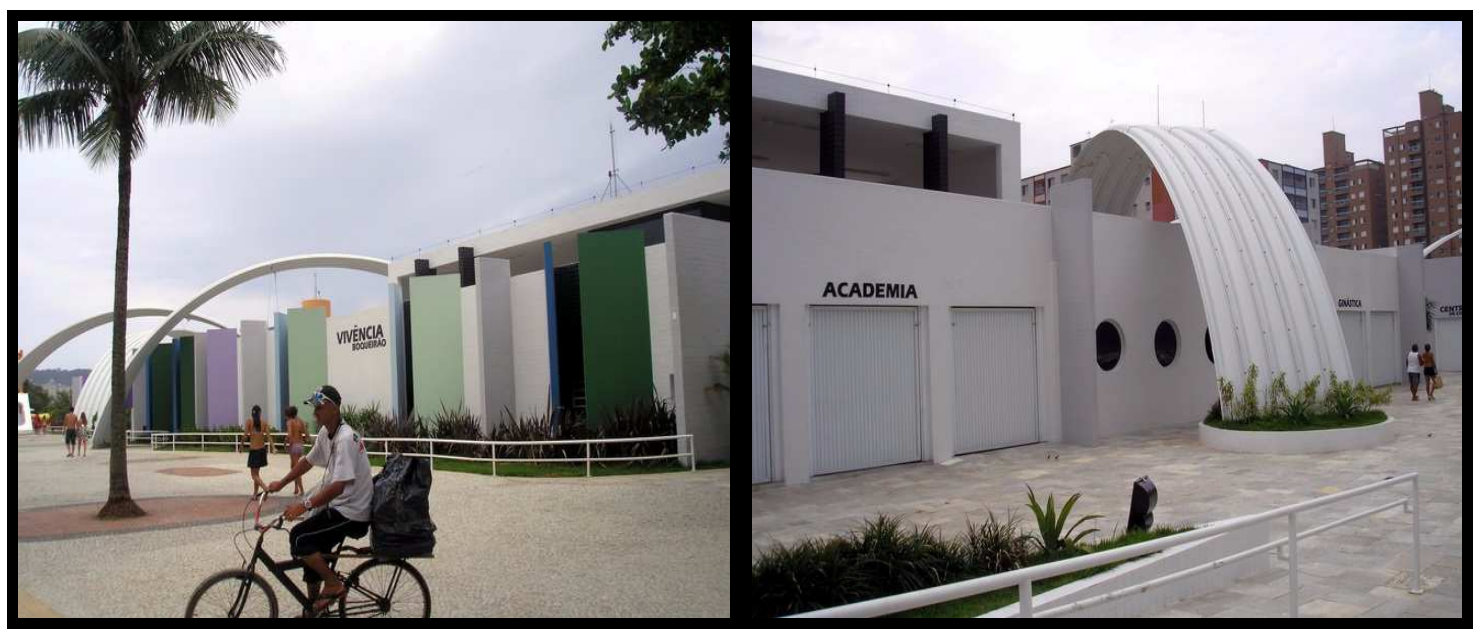

Fonte: Imário Vieira - Data: 26/01/2008 - Autor: Imário Vieira

A instalação destes centros de informações em todos os integrantes da RMBS incentivará a circulação dos turistas e a visita aos pontos turísticos de toda a região. Será mais um elo de ligação entre os integrantes da Região Metropolitana da Baixada Santista.

Foto 37 - Centro de Informações Turísticas (CITM) de Praia Grande, SP

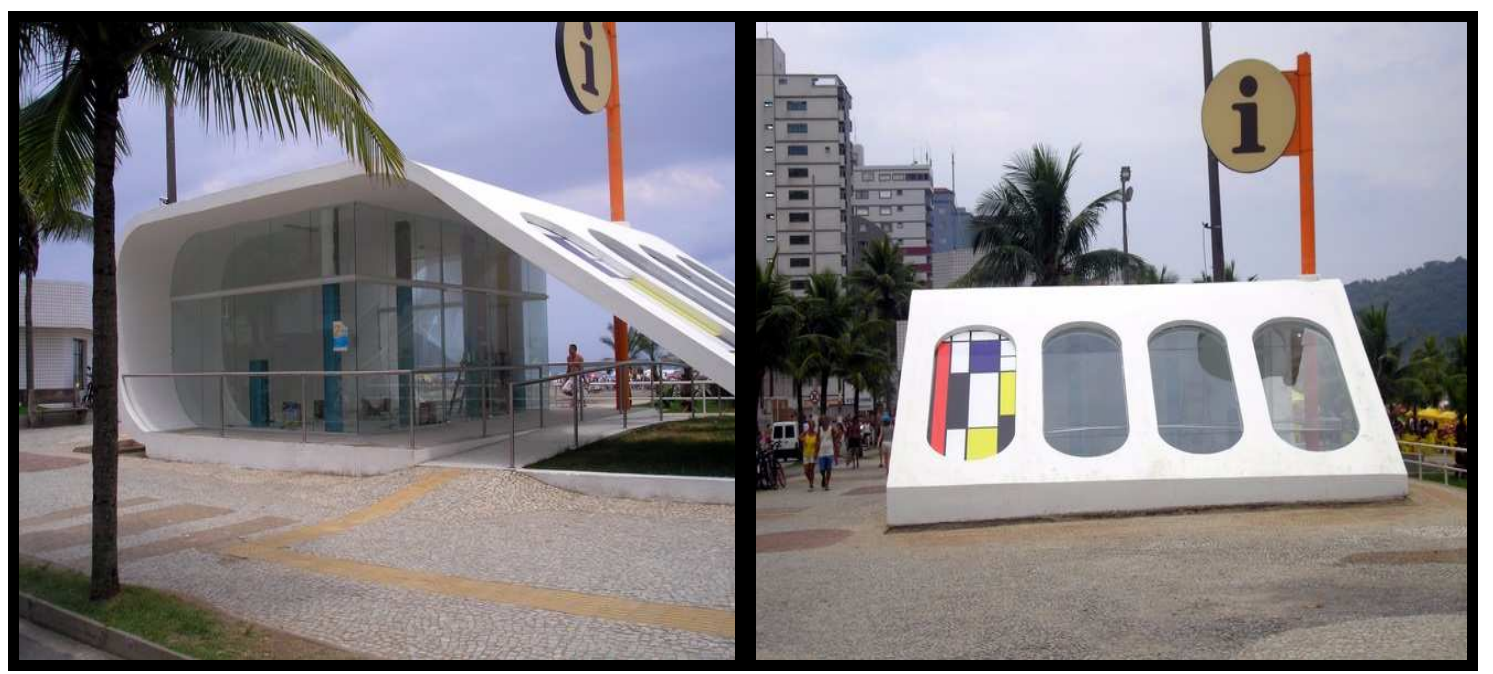

Fonte: Imário Vieira - Data: 26/01/2008 - Autor: Imário Vieira

Esse Centro de Informações Turísticas de Praia Grande foi concebido com um design moderno, sua construção, por si só, já chama a atenção das pessoas que passam pela orla. Ele está localizado ao lado do Espaço Conviver no Bairro Boqueirão e assim que for colocado em uso, deverá servir de grande apoio à atividade turística de Praia Grande. 
Um outro fato importante para crescimento urbano de Praia Grande, segundo informações do diretor regional da SECOVI ${ }^{55}$, Augusto Nini de Oliveria, foi a chegada de gigantes da construção, tais como: Tecnisa, Rossi, Fernandez Mera e Abyara, que vão aquecer o mercado imobiliário da região e que poderão beneficiar os cerca de 120 pequenos e médios construtores locais (PRAIA Grande. A Tribuna, Santos, 19 jan. 2008. Especial. 8 p.).

Assim, a partir do início do século XXI, com esse novo processo de urbanização da orla de Praia Grande, passam a ser incorporados à paisagem local, prédios com mais de 20 andares, enfatizando ainda mais a passagem do espaço produzido como valor de uso para um espaço que se reproduz como valor de troca. Bons exemplos dessa nova fase pela qual está passando esta estância balneária são: o Edifício Pégasus, com 23 andares e o Edifício Residencial Copacabana, com 24 andares (veja foto 38). Contudo, outros prédios com mais de 20 andares estão em construção, como é o caso do condomínio "A Ilha", no Boqueirão, com duas torres de 30 andares e com previsão de entrega para 30 de junho de 2009, e o "Costa do Sol”, na Vila Mirim, com uma torre de 35 andares e com previsão de entrega para 31 de outubro de 2010. Esses empreendimentos imobiliários marcam uma nova fase de condomínios de edifícios com verdadeiros clubes em seu interior, com clube para adultos, kids club, várias piscinas, quadra de futebol gramada, pizza lounge, brinquedoteca, sala de cinema, espaço teen, fitness center, Spa e muitos outros atrativos.

Contudo, se formos comparar os prédios de 3 e 4 pavimentos da primeira metade do século passado com os construídos atualmente em altura, luxo, atrativos e tantos outros benefícios, a diferença é gritante em todos os aspectos, deixando os primeiros muito atrás nos quesitos apresentados.

Numa visão geral, essa estância balneária por meio de suas autoridades competentes, tem procurado ao longo destas últimas duas décadas, estabelecer medidas que facilitem o seu desenvolvimento turístico para o seu dito uso, e conforme Sanchez (1991, p. 223), "pudesse [assim] fazer-se efetivo".

\footnotetext{
${ }^{55}$ SECOVI - Sindicato das Empresas de Compra, Venda, Locação e Administração de Imóveis Residenciais e Comerciais de São Paulo.
} 
Outras medidas tomadas, pela administração atual, tem sido contínuas melhorias nos serviços públicos oferecidos, tais como: políticas de transporte, de segurança, econômica, de infra-estrutura, culturais, sociais e outras.

Foto 38 - Prédios Residencial Copacabana e Pégasus com mais de 20 andares

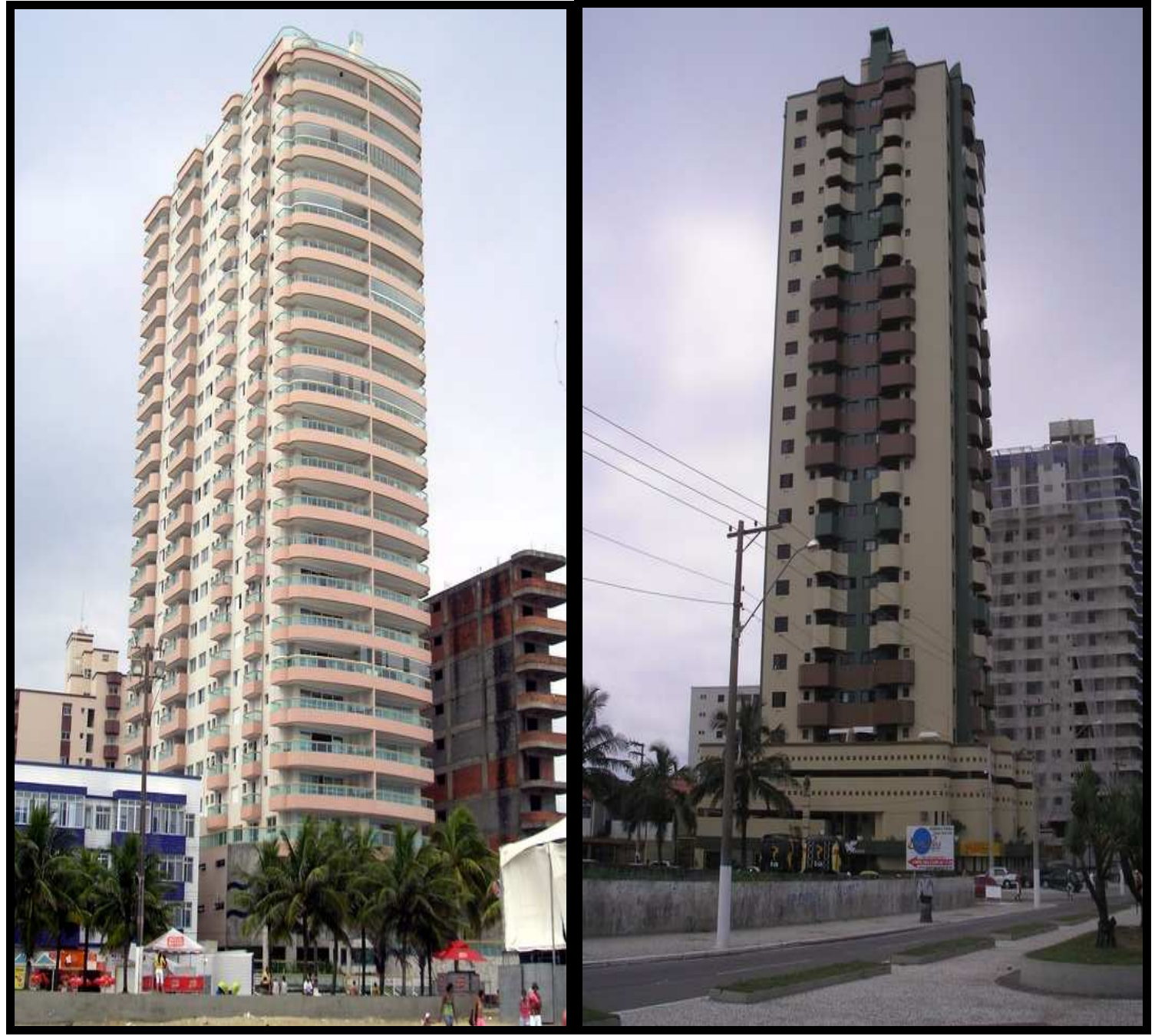

Fonte: Imário Vieira - Data: 12/01/2008 - Autor: Imário Vieira

Essas duas torres estão localizadas, uma de cada lado do Campo da Aviação, em Praia Grande na Avenida Beiramar (Avenida Presidente Castelo Branco) onde despontam estes dois prédios luxuosos com mais de 20 andares.

Contudo, essa grande expansão urbana pela qual tem passado o balneário de Praia Grande em decorrência da exploração do turismo de segunda residência, e abrupto aumento da sua população nas altas temporadas, trazem algumas 
conseqüências ruins tanto para a população permanente quanto para a população ocasional da cidade. Em relação a isso, buscamos saber o que a população fixa/ permanente da cidade pensa a respeito do que é pior com a presença dos turistas no balneário (ver Gráfico 03).

Assim, para os residentes fixos deste balneário, com a chegada dos turistas e conseqüente aumento de sua população nos finais de semana e nas altas temporadas, os maiores problemas causados segundo a amostra pesquisada foram: em primeiro lugar, as sujeiras das praias (27\%), pois o descaso e desrespeito daqueles que as freqüentam, vê-se refletido nas areias de suas belas praias ao final do dia, onde grandes quantidades de lixo se amontoam ao longo dos seus 22,5 km de praias; em segundo, o trânsito / congestionamento (24\%) nas entradas e saídas da cidade, no início e término dos feriados, comprometendo a mobilidade (dos residentes fixos) para suas residências e locais de trabalho, em terceiro, a falta d'água (23\%), já que em muitos bairros da cidade, nas altas temporadas, a falta d'água torna-se um problema sério, deixando, às vezes, a população de algumas regiões, dias a fio sem uma gota d'água. Nessas últimas festas de final de ano de 2008, vimos a gravidade do grande aumento da população, em que algumas áreas com altos índices de concentração populacional, não foi possível evitar a falta d'água, mesmo com todos os esforços da CETESB em sanar tal problema. Em quarto lugar, a falta de segurança (9\%) que apesar do grande número de policiais nas ruas e das câmeras de segurança 56 espalhadas pela cidade não é o suficiente para conter pequenos furtos nas regiões da orla marítima; juntos, em quinto lugar, as filas (8\%) e a queda na qualidade do atendimento da saúde $(8 \%)$ e, em último lugar, a sujeira das ruas (1\%).

\footnotetext{
${ }^{56}$ Com mais de 1.200 câmeras vigiando a cidade e sua orla marítima de $22,5 \mathrm{~km}$, uma das maiores orlas do litoral sul de São Paulo, Praia Grande é considerada uma das cidades mais vigiadas por câmeras em todo o país. Ainda segundo, o site da Wikipedia (disponível em: http://pt.wikipedia.org/wiki/Praia_Grande_(S\%C3\%A3o_Paulo) com acesso em 21/01/2008, por Imário Vieira), hoje em dia, Praia Grande é a cidade com o maior número de câmeras de vigilância das américas e a segunda do mundo, perdendo apenas para a cidade de Londres, Inglaterra. E ainda segundo o site, essa estância tem a previsão de instalação de mais 900 câmeras, a partir de 2007, ultrapassando, desse modo, a cidade de Londres na quantidade de câmeras instaladas.
} 
Gráfico 03 - O que é pior com os turistas

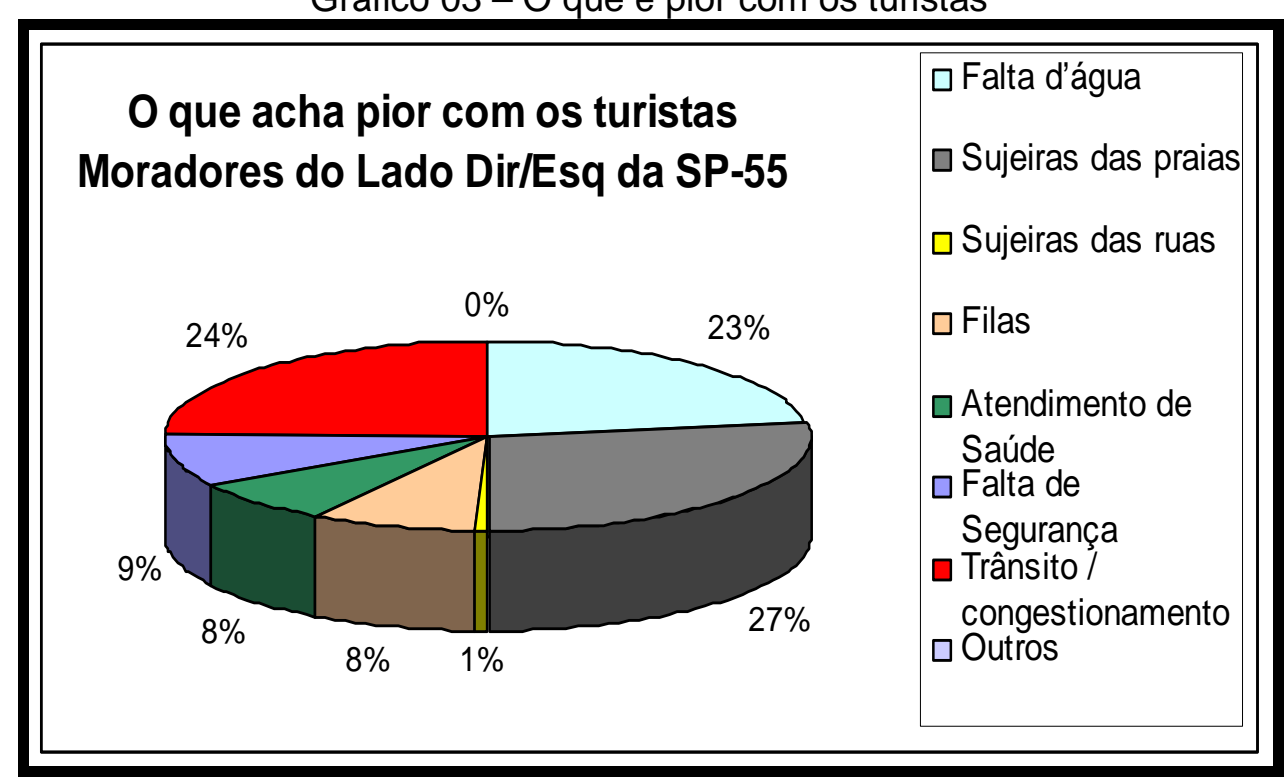

Fonte: Conforme trabalho de campo, realizado por Imário Vieira, entre os meses de maio e dezembro de 2007, especificamente nos dias 19/20/26/27 de maio, 30/Jun, 01/Jul, 04 e 05/Ago, 29 e 30/Set, 27 e 28/Out, 03 e 04/Nov, 01 e 02/Dez do ano de 2007. Elaborado por: Imário Vieira

No entanto, nos dias atuais, de acordo com estudos feitos pela prefeitura de Praia Grande, as áreas de maior densidade residencial desse balneário estão localizadas na sua área central, onde se encontra o seu sítio urbano. Nessa área (central), ou nas áreas mais próximas a São Vicente, a maioria das habitações tem índices superiores $46 \mathrm{hab} / \mathrm{ha}^{57}$. Cabe-se lembrar que, isso ocorre nessa região, devido ao fato de existirem, nessa parte da cidade, a maior concentração de residências verticalizadas. No entanto, a partir do Bairro Mirim (no sentido Mongaguá), encontramos do lado direito da SP-55, nos bairros Solemar e Trevo, uma alta densidade residencial, semelhante aos índices das regiões centrais. Já do lado esquerdo (da SP-55), a partir do Bairro Mirim, a grande maioria das residências tem índices inferiores a 30 hab/ha. E ainda, os mesmos índices inferiores a 30 hab/ha é também verificado em alguns pontos esporádicos e em

${ }^{57}$ Onde tem Hab/ha - lê-se habitantes por habitação. 
bairros próximos ao centro e no bairro de Solemar, na divisa da cidade com Mongaguá (ver mapa 07).

Dessa forma, tem sido um grande desafio para a administração pública local atender a uma crescente demanda por melhorias em tantas áreas e para uma população cada vez maior durante os finais de semana, férias e nas altas temporadas, principalmente nas regiões mais próximas ao centro da cidade e mais próximas às suas vias de acesso.

Cabe-se ressaltar que os turistas das regiões metropolitanas, dos dias atuais, buscam lugares de fácil acesso, servidos por rodovias rápidas, modernas e com viagens de curta duração com os pólos emissores de turismo. Temos, ainda, o fato de que, uma boa parte dos turistas das grandes metrópoles busca regiões litorâneas onde possa desfrutar do sol e mar e, inclusive, que sejam lugares de fácil acesso e com viagens de curta duração. Desse modo, Praia Grande, com a entrega da segunda pista da Rodovia dos Imigrantes, inaugurada em 17 de dezembro de 2002, tornou-se uma boa opção para essa população da região do planalto e adjacências.

Portanto, todo este desenvolvimento que tem passado esta cidade-média paulista, com a valorização do seu solo urbano, principalmente nas áreas próximas à orla marítima e após tantos anos de exploração imobiliária e turística, tem trazido conseqüências boas e más para a atual população desse balneário. Perguntamos então, como está esta população? Quais suas características? Quais são essas conseqüências boas e ruins? Onde está a população mais carente dessa estância? 
Mapa 07 - Densidade residencial por setor Censitário 2000

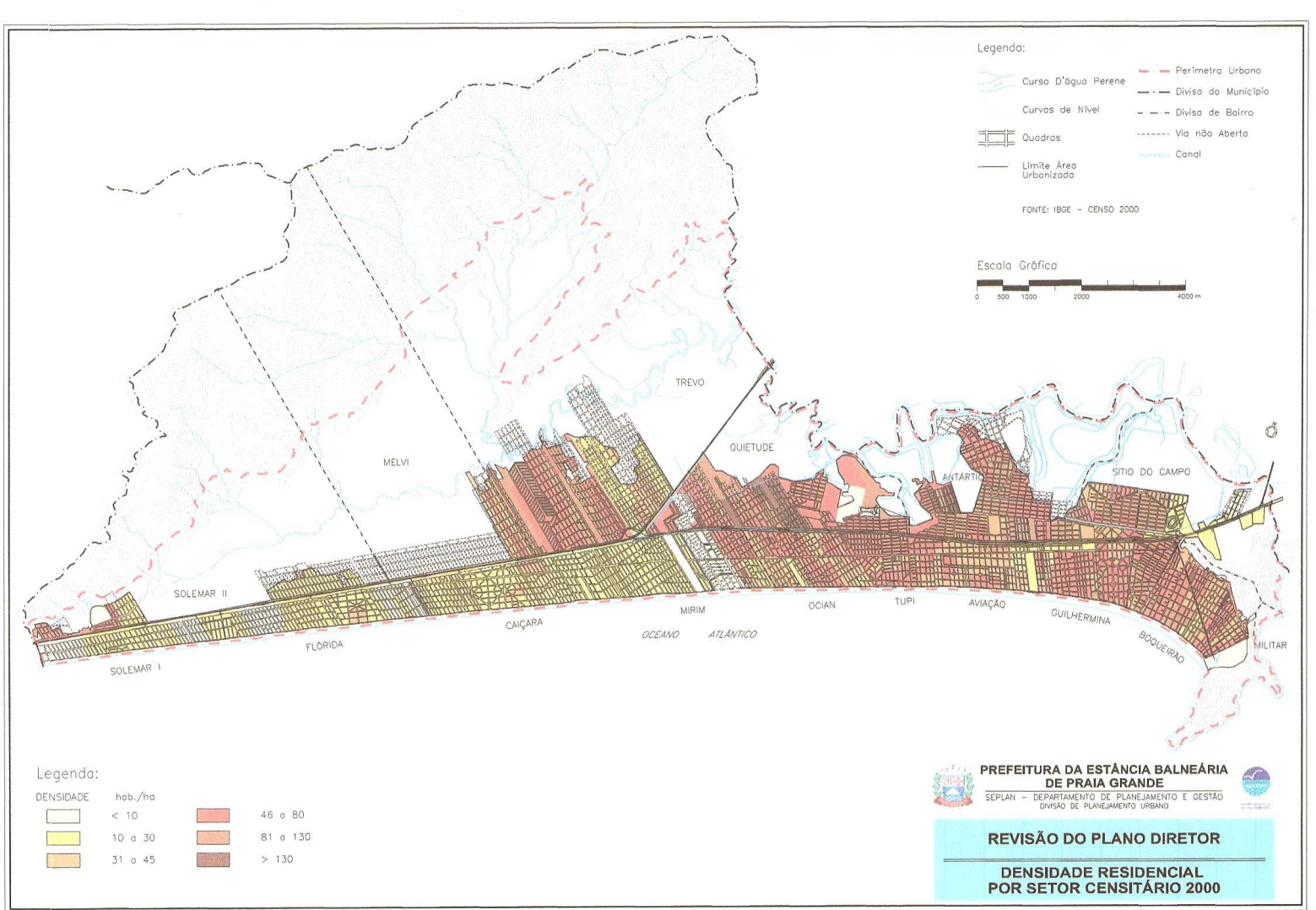

Fonte: Prefeitura da Estância de Praia Grande,SP 
No próximo item, falaremos um pouco sobre a população de Praia Grande, a procedência da amostra pesquisada antes de fixarem residência nesse balneário e onde está localizada a sua população mais carente, entre outros detalhes. Abordaremos ainda, um pouco mais dessas conseqüências para a população, mas sem a finalidade de um aprofundamento específico e detalhado dessas questões, mas sim, o de levantar algumas informações gerais e que, de certa forma, afetam a população fixa e ou permanente da região praiagrandense.

\section{3 - A população de Praia Grande e sua parcela mais carente}

Em uma matéria do jornal A Tribuna (A TRIBUNA, Santos, 24 abr. 1983. Especial Cidades. Capa.), o arquiteto Eliseu de Andrade Junior, na segunda metade do século passado, comentou:

“(...) nos últimos anos centenas de pessoas, a maioria de Cubatão, transferiram-se para Praia Grande, provavelmente para fugir aos problemas decorrentes da poluição. Em razão disso começaram a surgir os grandes núcleos habitacionais, exigindo dos órgãos públicos, municipais e estaduais, atuação semelhante à que é imprescindível na orla da praia“.

Buscando conhecer um pouco mais dessa população praiagrandense, e em busca de respostas para o que nos informou o arquiteto, Eliseu de Andrade Junior, tentamos identificar por meio de pesquisa de campo de fonte primária, a composição de uma amostra da população desse balneário. Assim, contando com 400 questionários para as populações mais próximas do lado esquerdo da Rodovia SP 55 - no sentido Mongaguá e outros 400 questionários para as regiões do lado direito da mesma rodovia (ver maiores detalhes da pesquisa no Anexo $A$ desta dissertação), realizadas durante os finais de semana e feriados (entre os meses de maio e dezembro de 2007), identificamos o local de procedência da amostra pesquisada antes de fixarem sua residência em Praia Grande. Verifica-se pelos resultados obtidos nessa amostra que $57 \%$ da população entrevistada de Praia Grande são procedentes da própria RMBS, sendo que desse total, $42 \%$ são representadas por migrantes de três cidades da região em questão e são elas: São Vicente (23\%), Cubatão (9\%) e Santos (10\%). O restante 
desses $58 \%$ é composto por pessoas de outras cidades da RMBS (2\%), os nascidos em Praia Grande (4\%), pessoas da região de São Paulo (26\%), do ABC $(12 \%)$, de outras regiões de São Paulo (13\%) e nascidas em outros estados (1\%). Esses números mostram a forte ligação de Praia Grande com as cidades vizinhas pertencentes à Região Metropolitana da Baixada Santista. Do montante que resta, $30 \%$ são de outras regiões do estado de São Paulo e 13\% de outros estados da federação. Dessa forma, de acordo com o que apontaram nossos levantamentos, percebemos que o que nos relatou o arquiteto Eliseu de Andrade Junior, ao dizer que centenas de pessoas de Cubatão migraram para Praia Grande, não foge à realidade, pois $10 \%$ desta amostra da população entrevistada são provenientes dessa cidade (ver tabela 03 e gráfico 04 ).

Tabela 03 - Local de procedência antes de viver em Praia Grande, SP

\begin{tabular}{|l|c|c|c|}
\hline \multicolumn{4}{|c|}{ Resultado da Pesquisa A - Lado Dir/Esq da SP-55 } \\
\hline & Lado Dir SP-55 & Lado Esq SP-55 & Total \\
\hline Santos & 32 & 41 & 73 \\
\hline São Vicente & 74 & 92 & 166 \\
\hline Cubatão & 45 & 36 & 81 \\
\hline Outros-RMBS & 22 & 8 & 30 \\
\hline São Paulo & 14 & 108 & 122 \\
\hline ABC Paulista & 5 & 47 & 52 \\
\hline $\begin{array}{l}\text { Outras regiões do } \\
\text { Estado de São Paulo }\end{array}$ & 9 & 51 & 60 \\
\hline $\begin{array}{l}\text { Nasceu em Praia } \\
\text { Grande }\end{array}$ & 95 & 14 & 109 \\
\hline $\begin{array}{l}\text { Nasceu em outro } \\
\text { estado }\end{array}$ & 104 & 3 & 107 \\
\hline Total & 400 & 400 & 800 \\
\hline
\end{tabular}

Fonte: Conforme trabalho de campo, realizado por Imário Vieira, entre os meses de maio e dezembro de 2007, especificamente nos dias 19/20/26/27 de maio, 30/Jun, 01/Jul, 04 e 05/Ago, 29 e 30/Set, 27 e 28/Out, 03 e 04/Nov, 01 e 02/Dez do ano de 2007. Elaborado por: Imário Vieira 
Gráfico 04 - Local de procedência antes de viver em Praia Grande, SP

\section{Procedência antes de vir Praia Grande Lado Esquerdo da SP- 55}

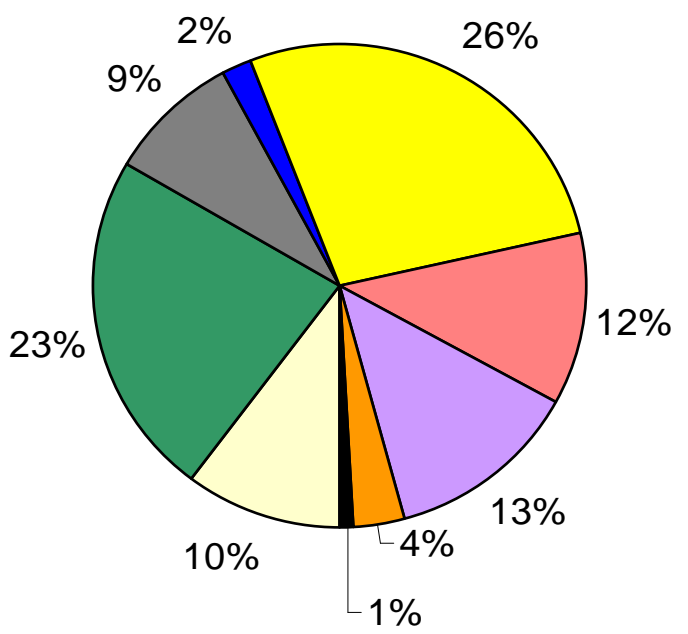

$\square$ Santos

São Vicente

Cubatão

Outros-RMBS

São Paulo

ABC Paulista

Outras regiões-SP

Nasceu em Praia Grande

- Nasceu em outro estado

Fonte: Conforme trabalho de campo, realizado por Imário Vieira, entre os meses de maio e dezembro de 2007, especificamente nos dias 19/20/26/27 de maio, 30/Jun, 01/Jul, 04 e 05/Ago, 29 e 30/Set, 27 e 28/Out, 03 e 04/Nov, 01 e 02/Dez do ano de 2007. Elaborado por: Imário Vieira

Assim, após nossos levantamentos descobrimos que, com tantos migrantes que passavam a vir para Praia Grande, gerou-se uma demanda, cada vez maior, por novos núcleos habitacionais, o que, de certa forma, ativava ainda mais a especulação imobiliária e a expulsão de populações mais carentes das áreas mais próximas à orla e de maior valor.

Ao analisar o Balneário de Camboriú, Magda Starke Lee (1998, p. 80) destaca algo que se aplica à Praia Grande, quando ela diz que

"A atuação das empresas de construção civil, transformou não só a forma de construir, mas transformou também a forma de aquisição de uma casa de veraneio, a forma urbana local e a apropriação deste espaço. Uma vez que o capital passou a intermediar a construção e também a aquisição do produto, o apartamento, ele por sua vez passa a apropriar-se do espaço, valorizando algumas áreas em detrimento a outras. Desta maneira, os terrenos localizados na orla marinha, passam por uma rápida 
valorização, na medida em que a demanda por terrenos bem localizados crescia proporcionalmente ao número de construções".

Nesse mesmo sentido, o desenvolvimento da exploração imobiliária em Praia Grande não só transformou a forma de construir e a forma urbana, mas também a forma de apropriação desse espaço. $E$ com a conseqüente valorização de terrenos, casas e apartamentos e também devido aos altos custos do IPTU destas regiões mais próximas à orla, a área geográfica da Estância Balneária de Praia Grande é praticamente dividida em duas partes, o lado esquerdo e de melhor renda da SP 55 (no sentido Mongaguá) e o lado direito e mais carente desta rodovia.

No entanto, foi por meio de nossos levantamentos de fontes primárias e também por meio de fontes secundárias (pesquisadas em livros, jornais, periódicos e a órgãos públicos) que nos foi possível identificar onde está a população mais carente e da periferia da Estância Balneária de Praia Grande, ou seja, ela encontra-se do lado direito da SP 55. Conforme resultados desta mesma pesquisa constatamos que nossos levantamentos revelaram que $96 \%$ dos entrevistados que vivem do lado direito da SP-55 ganham de 1 a 5 salários mínimos e apenas 4\% dessa amostra da população tem rendimentos de 5 a 10 salários mínimos. Por outro lado, do lado esquerdo da mesma rodovia, a pesquisa apontou que apenas $23 \%$ dessa amostra da população ganha de 1 a 5 salários mínimos, enquanto que $64 \%$ ganha entre 5 a 10 salários mínimos e $13 \%$ dessa parcela da população tem rendimentos superiores a mais de 10 salários mínimos (ver Gráfico 05). 
Gráfico 05 - Renda familiar - Lado direito/esquerdo da SP-55

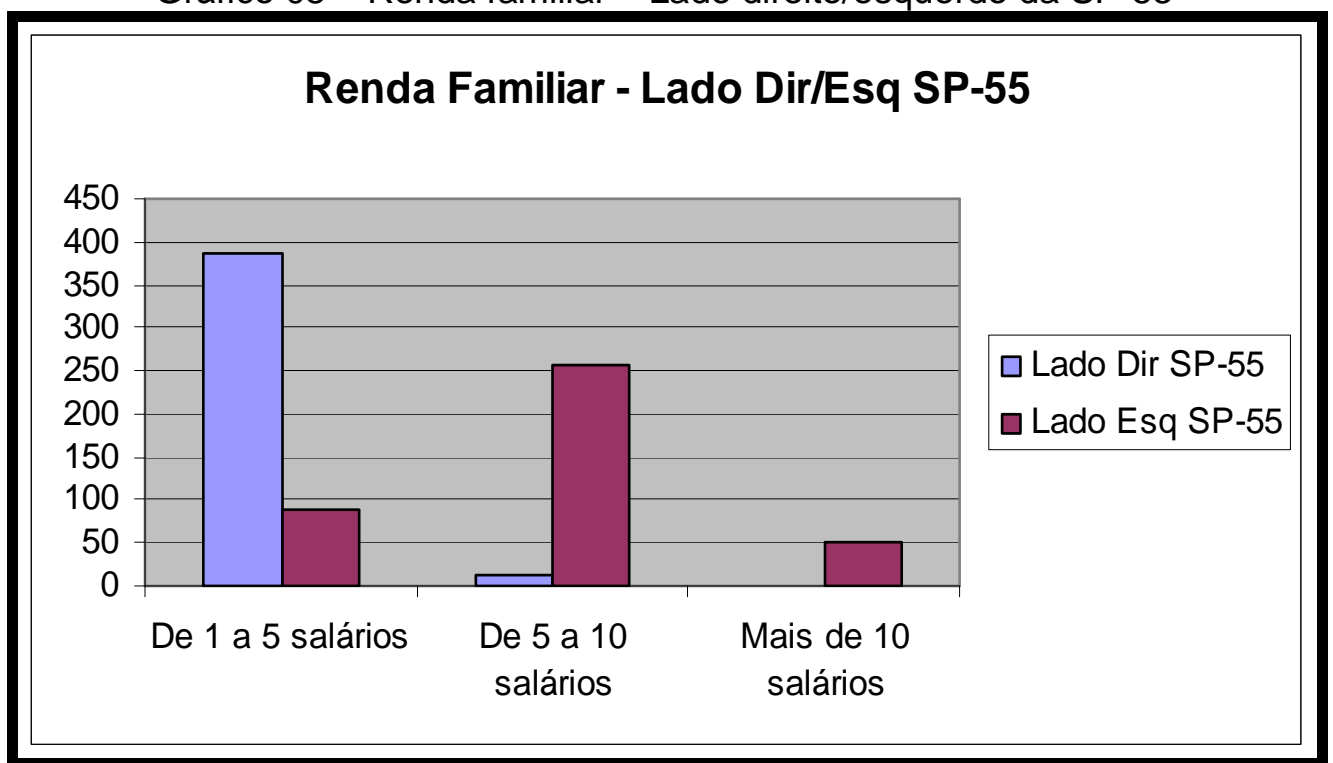

Fonte: Conforme trabalho de campo, realizado por Imário Vieira, entre os meses de maio e dezembro de 2007, especificamente nos dias 19/20/26/27 de maio, 30/Jun, 01/Jul, 04 e 05/Ago, 29 e 30/Set, 27 e 28/Out, 03 e 04/Nov, 01 e 02/Dez do ano de 2007. Elaborado por: Imário Vieira

Cabe-se destacar que, de acordo com essa amostra dos levantamentos realizados nota-se que a população mais carente tem menos acesso aos níveis de escolaridade mais altos. $\mathrm{Na}$ análise, constatamos que $31 \%$ dessa população mais carente tem da $1^{\underline{a}}$ à $8^{\underline{a}}$ série do ensino fundamental, contra os $18 \%$ da população do lado esquerdo da Rodovia SP-55. Em relação ao ensino médio, o lado direito da SP-55 encontra-se com $29 \%$ dessa parcela da população com o ensino médio incompleto e $22 \%$ completo. Já a população do lado esquerdo conta respectivamente com $7 \%$ e $19 \%$. No entanto, nota-se uma diferença considerável nos níveis superiores de graduação e pós-graduação, já que o lado mais carente conta com $9 \%$ de moradores com superior incompleto, $6 \%$ com superior completo e $0,5 \%$ da população com cursos de pós-graduação, contra as respectivas porcentagens do lado esquerdo de 31\%, 19\% e ainda contam com 4\% da população, além dos $0,25 \%$ dos pesquisados com pós-graduação Stricto Sensu (ver Gráfico 06). 
Gráfico 06 - Nível de escolaridade - Lado direito e esquerdo da SP-55

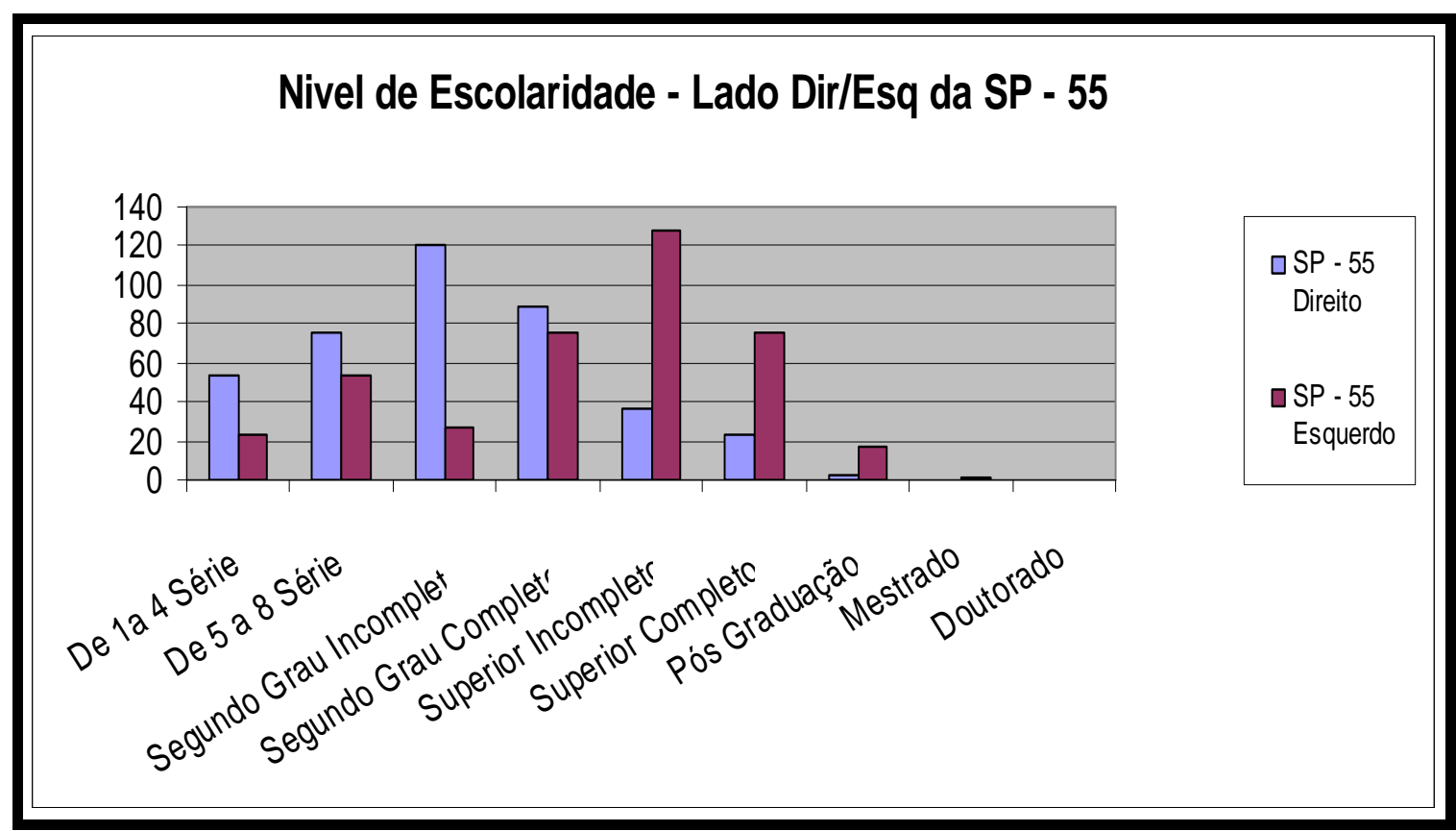

Fonte: Conforme trabalho de campo, realizado por Imário Vieira, entre os meses de maio e dezembro de 2007, especificamente nos dias 19/20/26/27 de maio, 30/Jun, 01/Jul, 04 e 05/Ago, 29 e 30/Set, 27 e 28/Out, 03 e 04/Nov, 01 e 02/Dez do ano de 2007. Elaborado por: Imário Vieira

Nossos levantamentos também revelaram a profissão dessa amostra da população pesquisada. Em nossas análises, constatamos que, entre os pesquisados, a maior parte desta população, ou seja, 58\% concentra-se nas áreas de vendas, comércio e serviços, $25 \%$ na área administrativa, $8 \%$ trabalha como servidor público, $5 \%$ na área da construção civil e, por último, 4\% dessa população trabalha em outras áreas. Como se pode verificar, esses resultados obtidos só nos mostram aquilo que já esperávamos, ou seja, a maior parte da população concentra-se nas área do comércio e prestação de serviços (ver gráfico 07). 
Gráfico 07 - Qual sua profissão - Lado direito e esquerdo da SP-55

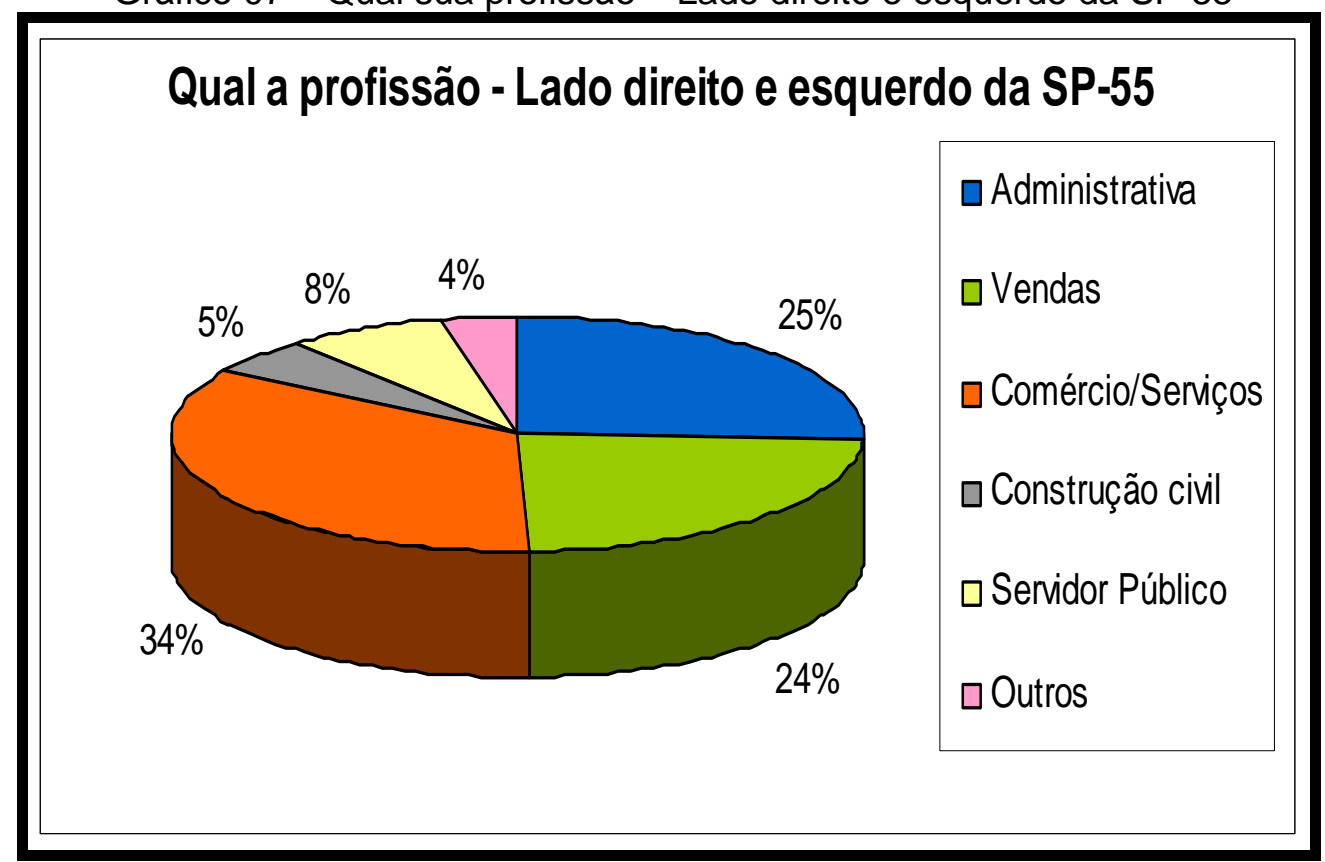

Fonte: Conforme trabalho de campo, realizado por Imário Vieira, entre os meses de maio e dezembro de 2007, especificamente nos dias 19/20/26/27 de maio, 30/Jun, 01/Jul, 04 e 05/Ago, 29 e 30/Set, 27 e 28/Out, 03 e 04/Nov, 01 e 02/Dez do ano de 2007. Elaborado por: Imário Vieira

Portanto, após nossos levantamentos de campo, ficou evidente a localização das populações mais carentes dessa estância balneária e elas se encontram do lado direito da SP-55, especificamente nas áreas mais distantes da orla marítima e portanto, menos valorizadas. Cabe-se notar que observam-se, em algumas dessas regiões, residências construídas com as condições mínimas de conforto para os seus moradores, principalmente nas áreas mais afastadas do mar e que seguem em direção a Mongaguá. Assim, nossas constatações em relação a essa população mais carente nos mostraram o grande contraste que existe entre as regiões do lado esquerdo, onde a especulação imobiliária é intensa, e a do lado direito da Rodovia Padre Manoel da Nóbrega (SP-55), onde se encontram as regiões menos valorizadas e mais carentes de Praia Grande.

Milton Santos (2005, p. 124-125) nos dá uma grande contribuição quando, analisando a urbanização brasileira, informa que 
“(...) operações de renovação empreendidas nos centros urbanos, cujo resultado é, também, o de ativar a especulação imobiliária expulsa parcela da população preexistente, impondo nova lógica à cidade como um todo. Esta lógica é a da valorização-desvalorização diferencial dos diversos setores urbanos".

Dessa forma, esse processo de valorização social, seguido da valorização econômica ao qual se deu em Praia Grande, criou uma distinção geográfica nessa cidade, expulsando a parcela de prováveis antigos moradores das regiões mais caras e valorizadas da orla. Essa valorização do solo urbano causou um processo de segregação, ao qual Castells apud Serra (1987, p. 82) diz que "a segregação não é um reflexo da estratificação social, mas sim um fenômeno específico de distribuição de um produto: o espaço". Por outro lado, Johnston (1980, p. 164) diz que "a segregação é um processo de associação da distância à estratificação social”. Assim, essa distância entre uma classe social e outra é estabelecida pelo sistema de valorização da terra, do espaço. Nesse sentido, Serra (1987, p. 83) complementa: "os grupos de rendas mais baixas estarão com a localização determinada pelo sistema de preço da terra".

Cabe-se lembrar que, no "1o Seminário Internacional de Urbanização Dispersa e Mudança do Tecido Urbano" que participamos em 2006 ${ }^{58}$, foi mencionado pelo Prof. Dr. Nestor Goulart Reis Filho que "o mercado imobiliário expulsa os pobres e redistribui os ricos, causando não só uma mobilidade social, mas também uma correspondente mobilidade espacial". Assim, no caso de Praia Grande, a população mais carente dessa cidade-média, devido à valorização do solo urbano nas regiões próximas ao mar e devido a uma intensa exploração imobiliária, vai se deslocando cada vez mais para as regiões mais distantes de sua orla e do seu sítio urbano. Isto ocorre, não só pelo fato dos imóveis serem mais caros nessas regiões próximas à orla, como também, no caso de Praia

\footnotetext{
${ }^{58}$ Este seminário do qual participamos, foi o "1ํ Seminário Internacional de Urbanização Dispersa e Mudança no Tecido Urbano", realizado de 21 a 23 de março de 2006 pelo LAP - Laboratório de Estudos sobre Urbanização, Arquitetura e Preservação, do Departamento de História da Arquitetura e Estética do Projeto da Faculdade de Arquitetura e Urbanismo da USP.
} 
Grande, pelo fato de serem mais caros os impostos prediais e territoriais urbanos (o IPTU).

Verificou-se que, em diversos pontos, à direita da rodovia SP 55 (no sentido Mongaguá) e nas regiões mais afastadas da orla, e próxima de regiões ainda inabitadas, observam-se residências construídas com as mínimas condições para uma vida com um pouco de dignidade, havendo até pequenos núcleos que enfrentam problemas de saneamento básico, água encanada e falta de ruas pavimentadas.

O crescimento de Praia Grande, por meio do desenvolvimento do turismo litorâneo, exploração imobiliária e processo de verticalização, iniciado a partir do século XX para cá, não pára de trazer investimentos e melhorias para a população local e flutuante desta cidade, porém, muitas situações desagradáveis vêm junto com a exploração do turismo de segunda residência e com todo esse crescimento urbano. Além de trazer boas conseqüências para seus cidadãos antigos e atuais, tais como melhorias na infra-estrutura urbana, na saúde, na educação, nos meios de comunicação, nos investimentos para a região, no considerável aumento de empregos nos setores do comércio e serviços para atender a esta crescente demanda turística, essas mudanças causadas pelo boom imobiliário por meio do turismo de segunda residência, também trouxeram conseqüências ruins. Assim, entre as várias conseqüências ruins, podemos citar: o processo de exclusão da população por meio da suburbanização dos mais carentes, a falta d'água nas altas temporadas, o acúmulo de lixo nas praias e lixões da região - com 0 comprometimento da balneabilidade de suas praias. Temos ainda, problemas com 0 atendimento da infra-estrutura básica, as filas nas padarias, nos supermercados e em outros serviços prestados à população, congestionamentos trazendo problemas de mobilidade devido à insuficiência das vias públicas em atender tão grande população nas altas temporadas, desrespeito às leis de trânsito, problemas sérios no sistema de atendimento de saúde nos ambulatórios e prontos-socorros da cidade nas altas temporadas, problemas com a segurança e tantos outros.

Em relação ao processo de verticalização do solo urbano e algumas de suas conseqüências, Santos (2005, p. 125) nos diz: 
“(...) A rapidez com que se instaura o processo de verticalização (...) tem como paralelo um processo de suburbanização. Como o número de pobres se expande ainda mais depressa, há pressão pela terra também entre os pobres, e o resultado é uma expansão geográfica da cidade, periferização (...)".

Diante disso, percebe-se a importância dos estudos acerca dos efeitos sociais do turismo e conseqüente verticalização, seus efeitos sobre o espaço, no processo de suburbanização e na vida dos habitantes mais carentes dos núcleos turísticos.

Após identificarmos a localização da população mais carente de Praia Grande, constatamos, no entanto, que nossos levantamentos não identificaram para onde foram os antigos caiçaras da região praiagrandense do final do século XIX e início do Século XX, pois conforme tabela abaixo, dos 800 moradores fixos entrevistados, somente um deles (com faixa etária entre 50-60 anos) teve pais caiçaras na região (ver tabela 04).

Tabela 04 - Ancestrais caiçaras / pescadores em Praia Grande, SP

\begin{tabular}{|l|c|c|}
\hline \multicolumn{3}{|c|}{ Teve ancestrais caiçaras / pescadores em Praia Grande } \\
\hline & Lado Dir SP-55 & Lado Esq SP-55 \\
\hline Sim & 1 & 0 \\
\hline Não & 399 & 400 \\
\hline Total & 400 & 400 \\
\hline
\end{tabular}

Fonte: Conforme trabalho de campo, realizado por Imário Vieira, entre os meses de maio e dezembro de 2007, especificamente nos dias 19/20/26/27 de maio, 30/Jun, 01/Jul, 04 e 05/Ago, 29 e 30/Set, 27 e 28/Out, 03 e 04/Nov, 01 e 02/Dez do ano de 2007. Elaborado por: Imário Vieira

Não foram identificados de forma conclusiva se os atuais moradores das regiões mais carentes dessa cidade-média paulista foram ou são remanescentes dos antigos moradores da comunidade caiçara da região do princípio do século passado. Nossas pesquisas também revelaram que, entre os entrevistados, tanto do lado direito quanto esquerdo da Rodovia SP-55, nenhum deles jamais morou 
em outra zona (das três existentes na cidade) além daquela que vive atualmente (ver Anexo $A$ - questionário $A$ - pergunta de número 8). Nesse sentido, sugeremse novos estudos e novos caminhos a serem percorridos de modo a buscar respostas para essa questão.

\title{
3.4. Os impactos ambientais e a qualidade de Praia Grande como Estância Balneária
}

A partir de reflexões dos estudos ${ }^{59}$ feitos sobre o turismo e seus impactos ambientais, Cruz (1995, p. 75) enuncia que,

\begin{abstract}
"Todo e qualquer tipo de empreendimento tem repercussões sobre o meio no qual está inserido, mesmo que estas possam ser consideradas insignificantes. O tamanho e a finalidade da obra, suas características físicas e as características físicas e sócio-ecônomicas de sua área de implantação é que, por sua vez, determinam a natureza dos impactos (negativos e/ou positivos) provenientes do empreendimento, bem como sua amplitude".
\end{abstract}

No caso de Praia Grande, o crescimento urbano causado pelos empreendimentos imobiliários (ligado ao turismo de segunda residência) trouxe conseqüências e impactos negativos e positivos para essa estância balneária. No entanto, o crescimento urbano influenciado pelos empreendimentos imobiliários, atividades turísticas e portuárias de seus vizinhos, também trouxeram impactos ao meio ambiente de Praia Grande por várias décadas.

Desde a inauguração da Ponte Pênsil em 1914, até a década de 1980, Praia Grande sofreu com os impactos ambientais causados pelo despejo dos esgotos de suas vizinhas Santos e São Vicente ${ }^{60}$ em suas praias, além dos próprios

\footnotetext{
59 "Turismo e impactos ambientais costeiros: Projeto Parques das Dunas-Via Costeira, Natal (RN).

60 Junto com a Ponte Pênsil, inaugurada em 1914, vieram também os emissários de esgotos de Santos e São Vicente. Nas laterais do piso desta ponte, onde está o leito para a travessia de pedestres com 1,4 metros de largura, lateralmente sobre a ponte passam 2 emissários de esgoto de $0,50 \mathrm{~m}$ e um terceiro com tubos de 0,65 m. Eram estes emissários que traziam os esgotos que deviam ser lançados ao longo do morro do Itaipu em Praia Grande. Esta obra foi um plano de saneamento elaborado por uma comissão chefiada pelo engenheiro e sanitarista Saturnino de Brito. Este emissário foi desativado
} 
resíduos produzidos por sua população e pelos turistas provenientes da metrópole de São Paulo e demais regiões metropolitanas do estado. Cabe-se ressaltar que o esgoto era jogado ao mar na região do "Canto do Forte" sem tratamento algum e nas épocas de altas temporadas isso se complicava ainda mais. Assim, por muito tempo, Praia Grande ficou conhecida e cognominada como região de praias sujas, poluídas e cheias de turistas de um dia, os ditos "farofeiros". Esses turistas, que vinham aos milhares, deixavam o reflexo de seu descaso pelo meio ambiente local com a grande quantidade de lixo que deixavam em suas praias sem a preocupação com os impactos ambientais que causariam.

Nesse sentido, Cruz (1995, p. 36), em sua dissertação sobre o turismo e os impactos em ambientes costeiros no Rio Grande do Norte, nos diz que "a poluição das praias por deposição de lixo e depredação de outros recursos naturais estão entre os mais freqüentes impactos desencadeados pelo turismo de massa sobre o ambiente natural (...)". Portanto, às vezes, para conter impactos causados por regiões metropolitanas como a de São Paulo, propulsoras de grandes impactos ambientais sobre regiões turísticas como a de Praia Grande, muitas vezes, requerem do poder público medidas radicais.

Assim, na primeira metade da década de 1990, o número de turistas de um dia, diminuiu consideravelmente devido a medidas radicais tomadas pela administração pública da cidade, reduzindo, em parte, as agressões ao meio ambiente causadas pelas centenas de ônibus (ver foto 39) que chegavam à região de Praia Grande todos os finais de semana e feriados, ameaçando sua qualidade como estância balneária.

Vale lembrar que, por várias décadas, até antes da década de 1990, era muito comum vermos grandes quantidades de ônibus estacionados nas imediações de suas praias e em avenidas como a Av. Kennedy.

Dentro desse contexto, a primeira medida tomada para diminuir os impactos ambientais e os danos à imagem do balneário, que por muito tempo foi cognominado como lugar de "praias sujas e de pobres", foi a aprovação dessa lei,

em 10 de junho de 1980, encerrando o lançamento de 300 l/segundo de esgotos em Praia Grande, o que veio a ajudar na despoluição de suas praias. 
a Lei Municipal 793, que passou a vigorar a partir de 08 de janeiro de 1993. Essa lei municipal visava barrar os turistas de um dia ou os famosos "farofeiros" e devolver o glamour de suas praias dos tempos de outrora e mudar a imagem negativa em relação ao seu balneário. A lei previa bloqueios nos acessos à cidade e impedia a entrada dos ônibus com o pagamento de multas para aqueles que eram detidos clandestinamente, reduzindo em boa parte, as agressões ambientais causados pelos mesmos.

Foto 39 - Avenida Presidente Kennedy lotada de ônibus - Década de 1970

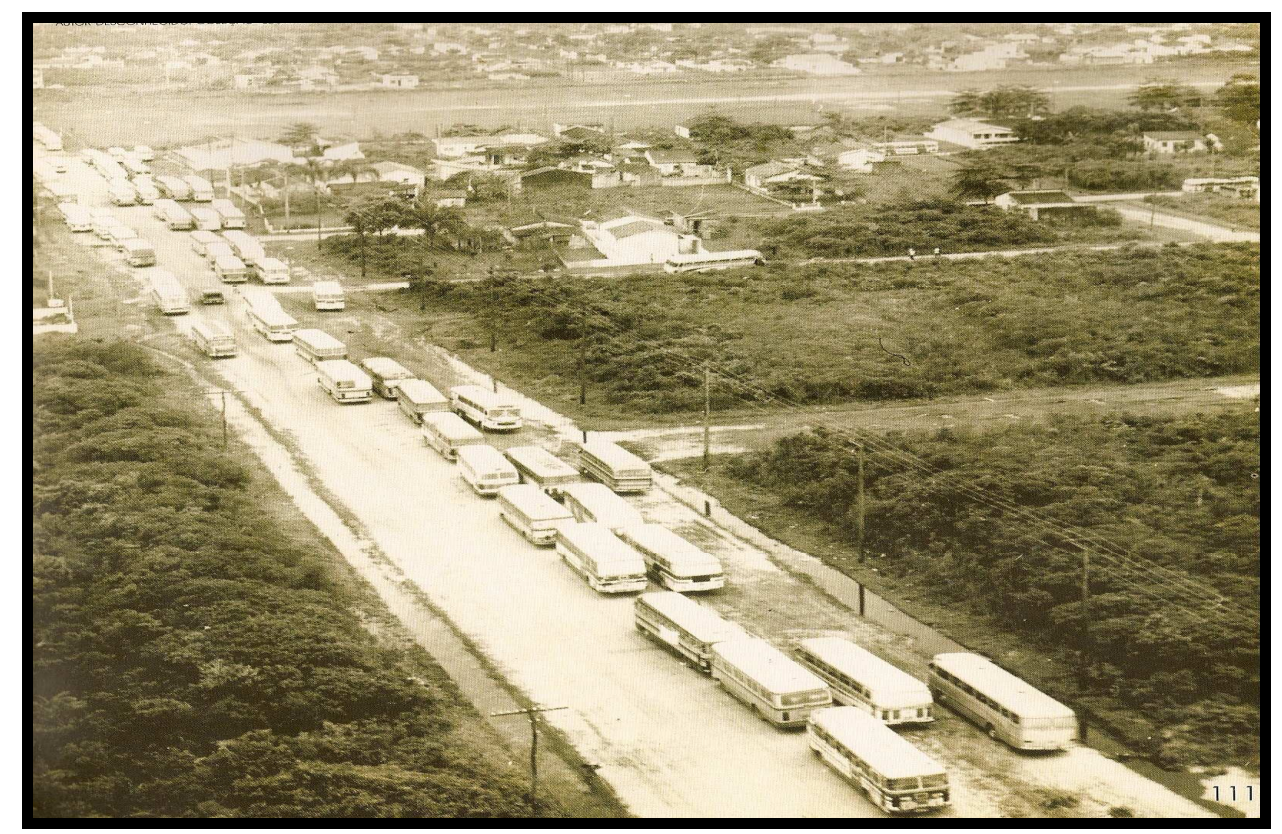

Fonte: SIQUEIRA, Fátima Valéria; SILVA, Mônica Solange Rodrigues; CALIS, Magna Flora. Paisagens da memória: história de Praia Grande. Praia Grande, SP: Prefeitura da Estância Balneária de Praia Grande, 2002, p. 111. Autor desconhecido

Na década de 1970, eram enormes as quantidades de ônibus que chegavam a Praia Grande todos os finais de semana. Nessa foto, vemos parte da Av. Kennedy, na região próxima ao campo de Aviação, repleta de ônibus que traziam os turistas de um dia para essa estância balneária. Notamos que, tanto no canto esquerdo, quanto no direito dessa avenida, ainda era possível encontrarmos lotes contendo parte da Mata Atlântica.

No entanto, um dos fatores que podem afetar a imagem e sua conseqüente qualidade como estância balneária e que estão diretamente ligados com os 
impactos ambientais causados pela população em decorrência da deposição de lixo nas praias, esgotos clandestinos, entre outros, é a balneabilidade. Em relação a isso, em nossos levantamentos junto à população local (800 moradores fixos) e aos turistas (1650 turistas), constatamos que os resultados apontaram algo muito preocupante em relação ao que os turistas acham da balneabilidade das praias deste balneário, pois, verificou-se que para $61 \%$ dos turistas entrevistados, os níveis de balneabilidade são considerados entre regulares (48\%) e ruins (13\%). No entanto, para os moradores locais, $42 \%$ dessa parcela da população praiagrandense considera suas praias entre regulares $(24 \%)$ e ruins (18\%). No entanto, para $39 \%$ dos turistas, as praias estão entre boas (33\%) e ótimas (6\%), já para $58 \%$ dos moradores fixos entrevistados, elas estão entre boas (38\%) e ótimas (20\%). Sendo assim, por tratar-se de um balneário cuja economia depende, em boa parte, do turismo de segunda residência, ter $61 \%$ dos entrevistados considerando suas praias entre regulares e ruins, não é algo nada bom para a cidade (ver gráficos 08 e 09).

Gráfico 08 - O que acha da balneabilidade - Lado dir/esq da SP-55

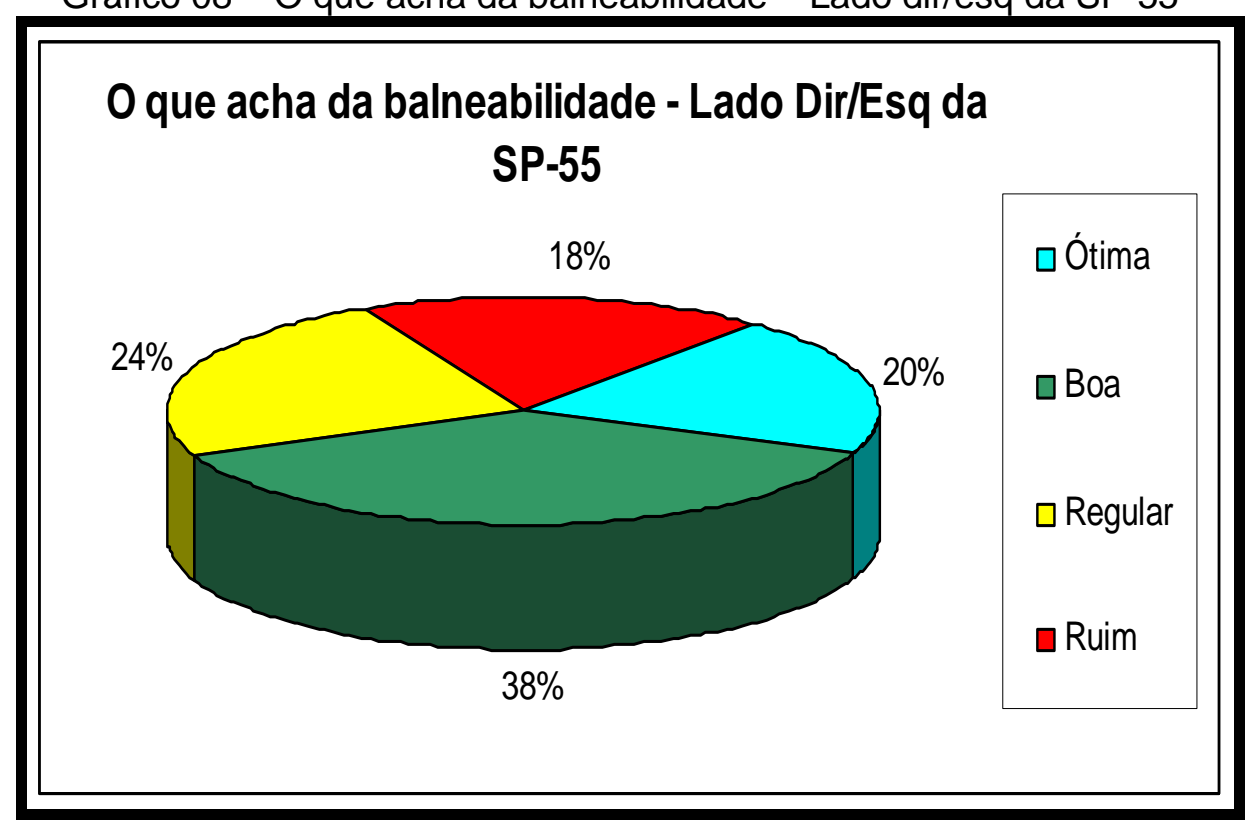

Fonte: Conforme trabalho de campo, realizado por Imário Vieira, entre os meses de maio e dezembro de 2007, especificamente nos dias 19/20/26/27 de maio, 30/Jun, 01/Jul, 04 e 05/Ago, 29 e 30/Set, 27 e 28/Out, 03 e 04/Nov, 01 e 02/Dez do ano de 2007. Elaborado por: Imário Vieira 
Gráfico 09 - O que acha da balneabilidade - Turistas

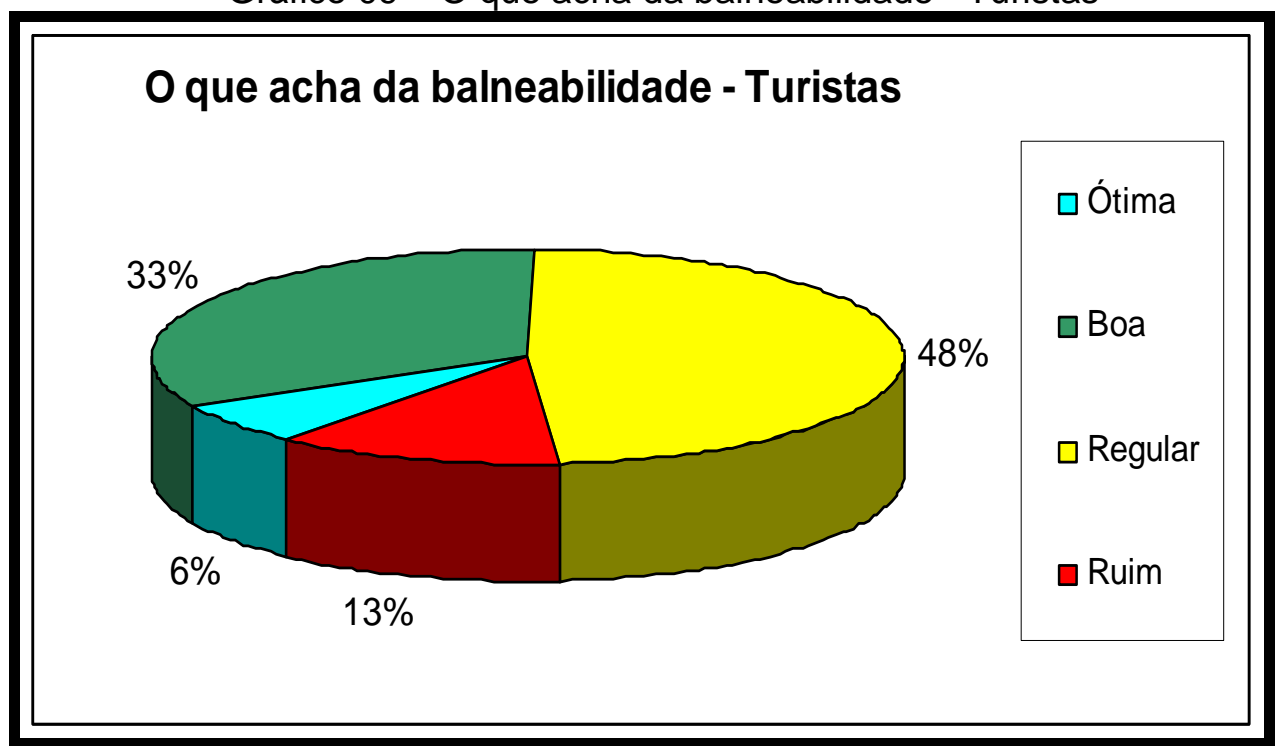

Fonte: Conforme trabalho de campo, realizado por Imário Vieira, entre os meses de junho de 2007 e janeiro de 2008, nos dias 07/08/09/10 de junho, dias 26/27/28/29 de julho, dias 18/19/20 de agosto, dias 07/08/09 de setembro, dias 12/13/14 de outubro, dias 02/24/25 de novembro, dias 01/02/21/22/23 de dezembro de 2007 e dias 04/05/06/17/18/19/20 de janeiro de 2008. Elaborado por: Imário Vieira

Cabe-se lembrar que, a medida em que vai caindo a qualidade ambiental e os níveis de balneabilidade de uma estância balneária, a tendência é que vá perdendo os fatores que atraem os turistas e os investimentos para sua região, devido ao fato da mesma perder sua qualidade enquanto estância, pois aquilo que a fazia singular, diferente de outras localidades turísticas, vai, aos poucos, sendo perdido.

Portanto, nos dias atuais, uma das prioridades da estância e da RMBS é aumentar a coleta de esgoto na região e chegar o mais próximo possível dos $100 \%$ de esgoto tratado até 2011/12. Praia Grande, apesar de possuir sistema de coleta de esgotos, o qual, segundo dados ${ }^{61}$ da EMPLASA pesquisados em 2005, atende a cerca de $46 \%$ da área urbana, não é suficiente para evitar que caia a sua qualidade enquanto estância balneária em determinadas épocas do ano,

${ }^{61}$ EMPLASA - Carga Orgânica Poluidora de Origem Doméstica, segundo os Municípios: 2005. 
principalmente em épocas em que a população da cidade chega quase a quintuplicar.

Neste contexto, tomando-se por base o que diz o artigo de O Diário de São Paulo (O DIÁRIO DE SÃO PAULO, São Paulo, 20 jan. 2008, Caderno A. 5 p.), a CETESB $^{62}$, que monitora 53 praias das 85 existentes na Região Metropolitana da Baixada Santista, informa que após último teste realizado no início de 2008 , apenas 05 das 53 praias analisadas estavam próprias para banho, pois as demais praias, consideradas impróprias, encontravam-se com altos índices de coliformes fecais. As chuvas ${ }^{63}$ recentes que caíram na região agravaram ainda mais a situação. Infelizmente, entre as 05 praias próprias para uso, nenhuma era de Praia Grande.

Assim, segundo esse artigo, devido ao fato de nenhum dos participantes da RMBS terem $100 \%$ dos seus esgotos tratados e ainda devido ao fato de existirem ligações clandestinas, que chegam ao mar por meio de galerias pluviais, com as chuvas freqüentes dos últimos dias, o esgoto dessas galerias são levados para o mar, agravando ainda mais a balneabilidade das praias, o que, de certa forma, prejudica sua imagem e qualidade como estância balneária. Isso sem falar da superpopulação que a RMBS abriga no verão. A SABESP ${ }^{64}$ enuncia que:

"Embora o cenário atual seja preocupante (...) 'O programa Onda Limpa já está em operação e deve injetar $R \$ 1,23$ bilhão da recuperação ambiental da região até 2011', afirma Reynaldo Ribeiro, superintendente da Sabesp na Baixada Santista".

${ }^{62}$ CETESB - Companhia de Tecnologia de Saneamento Ambiental.

63 Ao falar da presença das chuvas nas condições de balneabilidade das praias paulistas, Midaglia (1994, p. 70) relata:

"A presença de chuvas, intensificadas no período do verão, justamente no período de maior freqüência de banhistas, torna a situação ainda pior, uma vez que transporta lixo para as águas, criando condições para aparecimento de doenças de transmissão hídrica (...)".

Ainda dentro desse contexto, a pesquisadora nos diz que doenças de transmissão hídrica "são aquelas em que a água atua como veículo do agente infeccioso" (Midaglia, 1994, p. 70).

${ }^{64}$ SABESP - Companhia de Saneamento Básico do Estado de São Paulo. 
O artigo diz ainda,

"Entre os benefícios previstos estão a construção de dois emissários submarinos - em Santos e na Praia Grande -, e a elevação para 95\% nos índices da população atendida com rede de esgoto, que hoje chega a 62\%".

Outro aspecto a ressaltar, e que também afeta a sua imagem e condição de estância balneária, é a falta d'água causada nas altas temporadas em vários bairros da cidade. Em relação a isso, a SABESP informou que foi ampliada a produção de sete mil litros por segundo para nove mil, durante as festas de finais de ano (2007), mas, mesmo assim, disse que a quantidade não foi o suficiente para evitar o desabastecimento. Segundo a assessoria de imprensa dessa estatal, ela trabalha com a sua capacidade máxima e com um sistema integrado de abastecimento em toda a Baixada Santista, que minimiza, mas não resolve, o problema da falta d'água (Disponível em http://ultimasnoticias.org/2007/12/31/praia-grande-sp-falta-aguasabesp-pede-racionamento/, acesso em 21 de janeiro de 2008, por Imário Vieira).

Portanto, medidas urgentes devem ser tomadas quanto à questão ambiental e abastecimento de água por parte dos administradores públicos de Praia Grande e de toda e qualquer estância balneária, de modo a preservar seus recursos naturais e não afetar sua condição como estância balneária.

Outro fator a ser considerado é a quantidade de lixo gerada e que, segundo estudos $^{65}$ da EMPLASA, no ano de 2000, Praia Grande gerava 95,9 ton/dia. No entanto, segundo outro estudo promovido por essa mesma empresa no ano de 2005, os resultados apontaram que a produção de lixo diária era de 148,1 ton/dia. Assim, em 5 anos houve um aumento de $65 \%$ da quantidade de lixo diária produzida na cidade.

Entretanto, o lixo que mais preocupa e incomoda a moradores e turistas não é o lixo doméstico, produzido por eles e coletado já ensacados diante de suas

${ }^{65}$ EMPLASA - Resíduos Sólidos - Produção Diária e Índice de Qualidade de Aterros, segundo os Municípios : 2000-2005 
casas e condomínios pelas empresas contratadas, ao menos não por enquanto. Verificou-se que o lixo deixado nas praias por turistas e moradores, esse sim, os preocupa e muito, pois, segundo eles, essa sujeira pode comprometer a imagem que a cidade tem resgatado nas últimas duas décadas. Vale registrar que após terminarem de responder ao questionário, muitos desses moradores e turistas desabafaram conosco e disseram que sentem vergonha da imagem que vêem durante o dia, principalmente no final da tarde (ver foto 39).

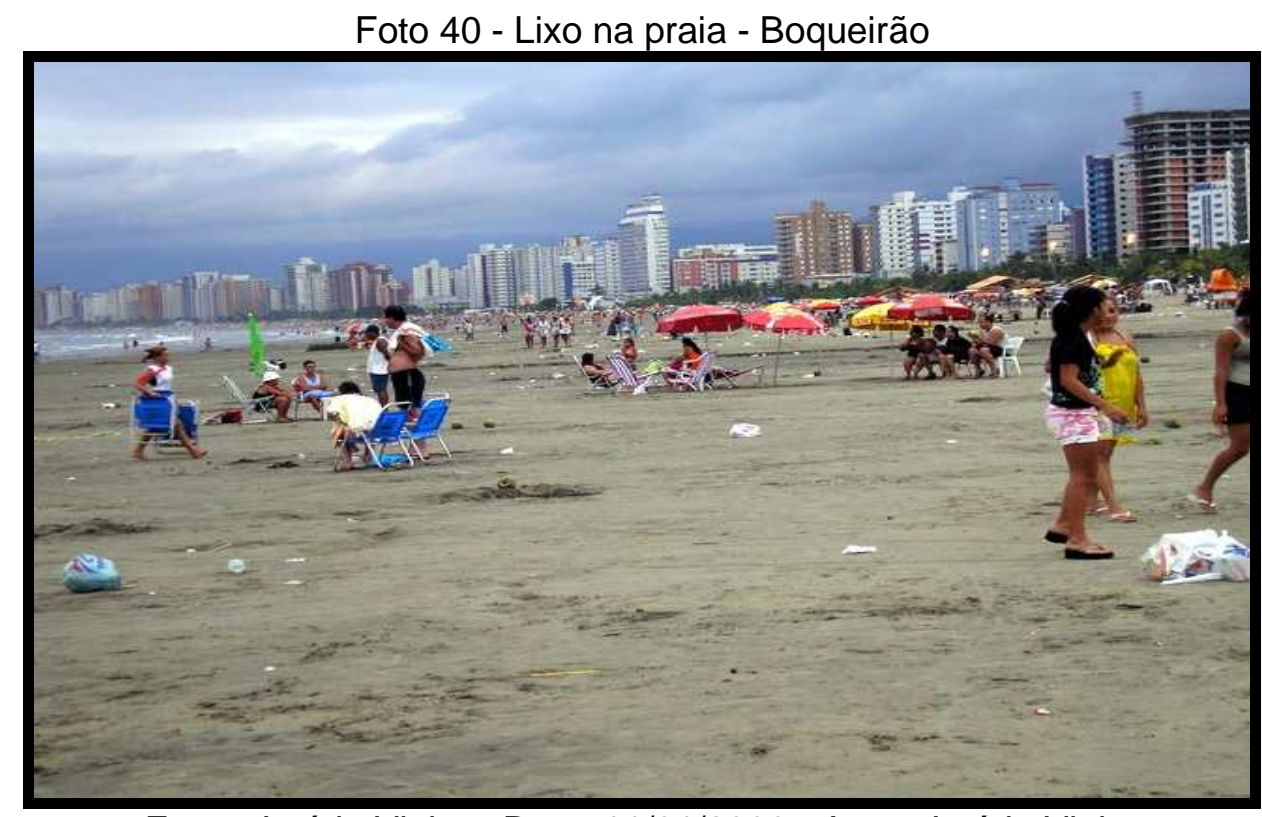

Fonte: Imário Vieira - Data: 11/01/2008 - Autor: Imário Vieira

O lixo deixado nas praias, além de ser algo feio e anti-higiênico, incomoda a muitos moradores de residência fixa e ocasional. Nessa foto, tirada em uma sexta-feira (durante a temporada de férias do mês de janeiro de 2008), vemos retratado o descaso ao meio ambiente por parte dos que moram e visitam esta estância balneária.

As pessoas entrevistadas, tanto turistas quanto moradores, ressaltaram que essa vergonha aumenta quando tem turistas estrangeiros nas imediações que ficam pasmos com a falta de respeito com o meio ambiente. Assim, após os resultados de nossos levantamentos junto a turistas e moradores fixos em relação ao que pensam da sujeira nas praias durante o dia constatamos que, tanto para os moradores fixos e/ou permanentes, quanto para os ocasionais e ainda para os 
turistas de um modo geral, os números obtidos em nossos levantamentos são preocupantes. Verificou-se que para os moradores fixos, apenas $28 \%$ da população pesquisada, votou de $0-4,61 \%$ dessa amostra deu notas de 5-8 e 11\% de 9-10. No entanto, para os turistas a situação é ainda pior, pois, para eles, apenas $9 \%$ da população pesquisada, votou de $0-4$, 68\% dessa amostra deu notas de 5-8 e 23\% dessa população deu notas de 9-10. Embora esse lixo seja gerado por turistas e moradores da cidade, para $91 \%$ dos entrevistados, a sujeira nas praias os preocupa e muito (ver Gráficos 10 e 11). Portanto, mesmo com a limpeza das praias que é realizada todas as noites, a população não está satisfeita com os resultados da mesma (ver mais detalhes no Anexo A - item 18 do questionário para os moradores fixos e item 20 para o de turistas).

Gráfico 10 - Nota para a sujeira das praias durante o dia Lado dir/esg da SP $-55^{66}$

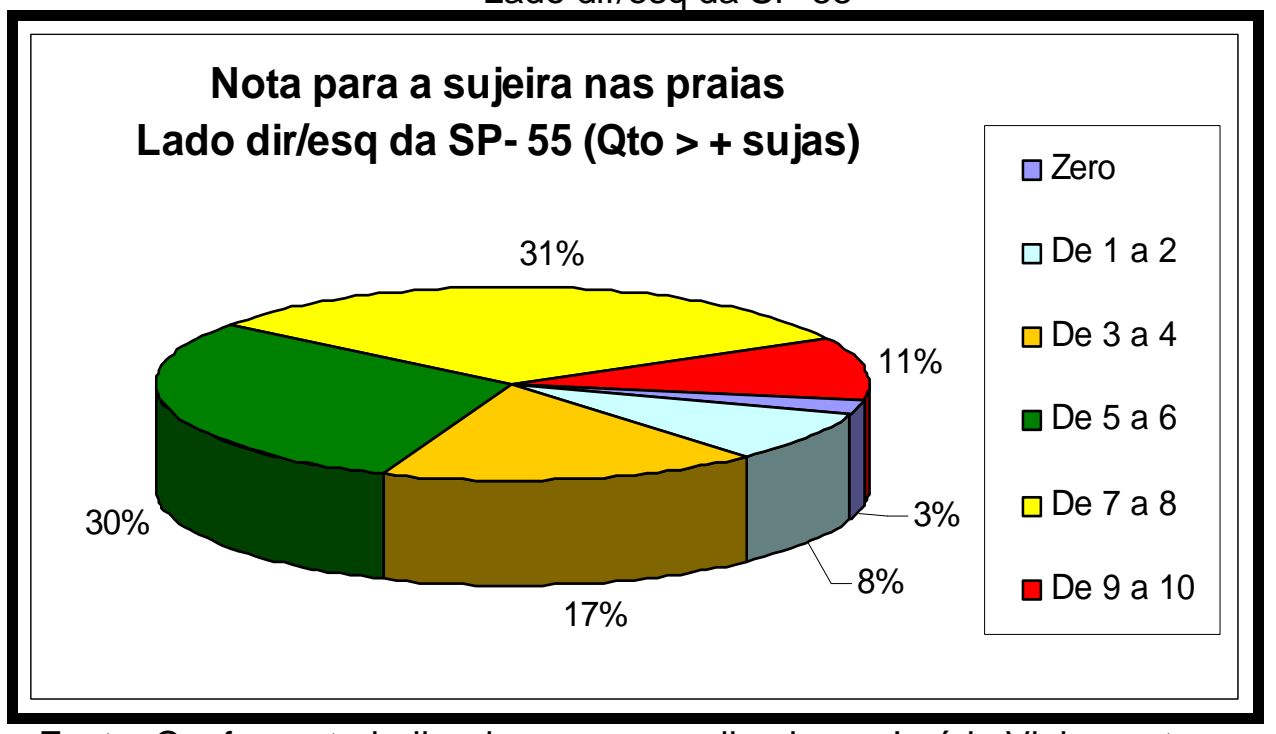

Fonte: Conforme trabalho de campo, realizado por Imário Vieira, entre os meses de maio e dezembro de 2007, especificamente nos dias 19/20/26/27 de maio, 30/Jun, 01/Jul, 04 e 05/Ago, 29 e 30/Set, 27 e 28/Out, 03 e 04/Nov, 01 e 02/Dez do ano de 2007. Elaborado por: Imário Vieira

${ }^{66}$ Quanto maior a nota, maior é a quantidade de sujeira nas praias. 
Gráfico 11 - Nota para a sujeira das praias durante o dia - Turistas

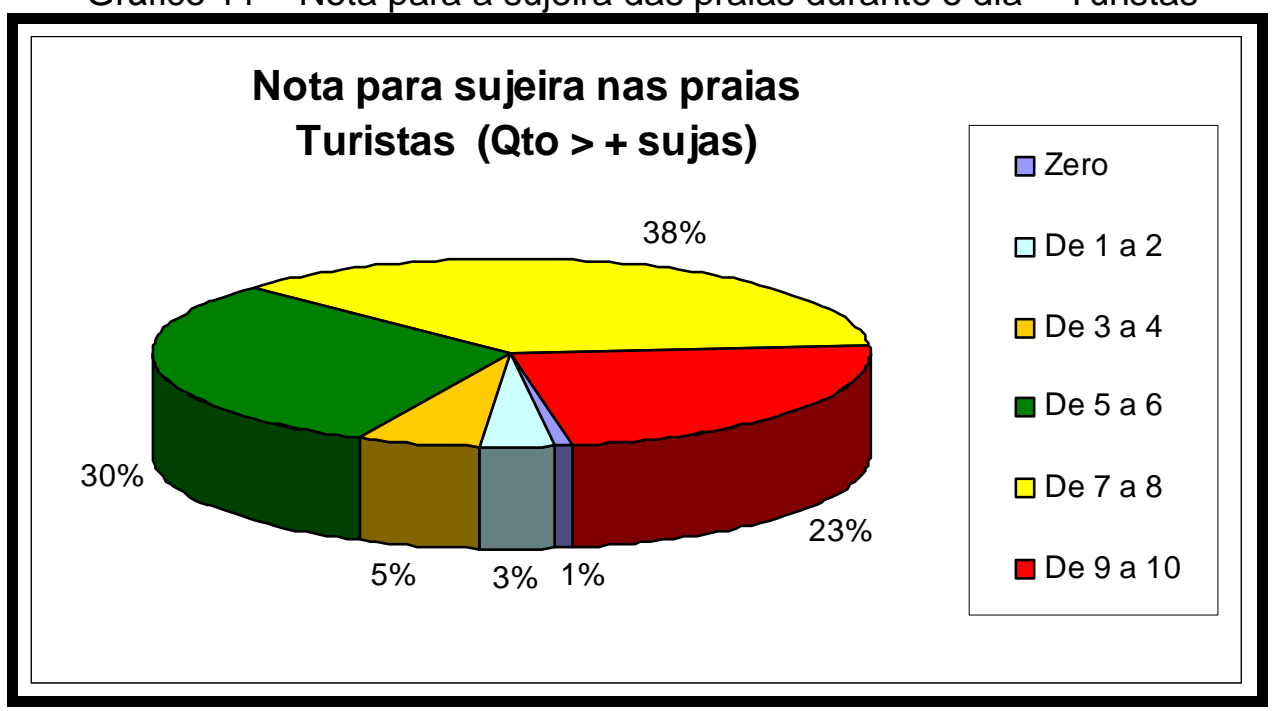

Fonte: Conforme trabalho de campo, realizado por Imário Vieira, entre os meses de junho de 2007 e janeiro de 2008, nos dias 07/08/09/10 de junho, dias 26/27/28/29 de julho, dias 18/19/20 de agosto, dias 07/08/09 de setembro, dias 12/13/14 de outubro, dias 02/24/25 de novembro, dias 01/02/21/22/23 de dezembro de 2007 e dias 04/05/06/17/18/19/20 de janeiro de 2008. Elaborado por: Imário Vieira

Em seus estudos sobre o turismo e meio ambiente no litoral paulista, Midaglia (1994, p. 68) nos fala:

"Dentre as causas que contribuem decisivamente para que haja uma queda de qualidade cênica da paisagem utilizada para recreação e lazer está o péssimo hábito de se deixar lixo por onde quer que se passe, tanto na areia, na água, na montanha, etc".

Cabe-se destacar que esse lixo deixado nas areias das praias, além de dar um aspecto feio ao lugar, gera maus odores, contamina o solo e facilita a proliferação de doenças. No entanto, lembramos que são muitos os adultos e principalmente crianças que adoram brincar de se enterrar nessas areias, tanto secas quanto molhadas, tornando-se suscetíveis de serem contaminados, sendo que, de acordo com a CETESB, essa contaminação pode se dar pelo contato com bactérias, vírus, protozoários e helmintos.

Dentro desse contexto, a pesquisadora Midaglia (1994, p. 68) ressalta: 
"O acúmulo de lixo é um dos fatores que funciona como um catalisador , capaz de transformar rapidamente uma praia agradável, com excelentes qualidades ambientais (ar, água e solo), em um enorme lixão (...), reduzindo drasticamente a sua atratividade e causando até mesmo repugnância entre os banhistas".

Assim, programas como aqueles feitos no passado com mutirões incentivando praias limpas, talvez possa ser uma opção a ser re-introduzida nesse balneário visando, dessa forma, minimizar os efeitos causados pelo acúmulo de lixo em suas areias nas altas temporadas e finais de semana.

Portanto, a cidade de Praia Grande, com a melhoria e modernização dos meios de comunicação e pelo fato de encontrar-se próxima às principais áreas metropolitanas do estado e receber um grande contingente de turistas destas regiões, moderniza-se buscando soluções para suas questões ambientais. Por fim, para não comprometer a sua qualidade enquanto estância balneária, Praia Grande, busca formas de aliar o seu crescimento urbano à proteção ambiental, e assim, melhorar sua infra-estrutura local para atender aos turistas, sua população local e ao seu novo tecido urbano.

\section{5 - O Novo tecido urbano de Praia Grande}

Desde o principio do século passado para cá, foram várias as mudanças instauradas em Praia Grande, visando consolidar ainda mais sua condição de estância balneária e um melhor atendimento aos moradores permanentes, aos de uso ocasional e aos turistas.

Até o final de 2006, essa estância possuía 16 bairros, mas após mudanças feitas por meio da revisão de seu Plano Diretor, votada e aprovada em dezembro de 2006, essa realidade foi mudada. Pela divisão de 1996-2006, eram 16 os bairros na cidade de Praia Grande e eram divididos por cores através do Projeto Rumo (ver figura 18). ${ }^{67}$

67 Denominado de Projeto Rumo, seu idealizador foi o arquiteto Antonio Freire de Carvalho Filho, o qual na época de sua criação e implantação era o Secretário de Trânsito e Transportes da cidade de Praia Grande. Ele foi criado em 1993, sendo finalizado em 1995. O intuito deste projeto era o de dividir os bairros em cores, para facilitar a vida dos turistas e moradores locais a identificarem em que bairros se encontravam através das cores diferenciadas das placas dos logadouros. Isso era feito com a sinalização em 
Vale destacar que, para um motorista ou pedestre identificar em qual bairro de Praia Grande se encontrava, nem sempre era uma tarefa fácil de ser realizada. Em Praia Grande, o Projeto Rumo identificava cada bairro por uma cor, facilitando a localização de vias e logradouros públicos e dando ao morador e ao turista um referencial marcante.

O autor do Projeto Rumo foi o arquiteto Antonio Freire de Carvalho Filho, secretário de Trânsito e Transportes em 1993. Mas os bairros com os nomes aprovados pela prefeitura da cidade não eram conhecidos pelos seus moradores.

Figura 18 - Projeto Rumo

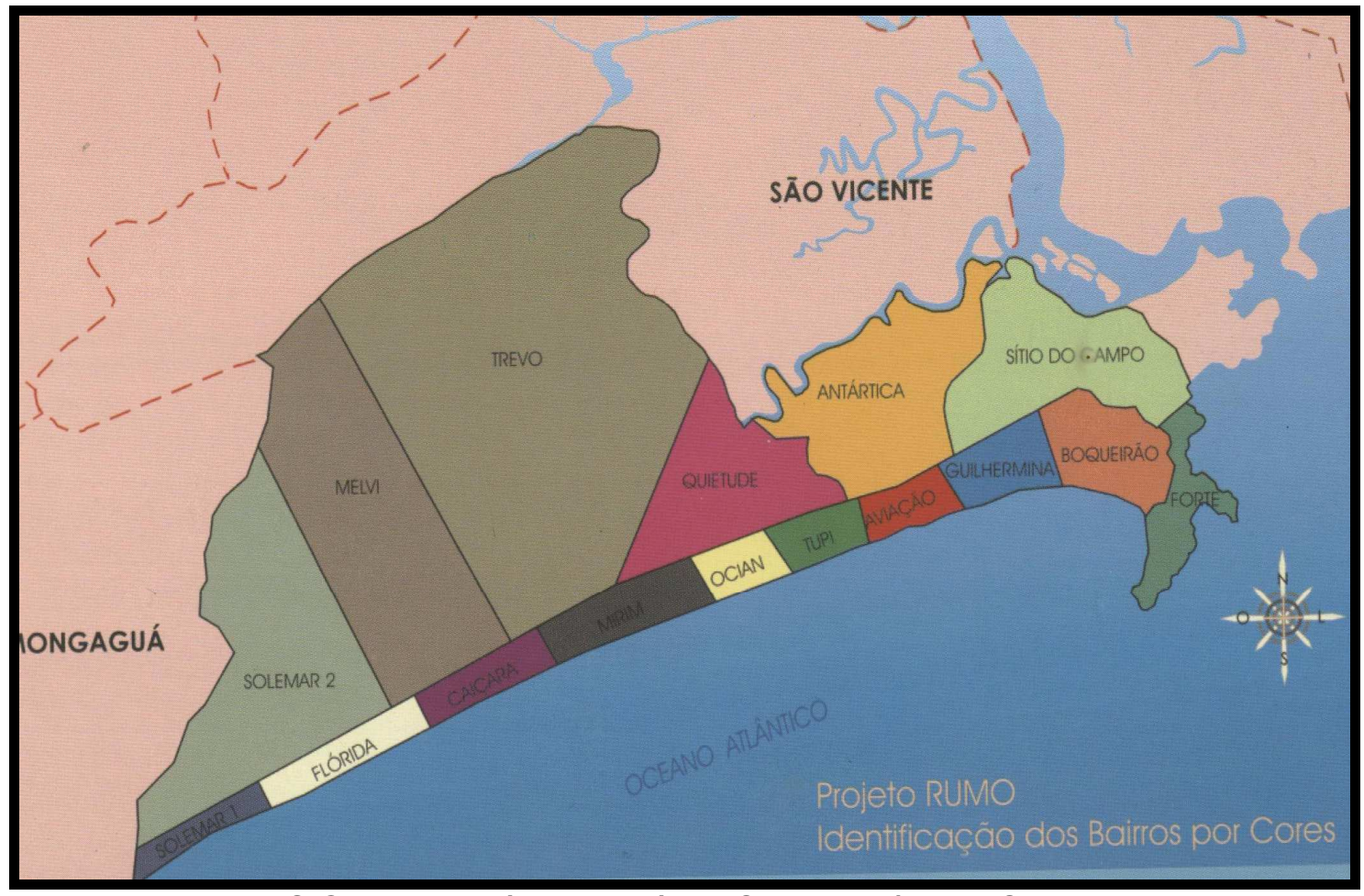

Fonte: SIQUEIRA, Fátima Valéria; SILVA, Mônica Solange Rodrigues;CALIS, Magna Flora. Paisagens da memória: história de Praia Grande. Praia Grande, SP: Prefeitura da Estância Balneária de Praia Grande, 2002, p. 81.

Nessa figura, vemos a divisão feita pelo Projeto Rumo, o qual dividia a Estância Balneária de Praia Grande em 16 bairros.

postes situados junto aos cruzamentos, com nome da via pública e o respectivo código de endereçamento postal, além da instalação de marcos divisórios dos bairros, situados nas avenidas Presidente Castelo Branco, Presidente Kennedy e Costa e Silva. 
No entanto, muitos dos bairros, na versão de 1996-2006 do Plano Diretor, tinham os seus nomes oficiais, mas os mesmos eram identificados pela população através de outros nomes. Isto causava uma grande confusão para turistas e moradores de segunda residência, exigindo assim uma revisão, adequando esse plano diretor, aos nomes pelos quais são conhecidos pela sua população local e desse modo facilitar a vida dos turistas.

De acordo com dados fornecidos pela prefeitura de Praia Grande, antes da década de noventa, a divisão era feita em distritos: o distrito da sede, ao leste e o distrito de Solemar, ao oeste da cidade, ou próximo à Mongaguá.

Após nossos levantamentos, descobrimos que uma outra distinção conhecida pelos moradores dessa estância era a de bairros litorâneos e interiores. "Os bairros litorâneos" eram aqueles que se encontravam junto à orla e aqueles que se encontravam do lado esquerdo das margens da Rodovia Padre Manuel da Nóbrega, a SP - 55 (sentido Mongaguá), e os da margem direita, eram conhecidos como "os bairros interiores".

Dessa forma, de acordo com o Plano Diretor de 1996-2006, "os bairros litorâneos" eram representados pelo: Canto do Forte; Boqueirão; Jardim Guilhermina; Campo de Aviação; Vila Tupi; Cidade Ocian; Vila Mirim; Vila Caiçara; Balneário Flórida; Jardim Solemar I.

Já “os bairros interiores” próximos à Rodovia Padre Manuel da Nóbrega, a SP-55, localizados a partir de sua margem direita (sentido Mongaguá) eram: Sítio do Campo; Antártica, Jardim Quietude; Jardim do Trevo; Melvi; e Jardim Solemar II.

Sendo assim, com a aprovação do Plano diretor que vigorou até dezembro de 2006, essa cidade-media era dividida em 16 bairros e são eles: Forte, Boqueirão, Guilhermina, Aviação, Tupi, Ocian, Mirim, Caiçara, Florida, Solemar I, Solemar II, Melvi, Trevo, Quietude, Antártica e Sítio do Campo. E, além dessa divisão geográfica feita por bairros, existia uma outra divisão feita para fins de arrecadação do IPTU, a qual dividia o município em três zonas: 
- a denominada de 1a Zona - compreendia a região que vai da orla marítima até cinco quadras da praia;

- a conhecida como $2^{\underline{a}}$ Zona, ia da $5^{\underline{a}}$ quadra até a Avenida Perimetral;

- e por fim, a 3르 Zona - que ia desta Avenida Perimetral até os limites da cidade.

No dia 06 de dezembro de 2006, foi aprovado pela Câmara Municipal e sancionado pelo prefeito da cidade, em 27 de dezembro de 2006, o novo Plano Diretor, que vigorará de 2007 a 2016. Este novo plano, com suas devidas revisões e inclusões de itens de suma importância para Praia Grande também tinha como prioridade resolver esse problema de confusão nos nomes dos antigos 16 bairros da cidade, bem como, adequar a cidade às exigências atuais no que tange ao seu uso e ocupação do solo, proteção de áreas de mananciais e tantos outros assuntos que necessitavam mudanças em relação ao plano anterior.

Santos (2006, p. 5), ao falar em seus estudos sobre a cidade de Itaperuna, localizada no estado do Rio de Janeiro, diz que "muitos bairros possuem um nome oficial, mas, são identificados pela população por meio de outras denominações". Desse modo:

"A lógica subjacente a isto é bastante clara, pois, na maior parte das vezes a população desconhece os nomes oficiais dos lugares. O que parece valer, de fato, são os nomes atribuídos pela tradição oral. (...) Essas tradições do senso comum assumem um significado que pode ser social, cultural, econômico etc. Por isso são reconhecidas pela população." (Santos, 2006, p. 6)

Ainda em sua análise sobre essa cidade do noroeste do estado do Rio de Janeiro, Santos (2006) aponta que "é interessante notar que a empresa de transporte que atua em Itaperuna, a Santa Lúcia, se baseia na nomenclatura popular para definir as suas linhas de ônibus". (Santos, 2006, p. 6)

Nesse sentido, percebemos por meio de nossos levantamentos que as linhas de transportes que servem a estância balneária de Praia Grande seguem parcialmente esse mesmo procedimento que foi adotado em Itaperuna, ou seja, 
este município utilizou-se da nomenclatura popular de seus bairros para algumas de suas linhas.

Hoje em dia, com a nova revisão do Plano Diretor traz 32 bairros para se adequar a essas mudanças de cunho social e de planejamento urbano de Praia Grande e também para facilitar a vida dos turistas que se viam confusos com nomes que não condiziam com as divisões oficiais da cidade.

\section{6 - Plano diretor e a lei de ordenamento do uso, da ocupação e do parcelamento do solo.}

Plano diretor ${ }^{68}$ é, em poucas palavras, a lei que organiza o crescimento e o funcionamento de uma cidade e/ou município com o estabelecimento de normas, políticas e diretrizes do desenvolvimento para o prazo de 10 anos. Ele deve abranger diretrizes e prioridades de cunho social, econômico e ambiental, não se limitando apenas à ordenação urbana.

A primeira lei visando promover e disciplinar o crescimento da Estância Balneária de Praia Grande, é a Lei Orgânica de 06 de abril de 1990, seguidas em 1996, pela lei que estabelecia o Plano Diretor do Município, Lei 152/96 e a Lei 153/96 de Ordenamento do Uso e da Ocupação e do Parcelamento do Solo.

O Plano Diretor da Estância Balneária de Praia Grande, criado pela Lei Complementar nำ152/96, para o período de 1996 a 2006, estabelecia diretrizes para as áreas da Saúde, Educação, Promoção Social, Ordenamento Territorial, Meio Ambiente, Infra-estrutura, Serviços Públicos, entre outras. Assim, o Plano Diretor visa promover um desenvolvimento ordenado e oferecer qualidade de vida aos seus moradores locais, aos de segunda residência e aos turistas.

No entanto, foi a Lei Complementar no 473, de 27 de dezembro de 2006, que aprovou a Revisão do Plano Diretor da Estância Balneária de Praia Grande para o período de 2007 a 2016. No artigo 1ํ desta lei complementar, diz-se que, "o

${ }^{68}$ A Lei Federal $n^{\circ} 10.257 / 01$, que contém o Estatuto da Cidade, propondo caminhos aos Poderes Públicos Municipais, marco importante para a regulamentação da função sócioambiental das cidades e das propriedades rurais e urbanas, consolida o Plano Diretor como um instrumento básico de construção política para desenvolvimento de uma cidade e/ou município. 
Plano Diretor é o instrumento básico da política de desenvolvimento urbano que tem por objetivo ordenar o pleno desenvolvimento das funções sociais da cidade e garantir o bem estar de seus habitantes".

O artigo $7^{\circ}$ menciona que este Plano Diretor terá vigência por um período de 10 (dez) anos a contar da data dessa Lei Complementar, devendo ser revisto, sistematicamente, a cada 4 (quatro) anos.

Por fim, vale ressaltar que é no Capítulo III art. 47ํqu vamos encontrar algo interessante sobre a Lei de Ordenamento do Uso, da Ocupação e do Parcelamento do Solo em Praia Grande, onde faz-se menção que são áreas de especial interesse ecológico e portanto, vedada ao uso do solo para fins urbanos:

I. O mangue;

II. A Serra do Mar;

III. O Morro do Xixová;

IV. A restinga, em áreas representativas;

V. As várzeas dos rios Preto e Branco.

Portanto, a existência de um Plano Diretor é um instrumento de grande valor para uma cidade, pois, além de organizar, regulamentar o espaço e a sua apropriação, delimita áreas de proteção ambiental. A sua elaboração e revisão, além de ter trazido mudanças que beneficiaram o turismo na cidade de Praia Grande, constituiu-se como um instrumento importante para a gestão urbana e para a promoção de um adequado desenvolvimento das atividades turísticas da cidade.

\section{7 - O Turismo de segunda residência e principais atrativos turísticos de}

\section{Praia Grande}

Segundo Lopes (1961, p. 74-76), em Praia Grande, um dos primeiros atrativos turísticos no início do século passado, além das belezas naturais, foi um boato que se espalhou pelas regiões vizinhas de que existiam baleias em Praia Grande. E aí, o marketing boca-a-boca se encarregou do resto. Espalhavam-se boatos de que havia baleias que soltavam esguichos na praia do Boqueirão e 
todos queriam ir ao encontro de tal aventura. Ao chegarem em Praia Grande, se encantavam com as belezas naturais do lugar e com sua extensa orla marítima. Nunca as tais baleias foram vistas pelos turistas, mas, segundo conta, eles vinham aos milhares das mais variadas regiões da Baixada Santista e do Planalto Paulista.

Dessa forma, no início do século passado, a beleza natural de Praia Grande era o principal atrativo que levava os turistas à sua região. No entanto, com a intensificação do seu uso turístico, em especial, com a intensificação do turismo de segunda residência a partir do final da década de 1920, levou o então distrito de São Vicente, à introdução e à multiplicação de novos objetos técnicos para atender a essa demanda turística que passava a intensificar-se em suas praias.

Cruz (2003, p. 12), ao analisar o fenômeno do turismo, registra algo que se aplica à cidade de Praia Grande, quando nos diz:

\begin{abstract}
"A intensificação do uso turístico de dada porção do espaço geográfico leva à introdução, multiplicação e, em geral, concentração espacial de objetos, cuja função é dada pelo desenvolvimento da atividade".
\end{abstract}

Em Praia Grande, foram muitas as introduções, multiplicações e concentrações espaciais de objetos por meio do desenvolvimento dessa prática social do turismo, especialmente, a partir da década de 1960, com o incremento da motorização familiar devido ao crescimento da indústria automobilística e que, de certa forma, beneficiou grandemente os deslocamentos da população das grandes cidades para outras regiões. Vale ressaltar que, o turismo de segunda residência também foi grandemente beneficiado por essa motorização familiar e desenvolvimento da indústria automobilística. Em seu livro, Rodrigues (1997, p. 137) nos relata:

"Sem adentrar em excesso no processo de desenvolvimento do turismo, no litoral paulista, deve-se lembrar que com a implementação da indústria automobilística, a partir de 1960, aberta aos investimentos estrangeiros, incrementa-se o acesso à motorização familiar, que vai favorecer os deslocamentos de lazer e turismo para o litoral". 
Desse modo, com a popularização dos automóveis que, em décadas passadas, era apenas um privilégio das classes mais abastadas, o turismo, de um modo geral, saiu como beneficiário dessa nova realidade, a motorização familiar. Mas foi com o desenvolvimento econômico que ocorreu a partir de então, devido ao crescimento e desenvolvimento da indústria automobilística, implementação de novos parques industriais e petroquímicos, e conseqüente acumulação de capital, que o sonho de se conseguir uma segunda residência tornou-se passível de realização para outras classes sociais. Assim, com o sonho da obtenção de uma segunda residência realizado, a freqüência e o período de estada dessa população nos lugares turísticos também foi favorecido. Cabe-se ressaltar que, pelos dados obtidos nos nossos levantamentos feitos junto a 1650 turistas, ao longo de todas as praias dessa estância, tomamos conhecimento de que, dessa amostra pesquisada, $80 \%$ responderam que passam dois dias, ou seja, o final de semana, no balneário. $E$, dessa população, $52 \%$ vêm todas as semanas e $38 \%$ a cada 15 dias (veja mais detalhes no Anexo A dessa dissertação - itens 8 e 9 do questionário $\mathrm{B}$ ).

No entanto, notamos, por meio de outras informações obtidas nesse mesmo levantamento de fonte primária, que o perfil desse turista que visita o balneário de Praia Grande, quanto ao nível de escolaridade e renda familiar, é deveras muito bom. Os resultados apontaram que $53 \%$ dos pesquisados tem, no mínimo, nível superior, e os $47 \%$ restantes estão distribuídos da seguinte forma: $32 \%$ com segundo grau completo e incompleto (atual ensino médio), 10\% com $5^{\text {a }}$ a $8^{\text {a }}$ série (atual nível fundamental 2) e com apenas 5\%, com nível de escolaridade de $1^{\underline{a}}$ a $4^{\underline{a}}$ série (atual nível fundamental 1 - ver Gráfico 12). 
Gráfico 12 - Nível de escolaridade dos turistas

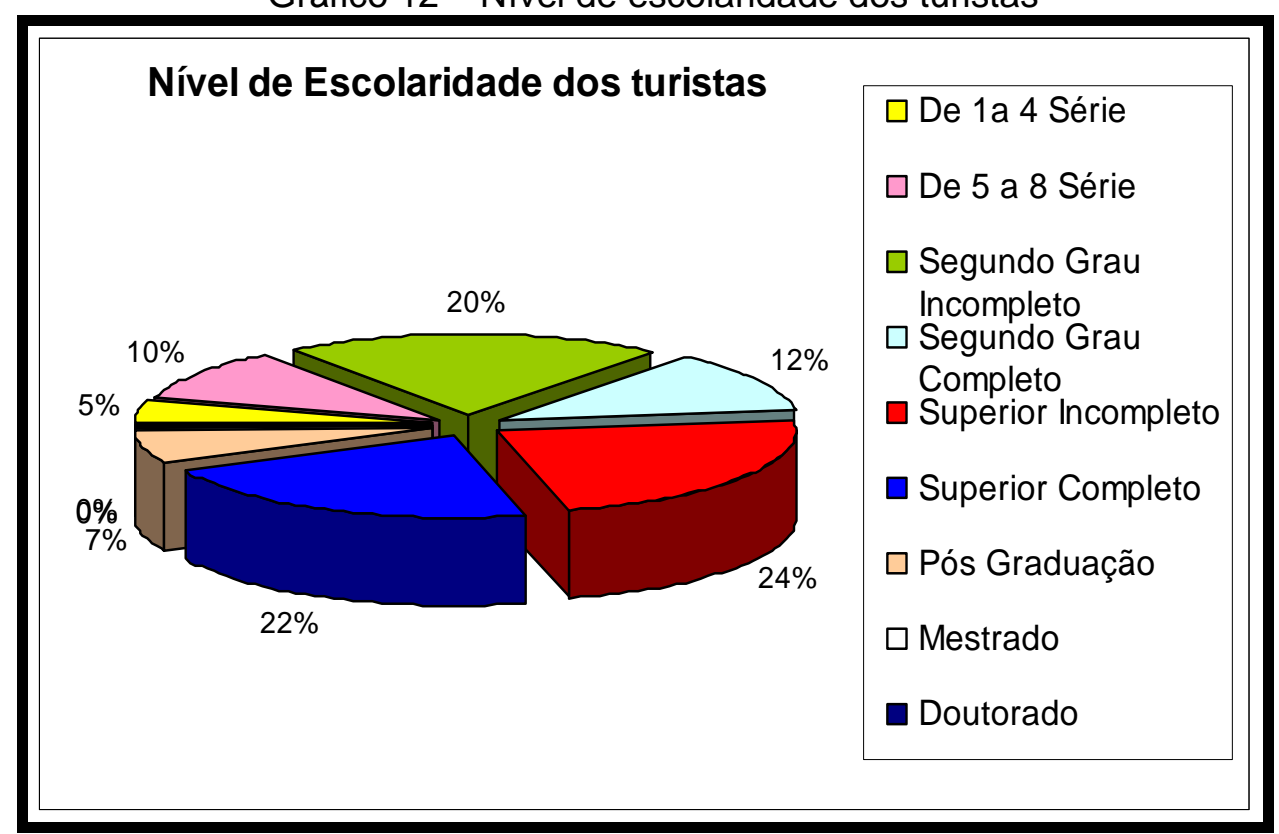

Fonte: Conforme trabalho de campo, realizado por Imário Vieira, entre os meses de junho de 2007 e janeiro de 2008, nos dias 07/08/09/10 de junho, dias $26 / 27 / 28 / 29$ de julho, dias $18 / 19 / 20$ de agosto, dias 07/08/09 de setembro, dias 12/13/14 de outubro, dias 02/24/25 de novembro, dias 01/02/21/22/23 de dezembro de 2007 e dias 04/05/06/17/18/19/20 de janeiro de 2008. Elaborado por: Imário Vieira

Portanto, o nível de educação dos turistas que visitam o balneário de Praia Grande é alto e os níveis de renda familiar, dessa mesma amostra de turistas, são ainda mais interessantes. Percebe-se, assim, pelo gráfico abaixo (ver Gráfico 13), que os percentuais de representatividade da renda familiar dos turistas que visitam Praia Grande é alto. No entanto, apenas 35\% da amostra pesquisada tem uma renda familiar, entre 1 e 5 salários mínimos, e a maior parte, ou seja, $65 \%$ destes turistas, tem respectivamente, 59\% com renda entre 5 e 10 salários e uma parcela com $6 \%$, cuja renda familiar que ultrapassa os 10 salários mínimos. Desse modo, pelos resultados obtidos, percebemos que as medidas tomadas em 1993, barrando a entrada de turistas de um dia e com todo o investimento feito pela administração pública e iniciativa privada na melhoria da infra-estrutura local, mostram que esses esforços surtiram o efeito esperado pelos órgãos públicos municipais diante dos percentuais apresentados nesse levantamento. 


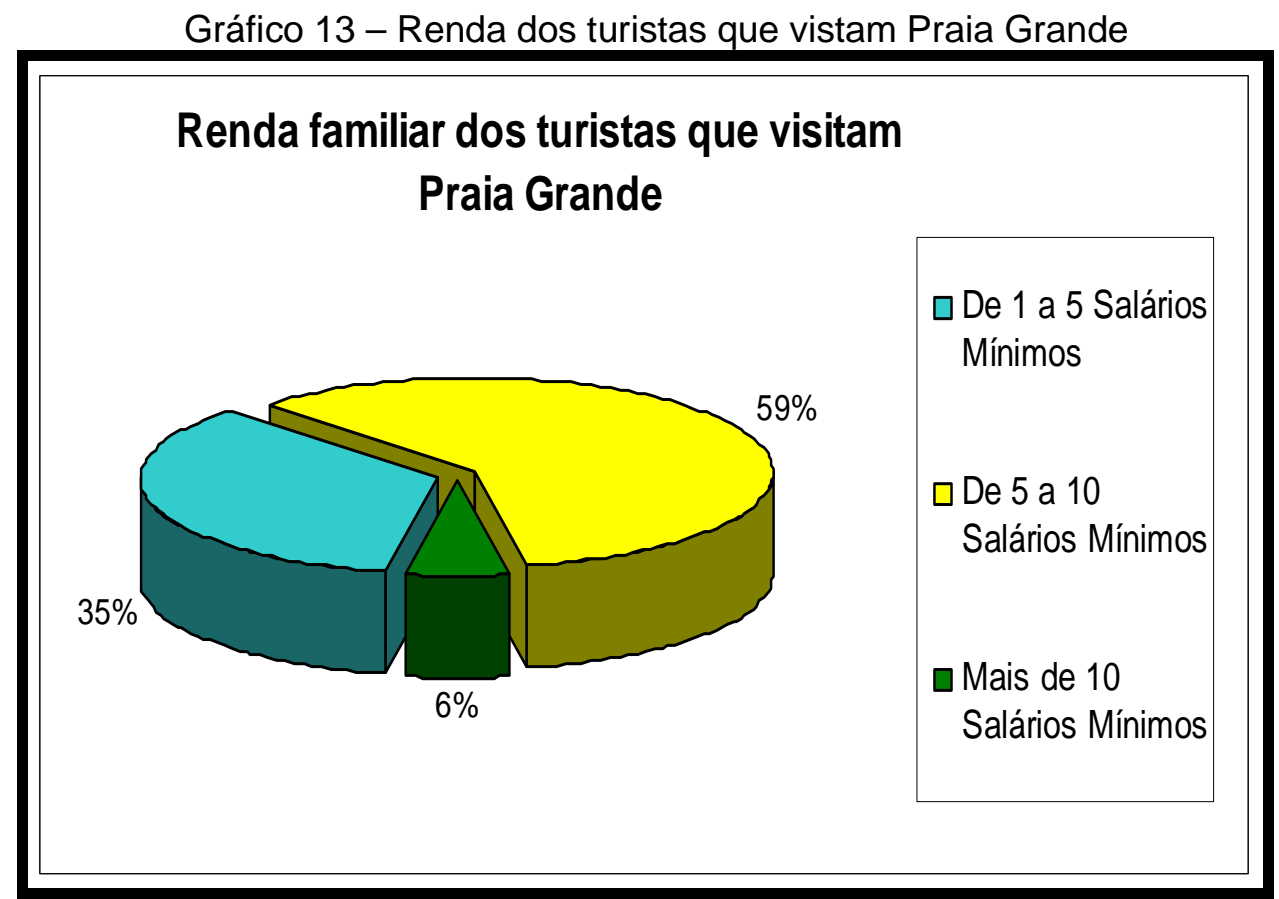

Fonte: Conforme trabalho de campo, realizado por Imário Vieira, entre os meses de junho de 2007 e janeiro de 2008, nos dias 07/08/09/10 de junho, dias 26/27/28/29 de julho, dias 18/19/20 de agosto, dias 07/08/09 de setembro, dias 12/13/14 de outubro, dias 02/24/25 de novembro, dias 01/02/21/22/23 de dezembro de 2007 e dias 04/05/06/17/18/19/20 de janeiro de 2008. Elaborado por: Imário Vieira

Entretanto, ao perguntarmos o que esses turistas pensam da infraestrutura atual dessa estância balneária, fomos surpreendidos pelos percentuais apresentados (vide mais detalhes no Anexo A - pergunta 11 do questionário $B$ ), ou seja, 50\% dos entrevistados consideram a infra-estrutura de Praia Grande ótima, $41 \%$ acham que é boa e apenas os $9 \%$ restantes desses turistas situaram a infra-estrutura local como regular (7\%) e ruim (2\%). No entanto, cabe-se ressaltar a necessidade de medidas urgentes no sentido de resolver as principais queixas desses turistas, pois segundo eles: 
Tabela 05 - O que deve ser melhorado em Praia Grande

Na sua opinião, o que deve ser melhorado em Praia Grande - Turistas

\begin{tabular}{|l|c|}
\hline Abastecimento de água & 571 \\
\hline Saúde & 41 \\
\hline Segurança & 475 \\
\hline Trânsito/faróis na saída da cidade com São Vicente & 498 \\
\hline Energia elétrica & 0 \\
\hline Esgoto & 29 \\
\hline Arruamentos & 12 \\
\hline Sinalizações & 24 \\
\hline Outros & 0 \\
\hline Total & 1650 \\
\hline
\end{tabular}

Fonte: Conforme trabalho de campo, realizado por Imário Vieira, entre os meses de junho de 2007 e janeiro de 2008, nos dias 07/08/09/10 de junho, dias 26/27/28/29 de julho, dias 18/19/20 de agosto, dias 07/08/09 de setembro, dias 12/13/14 de outubro, dias 02/24/25 de novembro, dias 01/02/21/22/23 de dezembro de 2007 e dias 04/05/06/17/18/19/20 de janeiro de 2008. Elaborado por: Imário Vieira

No que tange às suas queixas em relação ao que deve ser melhorado na cidade, três itens, disparam entre os mais votados e são eles: Abastecimento de água com 35\%, trânsito na saída da cidade com São Vicente 30\% e segurança com $29 \%$.

No entanto, nem tudo é somente queixa. Os turistas também elogiam os atrativos da Estância Balneária de Praia Grande. Nesse sentido, os principais atrativos turísticos da cidade são: em primeiro lugar, seus $22,5 \mathrm{~km}$ de praias com muito sol (ver foto 41), seus calçadões e ciclovias (ver foto 42), quiosques modernos e padronizados (ver foto 43), locadoras de bicicletas e carrocelas (ver foto 44) e triciclos, área destinada a esportes náuticos com aluguel de Jet ski, caiaques e passeio de banana boat, postos de salvamento, helicóptero monitorando todo a orla e tantos outros atrativos. 
Foto 41 - Vista parcial da orla marítima de Praia Grande

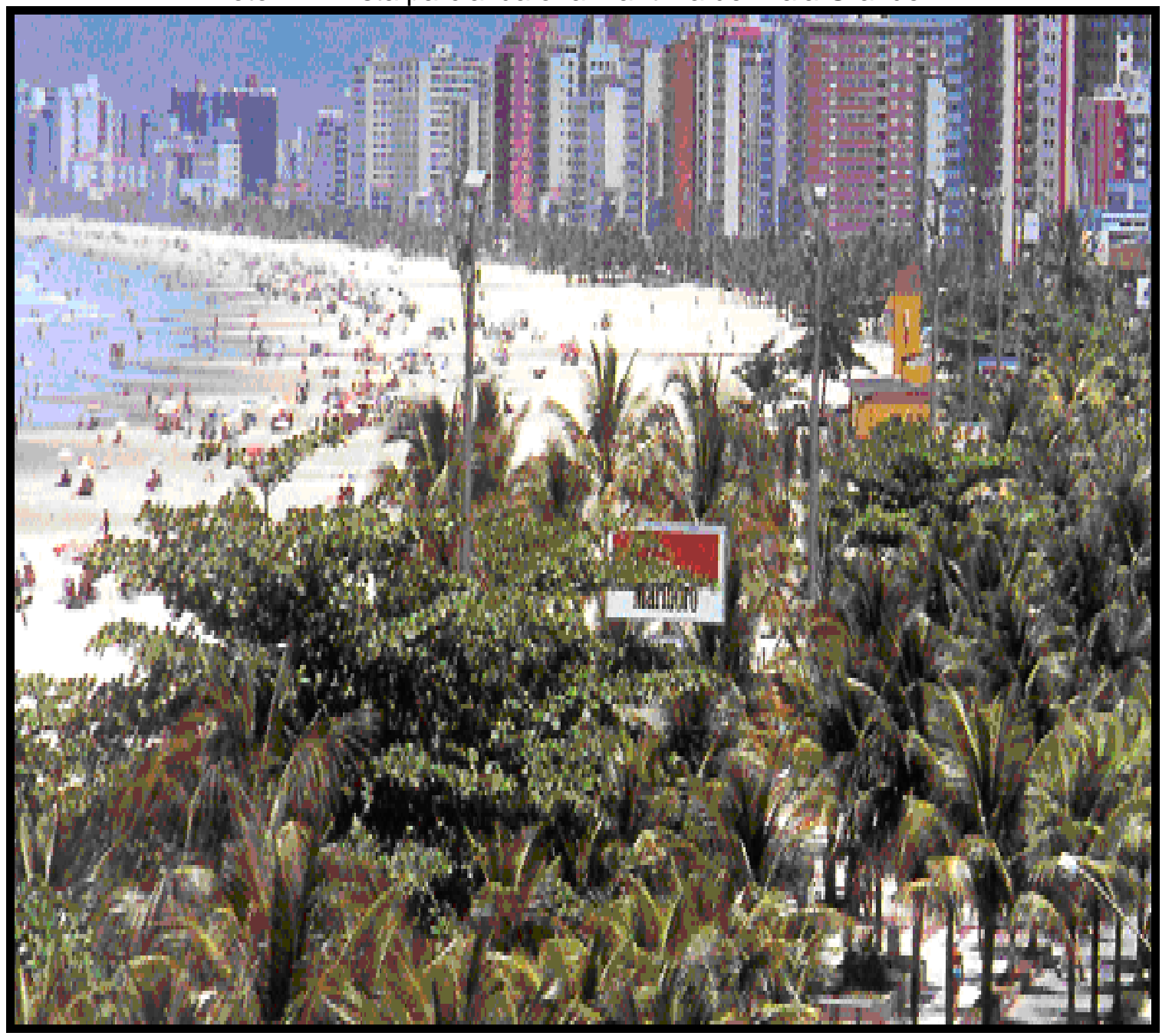

Fonte: Disponível em: http://www.agem.sp.gov.br/indicadores/default.htm, acesso em 02/02/2007, por Imário Vieira. Autor desconhecido

Nessa foto, temos uma vista parcial da orla marítima de Praia Grande que conta com 22,5 km de praias, cercada por inúmeros edifícios e milhares de coqueiros que dão um toque todo especial à cidade e que, embora esse balneário esteja bem urbanizado, os coqueiros e palmeiras dão um ar paradisíaco a essa estância balneária, com um espaço espetacularizado para atender aos turistas e moradores locais. 
Foto 42 - Calçadão e ciclovia em Praia Grande

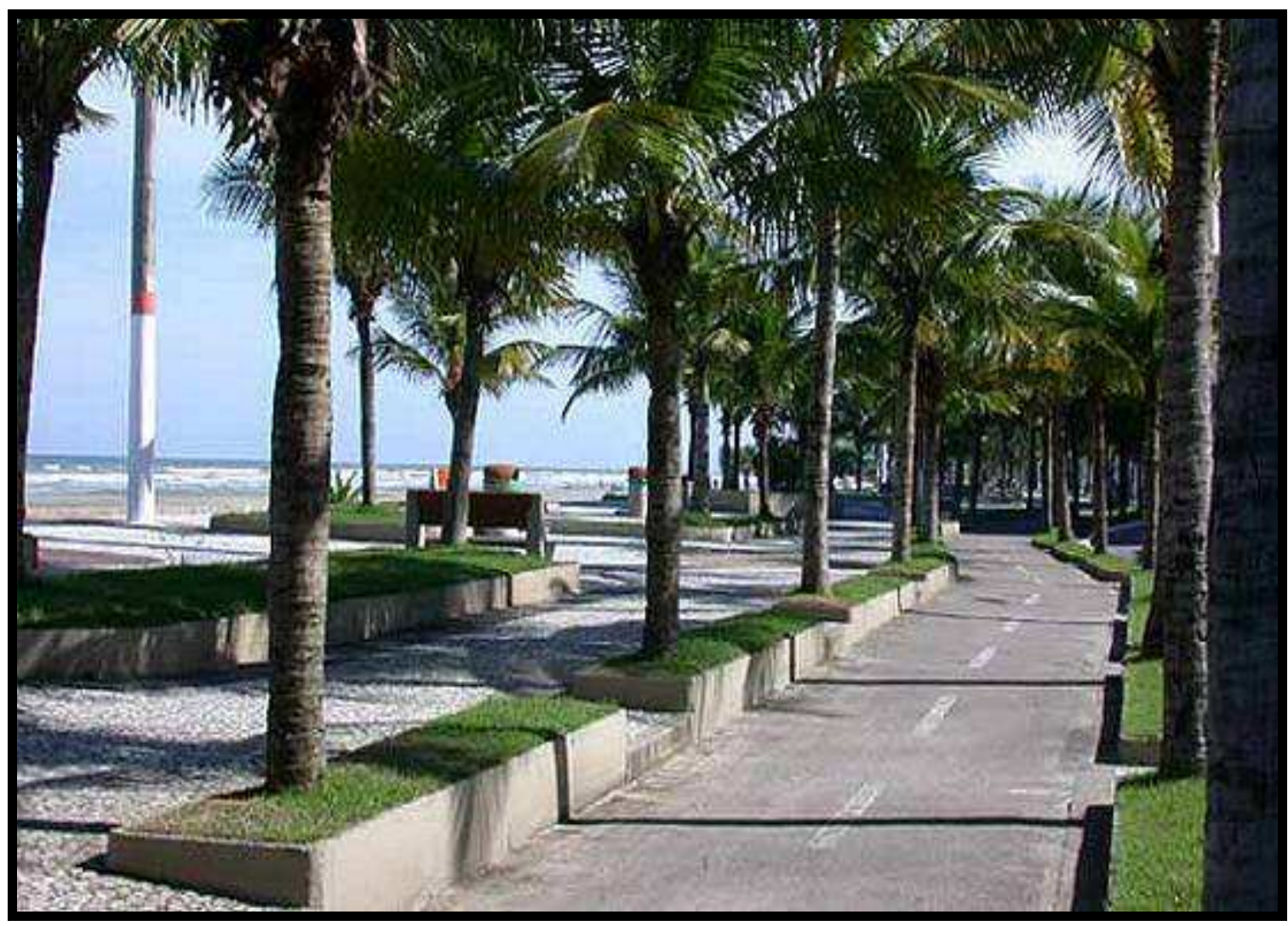

Fonte: Disponível em http://www.novomilenio.inf.br/pg/index.html, acesso em 03/02/2007 por imário Vieira. Autor desconhecido.

Essa foto mostra um pequeno trecho da orla de Praia Grande, com vista parcial do calçadão e ciclovia. O início da construção da ciclovia deu-se no princípio da década de 1990, especificamente em 1993, na primeira gestão do prefeito Alberto Pereira Mourão. O calçadão de Praia Grande é um dos mais longos calçadões à beira mar do litoral brasileiro. Nessa época, a Estância Balneária de Praia Grande passou por um grande processo de reurbanização em sua orla e adjacências, resgatando a qualidade de vida para seus moradores e turistas. Também data dessa época, o início da plantação de coqueiros em sua orla figurando no imaginário de seus moradores e visitantes, um paraíso tropical. Nos dias atuais, são mais de $50 \mathrm{Km}$ de ciclovias asfaltadas e sinalizadas, sendo 22,5Km à beira mar. 
Foto 43 - Quiosques modernizados

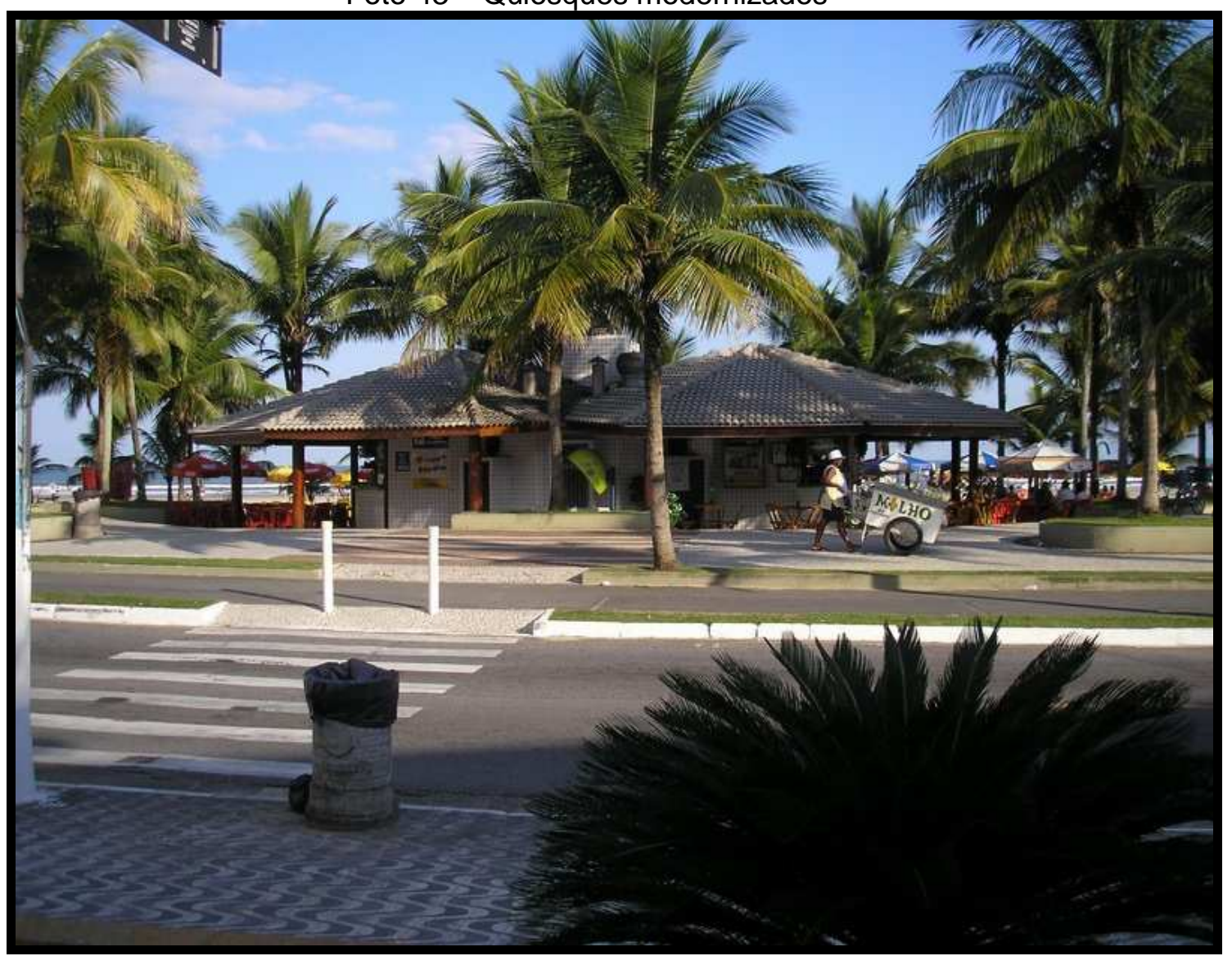

Fonte: Imário Vieira - Data: 18/11/2007 - Autor Imário Vieira

Os antigos quiosques de madeira foram substituídos por quiosques de alvenaria. Hoje, ao longo da orla da Estância Balneária de Praia Grande encontram-se 163 quiosques que oferecem bebidas e petiscos àqueles que os visitam, além das famosas "barraquinhas" que ficam nas areias de suas atuais 12 praias.

Há, ainda, a região do portinho com sua infra-estrutura turística (ver foto 45), Igrejas históricas como a Capela de Nossa Senhora da Guia, a de Vila Mathilde, Matriz de Santo Antonio, locais públicos destinados a práticas de halterofilismo, esportes como futebol e vôlei de areia, centros de convivência para a $3^{\underline{a}}$ idade, mesas de jogos, boutique dos peixes, um Shopping à beira-mar e outro na entrada do balneário. Isso sem falar da Avenida Costa e Silva que, após sua reurbanização e cobertura de grande parte de suas calçadas, transformou-se em um grande Shopping ao ar livre. Temos também feira de artesanato, restaurantes, churrascarias, sorveterias, supermercados, um Aero Clube, Pista de Skate Ocian, 
o Skate Park (no Bairro Aviação) com 960 metros quadrados no qual foram construídos oito diferentes tipos de obstáculos e uma mini-rampa com quase 1,6 metros de altura.

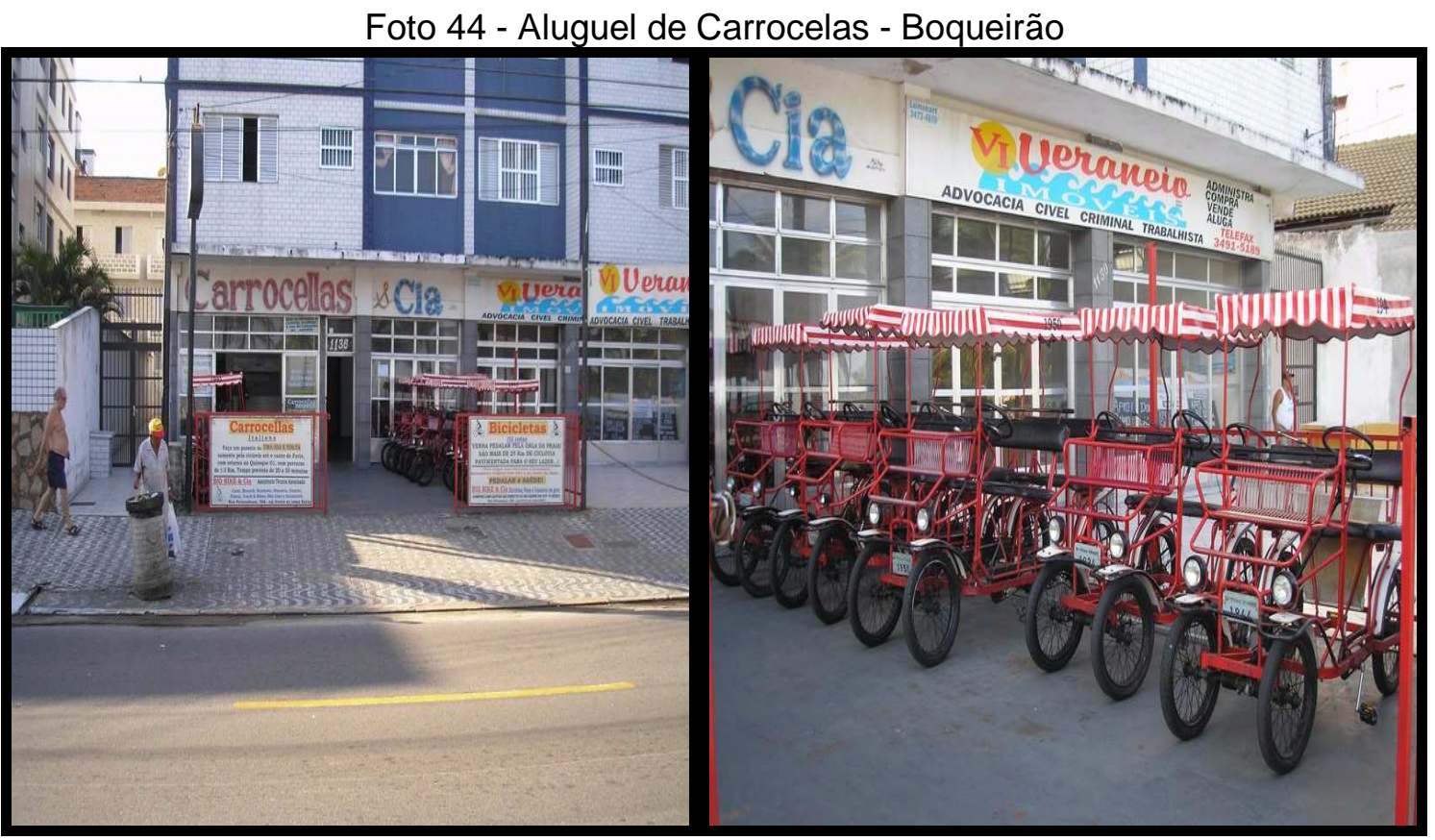

Fonte: Imário Vieira - Data: 26/01/2008 - Autor: Imário Vieira

No Bairro Boqueirão, os turistas e moradores locais podem desfrutar da bela paisagem da orla praiagrandense fazendo um passeio pela ciclovia de sua orla marítima alugando essas carrocelas.

A cidade conta, ainda, com lindas praças e monumentos como o de Netuno (no bairro Ocian - ver foto 46), a Estátua de lemanjá (na Praia Mirim), a Praça da Integração dos Bairros (no Bairro Tupy - ver foto 47), a Praça da Paz (no Bairro Boqueirão - ver foto 48) com cabeças esculpidas em metal de grandes celebridades do mundo, a Praça do Barquinho (no Jardim Guilhermina), a Praça Mamonas (homenagem ao Grupo Mamonas Assassinas - no Bairro Tupy) e outras espalhadas em pontos estratégicos do balneário. 
Foto 45 - Vista parcial da Área de Lazer Ézio Dall'Acqua (o Portinho)

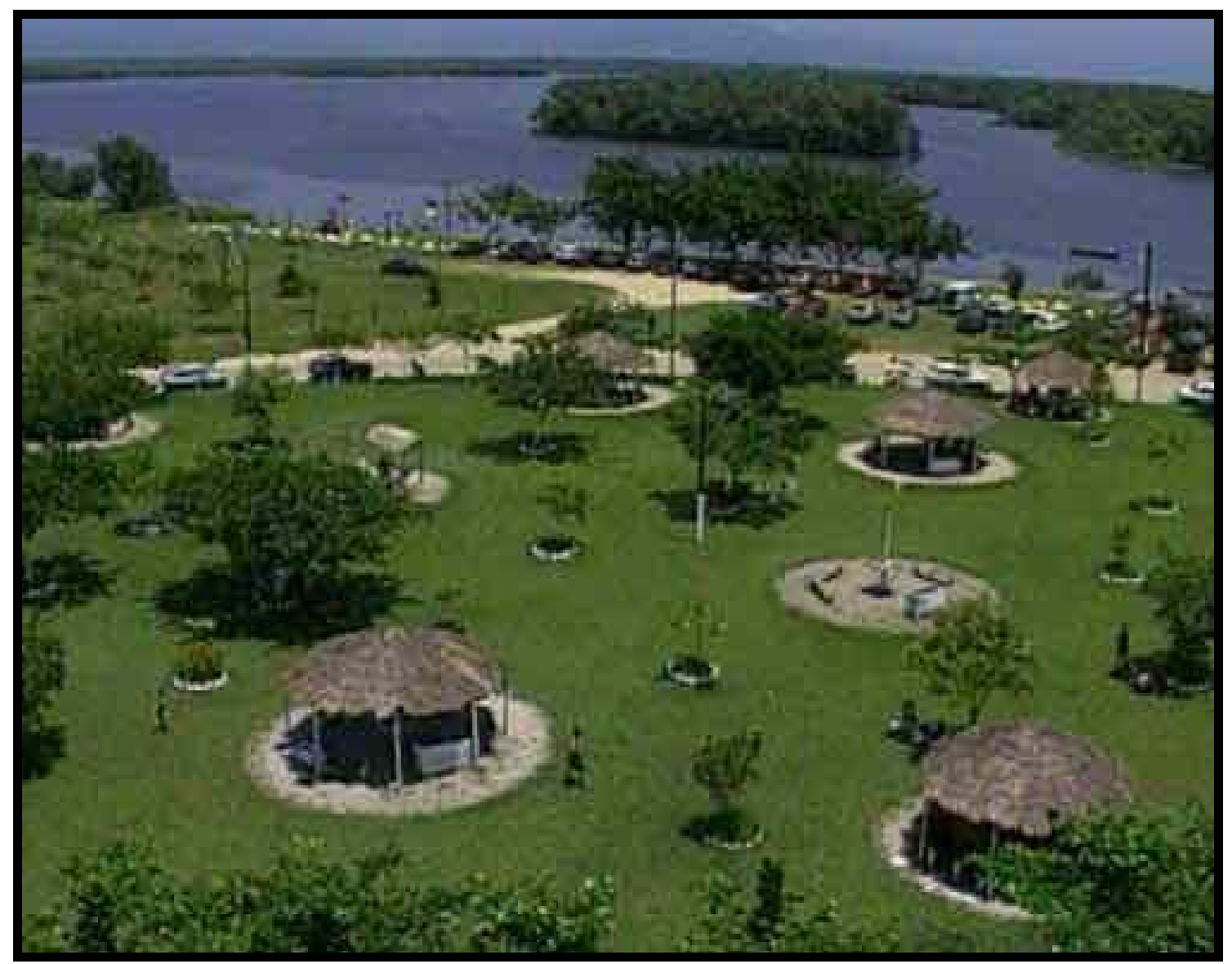

Fonte: disponível em: http://www.praiagrande.sp.gov.br, acesso em 05/02/2007, por Imário Vieira. Autor desconhecido.

A região do Portinho abriga uma extensa área verde com área para pescaria, píer, quiosques com churrasqueiras, estacionamento e campo de futebol. Os turistas e moradores que visitam essa atração turística em Praia Grande podem desfrutar de um ambiente muito agradável, além de uma bela paisagem. O píer tem 150 metros para que os visitantes possam desfrutar da pesca e conta com serviços de locação de barcos. Além de tudo isso, para aqueles que gostam de passeios de escuna, o visitante tem a oportunidade de conhecer várias atrações turísticas, tais como os manguezais, passar sob as pontes do Mar Pequeno e Pênsil, pela orla da Praia do Gonzaguinha e tem ainda a oportunidade de mergulhar na Praia de Paranapuã, no Parque Estadual Xixová-Japui. Este passeio de escuna tem a duração aproximada de uma hora e meia, ao custo de $R \$$ 15,00 . 
Foto 46 - Estátua de Netuno no Ocian

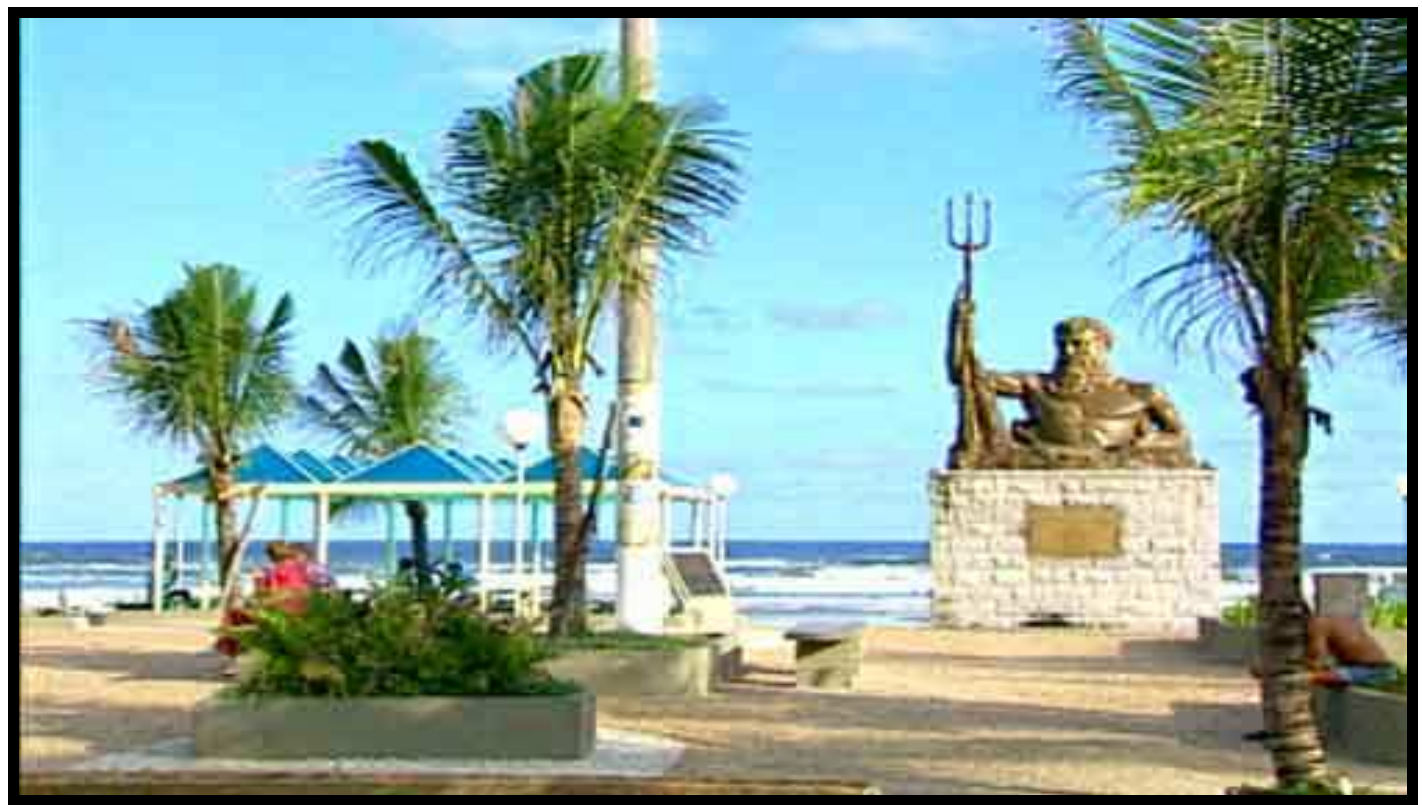

Fonte: disponível em: http://www.praiagrande.sp.gov.br, acesso em 05/02/2007, por Imário Vieira. Autor desconhecido

Essa estátua, construída em bronze, é um dos famosos cartões postais de Praia Grande e está situada à frente da orla da Praia de Ocian.

Foto 47 - Praça Integração dos Bairros, "Praça das Bolas" no bairro Tupi.

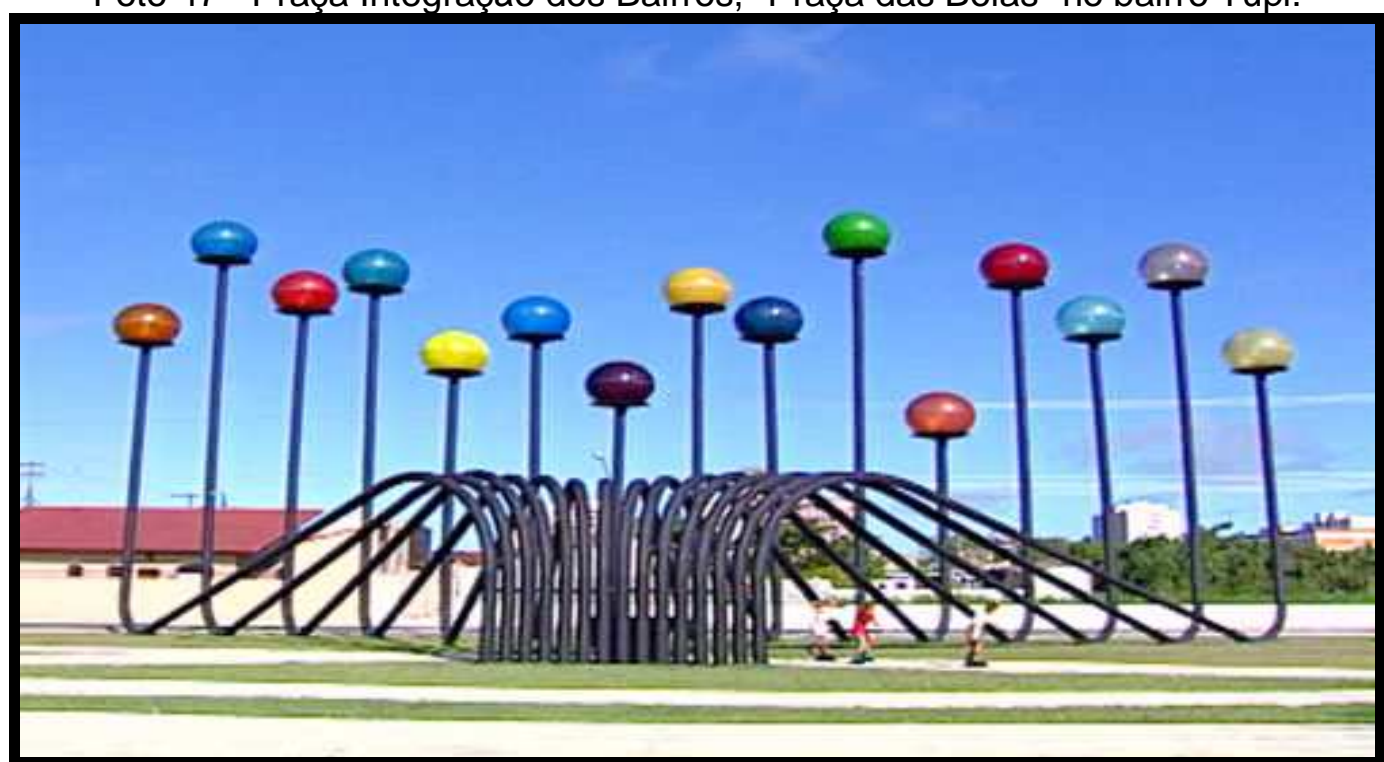

Fonte: disponível em: http://www.praiagrande.sp.gov.br, acesso em 05/02/2007, por Imário Vieira. Autor desconhecido

Essa praça segue um padrão bem modernista e chama a atenção de todos aqueles que a visitam ou passam por suas imediações. É conhecida pelas 15 bolas coloridas, que foram pintadas de acordo com o Projeto Rumo, que identifica os bairros de Praia Grande por cores, essas bolas recebem uma iluminação noturna especial. 
Foto 48 - Praça da Paz (das cabeças)

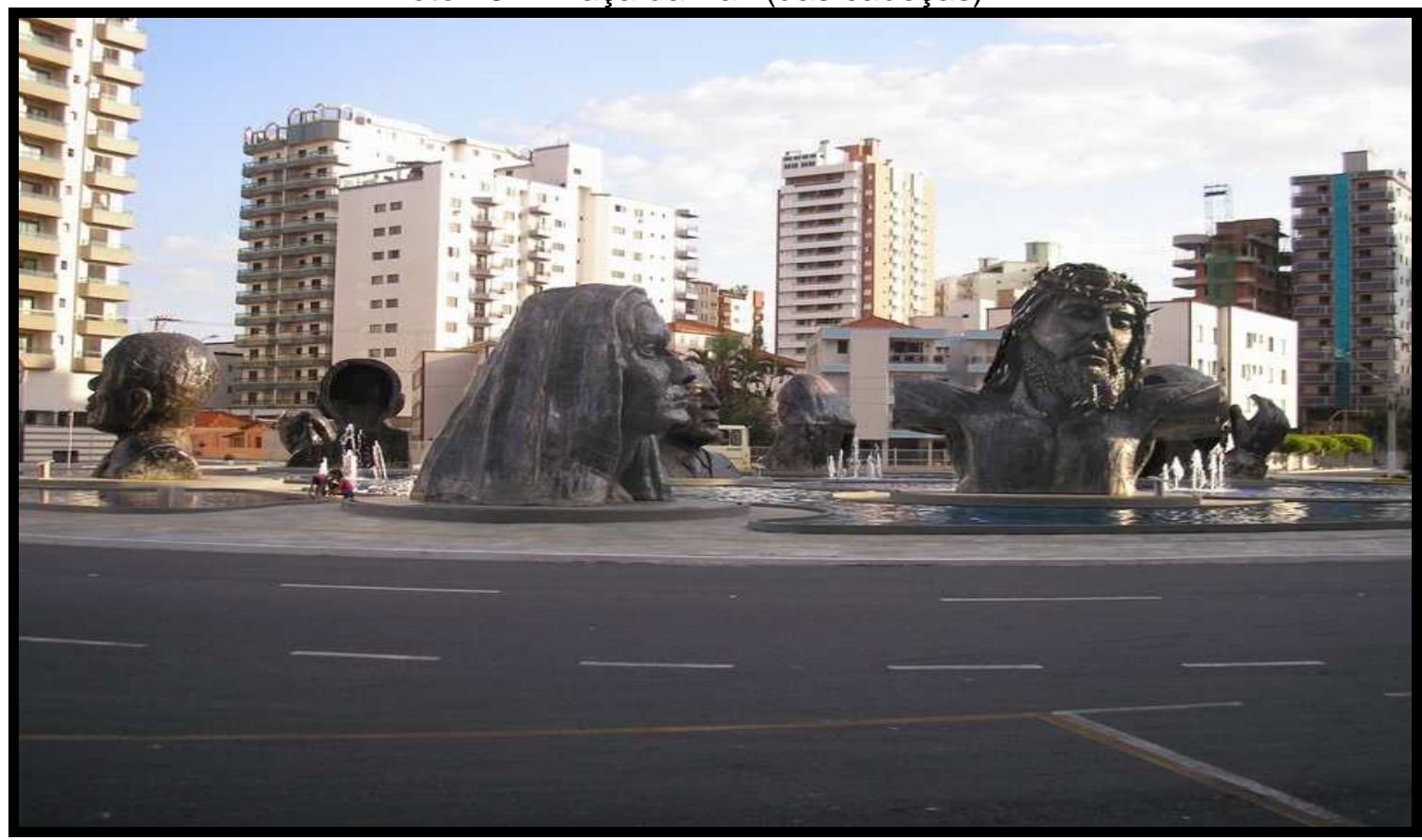

Fonte: Imário Vieira - Data: 22/12/2007 - Autor: Imário Vieira

Localizada no cruzamento das Avenidas Brasil e São Paulo, essa praça, "A Praça da Paz", possui sete cabeças de tamanho gigante, feitas de aço carbono e ferro. Os bustos são de autoria do escultor Gilmar Pinna e representam personalidades que defenderam a paz no mundo, são elas: Jesus Cristo, Maria Mãe de Jesus, Papa João Paulo II, Madre Tereza de Calcutá, Mahatma Gandhi, Nélson Mandela e Sérgio Vieira de Mello.

E em breve, este balneário, também contará com um novo espaço destinado à cultura, "o Palácio das Artes", próximo ao Terminal Tude Bastos. Em relação a isso, O Jornal DCl (DCl, São Paulo, 21, 22, 23 out. 2006. Caderno C. C1 p.) comenta:

"Com um investimento de $\mathrm{R} \$ 2$ milhões, está em obras a construção do Palácio das artes, voltado integralmente à cultura. Localizado na Avenida Costa e Silva, no Bairro Boqueirão, o espaço de 6,2 mil metros quadrados terá teatro para 630 espectadores, centro de documentação e museu municipal, área para exposição e eventos, e instalação do Programa de Ação e Cidadania e da sede da Secretaria de Cultura e Eventos.

Este Palácio das Artes tem sua entrega prevista para o primeiro semestre de 2008 e marcará a história da cidade, pois a partir de sua entrega, terá um museu e um espaço dedicado à cultura. 
Os outros atrativos que o município dispõe são: visitação a um de seus belos patrimônios naturais, o Morro do Xixová/Japuí ${ }^{69}$, que está à beira-mar, numa área de reserva da mata atlântica, com seus 320 metros de altura acima do nível do mar, de onde pode ser avistada toda a Baixada Santista. É em meio a essa paisagem natural que se encontra a Fortaleza de Itaipu ${ }^{70}$, que abriga em seu interior três fortificações a saber: o Forte Jurubatuba, o Forte Duque de Caxias e Forte General Rego Barros. A Fortaleza do Itaipu foi aberta à visitação pública em 1996. No passeio, os turistas têm a oportunidade de visitar antigos armamentos de guerra e algumas de suas dependências. Nos dias atuais, dos três fortes mencionados, apenas um deles, o Forte Jurubatuba, está aberto à visitação pública.

Um outro atrativo é o Parque Estadual da Serra do Mar $^{71}$ que, entre suas belas paisagens naturais, tem uma cachoeira conhecida como a Cachoeira do Jardim Melvi, com várias quedas e uma piscina natural. Praia Grande tem ainda um outro parque, o do Peacabuçu ${ }^{72}$.

Com tantos patrimônios naturais, Praia Grande tende a beneficiar-se bastante com o turismo ecológico, pois tem muitas regiões com espaços naturais, com belas áreas preservadas como os mangues, a restinga, as várzeas dos rios Preto e Branco e parques tombados para preservação das riquezas naturais desta cidade média do estado de São Paulo.

Ao falar do crescimento do turismo em áreas naturais, Cruz (2003, p. 17) diz que "foi fundamentalmente, na década de 1990 que modalidades de turismo relacionadas a espaços naturais cresceram em importância no conjunto dos segmentos das viagens turísticas". Dentro deste contexto elucidado pela autora, Praia Grande tende a beneficiar-se bastante, pois tem muitas regiões com

${ }^{69}$ Criado pelo Decreto Estadual 37.536/93: De acordo com site da prefeitura de Praia Grande (Disponível em http://www.praiagrande.sp.gov.br. Acesso em 02/02/2007 por Imário Vieira) este parque ocupa 5,54 $\mathrm{Km}^{2}$, totalizando $2,10 \%$ da área de Praia Grande.

${ }^{70}$ Itaipu, na lingual tupi, quer dizer "pedra das águas roncadoras".

${ }^{71}$ Criado pelo Decreto Estadual 10.251/77 e 13.313/79: : De acordo com site da prefeitura de Praia Grande (Disponível em http://www.praiagrande.sp.gov.br. Acesso em 02/02/2007 por Imário Vieira) ele ocupa $45,31 \mathrm{Km}^{2}$, totalizando $31,25 \%$ da área de Praia Grande.

72 De acordo com site da prefeitura de Praia Grande (Disponível em http://www.praiagrande.sp.gov.br. Acesso em 02/02/2007 por Imário Vieira) este parque ocupa $8,54 \mathrm{Km}^{2}$, totalizando $5,9 \%$ da área de Praia Grande. 
espaços naturais. Até cursos foram criados pelo Departamento da Cultura desta estância balneária para promover esses lugares para os moradores e àqueles que visitam a Escola de Educação Ambiental na região do Portinho, em Praia Grande.

Cabe-se lembrar, para os amantes da pesca, que o balneário é banhado por nove rios e são eles: Rio Branco, Rio Negro, Rio Guaramar, Rio Piacabuçu ou Peacabuçu, Rio Boturoca, Rio da Cruz ou das Cruzes, Rio Acaraú, Rio Itinga e Rio das Cobras. Um outro ótimo local para pesca, além do Portinho e dos rios, é o pesqueiro do "Casco do Navio", o qual o pescador fica exatamente no casco de um navio naufragado há muitos anos atrás e que está encalhado próximo à praia.

Vale ressaltar que, entre suas outras atrações turísticas, temos a Festa de lemanjá, um evento religioso que consegue atrair milhares de pessoas às suas praias. Trata-se de uma festa religiosa e de evocação dos orixás pedindo aconselhamento e bênçãos para o ano que se inicia.

Além da Festa de lemanjá, não podemos esquecer da Festa da Passagem de Ano, com seus Shows Pirotécnicos que, também, atraem centenas de milhares de pessoas em toda sua orla marítima para ver o espetáculo nos céus da cidade. $\mathrm{Na}$ passagem de ano de 2005 para 2006, por exemplo, incrementaram o espetáculo com barcaças que ficaram a uns cinqüenta metros da praia com algumas toneladas de fogos de artifício. Os fogos de artifício dessas barcaças geraram um espetáculo de quase 15 minutos e que pôde ser visto a quilômetros de distância do local e por todos os que estavam presentes em sua extensa orla marítima. Também, durante o verão, a prefeitura dessa cidade-média, realiza muitos Shows com artistas famosos durante quase um mês seguido (veja foto 49) atraindo um grande número de turistas à Praia Grande. 
Foto 49 - Show de verão em Praia Grande

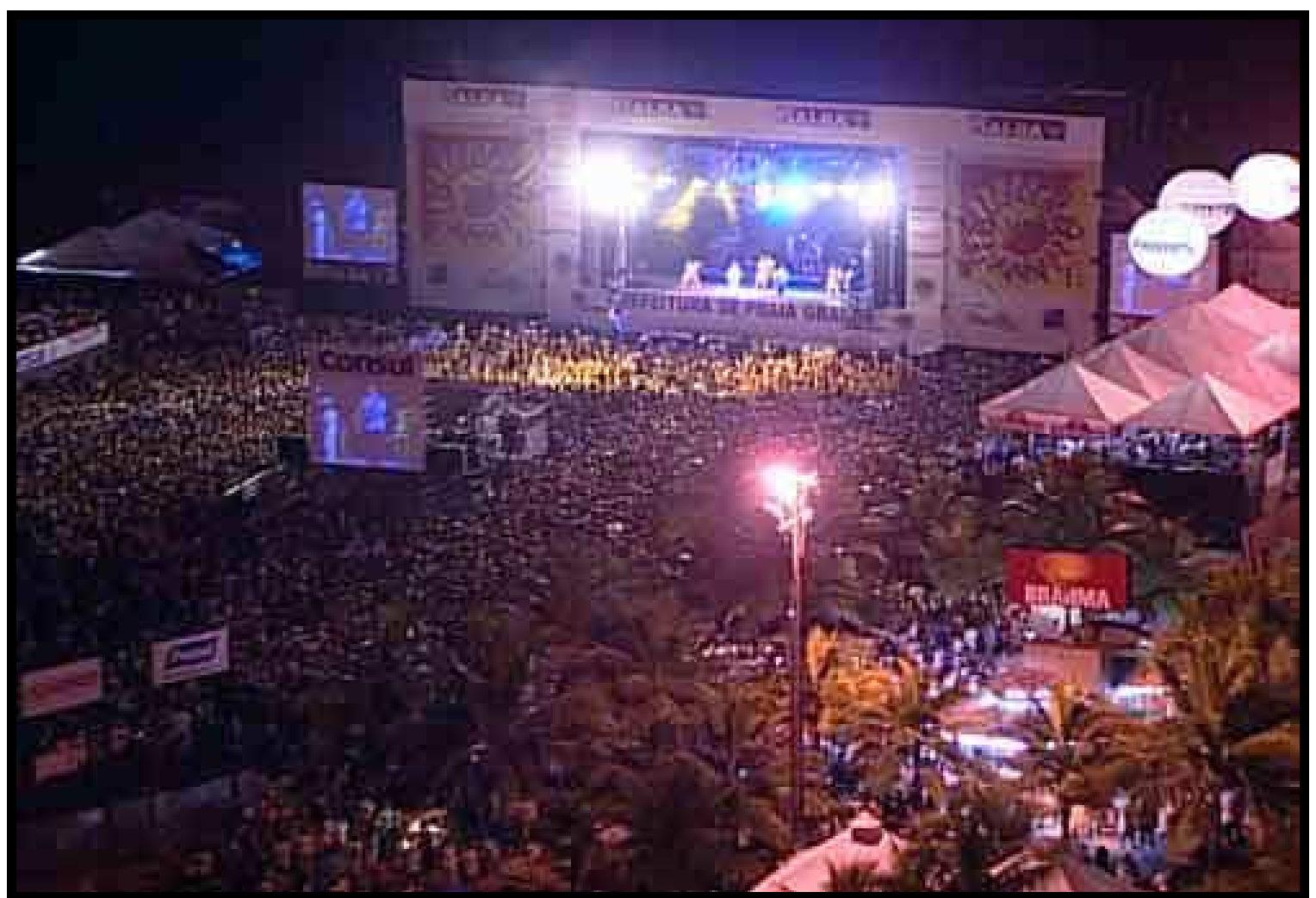

Fonte: disponível em: http://www.praiagrande.sp.gov.br, acesso em 05/02/2007, por Imário Vieira. Autor desconhecido

O projeto intitulado como "O Show do Verão é Você", em sua 16"a edição nesse ano de 2008, já virou um atrativo turístico e parte do calendário da cidade. Os shows acontecem na praia da Aviação e têm início por volta das 22 horas. O evento que neste ano de 2008, foi do dia 04 ao dia 26 de janeiro, é aberto ao público em geral, mas disponibiliza a venda de cadeiras numeradas e arquibancadas, com renda revertida para o fundo de solidariedade da cidade de Praia Grande. É sempre realizado no mês de Janeiro, pois é o mês de aniversário da cidade e coincidentemente tem o seu final próximo ao aniversário e feriado prolongado da metrópole de São Paulo.

A Praia Grande possui uma Casa da Cultura, onde são oferecidos cursos de trabalhos manuais e artesanato de um modo geral. A mesma também tem uma coordenadoria que oferece cursos sobre o meio-ambiente e eco-turismo.

Aos finais de semana, nos calçadões da praia, nas proximidades do centro, a cidade conta com exposição e venda de quadros de artistas locais, para os mais variados gostos.

Está em sua agenda, para projetos futuros, a recuperação das antigas e desativadas estações de trem da Fepasa para um projeto turístico envolvendo um 
passeio com locomotiva do tipo Maria Fumaça entre as três cidades: Praia Grande, Mongaguá e Itanhaém. Esta linha de Maria Fumaça poderá ter 50 km de extensão, saindo de Praia Grande (estação Vila Caiçara) e chegando em Itanhaém, no Bairro Belas Artes. Esse projeto tem em seu escopo paradas nas estações existentes nas três cidades, onde haveria atrações como artesanato, música e com comidas típicas que seriam oferecidas aos turistas a preços convidativos.

Segundo informações obtidas no Departamento de Imprensa e de Planejamento Urbano da Estância Balneária de Praia Grande, o turismo, é a segunda atividade mais importante da cidade, perdendo apenas para o setor de construção civil que está ligado ao turismo de segunda residência.

Muito tem sido feito para melhorar a infra-estrutura hoteleira da cidade que, nos dias atuais, tem um quadro bem diferente daquele que se apresentava na metade do século passado. Ao falar dessa época, Magalhães (1965, p. 73) comenta: "notável ainda é a quase ausência de hotéis. Ao todo só nos foi possível localizar três, dois no Boqueirão, de nível médio inferior, e um de nível médio, entre o Boqueirão e Cidade Ocian".

De acordo com a última pesquisa feita pela EMPLASA (2001), e dados da Secretaria do Turismo da Estância Balneária de Praia Grande (2008), a infraestrutura hoteleira de Praia Grande é a seguinte:

Tabela 06 - Infra-estrutura Hoteleira da Praia Grande de 2001/2008

\begin{tabular}{|l|c|c|}
\hline \multicolumn{1}{|c|}{ Hospedagem } & $\begin{array}{c}\text { Número de } \\
\text { unidades em } \\
\mathbf{2 0 0 1}\end{array}$ & $\begin{array}{c}\text { Número de } \\
\text { unidades em } \\
\mathbf{2 0 0 8}\end{array}$ \\
\hline Albergue & 0 & 0 \\
\hline Colônia de Férias & 57 & 62 \\
\hline Camping & 0 & 0 \\
\hline Flat & 1 & 1 \\
\hline Hotel & 12 & 20 \\
\hline Motel & 15 & 18 \\
\hline Pensão / Pousada & 6 & 12 \\
\hline Total & 91 & 113 \\
\hline
\end{tabular}

Fonte: EMPLASA, 2001. Secretaria do Turismo de Praia Grande, 2008. 
Elaborado por: Imário Vieira

Esses números só reforçam a importância de Praia Grande, principalmente no que se refere às Colônias de Férias, que neste balneário, tem presença marcante com suas atuais 62 colônias e com um aumento de 22 estabelecimentos em relação aos 91 registrados em 2001. No entanto, cabe-se ressaltar que, Praia Grande tem muitos projetos que buscam ampliar ainda mais sua parcela de participação no segmento do turismo.

Um outro tipo de turismo em expansão em Praia Grande é o turismo de eventos. Em relação a isso, Cruz (2003, p. 49) relata:

"Vimos assistindo nos últimos anos ao crescente aumento, em importância, tanto para o setor de turismo de modo geral como para a hotelaria, especificamente das estruturas relacionadas à realização de eventos".

$\mathrm{Na}$ área do Turismo de Negócios e Eventos, a cidade sediou no ano de 2006, um dos encontros dos Municípios do Estado de São Paulo. Esse evento trouxe um grande fluxo de pessoas que lotaram seus hotéis, pousadas e colônias de férias da cidade. Ações públicas têm sido tomadas de modo a aumentar o fluxo de turistas de outros segmentos, como, por exemplo, ecoturismo, o turismo de negócios e eventos dos mais variados pólos emissores para esse balneário.

Apenas no final de 2005, com a criação e separação da Secretaria do Turismo da Secretaria do Desenvolvimento, que se pretendeu aprimorar a infraestrutura da cidade de Praia Grande e incentivar ainda mais o turismo dessa estância balneária, pois é bem sabido que o turista, em sua grande maioria, ao sair de sua cidade, busca, em seus destinos turísticos, condições e infra-estrutura similares àquelas que estão habituados no seu local de residência fixa. A respeito disso, Sanchez (1991, p. 234) nos relata:

"Não devemos ignorar que na maioria dos casos, o turista é um 'urbanita' que espera encontrar algo similar ao que dispõe no seu lugar 
de residência habitual (tipo de comida inclusa), mas um espaço de ócio-Sol-praia (...). A nível municipal, todas estas transformações incidirão não somente sobre o território municipal, como também sobre a própria vida dos povos e sobre a especialização funcional de suas atividades produtivas ". ${ }^{73}$

Estas transformações que são implementadas e que visam dotar um lugar turístico de todas as condições e infra-estruturas existentes nos grandes centros urbanos afetam não só a especialização de atividades produtivas dos seus receptores, mas, também, a vida de seus moradores fixos.

Nas décadas de 1970 e 1980, Praia Grande ficou cognominada como praia dos pobres, de turistas de um dia, praias de farofeiros, praias sujas e poluídas etc. Devido a isso, desde a década de 1990, como já mencionado nesse capítulo, e sob a administração do prefeito Alberto Pereira Mourão, a administração pública da cidade vem intervindo de forma decisiva, visando resgatar o glamour da cidade como estância balneária, com sérias mudanças em quase toda a cidade e transformando, de forma significativa, a sua paisagem.

Em relação ao turismo, o atual prefeito, Sr. Alberto Pereira Mourão, de acordo com entrevista ao jornal DCl (DCl, São Paulo, 21, 22, 23 out. 2006. Caderno C. C-1 p.) em final de 2006, diz:

"Para incrementar o turismo várias obras estão em andamento em Praia Grande. Segundo o prefeito (...) a principal obra é a construção do $3^{\circ}$ emissário submarino e 207 quilômetros de rede de esgotos, feito pela SABESP, num investimento de cerca de $R \$ 150$ milhões, com recursos do Japan Bank for International Cooperation (J BIC), ligado ao governo japonês".

${ }^{73} \mathrm{O}$ texto em espanhol diz:

"No debemos ignorar que en la mayoria de los casos, el turista es un 'urbanita' que espera encontrar algo similar a lo que dispone en su lugar de residencia habitual (tipo de comida incluido), mas un espacio de ocioSol-playa.(...). A nivel municipal, todas estas transformaciones incidirán, no solamente sobre el territorio municipal, sino también sobre la propria vida de los pueblos y sobre la especialización funcional de sus actividades productivas". 
Além desses investimentos na área de saneamento e despoluição das praias, Praia Grande conta hoje com vários projetos para o futuro na área de empreendimentos turísticos, entre eles temos: "Duna Water Park” (ver figura 19), com previsão de utilização de uma área de $42 \mathrm{mil} \mathrm{m}^{2}$, cercada por piscinas, lagos e riachos. Esse parque, se contar com os investimentos da iniciativa privada, será um espaço turístico repleto de toboáguas, playgrounds, estacionamentos, lojas de souvenirs, lanchonetes, e tantos outros atrativos e ainda com uma localização privilegiada, ou seja, de frente para o mar.

Figura 19 - Projeto Duna Water Park

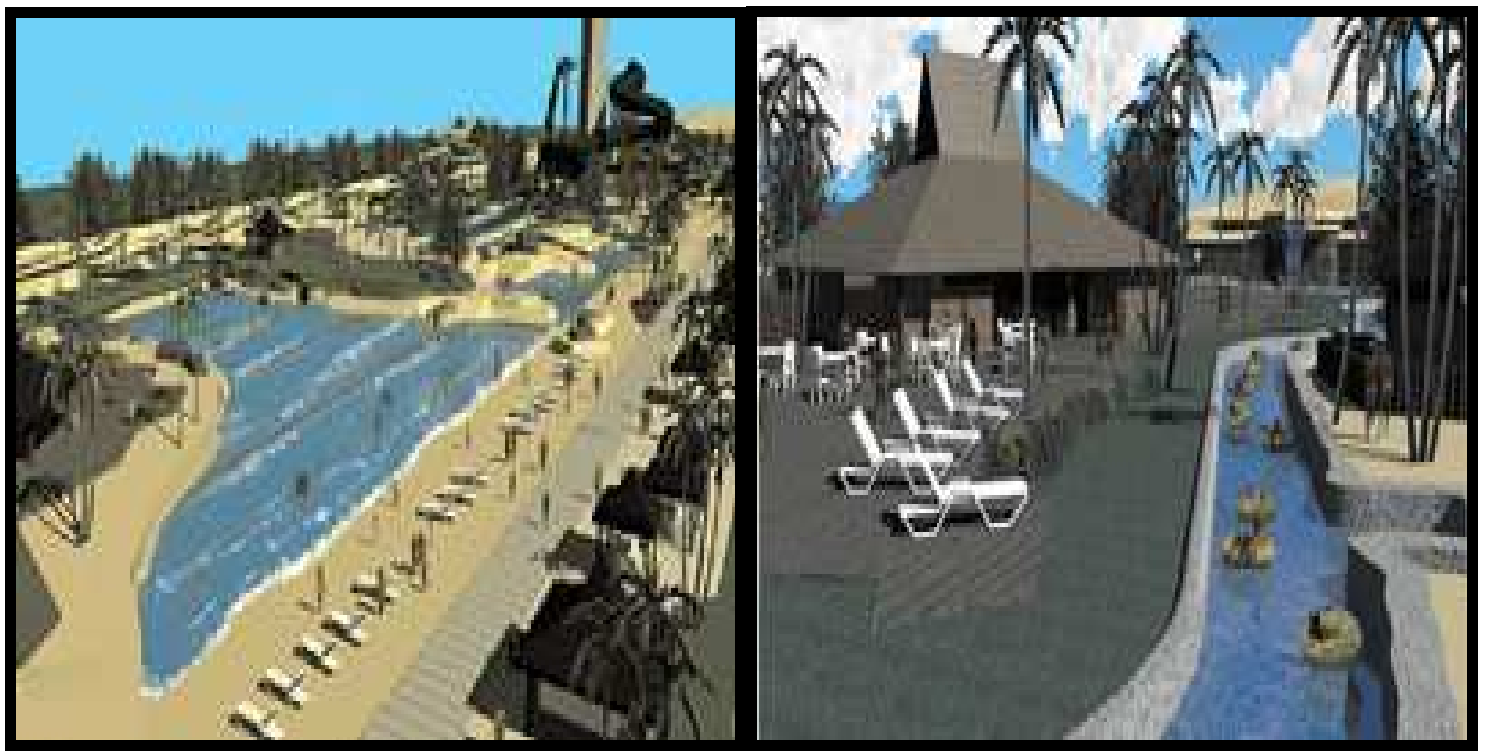

Fonte: Disponível em: http://www.praiagrande.sp.gov.br/ , acesso em 20/01/2008, por Imário Vieira

Segundo o site da prefeitura da Estância Balneária de Praia Grande nos informa (Disponível em: http://www.praiagrande.sp.gov.br/, acesso em 20/01/2008, por Imário Vieira) são inúmeros os projetos e plantas e com grandes áreas que já estão disponíveis e só estão aguardando parceiros da iniciativa privada, O Duna Water Park, é um deles. Esse parque contará com uma área de $42 \mathrm{mil} \mathrm{m}^{2}$, de frente para o mar e que incluem: piscinas, lagos, riachos, dunas, toboáguas, bares, lanchonetes, playgrounds, estacionamentos e utilizará uma área de 42 mil $\mathrm{m}^{2} \mathrm{com}$ toda a infra-estrutura de um parque desse porte. 
A cidade também tem projetos para a modernização da área do Portinho, intitulado como o projeto "Multiplace Portinho" e que, se colocado em prática, a sua área atual abrigará um dos mais modernos, aconchegantes, seguros e belos espaços para shows e lazer do país, cotando com bar flutuante, boate com fontes luminosas etc. Conta ainda com um projeto que visa construir uma plataforma de pesca e de passeio junto ao morro do Itaipu, o que permitirá aos turistas e moradores apreciar uma paisagem imperdível de sua orla, que será vista de um ponto estratégico de Praia Grande, em uma plataforma que irá até o extremo do morro junto ao alto mar. Enfim, a cidade conta com vários outros projetos que visam ampliar e fortalecer o turismo nessa cidade litorânea, sendo que muitos já intitulam Praia Grande como: "A Princesinha da Mata Atlântica". 


\section{CONSIDERAÇÕES FINAIS}

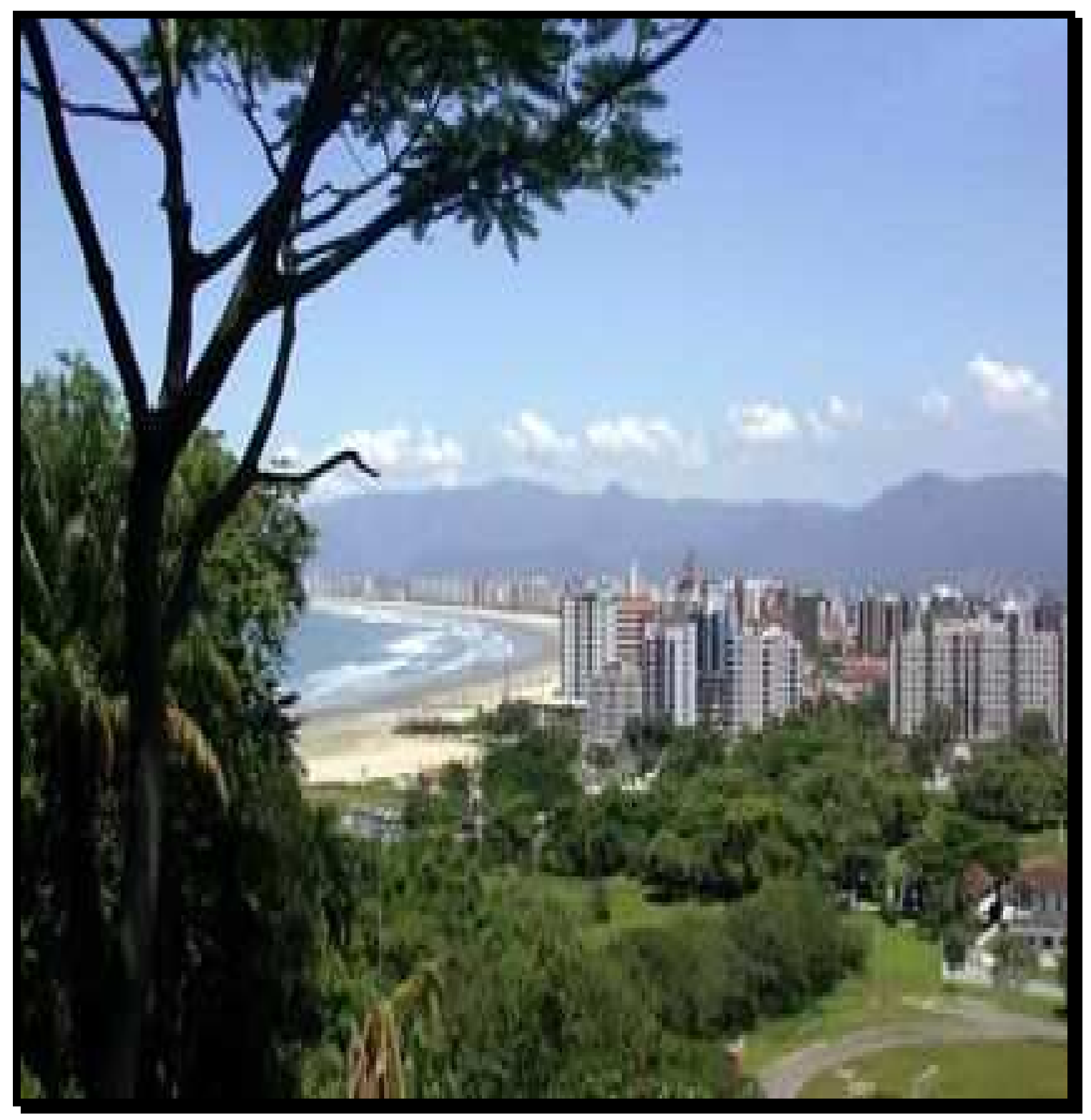


Nosso trabalho de pesquisa teve como objetivo analisar o processo histórico da urbanização de Praia Grande, desde a época em que ainda fazia parte da cidade de São Vicente, buscando entender como se deu a produção do espaço amparada pelo turismo de segunda residência, compreendendo sua relação com a metrópole de São Paulo e os motivos pelos quais o turismo de segunda residência, em Praia Grande, tornou-se acessível aos turistas.

$\mathrm{Na}$ primeira parte deste trabalho de pesquisa, constatamos que o processo de urbanização em São Vicente, município ao qual Praia Grande pertenceu até 1967, começou no início do século XVI, logo após a colonização do nosso país, quando Martim Affonso de Souza fez demarcações de terras, loteou, colocou em prática o processo de arruamento e distribuição de lotes aos sesmeiros da então Vila de São Vicente.

Esse processo de urbanização, iniciado por Martim Affonso há muito tempo atrás, foi intensificado na região em que hoje se encontra a atual Estância Balneária de Praia Grande e que, por muito tempo, serviu como elo de ligação entre o planalto paulista e Itanhaém, propiciando um primeiro processo de ocupação da região praiagrandense.

No entanto, o início da construção da Fortaleza do Itaipu, em 1902, e a inauguração da Ponte Pênsil, em 1914, foram sem dúvida alguma, marcos históricos para o crescimento urbano de Praia Grande, pois, com essas construções, o acesso foi grandemente facilitado com sua sede em São Vicente e outras cidades. Assim, as facilidades de acesso foram gerando uma série de mudanças que, aos poucos, foram transformando a paisagem natural desse balneário.

Não seria necessária pesquisa alguma para saber que, há muito tempo, desde a introdução do turismo litorâneo no Brasil, a área da atual Região Metropolitana da Baixada Santista (RMBS) esteve inserida no contexto do turismo da Metrópole de São Paulo e adjacências. Cabe-se ressaltar que essa ligação com a metrópole está, e sempre esteve presente, desde os primórdios da colonização do Brasil, quando ainda se utilizavam estreitas picadas indígenas como meios de comunicação entre o litoral e o Planalto Paulista. É claro que com o passar dos tempos, especificamente a partir do surgimento do turismo litorâneo 
no Brasil, com as melhorias das estradas que existiam, com construções de novas e modernas rodovias nos dias atuais, melhorias das condições de vida das populações do planalto, implantação de pólos industriais, desenvolvimento de sua economia e motorização familiar, esta ligação com a metrópole se estreitou ainda mais e para além das ligações porto-cidade dos tempos de outrora.

No princípio do século XIX, o turismo em Santos e São Vicente já era bem intenso, com a inauguração da Ponte Pênsil e com uma estrada ligando São Vicente a Fortaleza do Itaipu, o acesso às praias daquele distrito de São Vicente foi muito facilitado, trazendo grandes quantidades de pessoas que visitavam suas praias e se maravilhavam com as belezas naturais da região. Assim, junto com esses objetos técnicos que foram criados, vieram também a exploração imobiliária ligada ao turismo de segunda residência e, daí por diante, Praia Grande nunca mais parou de crescer e se desenvolver.

O caso Praia Grande é um exemplo típico de um simples distrito de uma cidade litorânea que, no princípio do século passado, ao despertar o interesse de seus visitantes por suas belas paisagens e praias, além de pouco habitadas, dá início a uma crescente exploração imobiliária por meio do turismo de segunda residência. Dessa forma, a exploração imobiliária neste balneário cresceu explorando as segundas residências como forma de ganhos fáceis e influenciada pelas belas paisagens, clima agradável, viagem de curta duração e lindas e extensas praias de sua região. Esses fatores fizeram com que a segunda residência fosse um objeto de desejo para as classes sociais que têm condições de realizar tal sonho, o de se obter uma residência de uso ocasional e, com isso, contribuiu decisivamente para estimular a especulação imobiliária pelos construtores e agentes imobiliários dos tempos mais remotos e atuais.

No entanto, do início do século XX para cá, quando ainda tinha sua atividade econômica ligada ao setor primário, esta região de São Vicente direcionou esforços para uma melhoria contínua de sua infra-estrutura básica, serviços de apoio e equipamentos existentes em sua região de modo a satisfazer os turistas e os moradores locais. Assim, devido a esse fluxo de turistas que para lá se dirigiam em busca de seu clima agradável e de suas longas e belas praias, deu-se início, a partir do final da década de 1920, a um processo de 
transformação do espaço por meio da exploração imobiliária voltada para o turismo de segunda residência que perdura até os dias atuais.

No capítulo dois, discutimos as origens do turismo no mundo, do banho de mar e como o turismo surgiu em Praia Grande. Verificamos que a inauguração do Hotel dos Alemães, em 1928, teve uma pequena parcela de participação no processo de ocupação mais recente de Praia Grande, uma vez que o mesmo localizava-se dentro de um dos primeiros loteamentos da região, o loteamento do Jardim Guilhermina.

Ficou claro por meio de nossas pesquisas que houve um processo de urbanização crescente a partir do início da construção de alguns objetos técnicos, tais como: a Fortaleza do Itaipu em 1902, a construção da Estrada de Ferro Santos-Juquiá a partir de 1912 e a entrega da Ponte Pênsil em 1914. Em tempos mais recentes (a partir do início da década de 1980), temos, ainda, a entrega de alguns objetos técnicos (pontes como a do Mar do Pequeno e outras), o que de certa forma, facilitaram os meios de comunicação entre a cidade e às Rodovias Anchieta e dos Imigrantes.

Evidenciamos o papel da Cia Territorial Jardim Guilhermina, como uma das primeiras empresas no ramo da exploração imobiliária no balneário de Praia Grande.

Na segunda metade da década de 1930, com a construção e inauguração do Aeroclube, na atual região do bairro da Aviação, por alguns empresários da cidade de Santos, a freqüência à região de Praia Grande aumentou consideravelmente, pois tratou-se de mais um atrativo para este distrito vicentino.

Verificamos que, na década de 1940, com o aprimoramento do sistema viário e de transporte, foi introduzida em Praia Grande uma nova forma urbana, ou seja, o processo de verticalização do balneário. No entanto, seu início se deu com a introdução de prédios de, no máximo, quatro andares, bem diferentes de São Vicente e da cidade de Santos que, na época, já sofriam um intenso processo de verticalização.

Dentro deste contexto, Souza (1989, p. 118-119) nos diz que a verticalização coloca-se como um divisor social do espaço, pois à medida que os edifícios vão sendo erguidos, certos bairros são valorizados devido à promoção da 
renovação urbana. Assim, o processo de verticalização, resultante da exploração imobiliária, vai concretizando um forte processo de segregação espacial que está diretamente ligado à concentração de renda dos detentores dos melhores lugares junto à orla das praias.

Desse modo, constatamos que, na metade do século passado, o processo de urbanização de Praia Grande, que na época ainda era um distrito de São Vicente, limitava-se às áreas próximas à sua orla marítima.

Cabe-se ressaltar que, ainda nessa época, os turistas da metrópole de São Paulo que quisessem chegar à Praia Grande tinham que passar por Santos e São Vicente, pois o único acesso que aquele distrito de São Vicente tinha com as regiões do planalto era por meio da Ponte Pênsil.

É importante lembrar que, na década de 1950, com a construção e inauguração do Restaurante Lagosta em Praia Grande e por meio do requinte e sofisticação desse estabelecimento para os padrões da época, um outro público, de classe social mais alta, passou a freqüentar suas praias. No entanto, nessa mesma década, com a construção da Rodovia Padre Manoel da Nóbrega, facilitou-se ainda mais o acesso à Praia Grande, vindo também um grande contingente de operários da construção civil. Assim, esses operários que trabalhavam nas obras dessa rodovia e em várias outras, como, por exemplo, a construção do Conjunto Habitacional Cidade Ocian, também se encantaram com as belezas naturais da região e das praias desse distrito de São Vicente. Portanto, esse contato diário com a região praiagrandense, deve ter facilitado a fixação de residência de muitos desses trabalhadores nesse balneário.

Dentro desse contexto, cabe-se ressaltar que a inauguração do Conjunto Habitacional Cidade Ocian foi também um outro marco importante na história da urbanização da Estância Balneária de Praia Grande, não só pela introdução de novos personagens do ramo da construção civil, como pela singularidade do seu projeto para os padrões da época e inovações que o mesmo trouxe para o cenário da construção civil praiagrandense e nacional. A construção do Ocian trouxe uma nova concepção de conjunto habitacional com toda uma infra-estrutura que muitas cidades do país não tinham. 
No último capítulo, procuramos demonstrar algumas especificidades da urbanização de Praia Grande, em que após nossos estudos e análises, constatamos pelos Censos do IBGE, que a população rural reduziu-se a tal ponto que já não é mais quantificável pelos órgãos de pesquisa. Isso se deu entre as décadas de 1960 e 1970 e foi seguida por um aumento drástico da população urbana a partir de 1960 em relação ao censo de 1950.

De acordo com o IPHAN, após a entrega da primeira pista da Via Anchieta, no final da década de 1940, e com a consolidação da Região do ABC e de Cubatão como Pólo Industrial, a partir da metade da década de 1950, a Baixada Santista passou a receber um grande contingente populacional.

No entanto, a partir da primeira metade do século passado, a região do Grande ABC ao deixar de ser uma região campestre, após a década de 1930, passa a agregar várias indústrias, principalmente a indústria automobilística. Assim, com a melhoria das condições de vida a partir das décadas seguintes, 0 lazer passou a ter papel importante na vida dos trabalhadores da capital paulista, $A B C$ e adjacências e, com isso, o sonho de se obter uma segunda residência em regiões litorâneas passa a ser algo possível de ser conseguido.

Junto ao progresso promovido pelas melhorias de acessibilidade a partir da construção da Ponte Pênsil, também, vieram, sob a ponte, os emissários de esgotos das cidades vizinhas de Santos e São Vicente que eram despejados em Praia Grande in natura, causando grandes impactos ambientais. Nesse contexto, também incluímos os mais diversos tipos de agressões ao meio ambiente causadas pelos turistas de massa nas décadas seguintes.

Vale lembrar que na década de 1970, os turistas ocasionais lotavam as praias com seus ônibus. Assim, com o turismo massivo e das massas que para lá se dirigiam, a atual Estância Balneária de Praia Grande transformou-se em um lugar que foi cognominado de "praia de farofeiros", famosa por atrair classes baixas e por possuir praias sujas e poluídas, fama que perdurou por um bom tempo.

Foi também a partir dessa década, que nossos levantamentos apontaram um grande incremento da população, o qual é provável que tenha se dado devido à criação do Sistema Financeiro da Habitação e a crescente inserção da mulher 
no mercado de trabalho que, nessa ordem, facilitaram a aquisição de casa própria devido aos financiamentos, que ora se faziam disponíveis e ao aumento da renda familiar que dinamizaram a construção civil e a exploração imobiliária em todo o país e, também, nesse balneário.

Cabe-se ressaltar que, outro fato importante que ocorreu na década de 1970, foi a entrega da primeira pista da Rodovia dos Imigrantes, encurtando as distâncias entre as regiões do litoral e o Planalto Paulista. Desse modo, esta rodovia estreitou, ainda mais, os laços de Praia Grande e outras unidades da RMBS, com os importantes pólos emissores de lazer e de turismo da Metrópole de São Paulo e adjacências. Além disso, eliminou-se a necessidade de passar por Santos e São Vicente para alcançar Praia Grande, o que, de certa forma, incrementou o fluxo de turistas de segunda residência nesta região.

Já na década de 1980, a acessibilidade à cidade de Praia Grande é ainda mais facilitada pela entregas das duas pontes do Mar Pequeno, fato que, segundo Barreiros (2002, p.11), acelerou o crescimento da região e intensificou o elo de ligação com as regiões metropolitanas.

Alguns dos importantes fatos que marcaram o planejamento urbano e turístico do balneário de Praia Grande, na década de 1990, foram: a proibição da entrada dos ônibus trazendo os turistas de um dia para a cidade, a criação de sua Lei Orgânica, seu primeiro Plano Diretor e a criação da Lei de Ordenamento do Uso, da Ocupação e do Parcelamento do Solo. Esses fatos trouxeram muitos benefícios e proporcionaram um crescimento e um desenvolvimento mais ordenado da cidade.

Contudo, a partir da década de 1990, verificamos que Praia Grande passa por um intenso e contínuo processo de reurbanização de sua orla e adjacências que visou consolidar essa estância como importante núcleo turístico. Nesse sentido, essas mudanças na paisagem trouxeram mais investimentos para a cidade, aquecendo o mercado imobiliário e da construção civil e, com isso, a demanda por imóveis de segunda residência em Praia Grande aumentou consideravelmente.

Comparando os dados obtidos dos censos do IBGE de 1991 e 2000, constatamos que o turismo da região tem sua maior participação em moradias de 
segunda residência a partir dessa época. As suas mais de 93.275 segundas residências, conforme estes levantamentos, foram e são responsáveis pelos alojamentos dos grandes fluxos de turistas que para lá se dirigem aos finais de semana, férias e nas altas temporadas. Por conta disso, é de interesse dessa estância balneária continuar investindo pesado em infra-estrutura, pois trata-se de uma atividade que é consumidora do espaço geográfico, exigindo, portanto, facilidades de acesso e melhorias na infra-estrutura básica, tais como: saneamento, saúde pública, segurança e outros de suma importância, que devem ser oferecidos pela cidade aos turistas e moradores.

Em nossos levantamentos, foram apontados vários dados importantes em relação às características, comportamentos e queixas dos turistas e moradores desse balneário e esperamos que ações possam ser tomadas no sentido de sanar tais deficiências.

Nos dias atuais, ou seja, a partir do terceiro milênio, a atual Estância Balneária de Praia Grande, passa a incorporar a sua paisagem prédios com mais de 20 andares e com toda a infra-estrutura de verdadeiros clubes, com as mais variadas opções de comodidade e lazer em suas dependências. Dentro desse contexto, com a chegada das grandes e famosas construtoras de nosso país, nesse balneário, inicia-se uma nova fase de verticalização e exploração imobiliária na cidade.

Sendo assim, no bojo das transformações que ocorreram em decorrência da exploração imobiliária do turismo de segunda residência e verticalização na cidade de Praia Grande, temos uma conseqüente valorização do seu solo urbano nas regiões próximas à sua orla marítima e também a expulsão das populações mais carentes dessa região para as áreas localizadas do lado direito da SP-55 (no sentido Mongaguá).

Ressaltamos que, além dos resultados obtidos por meio de nossos levantamentos de campo, junto aos órgãos públicos, moradores e turistas, também percebemos de forma empírica, devido ao fato de nossa família manter residências de uso ocasional em Praia Grande, desde o princípio da década de 1960, o quanto se tem investido em obras de reurbanização nesse balneário, principalmente a partir da década de 1990 para cá. 
Desse modo, essas mudanças, aliadas à bela paisagem cercada por riquezas ambientais e ecológicas, sua privilegiada localização servida por pontes e rodovias modernas que facilitaram e diminuíram consideravelmente o tempo de deslocamento com os pólos emissores de turismo, dão, a esse balneário da RMBS, uma grande vantagem competitiva em relação às demais regiões vizinhas. O espetacular crescimento de Praia Grande fornece um primeiro indicador da magnitude das mudanças experimentadas pela região praiagrandense do início do século passado para cá.

Neste sentido, evidenciaram-se as mudanças na paisagem da orla marítima local, tornando-se, assim, em um novo atrativo para captação de investimentos e turistas para essa cidade-média paulista.

Vale mencionar que notamos, ainda, tanto empiricamente, quanto por meio de nossas análises, o quanto um dos agentes de transformação, a administração pública, pode transformar o espaço, a paisagem e dar uma nova embalagem a um lugar turístico e devolver o glamour dos tempos de outrora. Isso é o que vem acontecendo com Praia Grande a partir da década de 1990 para cá, com um contínuo processo de reurbanização de sua orla marítima e região e com várias melhorias em sua infra-estrutura local.

No entanto, a história de Praia Grande é pontuada por glórias e problemas, desde os primórdios do século XIX, mas, a partir da década de 1990, a administração pública da cidade, sob a administração do Prefeito Alberto Pereira Mourão, adotou uma estratégia que envolveu duas frentes: investimentos pesados em infra-estrutura e mudança radical da paisagem da cidade, que, ao mesmo tempo que atrai um novo perfil de turistas, também contribui ainda mais para a exclusão dos mais carentes.

Verificamos, por meio de nossos levantamentos, os vários efeitos, tanto bons quanto ruins, que regiões propulsoras de grandes impactos ambientais, como as regiões metropolitanas, podem trazer para uma estância balneária. Entre as boas conseqüências temos: a melhoria dos meios de comunicação com esses grandes centros, a geração de empregos, a captação de investimentos, melhorias de infra-estrutura local, entre tantas outras. Além das boas, temos também as más conseqüências, tais como: o desabastecimento d'água, trânsito nas entradas e 
saídas da cidade durante as altas temporadas e finais de semana (trazendo problemas de mobilidade para os moradores fixos e ocasionais da cidade), problemas com a segurança, sujeira das praias e adjacências, comprometimento da balneabilidade de suas praias, atendimento de saúde e tantos outros.

Contudo, se projetos como o "Projeto Onda Limpa", que visa a despoluição das praias até 2011, e tantos outros, forem postos em prática, e ainda, se tais investimentos na infra-estrutura local da cidade forem proporcionais ao seu crescimento urbano, os impactos e os danos ao seu meio-ambiente serão minimizados e sua qualidade como estância balneária não será tão afetada pelo excesso de população proveniente das mais variadas regiões metropolitanas durante as altas temporadas, finais de semana e feriados.

Hoje em dia, a Praia Grande, após reverter a imagem ruim que teve por quase três décadas, tem recuperado nos últimos vinte anos, seu prestígio e balneabilidade de suas praias, após fortes investimentos por parte da administração pública da cidade.

Não só constatamos, tanto de forma empírica quanto cientifica, os efeitos negativos que um turismo desenfreado pode causar a um lugar turístico, além de um sem-número de problemas sérios para a comunidade, como, por exemplo, a poluição e até a desvalorização do lugar turístico, tanto na parte que se refere ao espaço quanto no imaginário das pessoas que os visitam, mas, também, verificamos que, quando há a boa vontade e empenho dos agentes públicos e privados, ou até mesmo da comunidade local, ou, ainda, com a união destes, situações que parecem muitas vezes irreversíveis, podem ser modificadas.

Assim, constatamos por meio de nossos levantamentos que hoje essa cidade-média paulista busca novas opções para incrementar o seu turismo local, como por exemplo, a criação e futura inauguração de um Centro Cultural, onde haverá um auditório e salas para exposições de artes e também um Museu de História da Cidade e tantos outros projetos e empreendimentos turísticos. Dentro desse contexto, Praia Grande busca, ainda, uma maior participação no Turismo de Negócios e Eventos, visando com isso incrementar ainda mais suas potencialidades turísticas e econômicas e trazer mais recursos e investimentos para a cidade. Lembramos que esse Turismo de Negócios e Eventos apresenta-se 
como uma atividade muito rentável no setor turístico e oferece grandes possibilidades de crescimento, tendo em vista a globalização econômica pela qual o mundo tem passado, em especial com acordos firmados com o Mercosul ${ }^{74}$, Aladi $^{75}$ e tantos outros.

Portanto, a bela paisagem cercada por riquezas ambientais ecológicas da Estância Balneária de Praia Grande, hoje considerada "A Princesinha da Mata Atlântica", também propicia o desenvolvimento de outras modalidades de turismo além do turismo de segunda residência, tais como o educacional e ecológico que são fortemente amparados por uma coordenadoria da Secretaria da Educação da Estância Balneária de Praia Grande.

Sendo assim, no âmbito geral, a pesquisa evidenciou uma significativa transformação desse balneário, onde desenvolveu-se, em Praia Grande, desde os primórdios de sua ocupação, um intenso e complexo processo de urbanização, que se traduz, por um lado, pela periferização dos seus mais carentes e, por outro, pela supervalorização do espaço nas regiões mais próximas à sua orla marítima.

Uma das conseqüências ruins desse processo de urbanização, exploração imobiliária e conseqüente crescimento desta estância, foi a exclusão de parte de seus cidadãos mais pobres. Nos dias atuais, Praia Grande tem do lado direito da Rodovia Padre Manuel da Nóbrega (ou SP-55 - no sentido Mongaguá), a população mais carente de sua cidade, que em visitas a algumas dessas regiões, constatamos a necessidade de melhorias de suas infra-estruturas locais de modo a levar a essa população os benefícios não só do crescimento, mas também do desenvolvimento urbano.

No entanto, foi por meio da exploração do turismo de segunda residência que, ao mesmo passo que é introdutor de inovações para a cidade, gerando empregos locais, transferindo recursos e capitais para a sua região, devido ao fato desta cidade-média ter hoje em dia o seu espaço espetacularizado, também trouxe em seu bojo a expulsão dos mais carentes, trazendo ainda conseqüências boas e ruins para o balneário. E, ainda, requer, no entanto, especial atenção para

\footnotetext{
${ }_{74}^{74}$ Mercado Comum do Cone Sul.

${ }^{75}$ Associação Latina Americana de Integração.
} 
os impactos ambientais de modo a não deixar que os mesmos degradem o seu meio ambiente.

Diante de tudo o que foi pesquisado e exposto, constatamos que se essa cidade-média conseguiu recuperar seu prestígio, que por décadas foi comprometido, foi em razão de um processo de planejamento envolvendo os vários elementos que são indispensáveis ao sucesso dessa prática social do turismo e foram eles: os agentes públicos, privados e a comunidade local. Porém, ainda há muito o que ser feito em termos de infra-estrutura, mobilidade, balneabilidade das praias, entre tantos outros pontos a serem melhorados.

Também, verificamos por meio de nossos estudos e pesquisas, que o desenvolvimento do turismo de segunda residência em Praia Grande é um forte propulsor do setor imobiliário e da indústria da construção civil, sendo, portanto, necessário para o crescimento e desenvolvimento da região. Também contatamos o quanto o espaço dessa estância foi transformado ao longo dos anos por meio da exploração imobiliária promovida pelo turismo de segunda residência e apoiado fortemente pelas viagens de curta duração e melhoria dos meios de comunicação entre Praia Grande e os pólos emissores do turismo das mais variadas regiões metropolitanas de nosso estado.

Dentro desse contexto, nota-se a importância da metrópole de São Paulo e demais regiões para o crescimento e desenvolvimento de Praia Grande, no entanto, foram apontadas muitas queixas de turistas e moradores que comprometem o sucesso alcançado até então. Portanto, sugere-se que tanto os agentes públicos quanto privados, possam agir rapidamente na solução dessas deficiências de modo a não comprometer sua qualidade e atratividade como estância balneária, promovendo suas potencialidades e não só o crescimento, mas também o desenvolvimento de sua cidade e região. Cabe-se ressaltar que o atendimento das exigências, tanto de turistas quanto de moradores, é crucial para a manutenção do sucesso que Praia Grande vem alcançando em mudar a imagem ruim que teve por tanto tempo.

Por fim, concluímos que a proximidade de Praia Grande com importantes pólos emissores de turismo é um grande diferencial na atração de turistas para essa cidade e que os processos de urbanização, embelezamento e 
melhoramentos urbanos pelo qual passou Praia Grande, nas sucessivas gestões municipais, objetivaram consolidar essa estância como importante pólo receptor do turismo de segunda residência, porém, para continuar incentivando a iniciativa privada a trazer investimentos para a cidade, medidas urgentes devem ser tomadas, principalmente, no que se refere à sujeira das praias, abastecimento de água e melhoria da mobilidade nas entradas e saídas do balneário nos dias de maior concentração populacional em sua região.

Finalizando, essas mudanças e melhorias irão requerer um ambicioso plano de intervenção viária e urbanística. Dessa forma, diante de tantos desafios na área de planejamento urbano que a Estância Balneária de Praia Grande tem enfrentado desde sua emancipação para cá, essa cidade tem mostrado que uma boa gestão pública, aliada aos investimentos da iniciativa privada, pode reverter as conseqüências ruins causadas pelo crescente aumento de sua população atual e que se intensifica ainda mais nas altas temporadas pelo fato de estar próxima a grandes e complexos centros urbanos e regiões metropolitanas. 


\section{REFERÊNCIAS:}

AFONSO, Cíntia Maria. A paisagem da baixada santista: urbanização, transformação e conservação. São Paulo: Edusp, 2006.

ARROYO, Mônica. São Paulo e os fluxos internacionais de mercadorias: a espessura de uma região metropolitana. In: CARLOS, Ana Fani Alessandri; OLIVEIRA, Ariovaldo Umbelino de (Org.). Geografias de São Paulo: A metrópole do século XXI. São Paulo: Contexto, 2004.

ARQUIVO HISTÓRICO DE SÃO VICENTE.

A TRIBUNA, Santos, s.d., s.p.

. Santos de 24 abr. 1983. Especial Cidades. Capa.

. Santos, 19 jan. 1989. Caderno Baixada \& Litoral, s.p.

. Santos, 04 abr. 2004. Caderno Cidades, B-3 p.

. Santos, 19 jan. 2005. Especial Municípios. 2 p.

AZEVEDO, Aroldo de. Vilas e cidades do Brasil Colonial (Ensaio de geografia urbana retrospectiva). São Paulo: Terra livre, n.10, p 28, jan.-jul. 1992.

BARREIROS, Mário Antonio Ferreira. Plano metropolitano de desenvolvimento integrado - Cadernos metropolitanos: sistema de circulação e transporte - caderno no 5. São Paulo: Agem, 2002.

BOYER, Marc. História do turismo de massa. São Paulo: Edusc, 2003.

CAMARGO, Nadia Aparecida Lopes. A Geografia das lutas metalúrgicas no ABC paulista na virada dos anos 70 do século XX. Dissertação (Mestrado em Geografia Humana). Faculdade de Filosofia, Letras, Ciências Humanas. Universidade de São Paulo, SP, 2003.

BRASIL, Distrito Federal. Lei Federal no 5741, de 01 de dezembro de 1971: instituiu o Sistema Financeiro de Habitação. Senado Federal, 1971.

BRASIL, Distrito Federal. Lei Federal n¹0.257, de 10 de julho de 2001: instituiu o Estatuto da Cidade. Senado Federal, 2001.

BRASIL, Praia Grande. Lei Complementar nํ 473, de 27 de dezembro de 2006: aprova o plano diretor da Estância Balneária de Praia Grande para o período de 
2007-2016. Prefeitura da Estância Balneária de Praia Grande, 2006. Anexo III, item 7-8.

BRASIL, Praia Grande. Lei Municipal no 793, de 08 de janeiro de 1993: aprova bloqueios a entrada de ônibus com turistas de um dia. Prefeitura Municipal da Estância Balneária de Praia Grande, 1993.

BRASIL, Santos. Recurso Extraordinário n²4.915, d e 14 de junho de 1954. Maria Celeste Constant versus Maria José do Espírito Santo. Relator Lafayette de Andrada. Prefeitura Municipal de Santos, 1954.

BRASIL, São Paulo. Lei Complementar no 853 de 23/12/1998: cria a AGEM Agência Metropolitana da Baixada Santista. Governo do Estado de São Paulo, 1998.

BRASIL, São Paulo. Lei Estadual n`8092 de 28/02/19 64: cria o distrito e município da Estância Balneária de Praia Grande com sede no Boqueirão. São Paulo. Governo do Estado de São Paulo, 1964.

BRASIL, São Vicente. Edital no 344, de 28 de abril de 1944: disposição de vilas em Praia Grande. Prefeitura Municipal de São Vicente, 1944.

CASTELLS, Manuel. A sociedade em rede. $2^{\underline{a}}$ ed. - Rio de Janeiro: Paz e Terra, 1999.

CARLOS, Ana Fani Alessandri, OLIVEIRA; Ariovaldo Umbelino de (Org.). Geografias de São Paulo: A metrópole do século XXI. São Paulo: Contexto, 2004. CASELLA, Luana L. de Camargo. Turismo sustentável: realidade possível?

O caso do Município de Bertioga, SP. Dissertação (Doutorado em Geografia Física). Faculdade de Filosofia, Letras, Ciências Humanas. Universidade de São Paulo, SP, 2004.

CASTRO, Ina Elias de. Questões atuais da reorganização do território. In: COSTA, Paulo César da; CORREA, Roberto Lobato (Org.). Rio de Janeiro: Bertand Brasil, 1996.

CRUZ, Rita de Cássia Ariza da. Turismo e impacto em ambientes costeiros: Projeto Parque das Dunas-Via Costeira, Natal (RN). Dissertação (Mestrado em Geografia Humana). Faculdade de Filosofia, Letras, Ciências Humanas. Universidade de São Paulo, SP, 1995. 
.Políticas de Turismo e (re) ordenamento de territórios no litoral do Nordeste do Brasil. Tese (Doutorado em Geografia Humana). Faculdade de Filosofia, Letras, Ciências Humanas. Universidade de São Paulo, SP, 1999. .Introdução à geografia do turismo. 2ª ed. - São Paulo: Roca, 1992. .Turismo, espaço, paisagem e cultura. 2ª ed. - São Paulo: Hucitec, 1999.

DAVIS, Kingsley e outros. Cidades - A urbanização da Humanidade. Rio de Janeiro: Zahar, 1977.

DCI, São Paulo, 21, 22, 23 out. 2006. Caderno C. C-1 p.

DEUS, João Batista de. O sudeste Goiano: As transformações territoriais da desconcentração industrial brasileira. Tese (Doutorado em Geografia Humana). Faculdade de Filosofia, Letras, Ciências Humanas. Universidade de São Paulo, SP, 2002.

DERSA - Desenvolvimento Rodoviário S.A.

DCl, São Paulo, 21, 22, 23 out. 2006. Caderno C. C-1 p.

DOLFFUS, Olivier. O espaço geográfico. Rio de Janeiro: Bertrand Brasil, 1991.

EMPLASA. - Empresa Paulista de Planejamento Metropolitano S.A.

FERRARA, Lucrecia D' Alessio. São Paulo, Brasil: da imagem local a identidade global. In: SOUZA, Maria Adélia Aparecida de et alii. Metrópole e Globalização: Conhecendo a cidade de São Paulo. São Paulo: Cedesp, 1999.

GERODETTI, João Emilio, CORNEJO, Carlos. Lembranças de São Paulo: o litoral paulista nos cartões-postais e álbuns de lembranças. São Paulo: Solaris Edições Culturais, 2001.

GOULART, Nestor. Notas sobre a organização das Regiões Metropolitanas. cadernos de pesquisa $L A P$, Série urbanização e urbanismo. São Paulo: Laboratório de Estudos sobre Urbanização, Arquitetura e Preservação, Depto de Historia da Arquitetura e Estética do Projeto - FAU-USP, mar-abr. 1996.

GUIA DO PROFISSIONAL DE EVENTOS PARA SANTOS E REGIÃO. São Vicente: Vice Rei, 2003.

GUIMARAES, Mario. São Paulo, quatro séculos de luta. Rio de Janeiro: Gráfica Vitória, 1954. 
GÓMEZ, Alberto L. De la geografia del turismo al estúdio de las atividades de ócio - algunos problemas conceptuales. Estúdios turísticos, Espanha, n. 98, p. 43-58, 1988.

HOLANDA, Sérgio Buarque de. Raízes do Brasil. Rio de Janeiro: Jose Olympio, 1936.

IBGE - Manual do Recenseador. Censo de 2000.

IBGE- Dados oficiais dos Censos de 1920, 1940, 1950, 1960, 1970, 1980, 1991, 1996 e 2000.

IBGE. Enciclopédia dos Municípios Brasileiros. Rio de Janeiro: IBGE, 1958. v. XXX, p. 274.

IGC - Instituto Geográfico e Cartográfico.

IGC - Manual de Municípios e Distritos do Estado de São Paulo, São Paulo: IGC, 1995.

IPHAN - Instituto do Patrimônio Histórico e Artístico Nacional.

IGNARRA, Luiz Renato. O turismo de segunda residência no município de São Sebastião e seus impactos econômicos. Dissertação (Mestrado em Turismo). Escola de Comunicação e Artes. Universidade de São Paulo, SP, 1999.

JONHSTON, R. J. City and society. Inglaterra: Penguin, 1980.

LEE, Magda Starke. Balneário Camboriú: Desenvolvimento de uma cidade litorânea. Dissertação (Mestrado em Geografia Humana). Faculdade de Filosofia, Letras, Ciências Humanas. Universidade de São Paulo, SP, 1998.

LOPES, Antonio Augusto de Sá. A odisséia de um motorista. São Paulo: Obelisco, 1961.

LOPES, Maria Immacolata Vassalo. Pesquisa em comunicação. 8 a ed. - São Paulo: Loyola, 2005.

MACEDO, S.S. \& PELLEGRINO, P.R.M. Do éden à cidade: transformação da paisagem litorânea brasileira. In: YÁZIGI, Eduardo, CARLOS, Ana Fani Alessandri, CRUZ, Rita de Cássia Ariza (Org.). Turismo, espaço e cultura. São Paulo: Hucitec, 1996.

MACHADO JUNIOR, Armando Marcondes. Divisão territorial do Estado de São Paulo. São Paulo: A.M. Machado Jr, 2005. 
MAGALHÃES, Erasmo D' Almeida. Baixada santista, aspectos geográficos: Santos e as cidades balneárias. São Paulo: Edusp, 1965. MARX, Murillo. Nosso chão: do sagrado ao profano. São Paulo: Edusp, 1988. Cidade no Brasil terra de quem? São Paulo: Nobel, 1991.

MIDAGLIA, Carmen Lúcia. Turismo e meio ambiente no litoral paulista: dinâmica da balneabilidade nas praias. Dissertação (Mestrado em Geografia Humana). Faculdade de Filosofia, Letras, Ciências Humanas. Universidade de São Paulo, SP, 1994.

NAVARRO, Eduardo de Almeida. Dicionário de Tupi Antigo - A língua indígena Clássica do Brasil. São Paulo: Global (no prelo).

NICOLAS, Daniel $\mathrm{H}$. Elementos para um analisis sociogeográfico del turismo. In: RODRIGUES, Adyr A. B. (Org.). Turismo e geografia - reflexões teóricas e enfoques regionais. São Paulo: Hucitec, 1996.

O CORREIO DA MANHÃ, São Vicente, 27 fev. 1944. Capa.

O DIÁRIO REGIONAL, São Paulo, 14 dez. 2006, Capa.

O DIÁRIO DE SANTOS, Santos, dez. 1902, s.p.

O DIÁRIO DE SÃO PAULO, São Paulo, 20 jan. 2008, Caderno A. 5 p.

OLIVEIRA, Ariovaldo Umbelino de, CARLOS, Ana Fani Alessandri (Org.). Geografias de São Paulo: A metrópole do século XXI. São Paulo: Contexto, 2004. OLIVEIRA, Carlos Roberto de. Boiçucanga: de bairro rural a bairro urbano. Dissertação (Mestrado em Geografia Humana). Faculdade de Filosofia, Letras, Ciências Humanas. Universidade de São Paulo, SP, 1998.

OUTEIRO DE SANTA CATARINA (Santos).

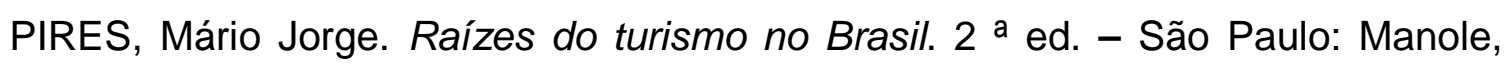
2002.

PRAIA Grande. A Tribuna, Santos, 19 jan. 2008. Especial. 2 p.

PRAIA Grande. A Tribuna, Santos, 19 jan. 2008. Especial. 8 p.

PREFEITURA MUNICIPAL DA ESTÂNCIA BALNEÁRIA DE PRAIA GRANDE Secretarias da Cultura, Meio-Ambiente, Obras Públicas, Planejamento Urbano e Turismo.

RAFFESTIN, Claude. Por uma geografia do poder. São Paulo: Ática, 1993. 
RODRIGUES, Adyr A. B. Turismo e geografia - reflexões teóricas e enfoques regionais. São Paulo: Hucitec, 1996.

- Turismo e espaço - rumo a um conhecimento transdisciplinar. São

Paulo: Hucitec, 1997.

RODRIGUES, André Figueiredo. Como elaborar e apresentar monografias. $2^{\mathrm{a}}$ ed.

- São Paulo: Humanitas, 2006.

- Como elaborar citações e notas de rodapé. 4ํㅡ ed. - São Paulo:

Humanitas, 2007.

Como elaborar referências bibliográficas. 6a ed. - São Paulo:

Humanitas, 2007.

RODRIGUES, Arlete Moysés. A produção e o consumo do espaço para o turismo e a problemática ambiental. In: YÁZIGI, Eduardo, CARLOS, Ana Fani A. (Org.). Turismo, espaço, paisagem e cultura. ํํe. São Paulo: Hucitec, 1999.

SANCHEZ, Joan-Eugeni. Espacio, economia y sociedad. Espanha: Siglo Veintiuno, 1991.

SANTOS, Cátia Pereira dos. De arraial de Porto Alegre a cidade de Itaperuna: Especificidade de uma urbanização com traços do rural. Dissertação (Mestrado em Geografia Humana). Faculdade de Filosofia, Letras, Ciências Humanas. Universidade de São Paulo, SP, 2006.

SANTOS E REGIÃO CONVENTION \& VISITORS BUREAU.

SANTOS, Milton. Por uma geografia nova. São Paulo: Hucitec, 1980.

. A natureza do espaço - técnica e tempo, razão e emoção. São Paulo:

Hucitec, 1996.

O Brasil: Território e sociedade no inicio do século XXI. $3^{\text {a }}$ ed - Rio de Janeiro: Record, 2001.

. Pensando o espaço do homem. São Paulo: Edusp, 2004.

. A urbanização brasileira. 5ª ed. - São Paulo: Edusp, 2005.

SEABRA, Odette Carvalho de Lima. A muralha que cerca o mar. Dissertação (Mestrado em Geografia Humana). Faculdade de Filosofia, Letras, Ciências Humanas. Universidade de São Paulo, SP, 1979.

SECOMANDI, Elcio Rogério. Circuito turístico dos fortes: Região Metropolitana da Baixada Santista. Santos: Editora Universitária Leopoldianum, 2005. 
SENRA, Jorge Bierrenbach. O Monumento, São Vicente, Ano III no 23, jul. 1983. SERRA, Geraldo. O espaço natural e a forma urbana. São Paulo: Nobel, 1987. SIQUEIRA, Fátima Valéria; SILVA, Mônica Solange Rodrigues e; CALIS, Magna Flora. Paisagens da memória: história de Praia Grande. Praia Grande, SP: Prefeitura da Estância Balneária de Praia Grande, 2002.

SOUZA, Maria Tereza Sadek R. de. Concentração industrial e estrutura partidária: o progresso eleitoral no ABC 1966-1982. Dissertação (Mestrado em Ciência Política). Faculdade de Filosofia, Letras, Ciências Humanas. Universidade de São Paulo, SP, 1984.

SOUZA, Maria Adélia Aparecida de. A identidade na Metrópole: a verticalização em São Paulo. São Paulo: Hucitec, 1989.

- Metrópole e Globalização: conhecendo a cidade de São Paulo In:

SOUZA, Maria Adélia Aparecida de et alii. São Paulo: Cedesp, 1999.

SUZUKI, Júlio César. De povoado a cidade: A transição do rural ao urbano em Rondonópolis. Dissertação (Mestrado em Geografia Humana). Faculdade de Filosofia, Letras, Ciências Humanas. Universidade de São Paulo, SP, 1996.

THOMAS, Georg. Política indigenista dos portugueses no Brasil: 1500-1640. (tradução do Pe. Jesus Hortal) São Paulo: Loyola, 1981.

TOSCHI, Circe Sanchez. Praia Grande antes da emancipação. Santos: Espaço do Autor, 2003.

TULIK, Olga. Residências secundárias: presença, dimensão e expressividade do fenômeno no Estado de São Paulo. Tese (Livre-Docência). Escola de Comunicação e Artes. Universidade de São Paulo, SP, 1995.

VOLVELLE, Michel. Ideologias e mentalidades. Tradução de Maria Julia Cottvasser. São Paulo: Brasiliense, 1987.

\section{FONTES DE IMAGENS DAS PÁGINAS DE ABERTURA DA CAPA, INTRODUÇÃO, CAPÍTULOS E CONCLUSÃO}

Capa - Disponível em: http://www.novomilenio.inf.br/pg/pgf001.htm, acesso em 18/06/2006, por Imário Vieira. 
Página 16 - Disponível em: http://www.novomilenio.inf.br/pg/pgf001.htm, acesso em 18/06/2006, por Imário Vieira.

Página 40 - Disponível em: http://www.novomilenio.inf.br/cubatao/ch003.htm, acesso em 11/01/2007, por Imário Vieira.

Página 82 - Disponível em: http://www.vistamar.com.br/CIDADE.HTM, acesso em 05/10/2005, por Imário Vieira.

Página 137 - Disponível em: http://www.praiagrande.sp.gov.br/Praiagrande/ index-.asp?cd pagina=77\&principal=290, acesso em 22/02/2006, por Imário Vieira.

Página 209 - Fonte: Gustavo Raul Silva Martinez - Autor: Gustavo Raul Silva Martinez. 


\section{ANEXOS}




\section{Anexo A - Resultados da Pesquisa de Campo}

\section{Resultados das Pesquisas de Campo}

A pesquisa de campo de fonte primária foi realizada por meio de dois questionários distintos - Modelo A (para moradores permanentes) e Modelo B (para moradores de segunda residência e turistas de um modo geral). Ao todo foram realizadas 2.450 entrevistas com os dois grupos $A$ e $B$, subdivididas da seguinte forma:

1) Para o Modelo A (para moradores fixos e/ou permanentes) - foram realizadas 800 entrevistas entre os meses de maio e dezembro de 2007, especificamente nos dias 19/20/26/27 de maio, 30/Jun, 01/Jul, 04 e 05/Ago, 29 e 30/Set, 27 e 28/Out, 03 e 04/Nov, 01 e 02/Dez do ano de 2007. Para a realização da pesquisa do Modelo $A$, subdividimos os entrevistados em duas partes ou etapas diferentes e são elas:

1' Etapa - correspondeu a 400 questionários para a população do lado esquerdo e mais próximo da Rodovia SP 55 - no sentido Mongaguá (Zona 2);

2ª Etapa - correspondeu a outros 400 questionários para a população do lado direito da Rodovia SP 55 - no sentido Mongaguá (Zona 3);

Essas duas partes da pesquisa foram realizados nas regiões que vão da região próxima ao Terminal Tude Bastos até a região próxima da divisa com Mongaguá.

2) Para o Modelo B (para moradores de segunda residência e/ou turistas de um modo geral) - foram realizadas 1650 entrevistas, entre os meses de junho de 2007 e janeiro de 2008, especificamente nos dias 07/08/09/10 de junho, dias 26/27/28/29 de julho, dias 18/19/20 de agosto, dias 07/08/09 de setembro, dias 12/13/14 de outubro, dias 02/24/25 de novembro, dias 
01/02/21/22/23 de dezembro de 2007 e dias 04/05/06/17/18/19/20 de janeiro de 2008. Este questionário foi destinado para os turistas de um modo geral e aos de segunda residência, em especial, aos que possuem residência ocasional na região mais próxima a orla (Zona 1). Dessa forma, como 0 balneário possui 12 praias, foram realizadas em torno de 138 entrevistas em cada praia da cidade, totalizando as 1650 entrevistas.

Notou-se uma grande receptividade e colaboração com a precisão das respostas, ou seja, em responder fielmente aquilo que thes era perguntado em relação à pesquisa realizada. Muitas vezes após o término do questionário, uma grande parte dos entrevistados queria ficar conversando conosco para dar opiniões e saber se a prefeitura da cidade tomaria conhecimento de suas respostas, de modo que, medidas cabíveis fossem tomadas para resolver alguns dos problemas e deficiências apontadas na pesquisa. Os resultado coletados foram os seguintes:

\section{1 - Para o Modelo A (moradores permanentes)}

\section{Questionário Modelo A (aos moradores permanentes/fixos)}

\section{1- Entrevistados: (334) Sexo Masculino (466) Sexo Feminino \\ 2- Qual a sua idade?}

(090) Até 20 anos(091) de 20 a 30 anos (238) de 30 a 40 anos (200) de 50 a 60 anos

(181) mais de 60 anos

\section{3- Qual seu nível de escolaridade?}

(077) de $1^{\underline{a}}$ a $4^{\underline{a}}$ serie $(129)$ de $5^{\underline{a}}$ a $8^{\underline{a}}$ serie $(147) 2^{\circ}$ grau incompleto

(164) $2^{\circ}$ grau completo (165) superior incompleto (098) superior completo

(019) pos graduação Lato Sensu (001) mestrado (000) doutorado

4- Qual a renda familiar?

(476) de 1 a 5 salários mínimos (272) de 5 a 10 salários mínimos

(052) mais de 10 salários mínimos

5- Há quantos anos vive em Praia Grande?

(332) menos de 10 anos (330) de 10 a 20 anos (091) de 20 a 30 anos

(023) de 30 a 40 anos (022) de 40 a 50 anos (002) mais de 50 anos

6- Qual o local de procedência antes de viver em Praia Grande?

(073) Santos (166) São Vicente (081) Cubatão (030) Outros da RMBS (122) São Paulo (052) ABC paulista (060) Outras regiões SP (109) Nasceu em P.Gde (107) Outro estado

7- Em que tipo de imóvel vive?

(556) próprio (244) alugado

7A- Qual 0 tipo $/$ espécie do imóvel? 
(475) casa de alvenaria (012) Casa de madeira (313) apartamento (000) outros

7B-. Se imóvel próprio, há quanto tempo o possui?

(032) até 1 ano (074) de 1 a 3 anos (106) de 3 a 6 anos (076) de 6 a 9 anos

(129) de 9 a 11 anos (076) de 11 a 20 anos (031) de 20 a 40 anos (011) mais de 40 anos

8- Já morou em outra (das 3 zonas existentes) em Praia Grande?

(000) $\operatorname{sim}$ (800) não

9- Qual sua (área) profissão?

(206) administrativa (189)vendas (276)comercio/serviços

(040) construição civil (060) servidor público (029) outros

10- Teve ancestrais caiçaras e/ou pescadores em Praia Grande?

(001) sim (799) não

11- Trabalha na própria cidade?

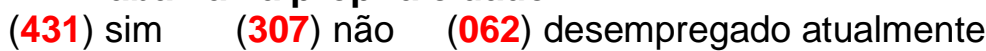

11A- Onde trabalha ou trabalhou por último?

(438) Praia Grande (051) Santos (093) São Vicente (087) Cubatão (018) Outros da RMBS

(082) São Paulo (031) ABC paulista (000) Outras regiões SP

12- $O$ que acha da infra-estrutura da cidade de Praia Grande hoje?

(226) Ótima (323) Boa (184) Regular (067) Ruim

12A- Na sua opinião, o que deve ser melhorado?

(361) Abastecimento de água (143) Limpeza das praias (071) Saúde (171) Segurança

(000) Eletricidade (046) Esgoto (008) Arruamentos (000) Outros

13- A infra-estrutura do seu bairro te satisfaz?

(568) Sim (232) Não

14- $O$ que acha das mudanças urbanísticas da cidade de Praia Grande das últimas duas décadas para cá?

(425) Ótima (286) Boa (088) Regular (001) Ruim

15-O que faz em termos de lazer?

(338) praia (041) parques (162) pedalar (046) pescar (168) Visita Shoppings

(016) visita outras cidades (027) pratica esportes náuticos (002) Outras atividades

16- Acha da segurança em Praia Grande?

(230) Ótimo (373) Bom (143) Regular (054) Ruim

17- $O$ que acha da balneabilidade das praias?

(160) Ótima (300) Boa (194) Regular (146) Ruim

18- Se você fosse dar uma nota à sujeira nas praias durante o dia, qual nota daria?

Quanto mais alto a nota, mais suja é a praia.

(020) Zero (066) de 1 a 2 (138) de 3 a 4 (239) de 5 a 6 (253) de 7 a 8 (084) de 9 a 10

18A- $O$ que acha da limpeza das praias?

(049) Ótima (227) Boa (343) Regular (181) Ruim

19- $O$ que acha da limpeza das ruas e da cidade em geral?

(565) Ótima (217) Boa (018) Regular (000) Ruim

20- $O$ que acha que é pior quando os turistas estão por aqui?

(180) Falta d'água (221) sujeiras das praias (004) sujeiras das ruas (065) filas

(061) atendimento de Saúde (072) falta de Segurança

(197) trânsito / congestionamentos (000) outros

Muito Obrigado! 


\section{2- Para o Modelo B (moradores de segunda residência e turistas de um modo geral)}

\section{Questionário Modelo B (turistas de segunda residência e turistas em geral)}

\section{1- Entrevistados: (726 ) Sexo Masculino ( 924) Sexo Feminino}

\section{2- Qual o local de procedência?}

(958) São Paulo (059) Santos e região (386) ABC Paulista (111) Campinas e região (107) outros lugares do estado de SP.Qual?

(029) outro estado. Qual?

3- Qual a sua idade?

(113) Até 20 anos(248) de 20 a 30 anos (595) de 30 a 40 anos (397) de 50 a 60 anos (297) mais de 60 anos

4- Qual a sua renda familiar?

(577) de 1 a 5 salários mínimos (982) de 5 a 10 salários mínimos

(091) mais de 10 salários mínimos

5- Qual seu nível de escolaridade?

(078) de 1 a 4 serie (169) de 5 a 8 serie (338) 2 grau completo (202) 2 grau incompleto

(385) superior incompleto (357) superior completo (113) pos graduação Lato Sensu

(008) mestrado (000) doutorado

\section{6- Em que tipo de imóvel se hospeda?}

(754) Casa/Apto próprio (521) imóvel alugado (182) Casa/Apto parentes/amigos

(043) Hotel (000) Camping (000) Albergue (004) Pousada (107) Clube de férias

(039) outros. Quais?

6A- Se imóvel próprio, há quanto tempo o possui?

(009) até 1 ano (083) 1 a 3 anos (187) de 3 a 6 anos (085) de 6 a 9 anos

(121) de 9 a 11 anos (145) de 11 anos a 20 anos (075) de 20 a 40 anos

(049) mais de 40 anos

7- Qual o tipo de transporte utilizado para vir a Praia Grande?

(1259) Carro (151) Moto (219) Ônibus (021) Veículos Alugados (000) Outros.

Quais

8- Quanto tempo (em geral) fica na cidade?

(029) Durante o dia, sem pernoitar (1317) 2 dias (final de semana) (205) de 2 a 5 dias

(054) de 5 a 7 dias (045) mais de 7 dias

9- Com que freqüência visita a cidade?

(632) Todas as semanas (838) de 15 em 15 dias (034) a cada 20 dias

(123) 1 vez por mês (021) 1 vez a cada 3 meses (002) 1 vez a cada 6 meses

(000) 1 vez por ano.

10- Há quanto tempo freqüenta a cidade?

(041) menos de 1 ano (130) de 1 a 2 anos (535) de 2 a 5 anos (417) de 5 a 8 anos

(115) de 8 a 10anos (412) mais de 10 anos.

10A- Se mais de 10 anos: Sentiu mudanças na cidade?

(261) Urbanização da orla (098) Coqueiros/ciclovia (017) Mais Segurança

(032) Praias mais limpas (004) Não opinou 
11- $O$ que acha da infra-estrutura da cidade de Praia Grande hoje?

(841) Ótima (670) Boa (114) Regular (025) Ruim

11A- Na sua opinião, o que deve ser melhorado?

(571) Abastecimento de água (041) Saúde (475)Segurança (498) Transito/faróis na saída da cidade com São Vicente (000) Energia eletrica (029) Esgoto (012) Arruamentos

(024) sinalizações (000) outros

12- Porque visita Praia Grande?

(274) Infra-estrutura (115) Qualidade da Praia (611) Lazer (650) Proximidade / Localização(000) Outros motivos. Quais

13- Com quem visita Praia Grande?

(902) Família (387) Amigos (147) Namorado(a) (053) Colegas Trabalho

(161) Colegas de faculdade (000) Outros

14-Quanto em média gasta por dia na cidade?

(189) Menos de $R \$ 50,00$ (763) de $R \$ 50,00$ a $R \$ 100,00$

(416) de $R \$ 100,00$ a $R \$ 200,00$ (282) mais de $R \$ 200,00$.

15- Quando vem a cidade costuma visitar os Shoppings de Praia Grande?

(1151)Sim. (499) Não.

Em caso afirmativo, por que vai ao Shopping?

(194) alimentação.(237) lazer / cinema(435) Lazer / cinema / alimentação

(230) compras (023) Paseeio (032) outros

16- Onde se alimenta quando visita a cidade?

(335) casa (254) restaurantes do centro (168) restaurantes próximos a residência

(893) Shopping (000) outros

17- $O$ que acha das mudanças urbanísticas da cidade de Praia Grande das últimas duas décadas para cá?

(1109) Ótima (441) Boa (098) Regular (002) Ruim

18- Acha da segurança em Praia Grande?

(283) Ótimo (811) Bom (392) Regular (164) Ruim

19- $O$ que acha da balneabilidade das praias?

(105) Ótima (542) Boa (796) Regular (207) Ruim

20- Se você fosse dar uma nota à sujeira nas praias durante o dia, qual nota daria? Quanto mais alta a nota, mais suja é a praia.

(013) Zero (056) de 1 a 2 (090) de 3 a 4 (501) de 5 a 6 (603) de 7 a 8 (387) de 9 a 10

20A- $O$ que acha da limpeza das praias?

(069) Ótima (601) Boa (743) Regular (237) Ruim

21- 0 que acha da limpeza das ruas e da cidade em geral?

(029) Ótima (369) Boa (814) Regular (438) Ruim

\section{Muito Obrigado!}

